\title{
Meliolales of INDiA - Volume III
}

\author{
V.B. Hosagoudar
}
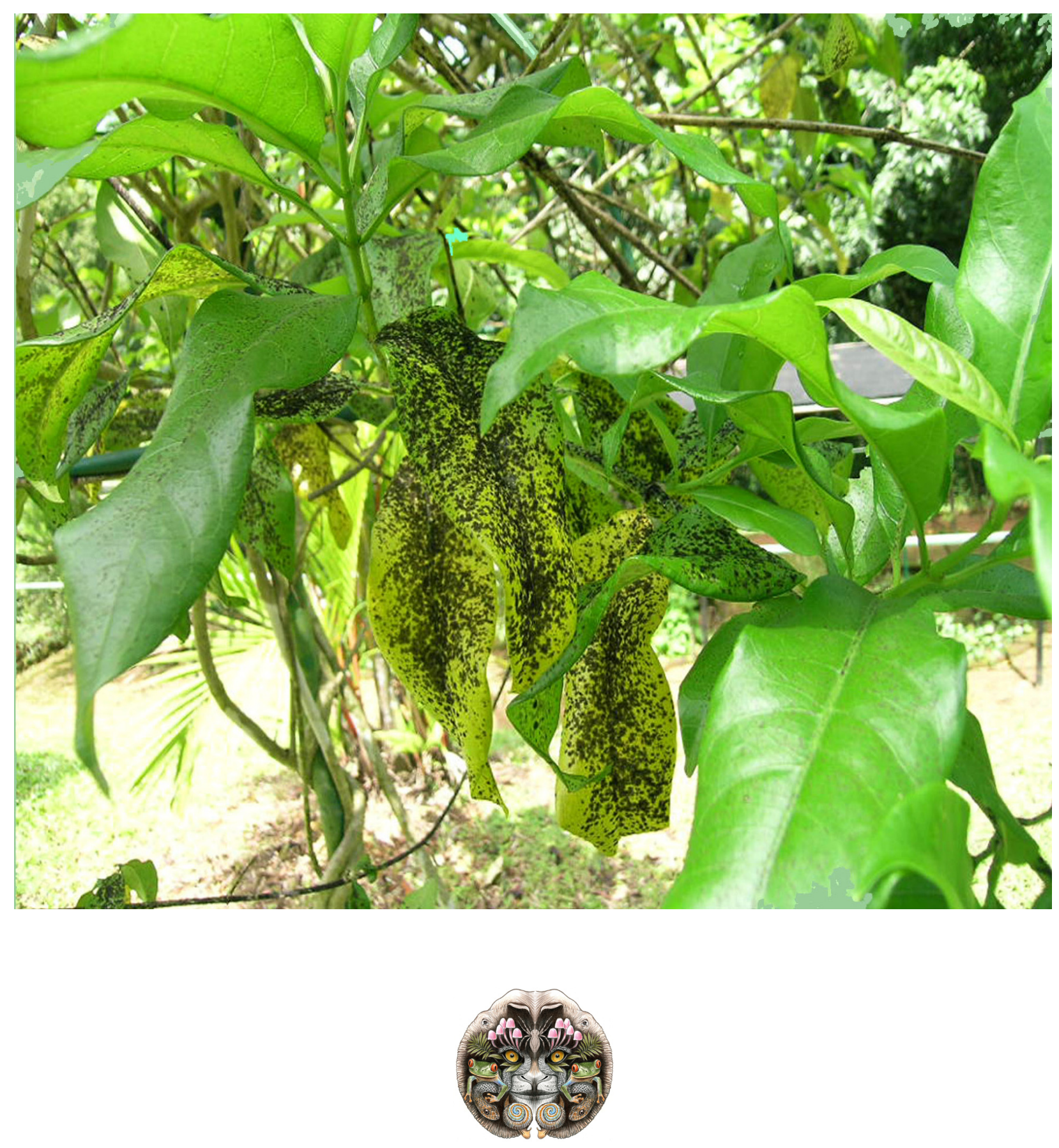

Journal of Threatened Taxa

April 2013 | Vol. 5 | No. 6 | Pages: 3993-4068 | Date of Publication: 08 April 2013 


\section{CONTENTS}

INTRODUCTION




\title{
MELIOLALES OF INDIA - VolUME III
}

\section{V.B. Hosagoudar}

Jawaharlal Nehru Tropical Botanic Garden and Research Institute, Palode, Thiruvananthapuram, Kerala, India vbhosagoudar@rediffmail.com

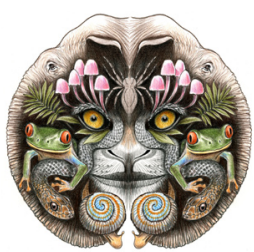

ISSN

Online 0974-7907 Print 0974-7893

OPEN ACCESS

Abstract: This work, is the continuation of my preceding two works on Meliolales of India, gives an account of 123 fungal species belonging to five genera, Amazonia (3), Appendiculella (1), Asteridiella (22), Ectendomeliola (1), Irenopsis (8) and Meliola (88), infecting 120 host plants belonging to 49 families. Generic key, digital formula, synoptic key to the species is provided. In the key, all the species are arranged under their alphabetically arranged host families. Description of the individual species is provided with the citation, detailed description, materials examined and their details including their herbarium details. Each species is supplemented with line drawings. Host and the species index is provided at the end. This work includes five new species: Meliola arippaensis, M. calycopteridis, M. cariappae, M. harpullicola and M. mutabilidis; a new variety: Irenopsis hiptages Yamam. var. indica and two new names: Asteridiella micheliifolia (based on A. micheliae) and Meliola strombosiicola (based on Meliola strombosiae)

Keywords: Amazonia, Appendiculella , Asteridiella, Ectendomeliola, India, Irenopsis, Meliola, Meliolales.

\begin{abstract}
Malayalam Abstract:

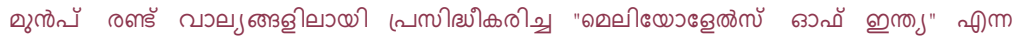

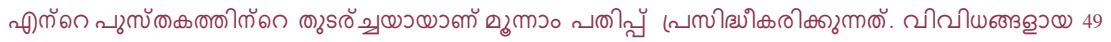

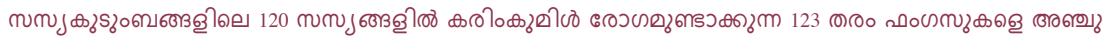

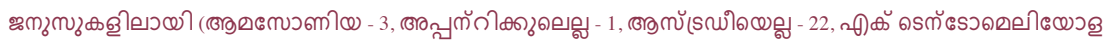

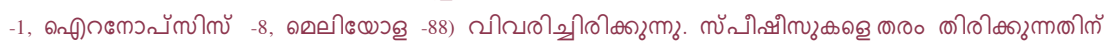

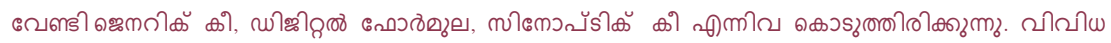

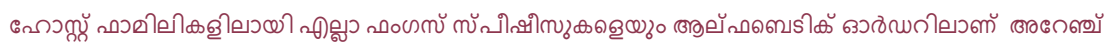

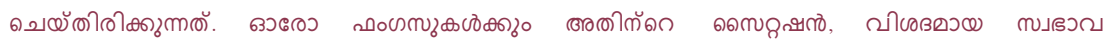

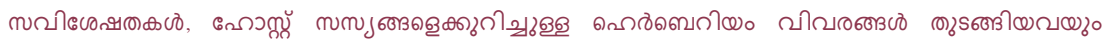

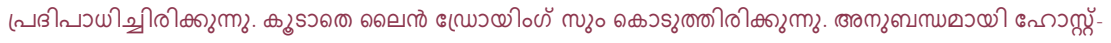

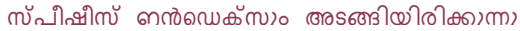

DOI: http://dx.doi.org/10.11609/JoTT.03307.3993-4068

Editor: H.C. Nagaveni, Indian Wood Science and Technology, Bengaluru, India

Date of publication: 08 April 2013 (online \& print)

Manuscript details: Ms \# 03307 | Received 16 August 2012 | Final received 08 December 2012 | Finally accepted 21 January 2013

Citation: Hosagoudar, V.B. (2013). Meliolales of India - Volume III. Journal of Threatened Taxa 5(6): 3993-4068; doi:10.11609/JoTT.o3307.3993-4068

Copyright: (C) Hosagoudar 2013. Creative Commons Attribution 3.0 Unported License. JoTT allows unrestricted use of this article in any medium for non-profit purposes, reproduction and distribution by providing adequate credit to the authors and the source of publication.

Funding: Jawaharlal Nehru Tropical Botanic Garden and Research Institute, Palode, Thiruvananthapuram, Kerala, India

Competing Interest: None

Acknowledgements: Thanks are due to Dr. P.G. Latha, Director, Jawaharlal Nehru Tropical Botanic Garden and Research Institute, Palode, Thiruvananthapuram, Kerala, India (JNTBGRI), Palode for providing the facility.

Author Details: DR. V.B. HOAGOUDAR is a Senior Scientist in JNTBGRI, has been working on foliicolous fungi since 1974 , published 16 books and more than 400 research papers mostly on foliicolous fungi; and has proposed three new families, 17 genera and more than 800 species and infra specific taxa. 


\section{INTRODUCTION}

The study of the meliolaceous fungi in the Western Ghats of peninsular India has taken a momentum in taxonomic account but the thorough knowledge and their systematic study of all the forest areas in the biodiversity rich areas like Western Ghats, Eastern Ghats, northeastern India is lacking. The systematic study of these fungi from the Andaman Islands is yet to be started. The present work is the third Indian monographic work in addition to my first and second volumes (Hosagoudar $1996,2008)$. The present work is mainly concentrated on the additional taxa to the preceding work. To facilitate the generic identity, key has been provided.

\section{KEY TO THE GENERA}

1. Perithecia flattened-globose in the radiating hyphae

Amazonia

1. Perithecia globose

Ectendomeliola

2. Mycelium partly endophytic

2. Mycelium ectophytic only Irenopsis

3. Perithecial setae present

3. Perithecial setae absent

4. Mycelial setae present Meliola

4. Mycelial setae absent Asteridiella

\section{DIGITAL FORMULA}

Beeli formula consists of 8 digits. The first 4 digits before the stop (left side to the stop) represent the morphological characters like ascospore septation, presence or absence and the nature of the perithecial setae or appendages, presence or absence and the nature of the mycelial setae and the arrangements of appressoria, respectively. The second 4 digits, after the stop, represent the measurements such as length and breadth of ascospores, diameter of perithecia and length of mycelial setae, respectively. The species having both simple \& dentate setae is denoted by $1 / 3$, while species having straight and uncinate setae are designated as $1 / 2$. The Beeli formula is modified here to accommodate the genus Armatella having 1-2 septate ascospores. Further, for Prataprajella, the second digit becomes $3 / 4$ or so.
I. MORPHOLOGY (first four digits from left)

\section{Normal septation of ascospores}

1. 1-septate

2. 3-septate

3. 4-septate

2. Perithecia

1. Without setae or appendages

2. With larviform, horizontally striated append ages

3. With uncinate or coiled setae

4. With straight setae

3. Mycelial setae (often on perithecia and from subiculam)

0. Absent

1. Simple

2. Simple, entire, uncinate or coiled

3. Dentate or shortly furcate (up to $30 \mu \mathrm{m}$ )

4. Branched (branches more than $30 \mu \mathrm{m}$ )

\section{Appressoria}

1. Alternate or unilateral (less than $1 \%$ opposite)

2. Regularly opposite

3. Both opposite and alternate

II. Measurements (second four digits from the full stop)

5. Maximum ascospore length

1. Below $20 \mu \mathrm{m}$

2. $21-30 \mu \mathrm{m}$

3. $31-40 \mu \mathrm{m}$

4. $41-50 \mu \mathrm{m}$

5. $51-60 \mu \mathrm{m}$

6. More than $60 \mu \mathrm{m}$ long

6. Maximum ascospore width

1. Up to $10 \mu \mathrm{m}$

2. $11-20 \mu \mathrm{m}$

3. $21-30 \mu \mathrm{m}$

4. More than $30 \mu \mathrm{m}$

7. Maximum diameter of perithecia

1. Up to $100 \mu \mathrm{m}$

2. $101-200 \mu \mathrm{m}$

3. $201-300 \mu \mathrm{m}$

4. More than $301 \mu \mathrm{m}$

8. Maximum length of mycelial setae

1. Up to $300 \mu \mathrm{m}$

2. $301-500 \mu \mathrm{m}$

3. $501-1000 \mu \mathrm{m}$

4. More than $1000 \mu \mathrm{m}$

0. Absent. 
The treatment of species and varieties consists of the original citation of the correct name, citation of the world monograph and Indian monograph, relevant synonyms (if any) based on the monographs Hansford (1961) and Hosagoudar (1996). The citation is followed by the description based on the present collections, which are deposited in JNTBGRI (Jawaharlal Nehru Tropical Botanic Garden and Research Institute, Thiruvananthapuram) and $\mathrm{HClO}$ (Herbarium Cryptogamae Indiae Orientalis), New Delhi and few are at ILLS (Illinois Natural History Survey, Illinois, USA). At the end of the description of each taxon, notes have been provided regarding their identification and distribution. Line drawings have been provided to most of the studied taxa.

\section{DESCRIPTION OF SPECIES}

\section{THE GENUS AMAZONIA}

Amazonia dikesinghii Hosag., Jacob Thomas \& Agarwal, Nelumbo 52: 1, 2010. (Image 1, Fig. 1)

Colonies epiphyllous, dense, up to $3 \mathrm{~mm}$ in diameter, scattered. Hyphae substraight to flexuous, branching
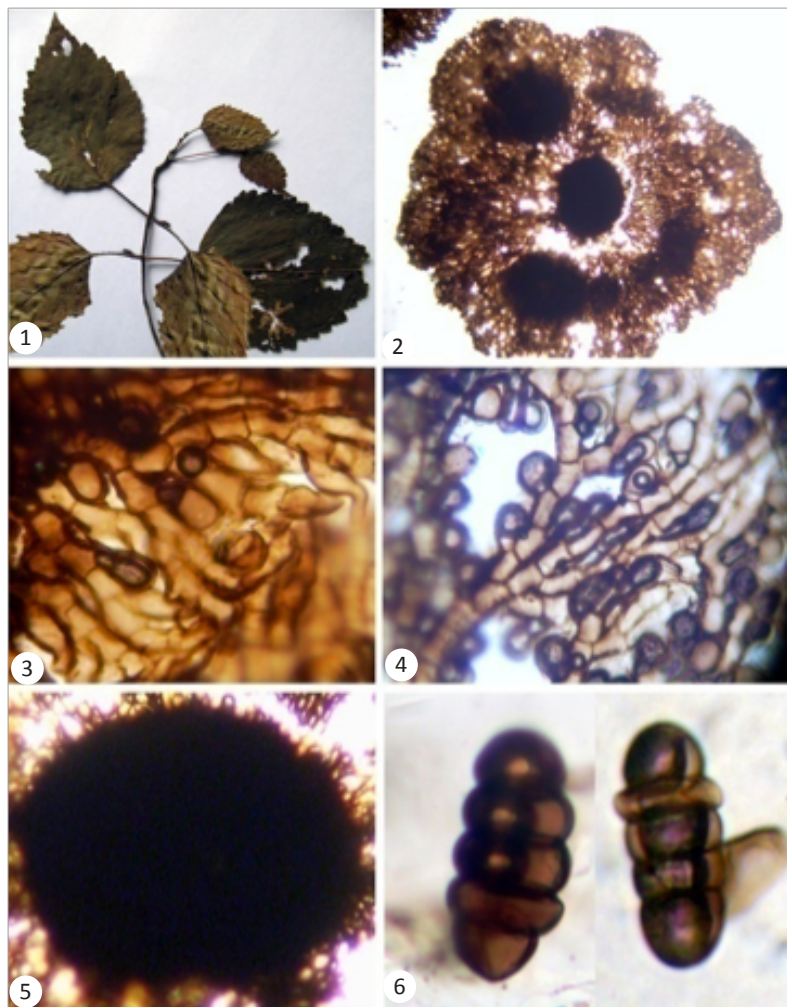

Image 1. Amazonia dikesinghii

1 - Infected leaves; 2 - Colony with perithecia; 3-4 - Appressoriate mycelium; 5 - Perithecium; 6 - Ascospores

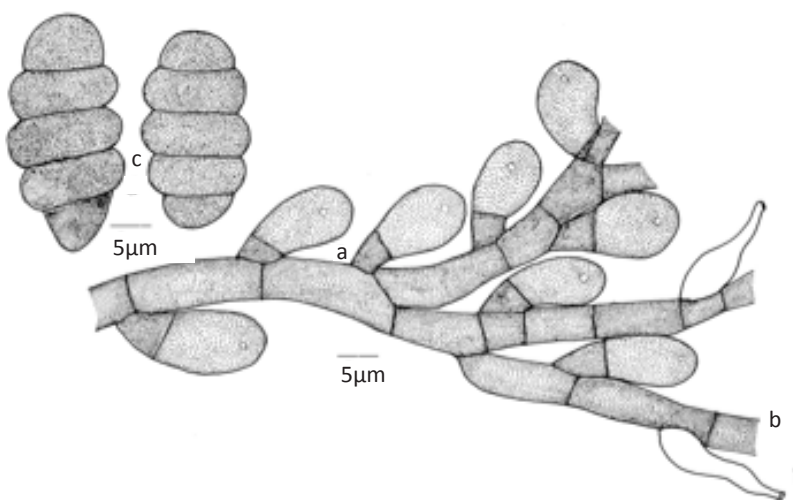

Figure 1. Amazonia dikesinghii

a - Appressorium; b - Phialide; c - Ascospores

alternate to rarely opposite at acute angles, very closely reticulate to form a solid mycelial mat, cells $6-13 \times 6-$ $8 \mu \mathrm{m}$. Appressoria alternate to unilateral, straight to curved, antrorse to closely antrorse and often appressed to the hyphae, 12-17 $\mu \mathrm{m}$ long; stalk cells cylindrical to cuneate, 3-5 $\mu \mathrm{m}$ long; head cells ovate to globose, entire, 12-16x11-16 $\mu \mathrm{m}$. Phialides born on a separate mycelial branches, alternate to opposite, conoid to ampulliform, 8-11x6-8 $\mu \mathrm{m}$. Perithecia flattened-globose, up to $200 \mu \mathrm{m}$ in diameter; ascospores oblong to ellipsoidal, 4-septate, constricted at the septa, 35-40×12-18 $\mu \mathrm{m}$.

Materials examined: HCIO 49045 (holotype), TBGT 3311 (isotype), 02.ii.2008, Kerala, Thiruvananthapuram, Peppara Wildlife Sanctuary, Athirumala, on leaves of Pogostemon travancoricus Bedd. (Lamiaceae), Jacob Thomas; HClO 49045, TBGT 3300, 02.iii.2008, Thiruvananthapuram, Neyyar Wildlife Sanctuary, Pongalappara, Jacob Thomas. This is the only species of the genus Amazonia on the members of Lamiaceae (Hansford 1961; Hu et al. 1996, 1999; Hosagoudar 1996,

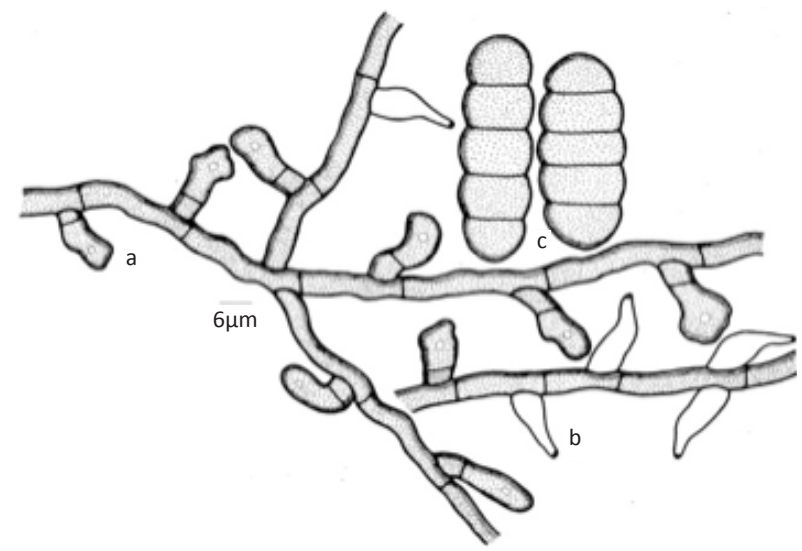

Figure 2. Amazonia elaeocarpi

aa - Appressorium; b - Phialide; c - Ascospores 
2008; Hosagoudar et al. 1997; Hosagoudar \& Agarwal 2008).

Amazonia elaeocarpi Hosag., Agarwal, H. Biju \& Archana,Indian Phytopathol. 60: 82, 2007 (Fig. 2)

Colonies amphigenous, thin, up to $2 \mathrm{~mm}$ in diameter. Hyphae straight to flexuous, branching alternate to opposite at acute to wide angles, loosely reticulate, cells $13-35 \times 4-8 \mu \mathrm{m}$. Appressoria alternate, unilateral, antrorse to retrorse, straight to curved, 11-24 $\mu \mathrm{m}$ long; stalk cells cylindrical to cuneate, 3-10 $\mu \mathrm{m}$ long; head cells ovate, oblong, cylindrical, straight to curved, entire to angular, broadly rounded to truncate at the apex, 8-16x6-11 $\mu \mathrm{m}$. Phialides mixed with appressoria, alternate, opposite to unilateral, 9-26x-6-10 $\mu \mathrm{m}$. Perithecia flattened-globose, scattered, up to $130 \mu \mathrm{m}$ in diameter; ascospores obovoidal, 4-septate, constricted at the septa, 41-48x14-19 $\mu \mathrm{m}$.

Material examined: HClO 46372 (holotype), TBGT 2018 (isotype), 12.xii.2003, Kerala, Palakkad, Silent Valley, Sairandhri, on leaves of Elaeocarpus munronii (Wight) Mast. (Elaeocarpaceae), V.B. Hosagoudar et al.

This species differs from Asteridiella elaeocarpicola Hansf., A. elaeocarpi-tuberculati Hosag. and Meliola elaeocarpi Yates in absence of mycelial setae and having flattened-globose perithecia (Hansford 1961; Hosagoudar 1996).

Amazonia palaquii Hosag. \& Robin, Bioscience Discovery 2(2): 264, 2011. (Fig. 3)

Colonies hypophyllous, crustose, up to $4 \mathrm{~mm}$ in diameter, confluent. Hyphae substraight, branching opposite at acute angles, loosely to closely reticulate, cells $13-22 \times 5-7 \mu \mathrm{m}$. Appressoria alternate to unilataral, antrorse, straight to slightly curved, 13-17 $\mu \mathrm{m}$ long; stalk cells cuneate, 2-5 $\mu \mathrm{m}$ long; head cells globose, ovate, entire, 9-13x7-10 $\mu \mathrm{m}$. Phialides few, mixed with appressoria, alternate, ampulliform, 13-20x7-9 $\mu \mathrm{m}$. Perithecia mostly aggregated, flattened-globose, up to $220 \mu \mathrm{m}$ in diam.; ascospores ellipsoidal, 4-septate, constricted at the septa, 33-44×16-20 $\mu \mathrm{m}$.

Material examined: TBGT 4651(holotype), HCIO 50734 (isotype), 18.i.2007, Kerala, Pathanamthitta, Gavi, on leaves of Palaquium sp. (Sapotaceae), Gireesh Kumar et al.

Amazonia sideroxyli Hansf. is the only species of the genus Amazonia known on Sideroxylon sp. from Malaysia (Hansford 1961). Three species of the genus Palaquium are known from Kerala and all are endemic to the region (Nayar et al. 2006). The present species differs from $A$. sideroxyli Hansf. in having loosely reticulate hypophyllous colonies with straight to substraight mycelia in contrast to colonies forming solid mycelial mat and the hyphae straight to substraight.

\section{THE GENUS APPENDICULELLA}

Appendiculella elaeocarpi Hosag. \& Robin, J. Threatened Taxa 3(5): 1782, 2011. (Fig. 4)

Colonies epiphyllous, subdense, up to $3 \mathrm{~mm}$ in diameter. Hyphae straight to undulate, branching mostly opposite at acute to wide angles, loosely to closely reticulate, cells $22-29 \times 3-5 \mu \mathrm{m}$. Appressoria alternate, antrorse to subantrorse, 17-19 $\mu \mathrm{m}$ long; stalk

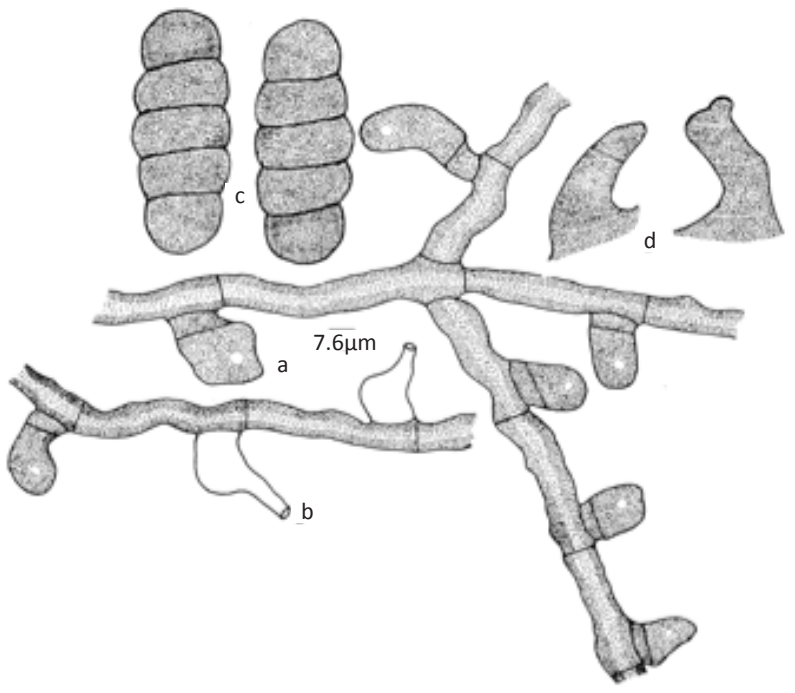

Figure 4. Appendiculella elaeocarpi

a - Appressorium; b - Phialide; c - Ascospores; $d$ - Perithecial appendages 
cells cylindrical to cuneate, 5-7 $\mu \mathrm{m}$ long; head cells globose, ovate, entire, 12-14x7-10 $\mu \mathrm{m}$. Phialides mixed with appressoria, alternate to opposite, ampulliform, 14-22x7-10 $\mu \mathrm{m}$. Perithecia scattered, globose, up to $106 \mu \mathrm{m}$ in diameter; perithecial appendages conoid, straight to curved, horizontally striated, attenuated to broadly rounded at the apex, up to $24 \mu \mathrm{m}$ long; ascospores oblong to ellipsoidal, 4-septate, constricted at the septa, 34-38x12-14 $\mathrm{mm}$.

Materials examined: $\mathrm{HClO} 48808$ (holotype), TBGT 3184 (isotype), 04.iii.2007, Kerala, Kottayam, Ponthanpuzha, Chapathu, on leaves of Elaeocarpus tuberculatus Roxb. (Elaeocarpaceae), P.J. Robin.

Asteridiella elaeocarpi-tuberculati Hosag., A. elaeocarpicola Hansf. and Meliola elaeocarpi Yates are known on this host genus (Hansford 1961; Hosagoudar et al. 1997; Hosagoudar 1996, 2008; Hosagoudar \& Agarwal 2008). The present taxon differs from all in

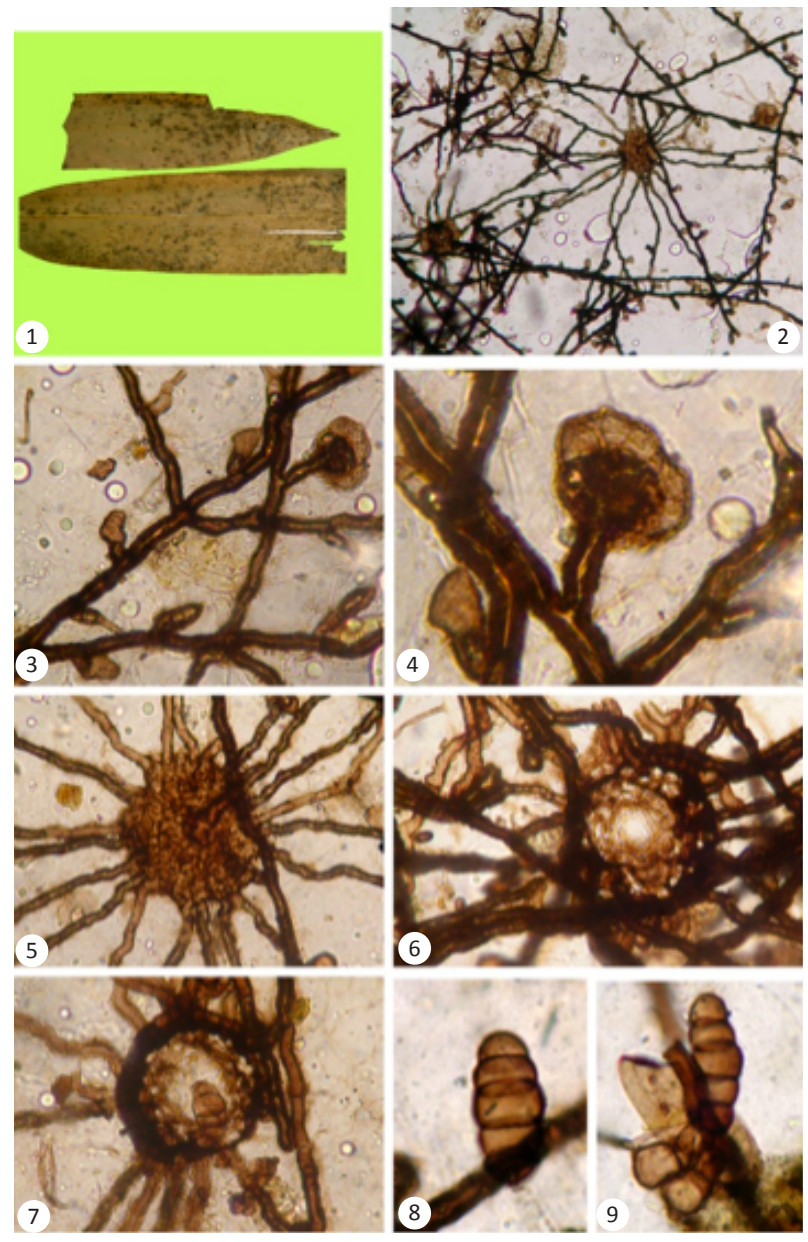

Image 2. Asteridiella amomi

1 - Infected leaves; 2 - Colony with perithecia; 3 - Appressoriate mycelium; 4-7- Developing perithecium; 8-9- Ascospores having perithecial appendages and is the first species of the genus Appendiculella known on the members of the family Elaeocarpaceae.

\section{THE GENUS ASTERIDIELLA}

Asteridiella amomi Hosag., Jacob Thomas \& Agarwal, Nelumbo 52: 1, 2010. (Image 2, fig 5).

Colonies amphigenous, dense, subvelvety, up to $4 \mathrm{~mm}$ in diameter, confluent. Hyphae substraight to slightly crooked, branching opposite to irregular at acute to wide angles, loosely reticulate, cells $19-36 \times 7-10$ $\mu \mathrm{m}$. Appressoria alternate and unilateral, straight to curved, antrorse to spreading, 21-29 $\mu \mathrm{m}$ long; stalk cells cylindrical to cuneate, 9-12 $\mu \mathrm{m}$ long; head cells ovate, globose, angular to sublobate, 12-18x9-15 $\mu \mathrm{m}$. Phialides mixed with appressoria, alternate to opposite, ampulliform, 19-26x4-7 $\mu \mathrm{m}$. Perithecia scattered, up to $100 \mu \mathrm{m}$ in diameter; perithecial cells conoid to mammiform, 9-14x9-12 $\mu \mathrm{m}$; ascospores ellipsoidal, 4septate, constricted at the septa, 36-41x14-17 $\mu \mathrm{m}$.

Materials examined: HCIO 48833 (holotype), TBGT 3209 (isotype), 04.iii.2008, Kerala, Thiruvananthapuram, Peppara Wildlife Sanctuary, Athirumala, on leaves of Amomum subulatum Roxb. (Zingiberaceae), Jacob Thomas et al.; HClO 48834, TBGT 3210, 04.iii.2008, Thiruvananthapuram, Neyyar Wildlife Sanctuary, Kombe, Jacob Thomas et al.

Two species of the genus Asteridiella, namely, A. costi (Stev.) Hansf. and A. parasitica (Stev.) Hansf. are known on Costus sp. from Panama and Ecuador, respectively. However, Asteridiella amomi differs from

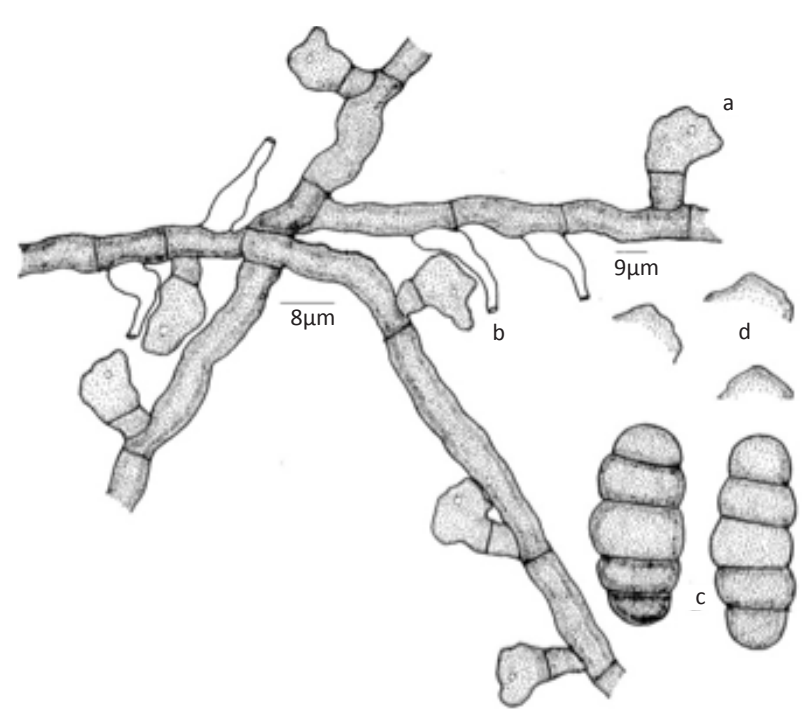

Figure 5. Asteridiella amomi

a - Appressorium; b - Phialide; c - Ascospores; $d$ - Perithecial wall cells 
both the species in having broader mycelial cells, longer appressoria with entire to lobate head cells. Further, this forms the first meliolaceous fungus on the genus Amomum (Hansford 1961).

Asteridiella anacolosae Hosag., Sabeena \& Jacob Thomas, Bioscience Discovery 2: 17, 2011. (Fig. 6)

Colonies mostly hypophyllous, thin, up to $2 \mathrm{~mm}$ in diameter, confluent. Hyphae substraight, branching opposite to unilateral at acute to wide angles, loosely reticulate, cells $12-25 \times 7-10 \mu \mathrm{m}$. Appressoria alternate to unilateral, closely arranged, antrorse, subantrorse to retrorse, 12-15 $\mu \mathrm{m}$ long; stalk cells cylindrical to cuneate, 2-7 $\mu \mathrm{m}$ long; head cells oblong, ovate, globose, entire, angular to sublobate, attenuated towards the tip, 10-17x7-15 $\mu \mathrm{m}$. Phialides mixed with appressoria, ampulliform, 15-20x7-10 $\mu \mathrm{m}$. Perithecia scattered, up to $100 \mu \mathrm{m}$ in diam., perithecial wall cells conoid, up to $15 \mu \mathrm{m}$ long; ascospores cylindrical, 4-septate, constricted at the septa, $37-45 \times 17-20 \mu \mathrm{m}$.

Material examined: TBGT 4554 (holotype). HCIO 50637 (isotype), 14.iii.2007, Kerala, Pathanamthitta, Sabrimala, on leaves of Anacolosa sp. (Olacaceae), Jacob Thomas et al.

Three species of the genus Asteridiella are known on the members of the family Olacaceae, namely, $A$. ximeniae (Bat. \& Silva) Hansf., A. scordocarpi Hansf. \& A. strombosiae Hansf. Of these, the former two species are similar to the present species in having 3-septate

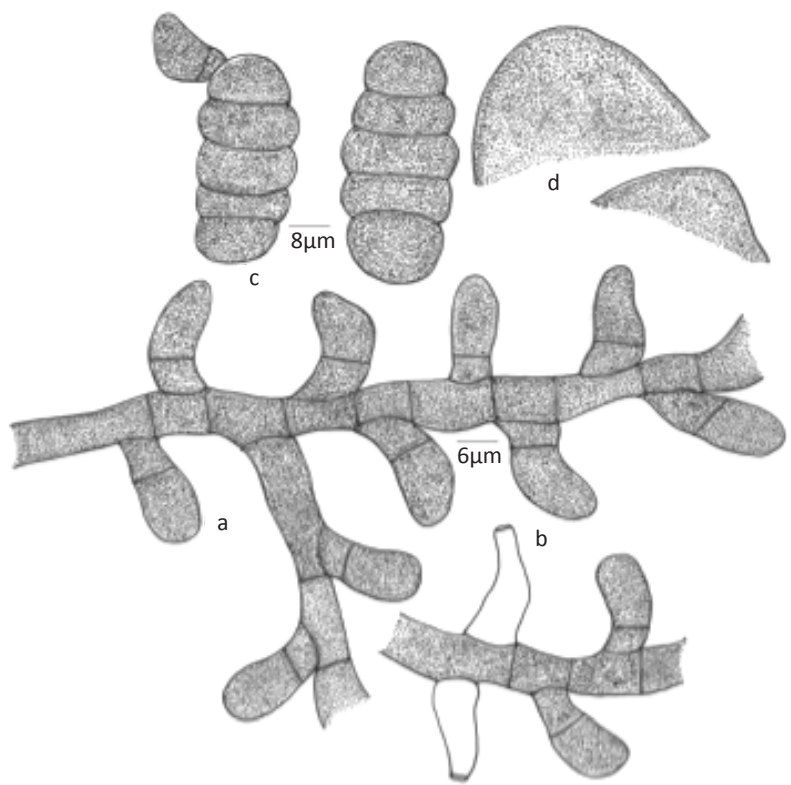

Figure 6. Asteridiella anacolosae

a - Appressorium; b - Phialide; c - Ascospores; $d$ - Perithecial wall cells ascospores but differs from both in having ovate, oblong to cylindrical head cells attenuated towards the apex in contrast to globose cells (Hansford 1961).

Asteridiella brahmagiriensis Hosag., Archana. \& Agarwal, Indian Phytopath. 60: 237, 2007. (Fig. 7)

Colonies amphigenous, subdense, up to $2 \mathrm{~mm}$ in diameter, confluent. Hyphae substraight to flexuous, branching opposite to irregular at acute to wide angles, cells $14-38 \times 4-7 \mu \mathrm{m}$. Appressoria alternate to unilateral, antrorse to subantrorse, straight to slightly curved, 9-27 $\mu \mathrm{m}$ long; stalk cells cylindrical to cuneate, 3-8 $\mu \mathrm{m}$ long; head cells oblong, ovate, globose, entire, 6-19x6$11 \mu \mathrm{m}$. Phialides mixed with appressoria, opposite to alternate, ampulliform, 11-24x4-8 $\mu \mathrm{m}$. Perithecia globose, scattered to grouped, up to $284 \mu \mathrm{m}$ in diameter; perithecial wall cells conoid to mammiform, up to $35 \mu \mathrm{m}$ long; ascospores obovoidal, 4-septate, constricted at the septa, 36-43x14-19 $\mu \mathrm{m}$.

Material examined: $\mathrm{HClO} 46967$ (holotype), TBGT 2184 (isotype), 13.xi.2003, Karnataka, Coorg, Talacauveri, Brahmagiri, MPCA, on leaves of Syzygium sp. (Myrtaceae), V.B.Hosagoudar et al.

Based on the Beeli formula, this species is closer to Asteridiella zeheri (Doidge) Hansf. known on Eugenia zeheri from South Africa (Hansford 1961) but differs from it in having entire margin of the head cells of appressoria in contrast to angular to lobate. Asteridiella eugeniaefruticosae Jana et al. is known on Eugenia fruticosa from Nagaland (Jana et al. 2005). However, A. brahmagiriensis differs from it in having longer appressoria (10-27 $\mu \mathrm{m}$ against 12-17 $\mu \mathrm{m}$ ), head cells entire in contrast to angular, larger perithecia ( $284 \mu \mathrm{m}$ vs. $105 \mu \mathrm{m})$ and having

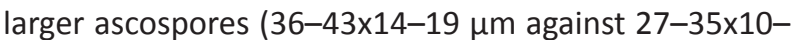

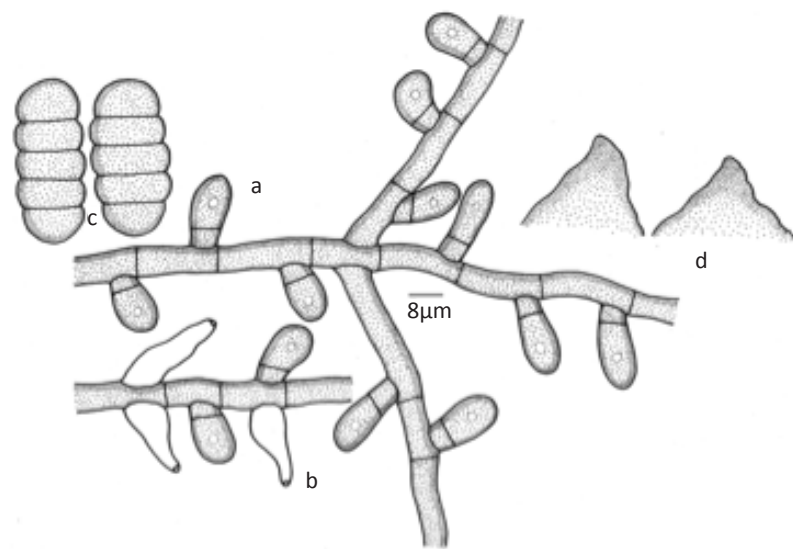

Figure 7. Asteridiella brahmagiriensis

a - Appressorium; b - Phialide; c - Ascospores; d - Perithecial wall cells 
$16 \mu \mathrm{m})$.

Asteridiella chowrirae Hosag., Thimmaiah \& Jayashankara, Mycosphere 2(6), 611, 2011. (Image. 3).

Colonies epiphyllous, dense, up to $3 \mathrm{~mm}$ in diameter. Hyphae substraight to flexuous, branching alternate to opposite at acute to wide angles, loosely reticulate, cells $23-25 \times 6-8 \mu \mathrm{m}$. Appressoria alternate, antrorse, subantrorse to reflexed, straight to variously curved, 22$30(-48) \mu \mathrm{m}$ long; stalk cells cylindrical to cuneate, rarely up to 2-septate, 6-12(-20) $\mu \mathrm{m}$ long; head cells ovate, globose, cylindrical, entire, angular to rarely sublobate, very few attenuated at the apex, 16-23 x 12-20 $\mu \mathrm{m}$. Phialides numerous, apparently borne on a separate mycelium but mixed with appressoria, alternate to opposite, ampulliform, 15-30 x 5-8 $\mu \mathrm{m}$. Perithecia scattered, up to $120 \mu \mathrm{m}$ in diam.; perithecial wall cells conoid, projected, attenuated at the apex, up to $20 \mu \mathrm{m}$ high; ascospores straight to slightly curved, oblong to cylindrical, 4-septate, constricted at the septa, $42-45 \times$ 16-18 $\mu \mathrm{m}$.

Material examined: TBGT 5708 (holotype), 29.xi.2009, Karnataka, Kodagu, Hoddur, Chowrira House, on leaves of Euphorbia pulcherrima Willd. ex Klotz.

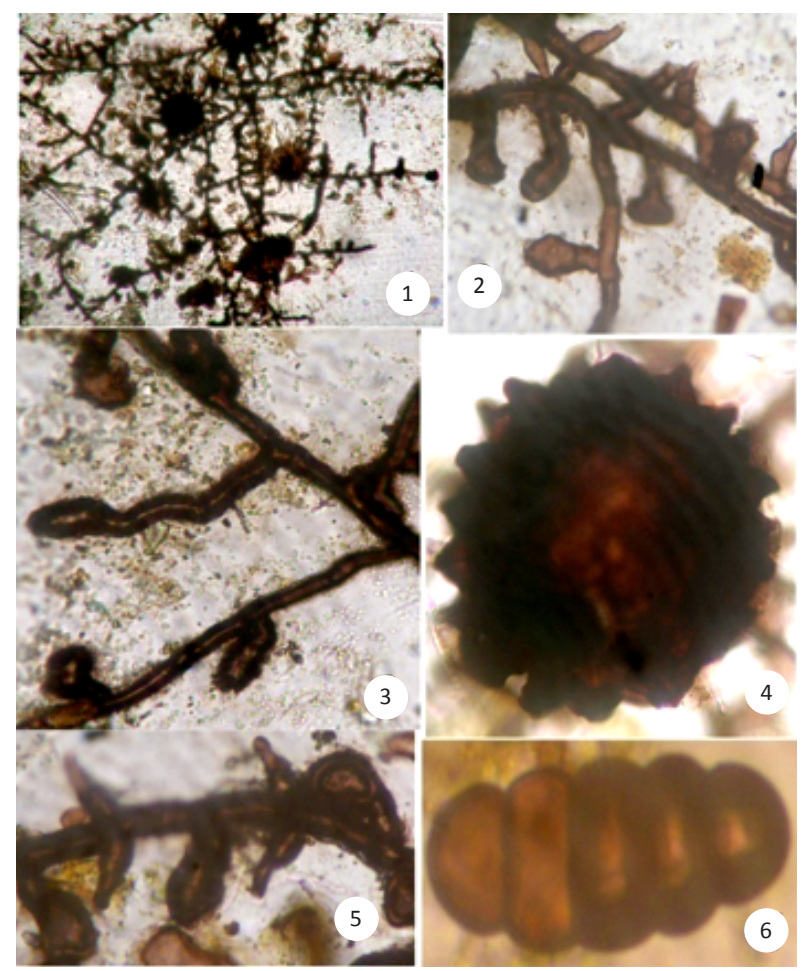

Image 3. Asteridiella chowrirae

1- Fungal colony; 2 - Appressorial mycelium; 3 - Elongated basal cell of the appressorium; 4 - Perithecium with perithecial wall cells; 5 Phialides mixed with appressoria; 6 - Ascospore; Bars $=24 \mu \mathrm{m}$
(Poinsettia pulcherima Graham) (Euphorbiaceae), C. Jagath Thimmaiah.

Asteridiella antidesmatis Hansf., A. cleistanthi Hansf., A. drypeticola Hansf., A. malloticola Yamam., A. sapii Hansf. \& A. subapoda Sydow have the same digital formula 3101.4220. Of these, it is similar to $A$. sapi Sydow in having entire to sublobate head cells of the appressoria but differs from it in having longer and often septate stalk cells of the appressoria and the head cells are entire, angular to sublobate (Hansford 1961).

Asteridiella crotonis-caudati Hosag., Riju \& Agarwal, Indian Phytopath. 63: 76, 2010. (Fig. 8).

Colonies amphigenous, thin, scattered, up to $6 \mathrm{~mm}$ in diameter. Hyphae straight to flexuous, branching alternate, opposite, unilateral at acute to wide angles, loosely to closely reticulate, cells $17-40 \times 3-5 \mu \mathrm{m}$. Appressoria alternate, unilateral, antrorse, 13-21 $\mathrm{mm}$ long; stalk cells cylindrical to cuneate, $3-8 \mu \mathrm{m}$ long; head cells globose, ovate, entire, $8-13 \times 8-13 \mu \mathrm{m}$. Phialides mixed with appressoria, alternate to opposite, unilateral, ampulliform, 13-23x6-8 $\mu \mathrm{m}$. Perithecia scattered, up to $110 \mu \mathrm{m}$ in diameter; perithecial wall cells conoid to mammiform, up to $16 \mu \mathrm{m}$ long; ascospores cylindrical, 4-septate, constricted at the septa, 30-34×13-15 $\mu \mathrm{m}$.

Material examined: HCIO (holotype), TBGT 3436 (isotype), 3.viii.2008, Kerala, Palakkad, Silent Valley National Park, Thondakulam, on leaves of Croton caudatus Geisel. (Euphorbiaceae), M. C. Riju et al.; HCIO 50574, TBGT 4491, 04.viii.2008, M.C. Riju.

Based on the digital formula 3101.3220, this species

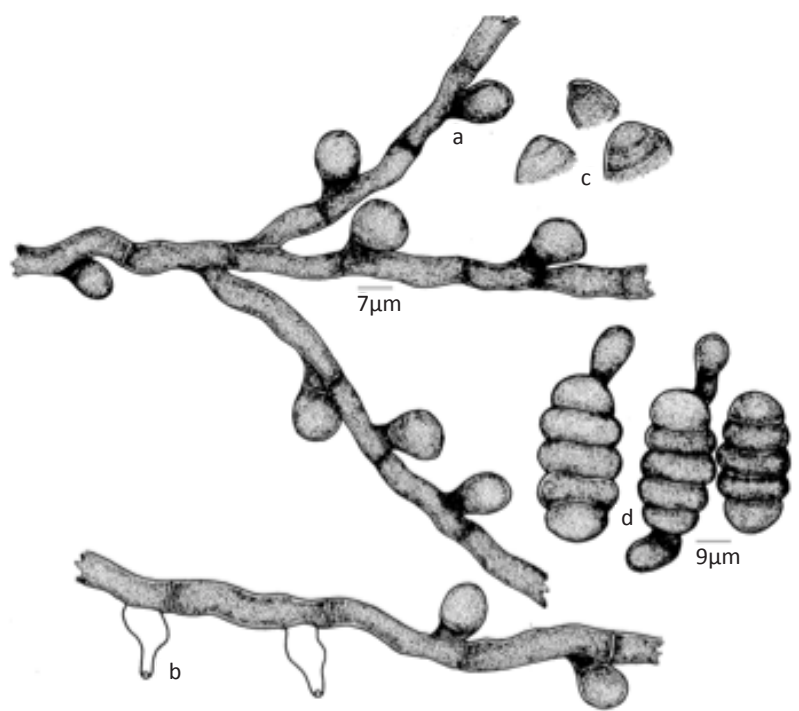

Figure 8. Asteridiella crotonis-caudat

a - Appressorium; b - Phialide; c - Perithecial wall cells; $d$ - Ascospores 
is similar to Asteridiella phyllanthi (Deight.) Hansf., $A$. erythrococcae Hansf., A. hansfordii (Stev.) Hansf. and A. hansfordii (Stev.) Hansf. var. densa (Hansf. \& Deight.) Hansf. However, differs from all in having entire head cells of appressoria. Based on the character of entire head cells of the appressoria, Asteridiella crotoniscaudati differs from $A$. phyllanthi in having longer and regularly antrorse appressoria; from $A$. macarangicola Hosag. in having straight to flexuous hyphae. Based on the host specificity, it differs from $A$. kombeensis Hosag., $A$. wyanadensis Hosag. et al. and $A$. crotonis Hosag. in having entire head cells of the appressoria (Hansford 1961; Hosagoudar 1996).

Asteridiella depokensis Hansf., Sydowia 10: 47, 1957; Sydowia Beih. 2: 688, 1961; Hosag., Timmaiah \& Jayashankara, Mycosphere 2(6), 612, 2011. (Image. 4)

Colonies epiphyllous, dense, up to $7 \mathrm{~mm}$ in diameter. Hyphae flexuous to crooked, branching alternate to opposite at acute to wide angles, closely reticulate, cells $12-17 \times 6-8 \mu \mathrm{m}$. Appressoria alternate, closely placed, antrorse to closely antrorse, often appressed to the hyphae, straight to curved, 14-24 $\mu \mathrm{m}$ long; stalk cells cylindrical to cuneate, 4-13 $\mu \mathrm{m}$ long; head cells globose, clavate, distinctly angular to truncate, rarely rounded, 9-16 x 12-18 $\mu \mathrm{m}$. Phialides many, mixed with appressoria, ampulliform, 16-20 x 6-7 $\mu \mathrm{m}$. Perithecia scattered, up to $130 \mu \mathrm{m}$ in diam.; perithecial cells mammiform, broadly rounded at the apex, up to $12 \mu \mathrm{m}$ long; ascospores oblong to cylindrical, 4-septate, constricted at the septa, 35-38x14-16 $\mu \mathrm{m}$.

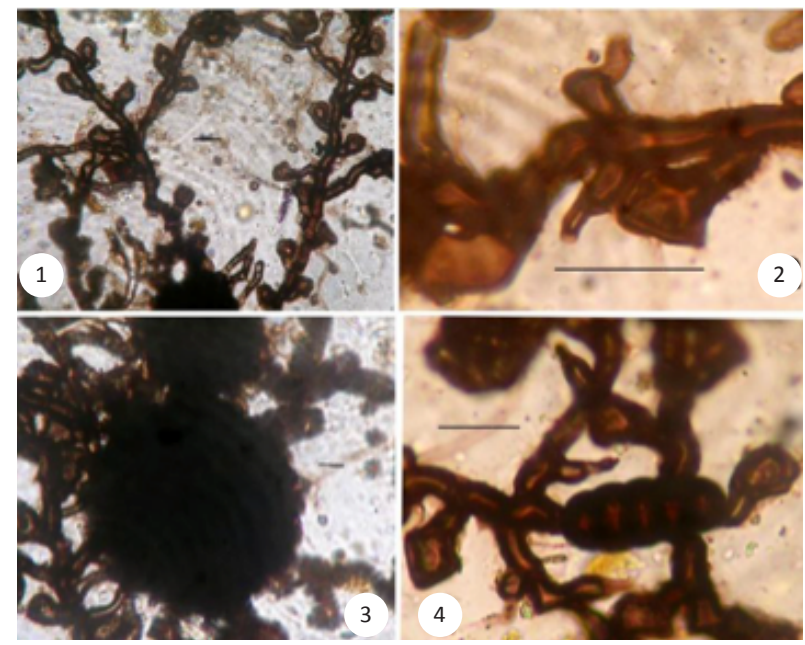

Image 4. Asteridiella depokensis

1 - Appressorium; 2 - Phialide; 3 - Ascospores; 4 - Perithecial wall cells; Bars $=8 \mu \mathrm{m}$
Material examined: TBGT 5698, 16.xi.2009, Karnataka, Kodagu, Hoddur, on leaves of Vitex negundo L. (Verbenaceae), C. Jagath Thimmaiah.

Angular head cells of the appressoria distinguish this species from others.

Asteridiella emciciana Hosag., Robin \& Archana, Sydowia 61(2): 244, 2009. (Fig. 9)

Colonies amphigenous, mostly epiphyllous, thin, up to $3 \mathrm{~mm}$ in diameter. Hyphae straight, substraight to slightly undulate, branching mostly opposite at acute angles, loosely to closely reticulate, cells 24-31 $\mu \mathrm{m}$ long. Appressoria alternate, unilateral, antrorse to subantrorse, 21-26 $\mu \mathrm{m}$ long; stalk cells cylindrical to cuneate, 7-9 $\mu \mathrm{m}$ long; head cells globose, ovate, oblong, entire, angular to slightly lobate, 12-17x10-12 $\mu \mathrm{m}$. Phialides mixed with appressoria, opposite, alternate to unilateral, ampliform, 14-19x5-7 $\mu \mathrm{m}$. Perithecia scattered, up to $110 \mu \mathrm{m}$ in diam.; ascospores oblong, ellipsoidal to cylindrical, 4-septate, constricted at the septa, 34-39x12-14 $\mu \mathrm{m}$.

Materials examined: HCIO 48442 (holotype), TBGT 3163 (isotype), 24.xii.2007, Tamil Nadu, Chennai, in the campus of Madras Christian College, on leaves of Scutia myrtiana (Burm.f.) Kurz (Rhamnaceae), V. B. Hosagoudar et al.

Asteridiella colubrinae (Stev.) Hansf. is known on Colubrina rufa from Panama, is the only species of the genus Asteridiella on Rhamnaceae (Hansford 1961; Hosagoudar 1996; Hosagoudar et al. 1997; Hosagoudar 2008; Hosagoudar \& Agarwal 2008). However, A.

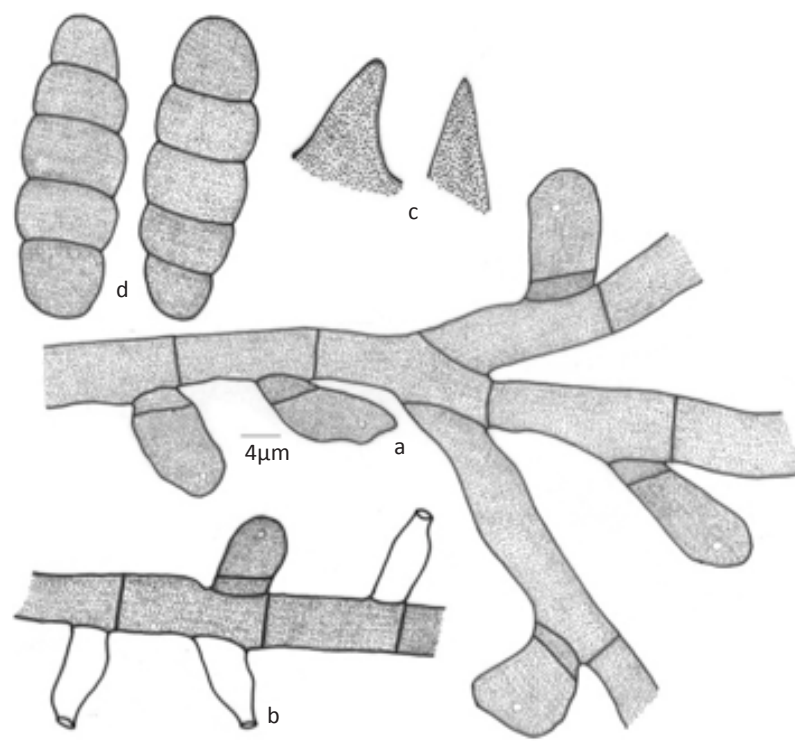

Figure 9. Asteridiella emciciana

a - Appressorium; b - Phialide; c - Perithecial wall cells; $d$ - Ascospores 
emciciana differs from it having straight hyphae with entire, angular to sublobate head cells of appressoria.

Asteridiella ficicola Hosag., Archana \& Sabu, J. Threatened Taxa 1(9): 474, 2009. (Fig. 10)

Colonies epiphyllous, dense, up to $2 \mathrm{~mm}$ in diameter, confluent. Hyphae straight, substraight to flexuous, branching mostly opposite to alternate at acute to wide angles, loosely to closely reticulate, cells $9-24 \times 6-8 \mu \mathrm{m}$. Appressoria alternate to unilateral, straight to slightly curved, antrorse to subantrorse, rarely retrorse, 12-21 $\mu \mathrm{m}$ long; stalk cells cylindrical to cuneate, $3.8 \mu \mathrm{m}$ long; head cells straight to slightly curved, globose, ovate, oblong, entire to rarely angular, $8-13 \times 6-10 \mu \mathrm{m}$. Phialides mixed with appressoria, opposite, alternate to unilateral, ampulliform, 12-19x6-10 $\mu \mathrm{m}$. Perithecia scattered to grouped, up to $160 \mu \mathrm{m}$ in diam., perithecial wall cells mammiform, up to $16 \mu \mathrm{m}$ long; ascospores obovoidal, 4-septate, constricted at the septa, 33-38x17-19 $\mu \mathrm{m}$.

Material examined: $\mathrm{HClO} 46806$ (holotype), TBGT 2147 (isotype) (MycoBank \# MB513420), 01.iv.2006, Kerala, Thiruvananthapuram, Palode, JNTBGRI Campus, Arboretum, on leaves of Ficus microcarpa L. (Moraceae), T. Sabu.

Based on the digital formula 3101.3220, this species is similar to Asteridiella olmediae Hansf. reported on Olmedia aspera from Panama. However, Asteridiella ficicola differs from it in having only epiphyllous and confluent colonies, shorter appressoria with mostly ovate to oblong head cells (Hansford 1961; Hosagoudar 1996).

In some perithecia, marginal cells were radiating and reminding of the genus Amazonia. However, most of the

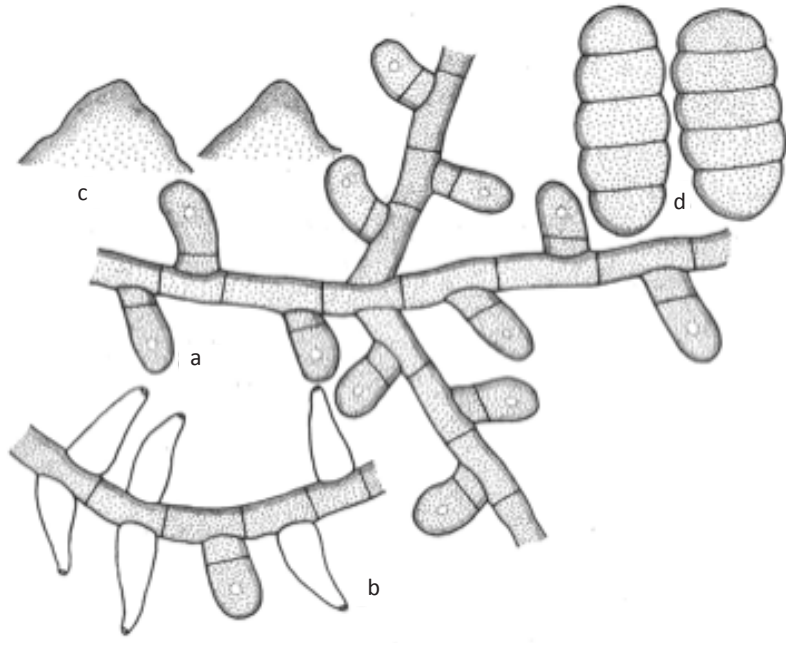

Figure 10. Asteridiella ficicola

a - Appressorium; b - Phialide; c - Perithecial wall cells; $d$ - Ascospores perithecia were globose so as to accommodate it in the genus Asteridiella.

Asteridiella homaligena Hosag., Thimmaiah \& Jayashankara, Mycosphere 2(6):613, 2012. (Image. 5)

Colonies amphigenous, mostly epiphyllous, subdense, up to $4 \mathrm{~mm}$ in diameter. Hyphae straight to substraight, branching alternate to opposite at acute to subacute angles, loosely reticulate, cells $17-25 \times 6-9 \mu \mathrm{m}$. Appressoria alternate, about 5\% opposite, antrorse to spreading, 16-25 $\mu \mathrm{m}$ long; stalk cells cylindrical to cuneate, 3-6 $\mu \mathrm{m}$ long; head cells ovate to obovate, entire to slightly angular, 14-20x11-15 $\mu \mathrm{m}$. Phialides mixed with appressoria, alternate to opposite, ampulliform, 21-27x4-9 $\mu \mathrm{m}$. Perithecia scattered, up to $130 \mu \mathrm{m}$ in diam., perithecial wall cells mammiform, up to $15 \mu \mathrm{m}$ high; ascospores obovoidal, oblong to cylindrical, 4-septate, constricted at the septa, 37-40×13-16 $\mu \mathrm{m}$.

Material examined: TBGT 5696 (holotype), 22.vii.2009, Karnataka, Kodagu, Hoddur, river side, on leaves of Homalium zeylanicum Benth. (Flacourtiaceae), C.Jagath Thimmaiah.

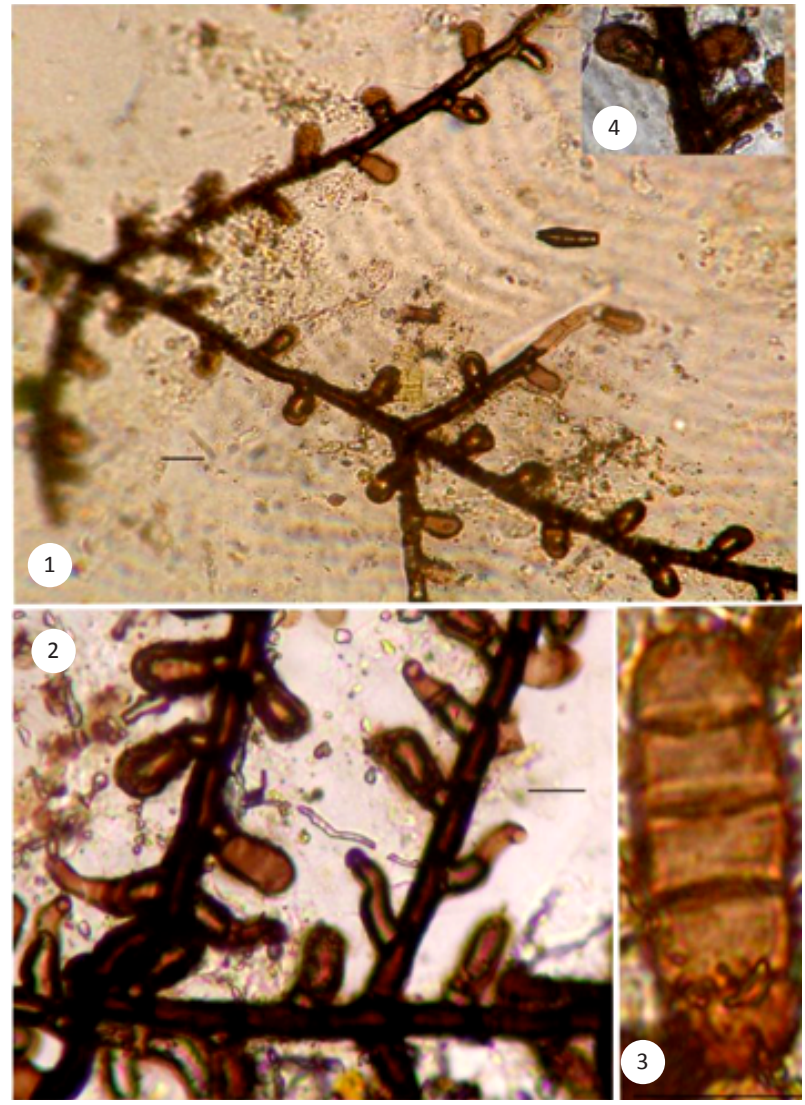

Image 5. Asteridiella homaligena

1 - Fungal colony; 2 - Phialides mixed with appressoria; 3 - Ascospore;

4 - Opposite appressoria; Bars $=12 \mu \mathrm{m}$ 
Asteridiella homalii-angustifolii (Deight.) Hansf. is known on Homalium angustifolium from Sierra Leone. However, the present species differs from it in having entire head cells of the appressoria in contrast to lobate ones (Hansford 1961, Hosagoudar 1996, 2008, Hu et al. 1996, 1999).

Asteridiella ixorae Hosag. \& Archana, J. Threatened Taxa 2: 889, 2010. (Fig. 11)

Colonies amphigenous, subdense, up to $2 \mathrm{~mm}$ in diameter, confluent. Hyphae straight to substraight, branching opposite at acute to wide angles, loosely to closely reticulate, cells $12-30 \times 4-8 \mu \mathrm{m}$. Appressoria alternate, unilateral, 1\% opposite, antrorse, to subantrorse, straight, $12-22 \mu \mathrm{m}$ long; stalk cells cylindrical to cuneate, 3-10 $\mu \mathrm{m}$ long; head cells ovate, oblong, globose, entire to slightly angular, 8-13x8-11 $\mu \mathrm{m}$. Phialides mixed with appressoria, opposite to alternate, ampulliform, 12-22x6-8 $\mu \mathrm{m}$. Perithecia scattered, globose, up to $145 \mu \mathrm{m}$ in diameter; perithecial cells mammiform, obtuse at the tip, up to $10 \mu \mathrm{m}$ long; ascospores obovoidal, 4-septate, constricted at the septa, 35-42x12-18 $\mu \mathrm{m}$.

Material examined: HCIO 48165 (holotype), TBGT 2901 (isotype), 27.ix.2006, Kerala, Thiruvananthapuram, Palode Forest area, on leaves of Ixora sp. (Rubiaceae), V.B.Hosagoudar et al.

Based on the digital formula 3101.4220, it can be compared with Asteridiella glabra (Berk. \& Curt.) Hansf. \& Asteridiella uncariicola Hansf. but differs from the former species in having straight and loosely reticulate hyphae and from the latter species in having shorter with only entire head cells of the appressoria (Hansford 1961).

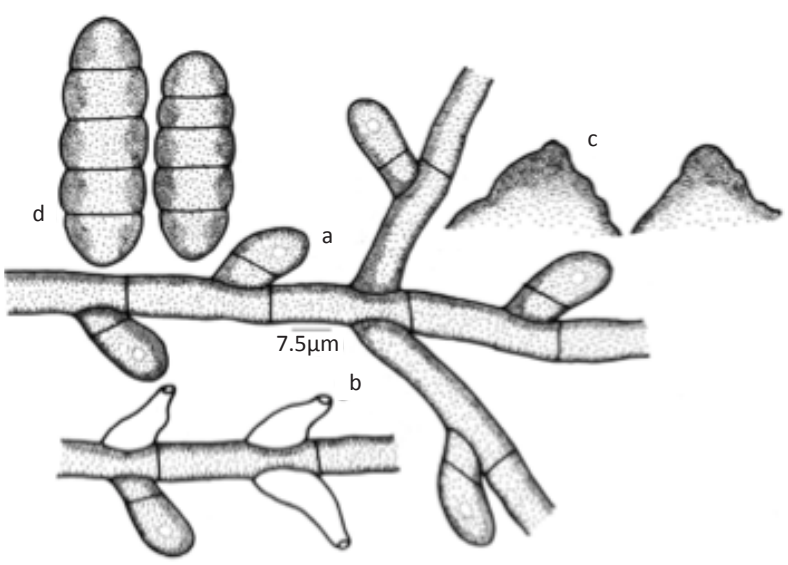

Figure 11. Asteridiella ixorae

a - Appressorium; b - Phialide; c - Perithecial wall cells; $d$ - Ascospores
Asteridiella kodaikanalensis Hosag., Ravikumar \& Archana, J. Threatened Taxa 1(8):434, 2009. (Fig. 12).

Colonies amphigenous, mostly epiphyllous, dense, up to $2 \mathrm{~mm}$ in diameter, confluent and opposite at acute angles, loosely to closely reticulate, cells $11-32 \times 6-10$ $\mu \mathrm{m}$. Appressoria alternate, unilateral, straight, antrorse, 14-27 $\mu \mathrm{m}$ long; stalk cells cylindrical to cuneate, $3.11 \mu \mathrm{m}$ long; head cells mostly straight, globose, ovate, entire, 11-16x9-13 $\mu \mathrm{m}$. Phialides mixed with appressoria, opposite, unilateral, ampulliform, $16-24 \times 6-10 \mu \mathrm{m}$. Perithecia globose, grouped, up to $168 \mu \mathrm{m}$ in diam.; perithecial wall cells conoid to mammiform, up to $32 \mu \mathrm{m}$ long; ascospores cylindrical, 4-septate, constricted at the septa, 35-42x16-18 $\mu \mathrm{m}$.

Material examined: HClO 46807 (holotype), TBGT 2148 (isotype); $\mathrm{HClO}$ 46808, TBGT 2149, 20.ii.2006, Tamil Nadu, Kodaikanal, Shenbaganur Shola, on leaves of Symplocos anamallayana Bedd. (Symplocaceae), K. Ravi Kumar.

This species is similar to Asteridiella fidelis (Toro) Hansf., known on Symplocos theiformis from Philippines in which ascospores are four septate (Hansford 1961). However, A. kodaikanalensis differs from it in having predominantly globose but entire head cells of appressoria and also phialides produced on the mycelial branch where appressoria are also borne.

Asteridiella madikeriensis Hosag., Jagath \& Jayashankara, Mycosphere 2(6): 613, 2011. Asteridiella depokensis sensu Hosag., Meliolales of vol. 2: 127, 2008 (non Hansford 1957). (Fig. 13)

Colonies epiphyllous, dense, up to $2 \mathrm{~mm}$ in diameter. Hyphae flexuous to crooked, branching alternate, opposite to irregular at acute angles, loosely to closely

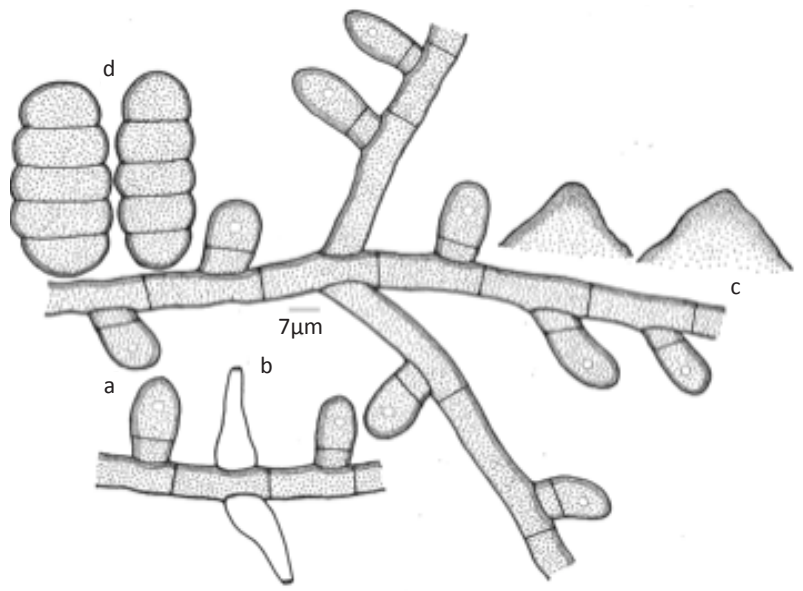

Figure 12. Asteridiella kodaikanalensis

a - Appressorium; b - Phialide; c - Perithecial wall cells; $d$ - Ascospores 
reticulate, cells $19-21 \times 8-10 \mu \mathrm{m}$. Appressoria alternate, antrorse, subantrorse, retrorse, straight to variously curved, 24-37 $\mu \mathrm{m}$ long; stalk cells cylindrical to cuneate, 8-10 $\mu \mathrm{m}$ long; head cells ovate, oblong, globose, angular to variously sublobate, $16-21 \times 12-14 \mu \mathrm{m}$. Phialides mixed with appressoria, alternate to opposite, ampulliform, 19-23x6-8 $\mu \mathrm{m}$. Perithecia scattered, up to $196 \mu \mathrm{m}$ in diam.; perithecial wall cells conoid to mammiform, up to $24 \mu \mathrm{m}$ long; ascospores ellipsoidal, 4-septate, constricted at the septa, 41-45x16-18 $\mu \mathrm{m}$.

Material examined: HCIO 46240 (holotype), TBGT 1652 (isotype), 14.xi.2003, Karnataka, Kodagu, Madikeri, Nishane motta, on leaves of Premna sp. (Verbenaceae), V.B. Hosagoudar et al.

This species differs from Asteridiella depokensis in having sublobate head cells of the appressoria (Hosagoudar 2008).

Asteridiella micheliifolia nom. nov. Asteridiella micheliae Hosag., Archana. \& Agarwal, Indian Phytopath. 60: 237, 2007 (non Jana et al. 2005). (Fig. 14).

(Fig. 14; MycoBank 803916)

Colonies epiphyllous, thin, up to $4 \mathrm{~mm}$ in diameter. Hyphae substraight, branching alternate to opposite at wide angles, loosely reticulate, cells $19-22 \times 3-5 \mu \mathrm{m}$. Appressoria alternate, antrorse, mostly straight, 13-14 $\mu \mathrm{m}$ long; stalk cells cylindrical to cuneate, 5-6 $\mu \mathrm{m}$ long; head cells ovate, oblong, angular to sublobate, 8-10 $x$ 6-8 $\mu \mathrm{m}$. Phialides mixed with appressoria, alternate to opposite, ampulliform, $12-13 \times 4-5 \mu \mathrm{m}$. Perithecia scattered, globose, up to $145 \mu \mathrm{m}$ in diameter; perithecial wall cells mammiform, obtuse at the tip, up to $20 \mu \mathrm{m}$ long; ascospores obovoidal to slightly cylindrical, 4-septate, constricted at the septa, 20-29x10-12 $\mu \mathrm{m}$.

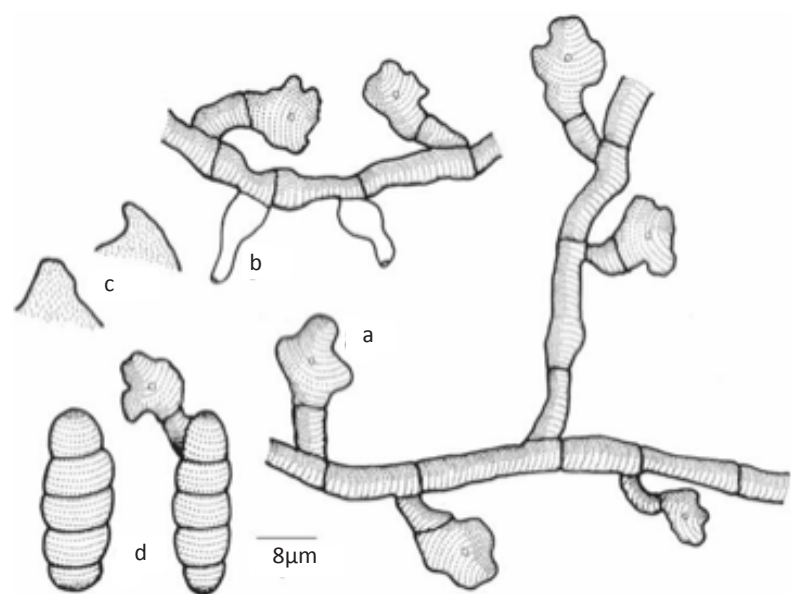

Figure 13. Asteridiella madikeriensis

a - Appressorium; b - Phialide; c - Perithecial wall cells; $d$ - Ascospores
Material examined: HCIO 47370 (holotype), TBGT 2408 (isotype), 12.i.2005, Arboretum, on leaves of Michelia champaka L. (Magnoliaceae), JNTBGRI Campus, Palode, Thiruvananthapuram, Kerala, T. Sabu; HClO 50939, TBGT 4856, 31.iii.2009, A. Sabeena \& M.C. Riju; HCIO 50944, TBGT 4861, 15.xi.2007, A. Sabeena \& M.C. Riju; HCIO 50953, TBGT 4870, 31.iii.2009, A. Sabeena \& M.C. Riju; HCIO 51047, TBGT 4964, 27.xii.2008, Wayanad, $16^{\text {th }}$ mile, Padinharathara, M.C. Riju; HCIO 49973, TBGT 4125, 14.iii.2007, Puthuserrykadavu, M.C. Riju; TBGT 5047, 03.i.2011, Kollam, Chozhiakodu, V.B. Hosagoudar et al.; TBGT 5047, 03.i.2011, Kollam, Chozhiakodu, V.B. Hosagoudar et al.

Asteridiella micheliae Hosag. et al. \& Asteridiella micheliae Jana et al. are known on the same host genus from Kerala and Nagaland, respectively (Hosagoudar et al. 2007; Jana et al. 2005). However, the former species differs from the latter in having shorter appressoria with angular to sublobate head cells, phialides and appressoria borne on the same hyphae and possessing smaller ascospores. Taxonomically, both are different species. Hence, a new name has been proposed to Asteridiella micheliae Hosag. et al.

Asteridiella phukanea Hosag., Jacob. \& Robin, Indian J. Sci. Technol. 2(6): 3, 2009. (Fig. 15)

Colonies amphigenous, mostly epiphyllous, up to $2 \mathrm{~mm}$ in diameter, confluent. Hyphae substraight to slightly undulate, branching alternate to opposite at acute to wide angles, closely reticulate, cells 21-28x7$10 \mu \mathrm{m}$. Appressoria alternate, antrorse to sub antrorse, 24-31 $\mu \mathrm{m}$ long; stalk cells cylindrical to cuneate, 5-12 $\mu \mathrm{m}$ long; head cells ovate, globose, entire, angular to slightly lobate, 14-22x10-19 $\mu \mathrm{m}$. Phialides mixed with appressoria, opposite to alternate, ampulliform,

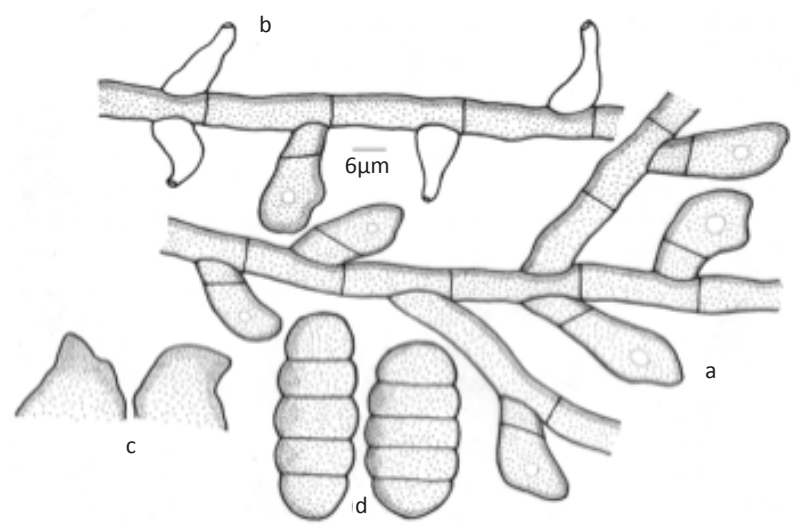

Figure 14. Asteridiella micheliifolia nom. nov.

a - Appressorium; b - Phialide; c - Perithecial wall cells; d - Ascospores 
17-22x7-10 $\mu \mathrm{m}$. Perithecia scattered, up to $120 \mu \mathrm{m}$ in diameter; ascospores obovoidal to cylindrical, 3-septate, constricted at the septum, 36-43×16-18 $\mu \mathrm{m}$.

Material examined: HClO 48066 (holotype), TBGT 2849 (isotype), 18.i.2007, Meghalaya, Shillong, Mawphlang, on leaves of Castanopsis armata Spach. (Fagaceae), Jacob Thomas \& P.J. Robin.

This new species is distinct from all the known species of the genus Asteridiella known on the members of the family Fagaceae in having three septate ascospores (Hansford 1961; Hosagoudar 1996; Hu et al. 1996, 1999).

Asterediella pittosporacearum Hosag. \& Sabeena, Plant Pathology \& Quarantine 3(1): 10, 2012. (Fig. 16).

Colonies amphigenous, thin to subdense, up to $2 \mathrm{~mm}$ in diameter, confluent. Hyphae straight to substraight, branching opposite to irregular at acute to wide angles, loosely to closely reticulate, cells $17-30 \times 5-7 \mu \mathrm{m}$. Appressoria alternate, antrorse to subantrorse, 12-17 $\mu \mathrm{m}$ long; stalk cells cylindrical to cuneate, $2-5 \mu \mathrm{m}$ long; head cells globose to ovate, entire, 10-12x5-12 $\mu \mathrm{m}$. Phialides mixed with appressoria, opposite, ampulliform, 15-25x5-10 $\mu \mathrm{m}$. Perithecia scattered, up to $110 \mu \mathrm{m}$ in diam.; Perithecial cells conoid to mammiform, up to $22 \mu \mathrm{m}$ long; ascospores cylindrical, 4-septate, constricted at the septa, 37-42x15-17 $\mu \mathrm{m}$.

Materials examined:TBGT5731 (holotype), 20.i.2009, Kerala, Kottayam, Pampavalley, on leaves of Pittosporum neelgherrense Wight \& Arn. (Pittosporaceae), Jacob Thomas et al. Part of the collection has been deposited in $\mathrm{HClO}$, New Delhi.

Five species of the genus Meliola are known on the

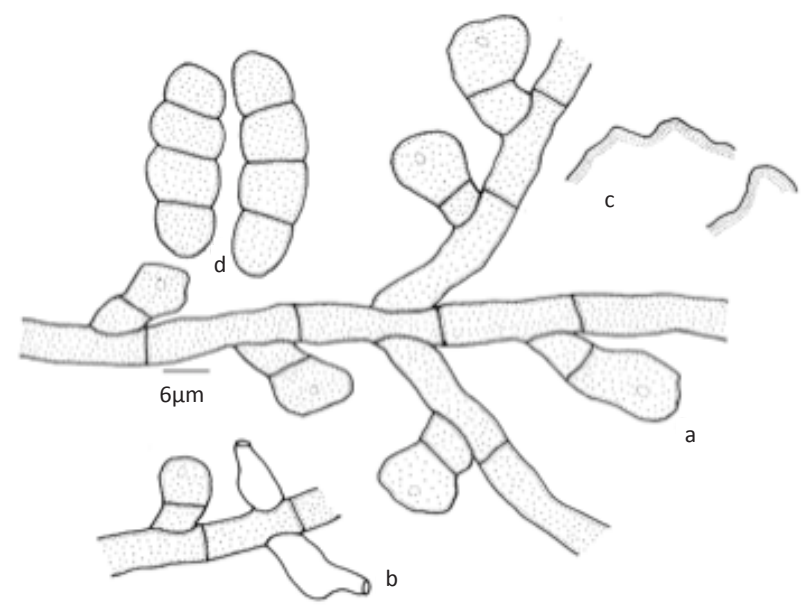

Figure 15. Asteridiella phukanea

a - Appressorium; b - Phialide; c - Perithecial wall cells; $d$ - Ascospores

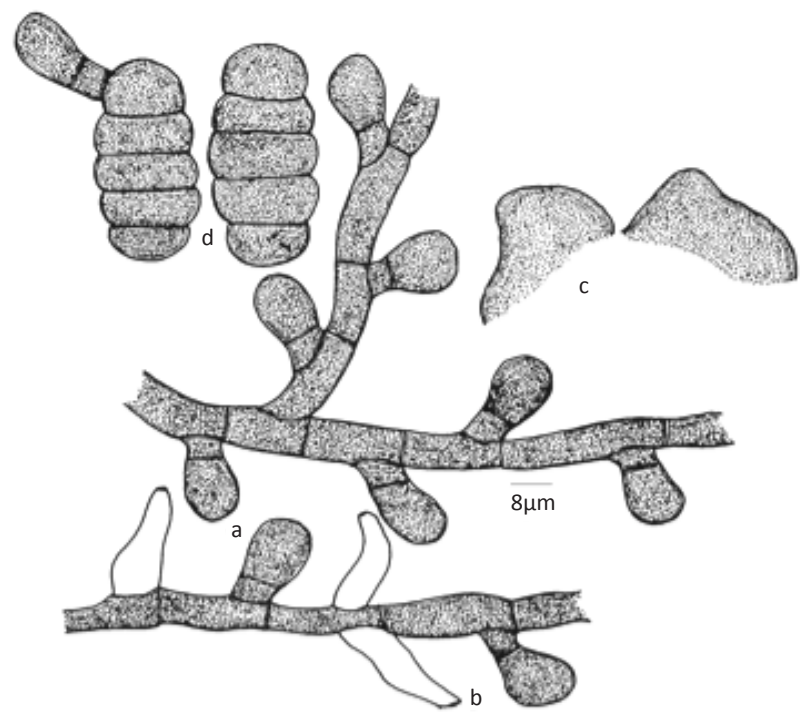

Figure 16. Asterediella pittosporacearum

a - Appressorium; b - Phialide; c - Perithecial wall cells; $d$ - Ascospores

members of Pittosporaceae (Hansford 1961). However, the present collection differs from all in absence of mycelial setae and form the first species of the genus Asteridiella on the members of Pittosporaceae.

Asteridiella scolopiae var. indica Hosag. \& Riju, Plant Pathology \& Quarantine 1(2): 121, 2011. (Fig. 17).

Colonies epiphyllous, scattered, crustose, mostly near the leaf margins, up to $4 \mathrm{~mm}$ in diam., often confluent. Hyphae substraight to crooked, branching alternate to opposite at acute to wide angles, loosely to closely reticulate, cells $12-25 \times 7-10 \mu \mathrm{m}$. Appressoria alternate, unilateral, up to $1 \%$ opposite, antrorse, subantrorse to retrorse, 15-25 $\mu \mathrm{m}$ long; stalk cells cylindrical to cuneate, 2-10 $\mu \mathrm{m}$ long; head cells ovate, oblong to cylindrical, straight to curved, entire to angular, $10-15 \times 7-10 \mu \mathrm{m}$. Phialides mixed with appressoria, ampulliform, 17$23 \times 7-8 \mu \mathrm{m}$. Perithecia scattered, up to $145 \mu \mathrm{m}$ in diam.; perithecial wall cells conoid to mammiform, straight to curved, 12-15×22-28 $\mathrm{mm}$; ascospores oblong, 4-septate, slightly constricted at the septa, 35-43×15-18 $\mu \mathrm{m}$.

Material examined: TBGT 5066 (holotype), 10.i.2007, Kerala, Pathanamthitta, Sabarigiri project area, on leaves of Scolopia sp. (Flacourtiaceae), M.C. Riju et al. Part of the collection has been deposited in $\mathrm{HClO}$, New Delhi.

The variety differs from the species type in having straight to curved and antrorse to retrorse appressoria (Hosagoudar 1996).

Asteridiella sebastianiae Hosag., Sabeena \& Jacob Thomas, Taprobanica 2(2): 95, 2010. (Fig. 18). 


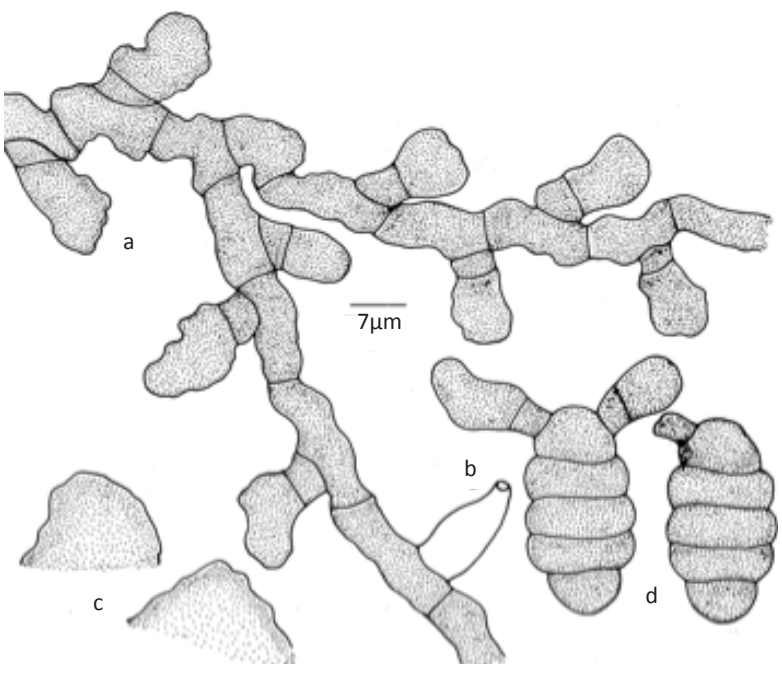

Figure 17. Asteridiella scolopiae var. indica

a - Appressorium; b - Phialide; c - Perithecial wall cells; $d$ - Ascospores

Colonies amphigenous, thin, up to $2 \mathrm{~mm}$ in diameter, confluent. Hyphae substraight, flexuous to crooked, branching opposite to unilateral at acute to wide angles, cells 20-50x6-9 $\mu \mathrm{m}$. Appressoria alternate to unilateral, antrorse, subantrorse to retrorse, straight to curved, 18-29 $\mu \mathrm{m}$ long; stalk cells cylindrical to cuneate, 4-9 $\mu \mathrm{m}$ long; head cells ovate, globose, entire, angular, 13-20x9-13 $\mu \mathrm{m}$. Phialides mixed with appressoria, alternate to opposite, ampulliform, 15-24x6-9 $\mu \mathrm{m}$. Perithecia globose, scattered, up to $172 \mu \mathrm{m}$ in diameter; perithecial walls conoid, up to $26 \mu \mathrm{m}$ long; ascospores oblong, ellipsoidal to cylindrical, 4-septate, constricted at the septa, 31-37x9-13 $\mu \mathrm{m}$.

Material examined: $\mathrm{HClO} 48046$ (holotype), TBGT 2829 (isotype), 14.v.2007, Kerala, Thiruvananthapuram, Palode, JNTBGRI Campus, on leaves of Sebastiania chamaelea (L.) Mull. (Euphorbiaceae), A. Sabeena et al.; HCIO 48365, TBGT 3086, 10.vi.2007, A. Sabeena \& Bijeesh; HClO 48367, TBGT 3088, 14.v.2007, A. Sabeena \& Bijeesh; HCIO 50587, TBGT 4504, 21.iv.2010, A. Sabeena; Thiruvananthapuram, Peppara Wildlife Sanctuary, Kottoor Forest, HClO 48836, TBGT 3212, 10.ii.2008, Jacob Thomas \& Anilkumar.

Asteridiella sebastianiae can be compared with Asteridiella phyllanthi (Deight.) Hansf., A. erythrococcae Hansf., A. hansfordii (Stev.) Hansf. var. densa (Hansf. \& Deight.) Hansf., A. macarangicola Hosag. \& A. wayanadensis Hosag. et al. (Hansford 1961; Biju et al. 2005; Hosagoudar 1996, 2008; Hosagoudar \& Agarwal, 2008) having the beeli formula 3101. 3220. However, it differs from $A$. phyllanthi, $A$. hansfordii var. densa, $A$. macarangicola and $A$. combeensis in having distinctly

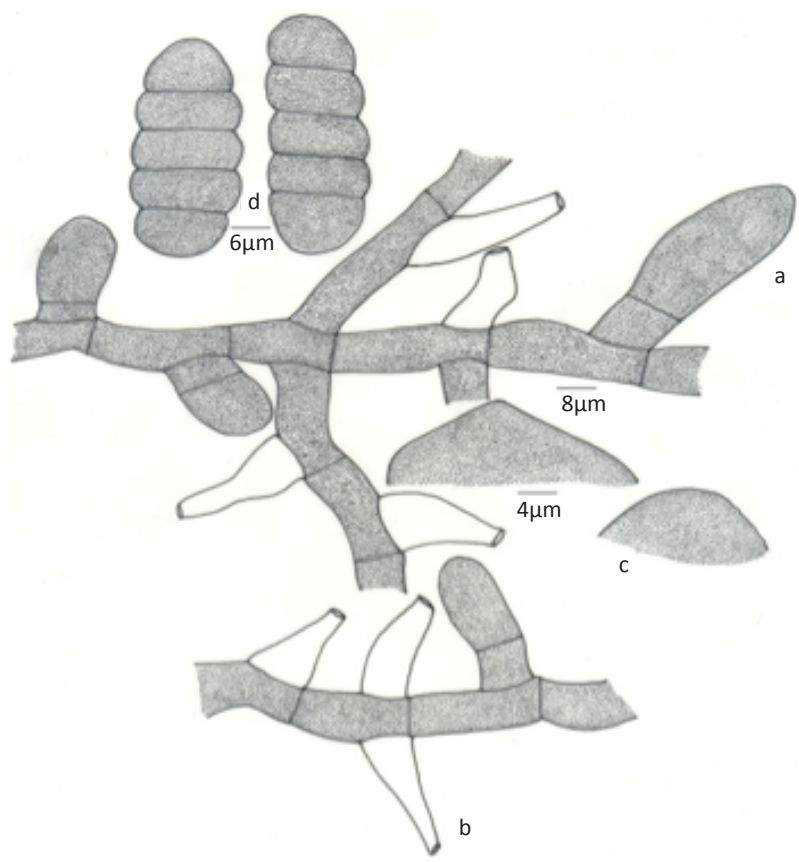

Figure 18. Asteridiella sebastianiae

a - Appressorium; b - Phialide; c - Perithecial wall cells; d - Ascospores

narrow ascospores (9-13 $\mu \mathrm{m}$ against 16-18 $\mu \mathrm{m})$. It differs from $A$. erythrococcae in having entire head cells of the appressoria in contrast to angulose to sublobate. Asteridiella sebastianiae also differs from A. wayanadensis in having longer, antrorse to retrorse appressoria. This is first report of meliolaceous fungi on this host genus.

Asteridiella shenbaganurensis Hosag., Ravikumar \& Archana, J. Threatened Taxa 1(8): 434, 2009. (Fig. 19).

Colonies amphigenous, mostly epiphyllous, dense, up to $2 \mathrm{~mm}$ in diameter, confluent and cover an entire upper surface of the leaves. Hyphae straight to substraight, branching opposite to alternate at acute to wide angles, loosely to closely reticulate, cells 1642×8-10 $\mu \mathrm{m}$. Appressoria alternate, unilateral, straight to often slightly curved, antrorse to subantrorse, 17-42 $\mu \mathrm{m}$ long; stalk cells mostly unicellular, rarely 1-septate, cylindrical to cuneate, 4-18 $\mu \mathrm{m}$ long; head cells mostly straight, often curved, oblong, ovate, clavate, mostly entire, often angular, rarely sublobate, 9-24x8-16 $\mu \mathrm{m}$. Phialides mixed with appressoria, opposite, alternate, unilateral, ampulliform, 20-37x8-10 $\mu \mathrm{m}$. Perithecia globose, grouped, up to $208 \mu \mathrm{m}$ in diam.; perithecial wall cells conoid to mammiform, up to $32 \mu \mathrm{m}$ long; ascospores ellipsoidal to fusiform, straight to curved, 3-septate, constricted at the septa, 43-49x14-19 $\mu \mathrm{m}$.

Material examined: HClO 46808 (holotype), TBGT 


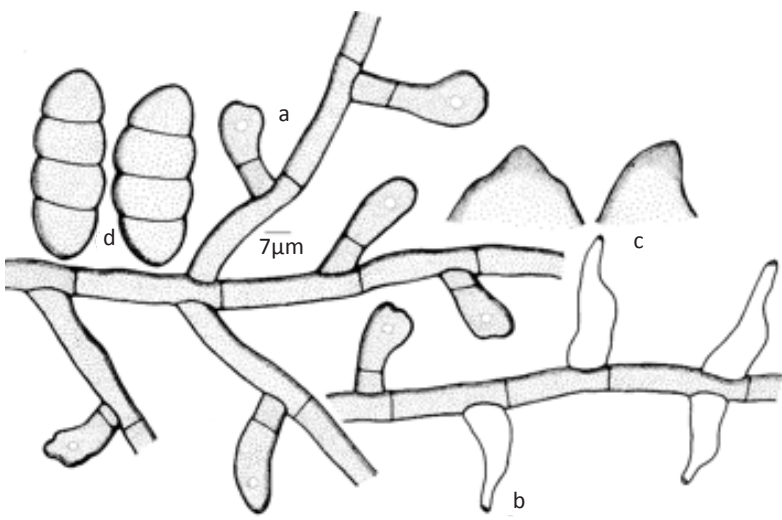

Figure 19. Asteridiella shenbaganurensis

a - Appressorium; b - Phialide; c - Perithecial wall cells; $d$ - Ascospores

2149 (isotype). (MycoBank \# MB5140117), 20.ii.2006, Tamil Nadu, Kodaikanal, Shenbaganur Shola, on leaves of Symplocos anamallayana Bedd. (Symplocaceae), K. Ravi Kumar.

This species is similar to Asteridiella singalensis Hansf., reported on Symplocos sp. from Sri Lanka, in having 3-septate ascospores (Hansford 1961). However, differs from it in having distinctly oblong and entire to angular head cells of appressoria. Further, phialides are mixed with appressoria and having smaller ascospores.

Asteridiella solani Mc Alpine var. kodaikanalensis Hosag., Dhivaharan \& Riju, J. Sci. Trans. Techno. 4(4): 165, 2011. (Fig. 20).

Colonies mostly epiphyllous, scattered, subdense, velvety, up to $2 \mathrm{~mm}$ in diameter. Hyphae flexuous, branching alternate at acute to wide angle, closely to loosely reticulate, cells 22-27x5-7 $\mu \mathrm{m}$. Appressoria alternate, straight to curved, subantrorse to closely antrorse, 15-17 $\mu \mathrm{m}$ long; stalk cells cylindrical to cuneate, 5-7 $\mu \mathrm{m}$; head cells globose, sub-lobate, slightly angular, entire, 10-12x7-10 $\mu \mathrm{m}$. Phialides borne on a separate mycelial branch, alternate, rarely opposite, ampulliform, 15-17x7-10 $\mu \mathrm{m}$. Perithecia scattered to grouped, up to $225 \mu \mathrm{m}$ in diameter; perithecial cells larviform, mammiform, 12-15x12-17 $\mu \mathrm{m}$; ascospores 4septate, cylindrical, 35-43×12-15 $\mu \mathrm{m}$.

Materials examined: 4457 (holotype), $\mathrm{HClO}$ 50540 (isotype), 02.ii.2008, Tamil Nadu, Kodaikanal, Periyakanal, Kukkal shola forest, on leaves of Solanum viburnum (Solanaceae), V. Dhivaharan et al.

Based on the digital formula, morphology of the hyphae and appressoria, the present collection is similar to Asterina solani known on Solanum viride from New South Wales but the new variety differs from it in having the phialides borne on a separate mycelial branch.

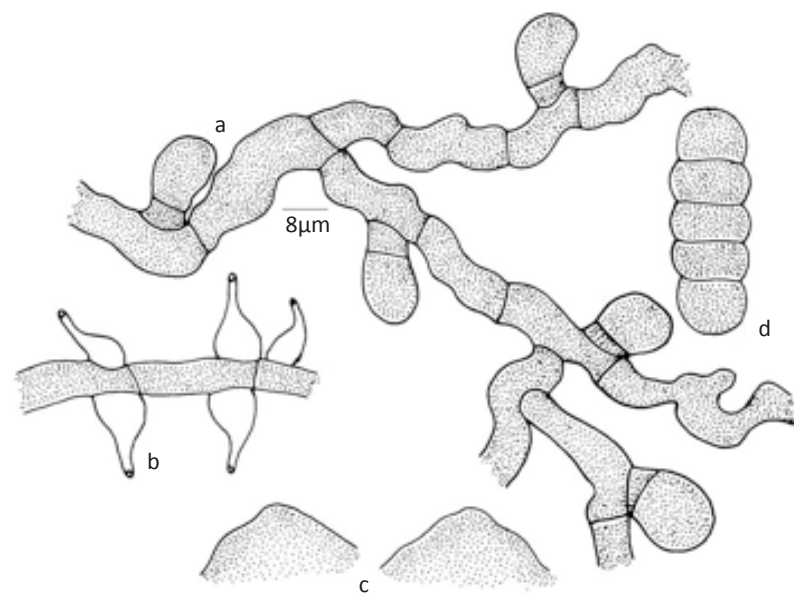

Figure 20. Asteridiella solani var. kodaikanalensis

a - Appressorium; b - Phialide; $d$ - Ascospores; e - Perithecial wall cells

Asteridiella symploci-microphyllae Hosag. \& Sabeena, Bioscience Discovery 2: 117, 2011. (Fig. 21).

Colonies amphigenous, subdense, up to $3 \mathrm{~mm}$ in diameter, confluent. Hyphae straight to substraight, branching opposite to unilateral at acute to wide angles, loosely to closely reticulate, cells $17-32 \times 6-8$ $\mu \mathrm{m}$. Appressoria alternate to unilateral, antrorse to subantrorse, 15-20 $\mu \mathrm{m}$ long; stalk cells cylindrical to cuneate, 2-7 $\mu \mathrm{m}$ long; head cells globose to ovate, entire, 10-15x10-12 $\mu \mathrm{m}$. Phialides mixed with appressoria, alternate to opposite, ampulliform, 15-25x5-10 $\mu \mathrm{m}$. Perithecia scattered, up to $240 \mu \mathrm{m}$ in diam., perithecial wall cells conoid to mammiform, up to $50 \mu \mathrm{m}$ long; ascospores cylindrical, 4-septate, constricted at the septa, 32-40x15-17 $\mu \mathrm{m}$.

Material examined: TBGT 4553 (holotype), HCIO 50536 (isotype), 01.xi.2007, Kerala, Wayanad, Banasuramala, on leaves of Symplocos macrophylla Wallich. ex DC. (Symplocaceae), A. Chandraprabha.

Asterediella singalensis Hansf. \& A. fidelis (Toro) Hansf. are known on the genus Symplocos sp. from Srilanka, Columbia and Philippines (Hansford 1961). However, the present new species differs from the former in having 4-septate ascospores and from the latter in having entire head cells of appressoria in contrast to angular ones.

Asteridiella toddaliae Hosag. \& Riju, J. Threatened Taxa 3(3): 1615, 2011. (Fig. 22).

Colonies amphigenous, dense, velvety, up to $3 \mathrm{~mm}$ diam., rarely confluent. Hyphae straight, substraight to undulating, branching mostly opposite at wide angles, loosely to closely reticulate, cells $22-30 \times 7-10 \mu \mathrm{m}$. Appressoria alternate, unilateral, about $10 \%$ opposite, antrorse to subantrorse, rarely retrorse, $12-25 \mu \mathrm{m}$ long; 


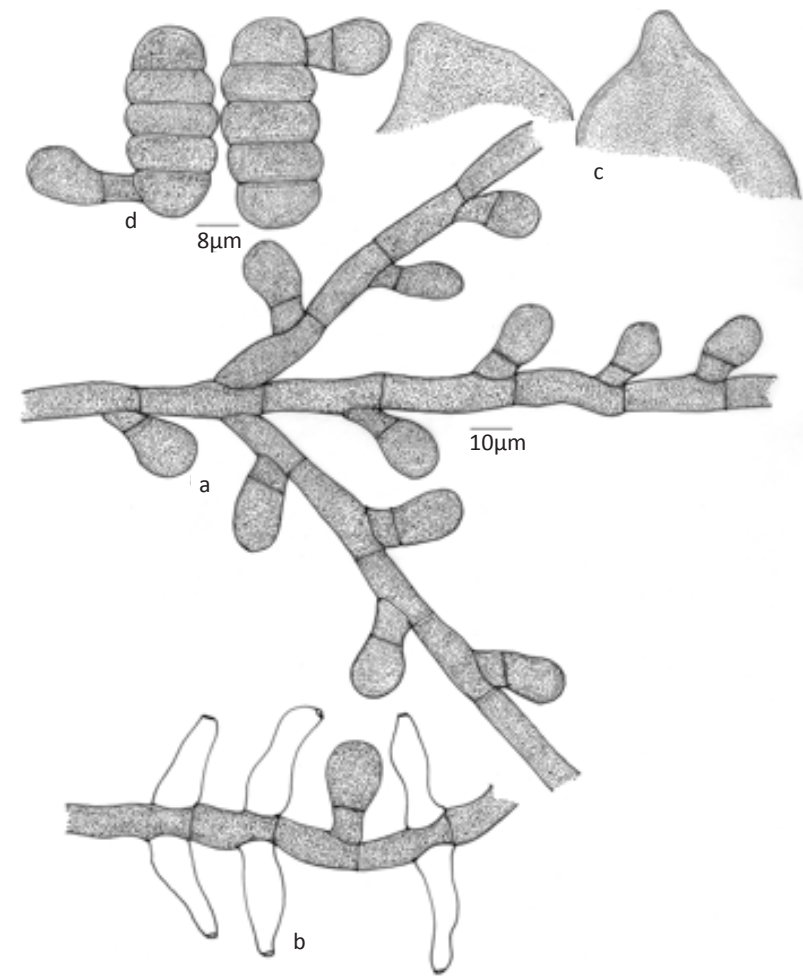

Figure 21. Asteridiella symploci-microphyllae

a - Appressorium; b - Phialide; $d$ - Ascospores; e - Perithecial wall cells

stalk cells cylindrical to cuneate, $2-8 \mu \mathrm{m}$ long; head cells ovate, globose, entire, 10-18 x 7-13 $\mu \mathrm{m}$. Phialides mixed with appressoria, alternate, opposite, ampulliform, 15$23 \times 5-8 \mu \mathrm{m}$. Perithecia loosely grouped at the centre of the colony, up to $210 \mu \mathrm{m}$ in diam.; perithecial wall cells mammiform to conoid, 17-28 $\mu \mathrm{m}$ long; ascospores oblong to ellipsoidal, 4-septate, constricted at the septa, 45-48x22-25 $\mu \mathrm{m}$.

Material examined: TBGT 4513 (holotype), HCIO 50596(isotype),(MycoBank\#561021),02.vii.2008, Kerala, Palakkad, Silent Valley National Park, Cheriavalakkad, on leaves of Toddalia asiatica (L.) Lam. (Rutaceae), M.C. Riju et al.; Palakkad, on leaves of Toddalia sp., $\mathrm{HClO} 50719$, TBGT 4636, 16.iii.2007, Robin et al.

Of the known species of the genus Asteridiella on Rutaceae, Asteridiella obesa (Speg.) Hansf. var. obesula (Speg.) Hansf. \& A. fagaricola (Speg.) Hansf. var. zanthoxyli Hansf. having alternate and opposite appressoria (Hansford 1961). The present new species differs from the former taxon known on Esenbeckia latifolia from Paraguay in having perfectly rounded head cells of appressoria in contrast to rounded-angulose. It also differs from the latter taxon known on Zanthoxylum hymenale from Argentina in having only $10 \%$ opposite appressoria in contrast to 90\% (Hansford 1961). The specific epithet is derived from the host genus.

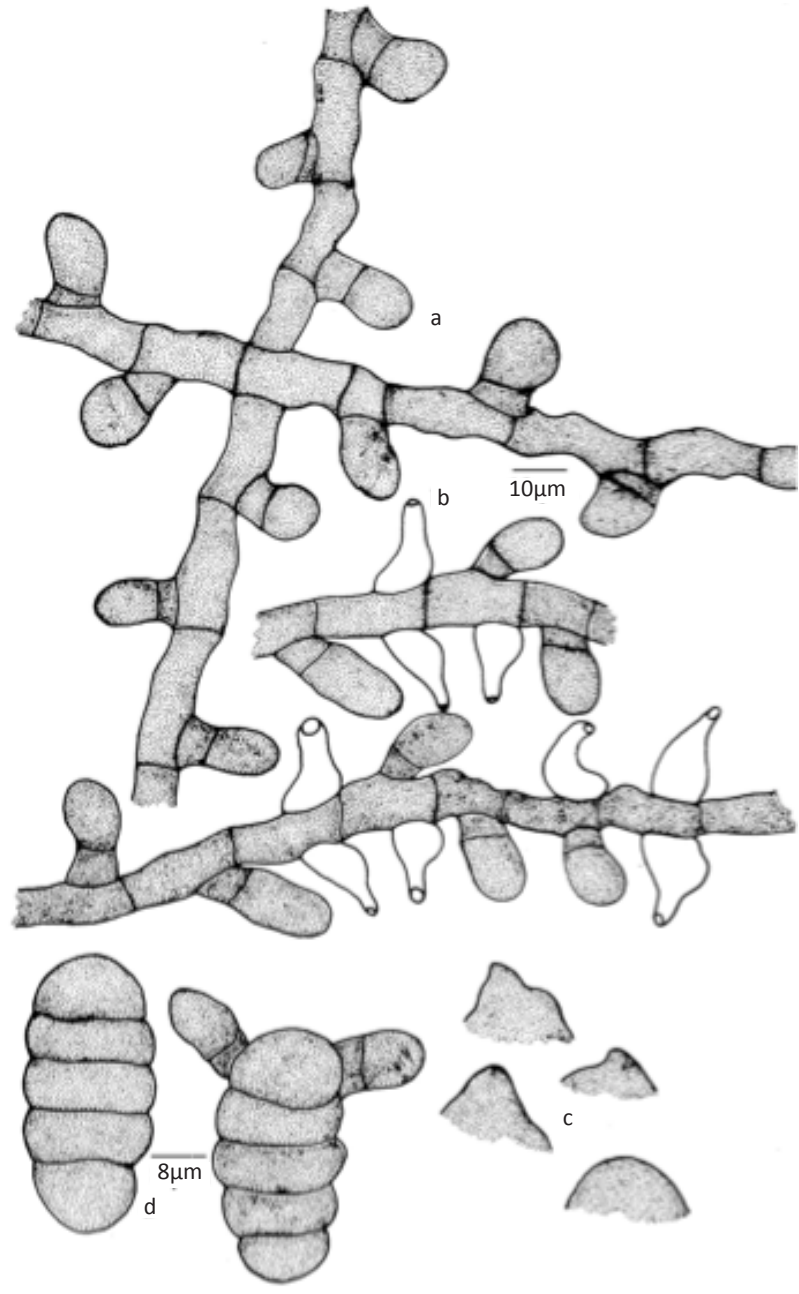

Figure 22. Asteridiella toddaliae

a - Appressorium; b - Phialide; $d$ - Ascospores; e - Perithecial wall cells

Asteridiella viticis-negundoi Hosag., Jagath \& Jayashankara, Mycosphere 2(6): 614, 2011. (Image. 6)

Colonies epiphyllous, dense, up to $3 \mathrm{~mm}$ in diameter. Hyphae straight, substraight to flexuous, branching alternate to opposite at acute to wide angles, loosely reticulate, cells $18-23 \times 7-10 \mu \mathrm{m}$. Appressoria alternate, antrorse to subantrorse, straight to curved, 20-32 $\mu \mathrm{m}$ long; stalk cells cuneate to cylindrical, 6-12 $\mu \mathrm{m}$ long; head cells globose, ovate, clavate to cylindrical, mostly angular, few sublobate, rarely entire, truncate, 15-23x11-20 $\mu \mathrm{m}$. Phialides many, apparently borne on a separate mycelial branch but mixed with appressoria, mostly opposite, often unilateral, ampulliform, 16-22x5-7 $\mu \mathrm{m}$. Perithecia scattered, globose, up to $150 \mu \mathrm{m}$ in diam.; perithecial wall cells mammiform to conoid, attenuated at tip, up to $22 \mu \mathrm{m}$ long; ascospores oblong to cylindrical, 4-septate, constricted at the septa, 48-50x18-21 $\mu \mathrm{m}$.

Material examined: TBGT 5704 (holotype), 
29.xii.2008, Karnataka, Kodagu, Hoddur, on leaves of Vitex negundo L. (Verbenaceae), C. Jagath Thimmaiah.

Based on the morphology of appressoria and measurements, this collection can be compared with Asteridiella lagerheimii (Gaill.) Hansf. \& A. depokensis Hansf. known on Citherexylum ilicifolium and Vitex paniculata and Premna subglabra from Eucador, Java and Philippines. However, differs from the former species in having distantly placed and recurved appressoria with typically angular head cells. It differs from the latter species in having flexuous hyphae and larger ascospores (Hansford 1961).

Asteridiella winteri (Speg.) Hansf. var. macrospora Jana \& Ghosh, J. Mycopath. Res. 47(1): 91, 2009.

Colonies epiphyllous, thin, up to $6 \mathrm{~mm}$ in diameter, confluent. Hyphae flexuous, branching alternate, opposite to unilateral at acute angles, closely reticulate, cells 19-50x6-11 $\mu \mathrm{m}$. Appressoria alternate, alternate to rarely opposite, antrorse, straight to curved, 17-36 $\mu \mathrm{m}$ long; stalk cells cylindrical, 5-16 $\mu \mathrm{m}$ long; head cells ovate to cylindrical, sometimes reniform entire, 1220x10-15 $\mu \mathrm{m}$. Phialides borne on a separate mycelial branch, alternate to unilateral, ampulliform, 18-27x7$11 \mu \mathrm{m}$. Perithecia scattered to loosely grouped, up to $200 \mu \mathrm{m}$ in diameter; perithecial wall cells projected; asci oval to elliptical, 2-spored, 55-64×39-51 $\mu \mathrm{m}$; ascospores cylindrical, straight, 4-septate, constricted at the septa, middle cell slightly larger, 60-80×32-38 $\mu \mathrm{m}$.

West Bengal, Chilapata forest, Cooch Behar, on leaves
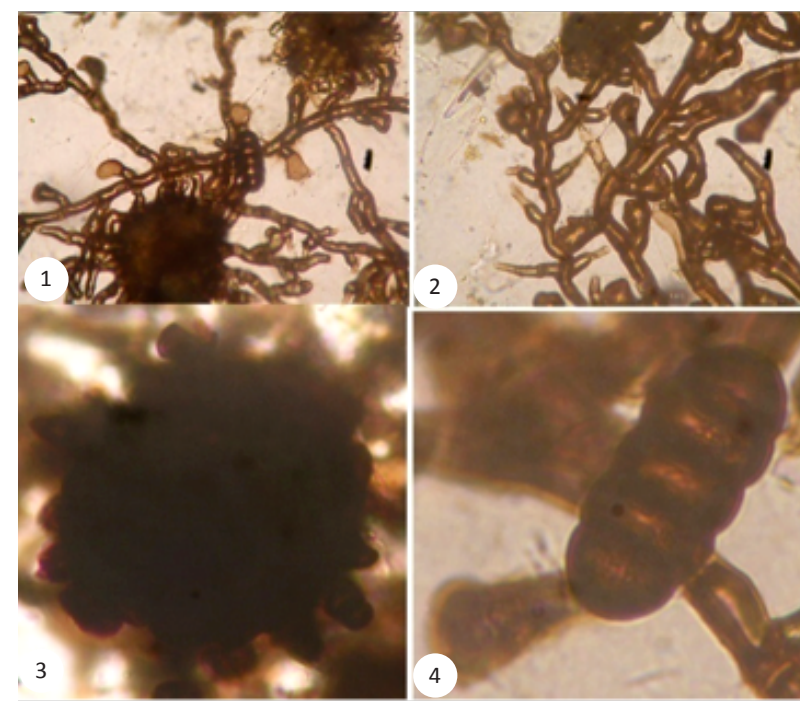

Image 6. Asteridiella viticis-negundoi

1- Fungal colony formed from the ascospores; 2 - Appressoria mixed with phialides; 3 - Perithecium with projected wall cells;

4 - Germinated ascospore; Bars $=12 \mu \mathrm{m}$ of Solanum verbasifolium L. (Solanaceae), 20August 1984, S.N. Ghosh IMI 233927 (holotype).

\section{THE GENUS ECTENDOMELIOLA}

Ectendomeliola otonephelii Hosag. \& Archana, J. Threatened Taxa 2(8): 1092, 2010. (Image. 7; Fig. 23).

Colonies hypophyllous, subdense, crustose, up to $4 \mathrm{~mm}$ in diameter, often confluent. Hyphae substraight to crooked, branching irregular at acute angles, form irregular mycelial net, loosely to closely reticulate, cells beaded to bulged, 11-29x4-7 $\mu \mathrm{m}$. Appressoria ectophytic and endophytic, innate appressoria intraepidermal, often in mesophyll cells, two celled, 11-24 $\mu \mathrm{m}$ long; stalk cells cylindrical to cuneate, $3-8 \mu \mathrm{m}$ long; head cells ovate, globose, oblong, entire to angular, 8-16x6-8 $\mu \mathrm{m}$. Phialides few, mixed with appressoria, opposite, ampulliform, 9-22x6-8 $\mu \mathrm{m}$. Mycelial setae numerous, simple, straight to uncinate, acute, obtuse, dentate to furcate at the tip, up to $412 \mu \mathrm{m}$ long. Perithecia superficial, scattered to grouped, globose, ostiolate, up to $126 \mu \mathrm{m}$ in diameter; ascospores oblong, cylindrical, straight to slightly curved, 4-septate, constricted at the septa, 35-4x11-15 $\mu \mathrm{m}$.

Materials examined: TBGT 3941 (holotype), HCIO 49789 (isotype) (MycoBank \# 518657), 14.xii.2007, Kerala, Patanamthitta, Moozhiyar forest, on leaves of

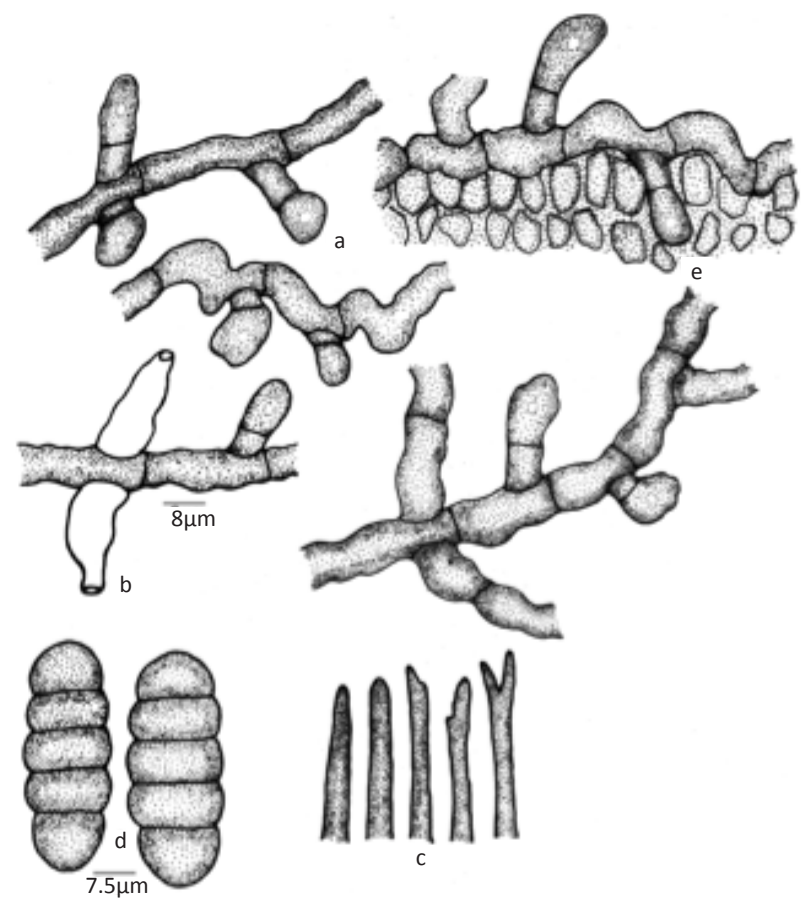

Figure 23. Ectendomeliola otonephelii

a - Appressorium; b - Phialide; c - Apical portion of the mycelial setae; d - Ascospores; e - Innate appressorium 


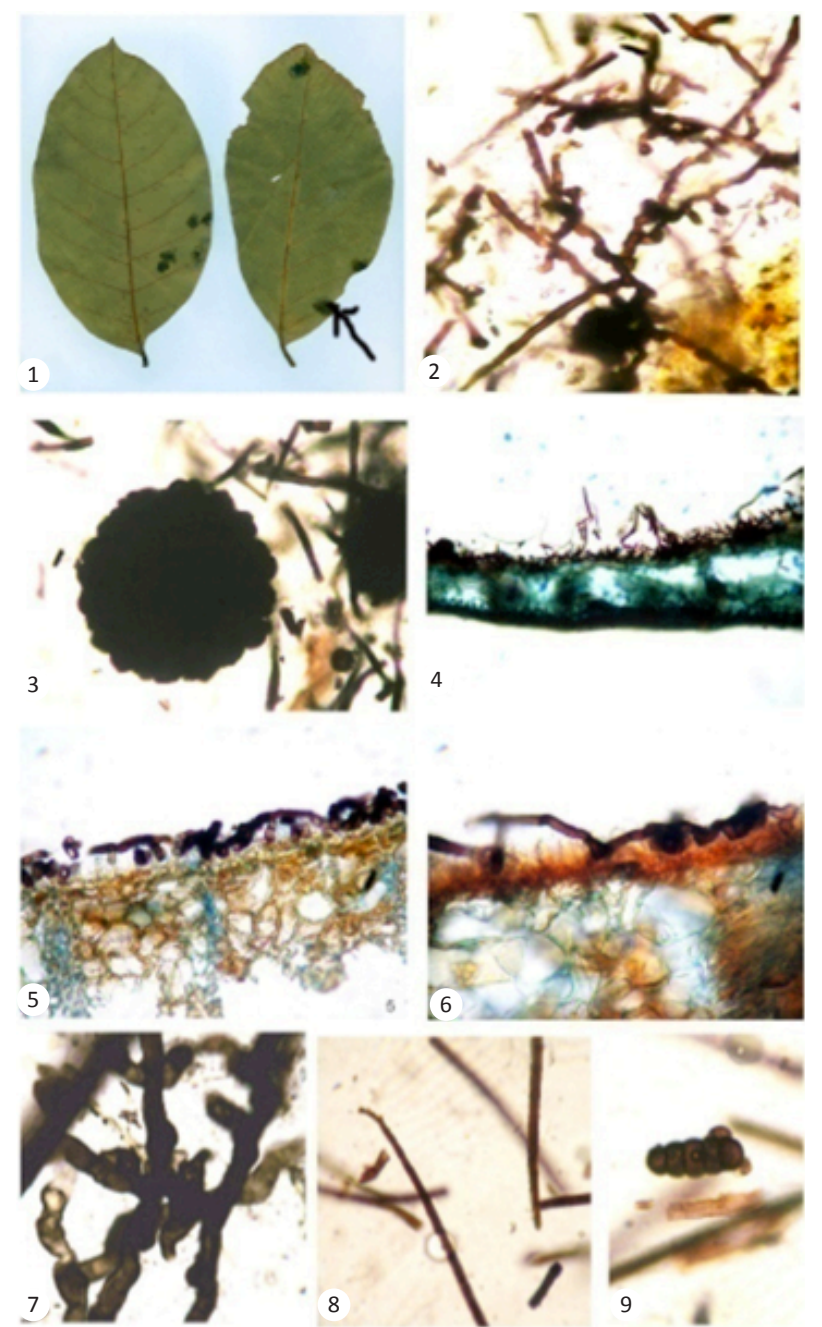

Image 7. Ectendomeliola otonephelii

1 - Hypophyllous colonies on the leaves; 2 - Crooked mycelium with appressoria with an intermitant mycelial knot; 3 - Perithecium;

4 - T.S. showing the arrangement of mycelium and appressoria;

5 - Subepidermal appressoria; 6 - Mycelium, appressorium and initials of perithecia; 7 - Phialides on the mycelium; 8 - Apical tip of mycelial setae; 9 - Ascospore

Otonephelium stipulaceum (Bedd.) Radlk. (Sapindaceae), V. Gireesh Kumar et al. This species differs from $E$. walsurae in having longer mycelial setae and larger perithecia.

\section{THE GENUS IRENOPSIS}

Irenopsis hiptages Yamam. var. indica Hosag. \& Sabeena, var. nov.

(Fig. 24; MycoBank 803918)

Colonies amphigenous, subdense, up to $3 \mathrm{~mm}$ in diameter, confluent. Hyphae straight to substraight, branching opposite at acute to wide angles, loosely reticulate, cells $17-25 \times 6-8 \mu \mathrm{m}$. Appressoria alternate, unilateral to $3-4 \%$ opposite, antrorse to subantrorse, 22-30 $\mu \mathrm{m}$ long; stalk cells cylindrical to cuneate, 5-10 $\mu \mathrm{m}$ long; head cells ovate, entire, mostly angular to rarely sublobate, $15-20 \times 12-17 \mu \mathrm{m}$. Phialides mixed with appressoria, alternate to opposite, ampulliform, 1525x7-10 $\mu \mathrm{m}$. Perithecia scattered orbicular, up to $190 \mu \mathrm{m}$ in diam.; perithecial setae simple, straight, obtuse at the tip, up to $117 \mu \mathrm{m}$ long; ascospores cylindrical, 4-septate, constricted at the septa, 47-55x17-22 $\mu \mathrm{m}$.

Materials examined: TBGT 5747 (holotype), 18.ix.2008, Kerala, Wayanad, Thirunelli, on leaves of Hiptage sp. (Malphigiaceae), P.J. Robin et al.

This collection matches with the species but the new variety differs from it in having $2-3 \%$ opposite appressoria with mostly angular but often with slightly lobate head cells of appressoria.

Etymology: It is named after India.

Irenopsis kleinhoviae Hosag. \& Archana, J. Threatened Taxa 2: 889, 2010. (Fig. 25)

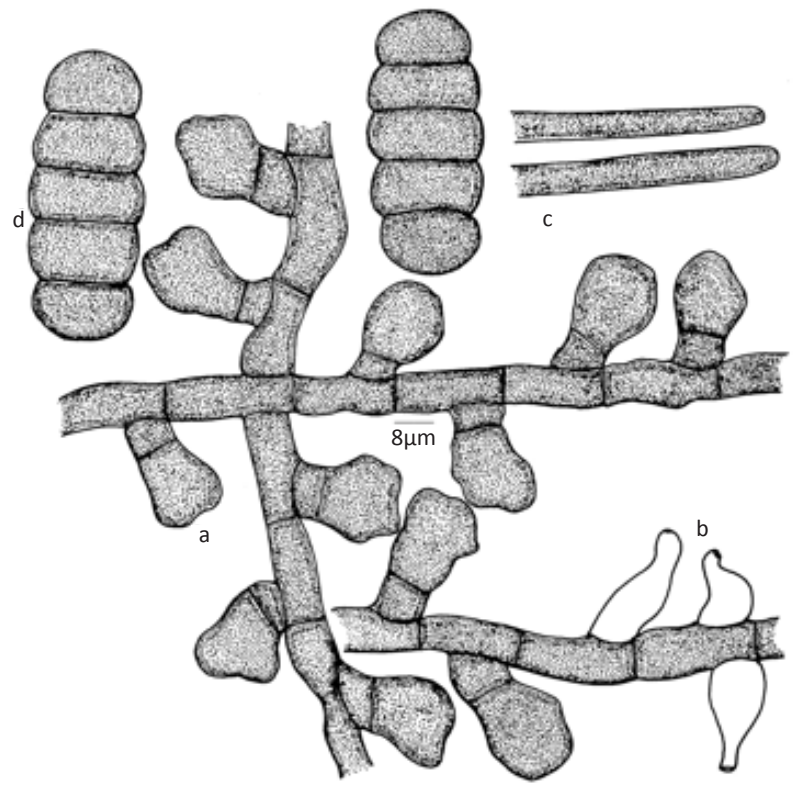

Figure 24. Irenopsis hiptages var. indica var. nov.

a - Appressorium; b - Phialide; c - Apical portion of the mycelial setae; d - Ascospores 
Colonies amphigenous, subdense, up to $5 \mathrm{~mm}$ in diameter, confluent. Hyphae substraight to undulate, branching opposite, alternate at acute to wide angles, loosely to closely reticulate, cells 16-40x4-7 $\mu \mathrm{m}$. Appressoria alternate, unilateral, antrorse, subantrorse to retrorse, straight to curved, 12-23 $\mu \mathrm{m}$ long; stalk cells cylindrical to cuneate, 3-11 $\mu \mathrm{m}$ long; head cells globose, ovate, oblong, entire to angular, 8-14x8$11 \mu \mathrm{m}$. Phialides mixed with appressoria, opposite to alternate, ampulliform, 12-24x4-8 $\mu \mathrm{m}$. Perithecia globose, scattered to grouped, up to $130 \mu \mathrm{m}$ in diameter; perithecial setae 4-10 in number, simple, straight, pale brown, septate, straight to uncinate at the apical part, obtuse at the tip, up to $145 \mu \mathrm{m}$ long, smooth; ascospores obovoidal, 4-septate, slightly constricted at the septa, 32-43x11-18 $\mu \mathrm{m}$.

Material examined: HClO 48166 (holotype), TBGT 2902 (isotype), 24.iv.2007, Kerala, Thiruvananthapuram, Karimancode, on leaves of Kleinhovia hospita L. (Sterculiaceae), G.R. Archana.

Irenopsis buettneriicola Deight. known on Buettneria sp. and Sterculia sphanoghei from Sierra Leone and Java having both straight and uncinate perithecial setae. However, Irenopsis kleinhoviae differs from it in having pale brown, smooth walled perithecial setae and shorter appressoria having entire head cells.

Irenopsis loranthicola Hosag. \& Riju, Plant Pathology \& Quarantine 1(2): 122, 2011. (Fig. 26).

Colonies epiphyllous, dense, velvety, up to $3 \mathrm{~mm}$ in diam., often confluent. Hyphae substraight, flexuous to crooked, branching opposite at acute to wide angles, loosely to closely reticulate, cells $15-23 \times 5-8 \mu \mathrm{m}$. Appressoria alternate to unilateral, antrorse, subantrorse to retrorse, 12-20 $\mu \mathrm{m}$ long; stalk cells cylindrical to cuneate, 2-7 $\mu \mathrm{m}$ long; head cells mostly entire, ovate, clavate to cylindrical, rarely angular to sublobate,

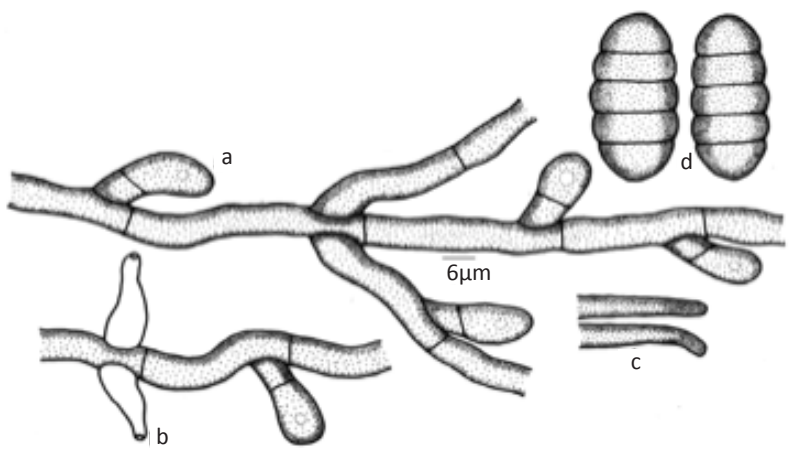

Figure 25. Irenopsis kleinhoviae

a - Appressorium; b - Phialide; c - Perithecial setae; $d$ - Ascospores
10-13×10-13 $\mu \mathrm{m}$. Phialides mixed with appressoria, opposite, alternate to unilateral, ampulliform, 12$18 \times 5-8 \mu \mathrm{m}$. Perithecia scattered, up to $130 \mu \mathrm{m}$ in diam.; perithecial setae 2-10 in number, simple, straight to uncinate at the apical portion, acute to obtuse at the tip, up to $185 \mu \mathrm{m}$ long; ascospores cylindrical to oblong, 4-septate, slightly constricted at the septa, 37-48×11$18 \mu \mathrm{m}$.

Material examined: TBGT 5068 (holotype), 03.i.2011, Kerala, Kollam, Chozhiakode, on leaves of Loranthus sp. (Loranthaceae), V.B. Hosagoudar et al. Part of the collection has been deposited in $\mathrm{HClO}$, New Delhi.

This collection showed much variation in the ascospores measurements. Many Meliola species are known on members of the family Loranthaceae but the present fungus differs from the genus Meliola in having perithecial setae. Hence, it has been accommodated in a new species of Irenopsis (Hansford 1961; Hosagoudar 1996, 2008; Hu et al. 1996, 1999).

The colonies of Irenoposis loranthi were associated with Meliola loranthacearum Hosag. \& Abraham, M. prataprajii Hosag. \& Abraham and Asterina deightonii Sydow .

Irenopsis pavoniae Hosag. \& Jacob Thomas, J. Appl. \& Nat. Sci. 2: 103, 2010. (Fig. 27).

Colonies epiphyllous, thin, up to $2 \mathrm{~mm}$ in diameter, confluent. Hyphae flexuous, branching opposite to irregular at wide angles, closely reticulate, cells 1958x4-7 $\mu \mathrm{m}$. Appressoria alternate, 5\% unilateral, antrorse to spreading, straight to variously curved, 14$19 \mu \mathrm{m}$ long; stalk cells cylindrical to cuneate, 4-10 $\mu \mathrm{m}$ long; head cells ovate to globose, entire, subangular to

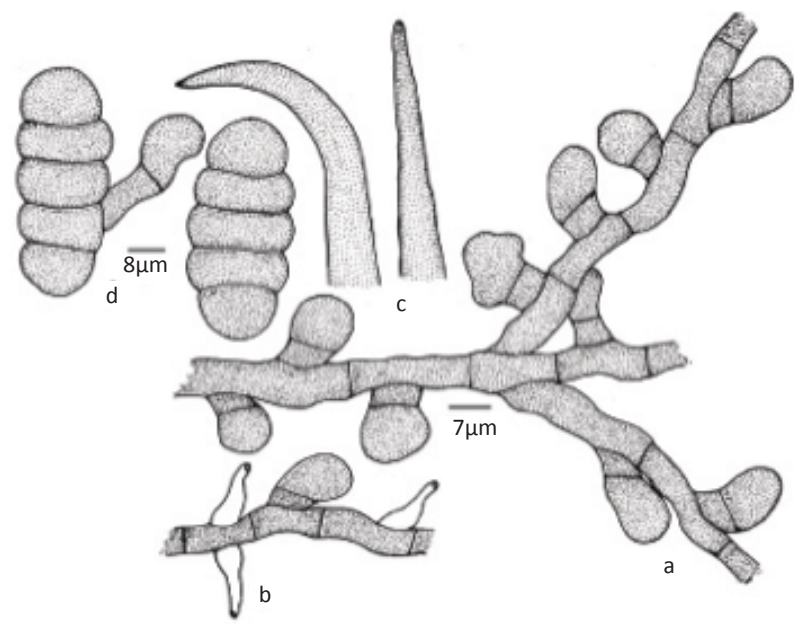

Figure 26. Irenopsis loranthicola

a - Appressorium; b - Phialide; c - Perithecial setae; $d$ - Ascospores 
sublobate, truncate, 9-11x9-12 $\mu \mathrm{m}$. Phialides mixed with appressoria, alternate to opposite, ampulliform, 14-24x4-7 $\mu \mathrm{m}$. Perithecia scattered to loosely grouped, up to $140 \mu \mathrm{m}$ in diameter; perithecial setae 10-16 in number, simple, straight, smooth, obtuse at the tip, up to $120 \mu \mathrm{m}$ long; ascospores obovoidal to ellipsoidal, 4-septate, constricted at the septa, 31-36×12-14 $\mu \mathrm{m}$.

Materials examined: HClO 49356 (holotype), TBGT 3601 (isotype), 18.xi.2007, Kerala, Thiruvananthapuram, Peppara Wildlife Sanctuary, on leaves of Pavonia sp. (Malvaceae), Jacob Thomas.

Based on the digital formula 3401.3220, flexuous to crooked hyphae and entire to sublobate apical cells of appressoria, this species is closer to Irenopsis aciculosa (Wint.) Stev., I. sidae (Rehim) Hughes (Hansford 1961). However, entire to angular head cells in contrast to lobate ones and obtuse tip of the perithecial setae are the distinguishing characters of this species.

Irenopsis pterigotae Hosag., Sabeena \& Jacob Thomas, Bioscience Discovery 2: 119, 2011. (Fig. 28).

Colonies amphigenous, thin, up to $2 \mathrm{~mm}$ in diameter, confluent. Hyphae substraight to flexuous, branching opposite to unilateral at acute to wide angles, loosely to closely reticulate, cells $17-22 \times 5-7 \mu \mathrm{m}$. Appressoria alternate, straight to curved, antrorse, subantrorse to retrorse, 15-25 $\mu \mathrm{m}$ long; stalk cells cylindrical to cuneate, 5-10 $\mu \mathrm{m}$ long; head cells globose, ovate, entire angular to sublobate, $10-15 \times 10-12 \mu \mathrm{m}$. Phialides mixed with appressoria, opposite to unilateral, ampulliform, 12$25 \times 5-7 \mu \mathrm{m}$. Perithecia scattered, up to $150 \mu \mathrm{m}$ in diam.; Perithecial setae $2-6$, simple, straight, obtuse at the

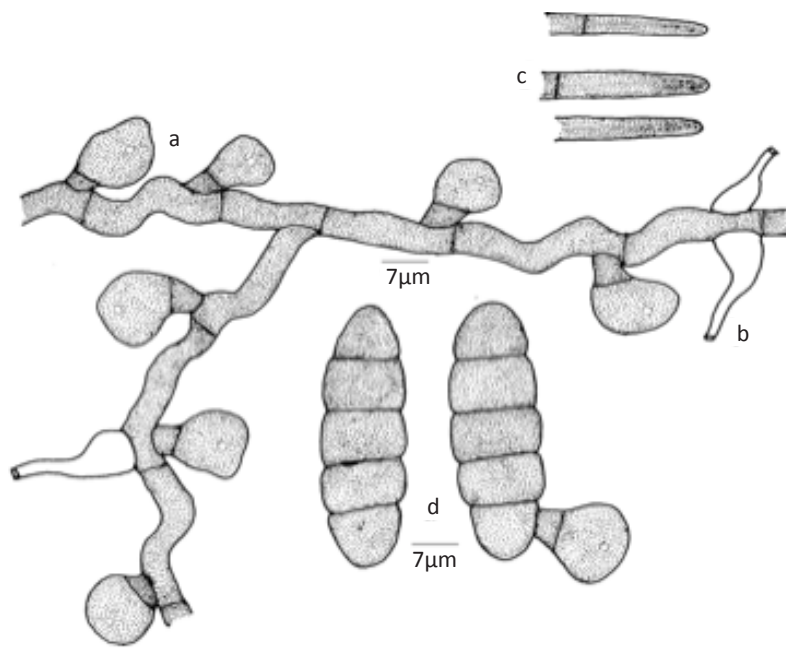

Figure 27. Irenopsis pavoniae

a - Appressorium; b - Phialide; c - Perithecial setae; $d$ - Ascospores tip, up to $120 \mu \mathrm{m}$ long; ascospores oblong to cylindrical, 4-septate, constricted at the septa 37-40×13-15 $\mu \mathrm{m}$.

Material examined: TBGT 4555 (holotype), HCIO 50638 (isotype), 16.ii.2008, Kerala, Thiruvananthapuram, Kottoor, on leaves of Pterigota alata (Roxb.) R.Br. (Sterculiaceae), Jacob Thomas.

This species is similar to I. helicteridis Hosag. and I. tjibodense Hansf. in having sublobate head cells of appressoria. However, it differs from the former in having substraight hyphae and only antrorse appressoria having entire to sublobate head cells. It differs from the latter in having predominantly angular to sublobate head cells of appressoria (Hansford 1961; Hosagoudar 1996).

Irenopsis sidae (Rehm) Hughes var. abutili Hosag., Agarwal, H. Biju \& Archana, Indian Phytopathol. 60: 82, 2007. (Fig. 29).

Colonies amphigenous, thin, up to $1 \mathrm{~mm}$ in diameter, confluent. Hyphae sub straight to flexuous, branching opposite, alternate to irregular at acute to wide angles, loosely reticulate, cells $14-34 \times 4-7 \mu \mathrm{m}$. Appressoria alternate to unilateral, antrorse, sub-antrorse to retrorse, straight to curved, 11-19 $\mu \mathrm{m}$ long; stalk cells cylindrical

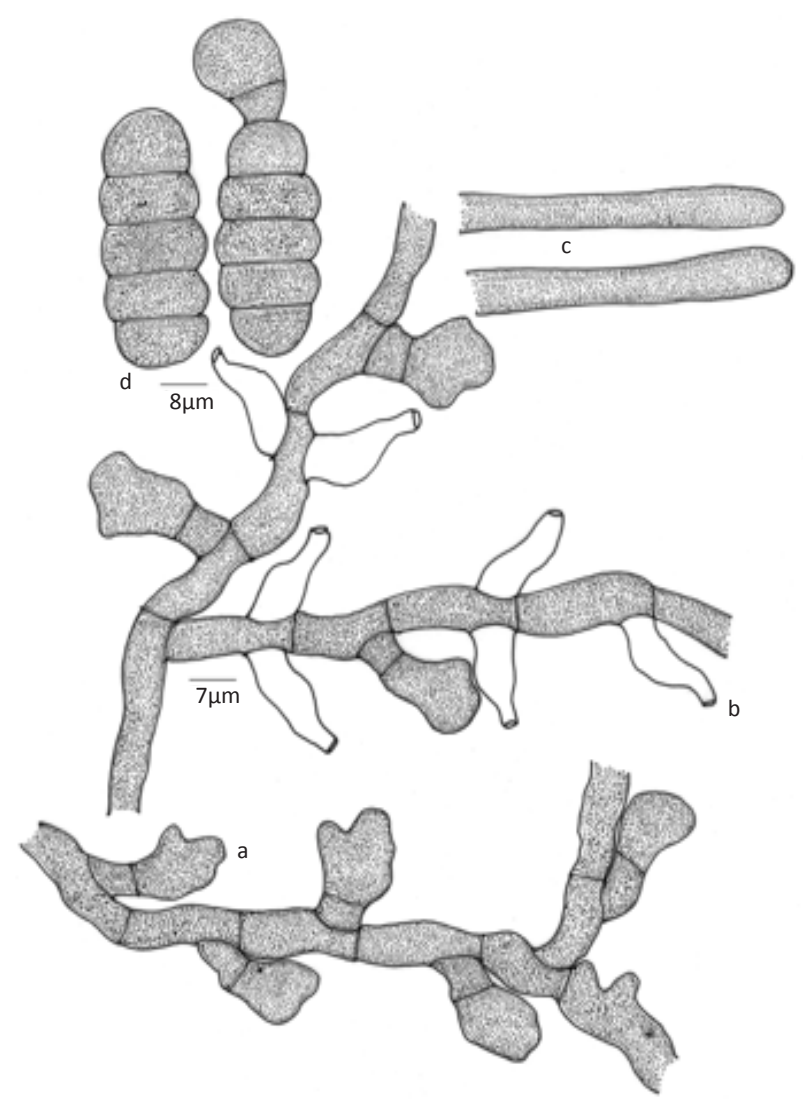

Figure 28. Irenopsis pterigotae

a - Appressorium; b - Phialide; c - Perithecial setae; $d$ - Ascospores 
to cuneate, 3-8 $\mu \mathrm{m}$ long; head cells globose, ovate, entire to sublobate, $8-11 \times 6-11 \mu \mathrm{m}$. Phialides mixed with appressoria, ampulliform, opposite, alternate to unilateral, $12-22 \times 4-8 \mu \mathrm{m}$. Perithecia globose, scattered up to $120 \mu \mathrm{m}$ in diameter, perithecial setae simple, straight to slightly curved, acute, obtuse at the tip up to $127 \mu \mathrm{m}$ long; ascospores obovoidal, 4-septate, constricted at the septa, 27-32x11-13 $\mu \mathrm{m}$.

Material examined: $\mathrm{HClO} 46340$ (holotype) TBGT 1986 (isotype), 15.xii.2004, Kerala, Pathanamthitta, Anathode dam site, on leaves of Abutilon sp. (Malvaceae), V.B. Hosagoudar et al.

This variety differs from the variety sidae in having shorter perithecial setae and smaller ascospores (Hansford 1961).

Irenopsis trichiliae Hosag. \& Riju, J. Threatened Taxa 2(4): 824, 2010. (Fig. 30).

Colonies epiphyllous, subdense, scattered, up to $2 \mu \mathrm{m}$ in diam., confluent. Hyphae straight to flexuous, branching opposite to alternate at acute to wide angles, loosely to closely reticulate, cells $11-33 \times 6-11$ $\mu \mathrm{m}$. Appressoria alternate, unilateral, antrorse to subantrorse, 13-26 $\mu \mathrm{m}$ long; stalk cells cylindrical to

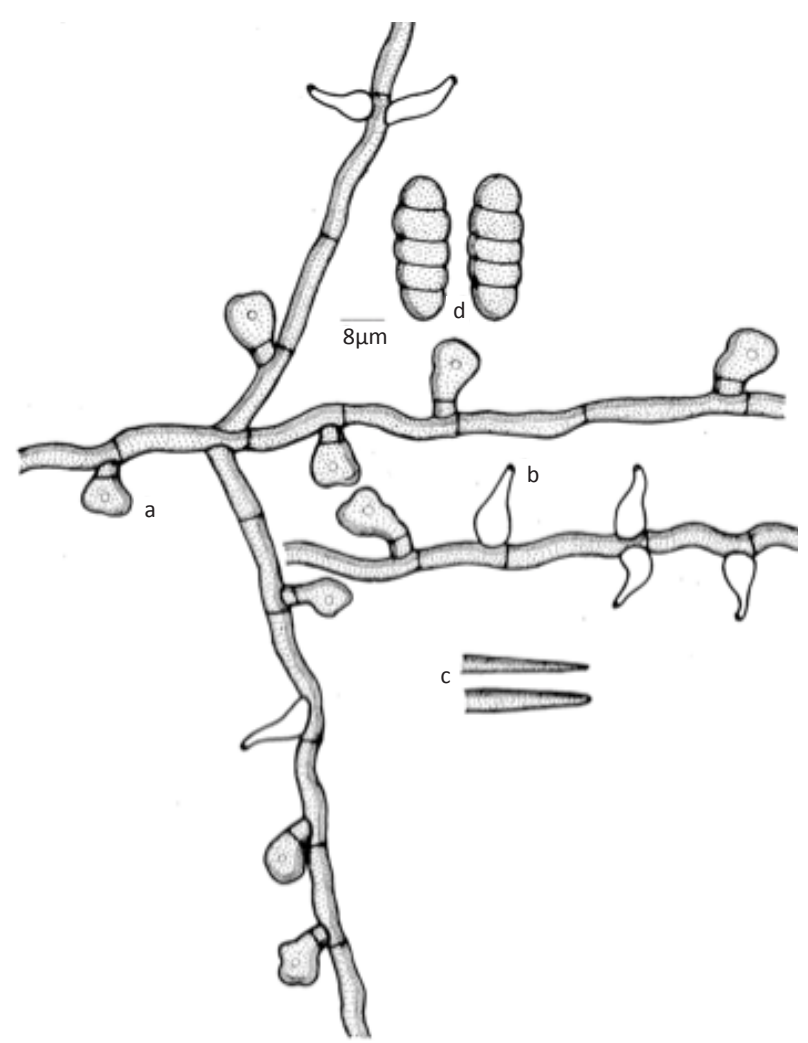

Figure 29 Irenopsis sidae var. abutili

a - Appressorium; b - Phialide; c - Perithecial setae; $d$ - Ascospores cuneate, 4-11 $\mu \mathrm{m}$ long; head cells globose, angular, sublobate to deeply globate $8-18 \times 11-18 \mu \mathrm{m}$. Phialides mixed with appressoria, opposite to unilateral, ampulliform, 17-24x6-9 $\mu \mathrm{m}$. Perithecia scattered, up to $209 \mu \mathrm{m}$ in diameter; perithecial setae $0-5$ in number, straight, simple, obtuse at the apex, up to $198 \mu \mathrm{m}$ long; ascospores cylindrical, 4-septate, slightly constricted at the septa, 37-47x15-18 $\mu \mathrm{m}$.

Materials examined: $\mathrm{HClO} 48177$ (holotype), TBGT 2913 (isotype), 10.xi.2007, Kerala, Wayanad, Padinharathara, on leaves of Trichilia sp. (Meliaceae), $16^{\text {th }}$ mile, M. C. Riju.

Irenopsis chukrasiae Hosag., I. inidica (Anahosur) Hosag., I. murrayae Hosag. \& Rajkumar are known on the members of the family Meliaceae (Hosagoudar 1996; Hosagoudar et al. 2001). Irenopsis trichiliae differs from I. chukrasiae in having only unicellular stalk cells of the appressoria and from I. indica in having straight hyphae and 0-5 perithecial setae. It also differs from $I$. murrayae in having angular to lobate head cells of the appressoria.

Irenopsis xeromphidis Hosag. \& Sabeena, Taiwania 55(3): 249, 2010. (Fig. 31).

Colonies epiphyllous, thin, up to $2 \mathrm{~mm}$ in diameter, confluent. Hyphae substraight to flexuous, branchingopposite to unilateral at acute to wide angles, loosely reticulate, cells 15-35x5-10 $\mu \mathrm{m}$. Appressoria alternate, $1 \%$ opposite to unilateral, antrorse to

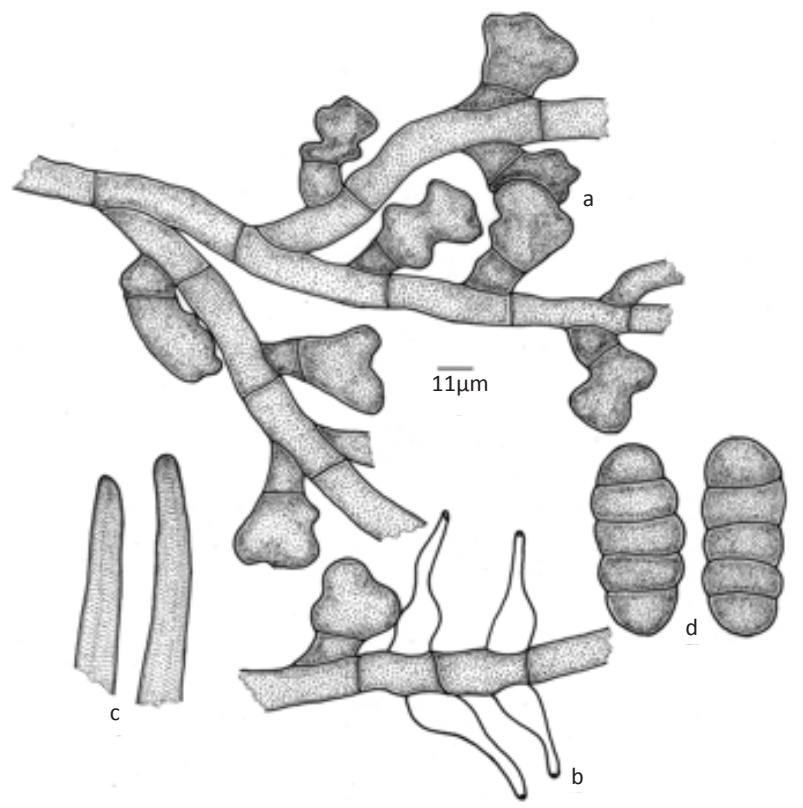

Figure 30. Irenopsis trichiliae

a - Appressorium; b - Phialide; c - Perithecial setae; $d$ - Ascospores 
subantrorse, 20-30 $\mu \mathrm{m}$ long; stalk cells cylindrical to cuneate, 5-10 $\mu \mathrm{m}$ long; head cells ovate, oblong, straight to curved, entire, angular to rarely slightly lobate, 15-20x12-15 $\mu \mathrm{m}$. Phialides mixed with appressoria, opposite to unilateral, ampulliform, 12-25x5-10 $\mu \mathrm{m}$. Perithecia scattered, up to $150 \mu \mathrm{m}$ in diameter; perithecial setae 5-8, straight to slightly curved, upright, smooth walled, broadly rounded at the tip, up to $110 \mu \mathrm{m}$ long; ascospores cylindrical to obovoidal, 4-septate, constricted at the septa, 40-45×17-20 $\mu \mathrm{m}$.

Materials examined: HCIO 49241 (holotype), TBGT 3480 (isotype), 24.ix.2008, On leaves of Xeromphis uliginosa (Thunb.) Keay (Rubiaceae), Kerala, Thiruvananthapuram, Palode, TBGRI Campus, A. Sabeena \& M.C. Riju.

Irenopsis bayamonensis Tehon var. guettardae (Cif.) Hansf. and I. chiococcae Stev. are known on the members of the family Rubiaceae. The former taxon is of doubtful nature (Hansford 1961). The present new species differs from I. chiococcae in having longer appressoria, smooth walled perithecial setae in contrast to asperulate ones and straight to curved setae in contrast to twisted.

\section{THE GENUS MELIOLA}

Meliola abdulkalamii Hosag. \& Riju, Plant Pathology \& Quarantine 1(2): 123, 2011. (Fig. 32).

Colonies epiphyllous, crustose, up to $5 \mathrm{~mm}$ in diam., scattered, confluent. Hyphae straight to flexuous, branching opposite at acute to wide angles, loosely to closely reticulate, cells $20-33 \times 5-8 \mu \mathrm{m}$. Appressoria alternate, unilateral, antrorse to subantrorse, 17-20 $\mu \mathrm{m}$ long; stalk cells cylindrical to cuneate, $5-8 \mu \mathrm{m}$ long; head cells globose, subglobose, entire, 7-10×7-13 $\mu \mathrm{m}$. Phialides mixed with appressoria, mostly opposite,

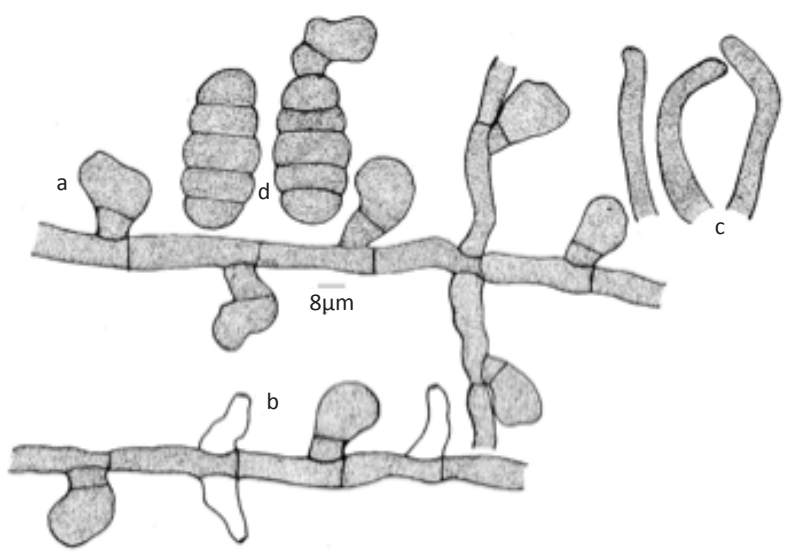

Figure 31. Irenopsis xeromphidis

a - Appressorium; b - Phialide; c - Perithecial setae; $d$ - Ascospores rarely alternate, ampulliform, 12-18×7-8 $\mu \mathrm{m}$. Mycelial setae simple, straight, obtuse, clavate, inflated, notched to bifid at the apex, ends broadly rounded, up to $320 \mu \mathrm{m}$ long. Perithecia up to $230 \mu \mathrm{m}$ in diam.; ascospores cylindrical to oblong, 4-septate, slightly constricted at the septa, 27-33×10-13 $\mu \mathrm{m}$.

Materialexamined:TBGT4958(holotype), $\mathrm{HClO} 51041$ (isotype), 14.vi.2009, Kerala, Wayanad, Padinharathara, $16^{\text {th }}$ mile, on leaves of Aralia sp. (Araliaceae), M.C. Riju.

The present species different from other Meliola species known on members of Araliaceae in having broadly obtuse, inflated to bifid tips of the mycelial setae (Hansford 1961, Hosagoudar 1996, 2008, Hu et al. 1996, 1999).

Meliola abri Hosag. \& Riju, Plant Pathology \& Quarantine 1(2): 124, 2011. (Fig. 33)

Colonies epiphyllous, thin, scattered, up to $3 \mathrm{~mm}$ in diam. Hyphae flexuous to crooked, branching opposite at wide angles, loosely reticulate, cells $17-30 \times 5-8 \mu \mathrm{m}$. Appressoria alternate to unilateral, up to $1 \%$ opposite, antrorse, subantrorse to retrorse, 17-20×10-13 $\mu \mathrm{m}$; stalk cells cylindrical to cuneate, $2-3 \mu \mathrm{m}$ long; head cells globose, ovate, straight to curved, 12-15×10-13 $\mu \mathrm{m}$. Phialides mixed with appressoria, opposite to unilateral, ampuliform, 20-25×5-8 $\mu \mathrm{m}$. Mycelial setae scattered to grouped around perithecia, simple, straight, acute at the tip, up to $360 \mu \mathrm{m}$ long. Perithecia scattered, up to $130 \mu \mathrm{m}$ in diam.; ascospores cylindrical, 4-septate, constricted at

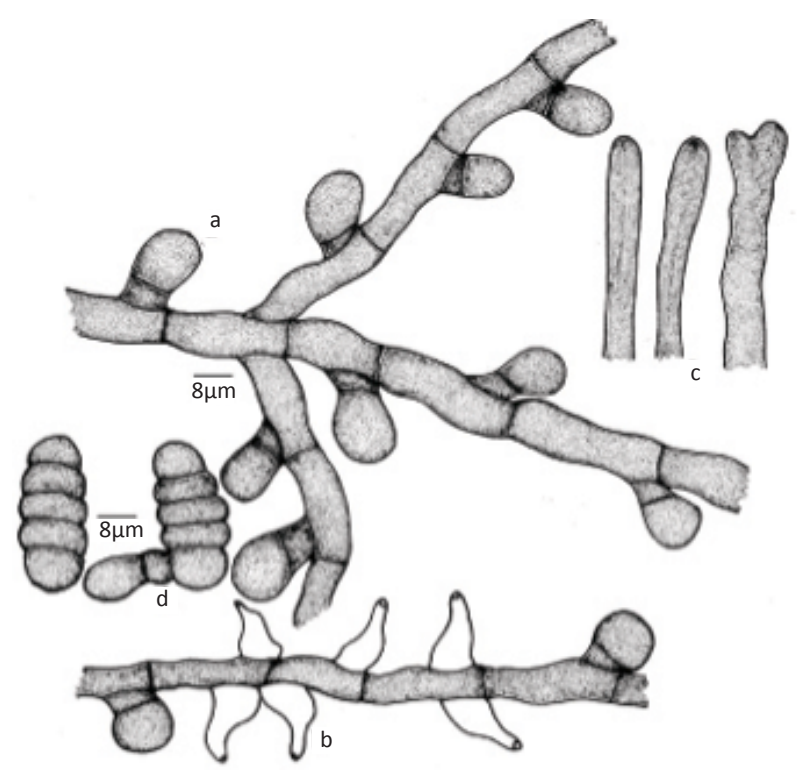

Figure 32. Meliola abdulkalamii

a - Appressorium; b - Phialide; c - Apical portion of mycelial setae; d-Ascospores 
the septa, 30-33×10-13 $\mu \mathrm{m}$.

Material examined: TBGT 5070 (holotype), 16.i.2011, Kerala, Wayanad, Padinharathara, on leaves of Abrus pulchellus Wallich ex Thwaites (Fabaceae), M.C. Riju. Part of the collection has been deposited in $\mathrm{HClO}$, New Delhi.

Meliola bicornis Wint. is known on Abrus canescens from Sierra Leone (Hansford 1961), but this is a complex species and Hansford (1961) has segregated more thanhundred species. Based on the simple setae and smaller ascospores, we prefer to accommodate our collection in a new species.

Meliola abrupta Sydow, Ann. Mycol. 15: 181, 1917; Hansf., Sydowia Beih. 2: 292, 1961; Hosag., Jacob Thomas \& Agarwal, Taprobanica 3(1): 42, 2011. Meliola derridis Yates, Philippine J. Sci. 13: 368, 1918. (Fig. 34).

Colonies amphigenous, mostly epiphyllous, dense, velvety, up to $2 \mathrm{~mm}$ in diameter, confluent and covering entire upper surface of the leaves. Hyphae straight to substraight, branching mostly opposite at acute to wide angles, loosely to closely reticulate, cells $14-38 \times 4-7 \mu \mathrm{m}$. Appressoria alternate, about 5\% opposite, antrorse, curved, 12-17 $\mu \mathrm{m}$ long; stalk cells cylindrical to cuneate, 2-5 $\mu \mathrm{m}$ long; head cells globose to subglobose, straight to curved, entire, 9-14x7-12 $\mu \mathrm{m}$. Phialides mixed with appressoria, alternate to opposite, ampulliform, 16-29x6-12 $\mu \mathrm{m}$. Mycelial setae numerous, scattered, straight, simple, acute to dentate at the tip, up to $520 \mu \mathrm{m}$ long. Perithecia scattered, verrucose, globose, up to $160 \mu \mathrm{m}$ in diameter; ascospores cylindrical to ellipsoidal, 4-septate, constricted, 36-43×12-17 $\mu \mathrm{m}$.

Materials examined: HClO 49034, TBGT 3289,

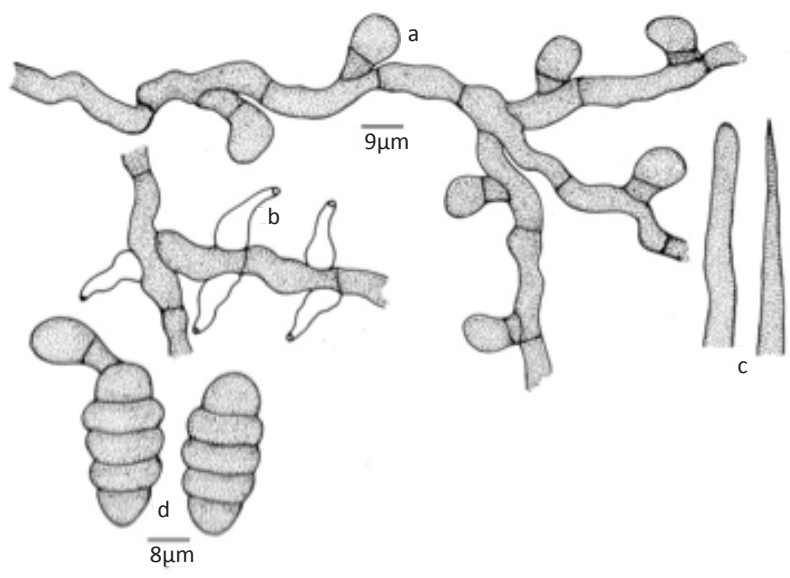

Figure 33. Meliola abri

a - Appressorium; b - Phialide; c - Apical portion of mycelial setae; d - Ascospores

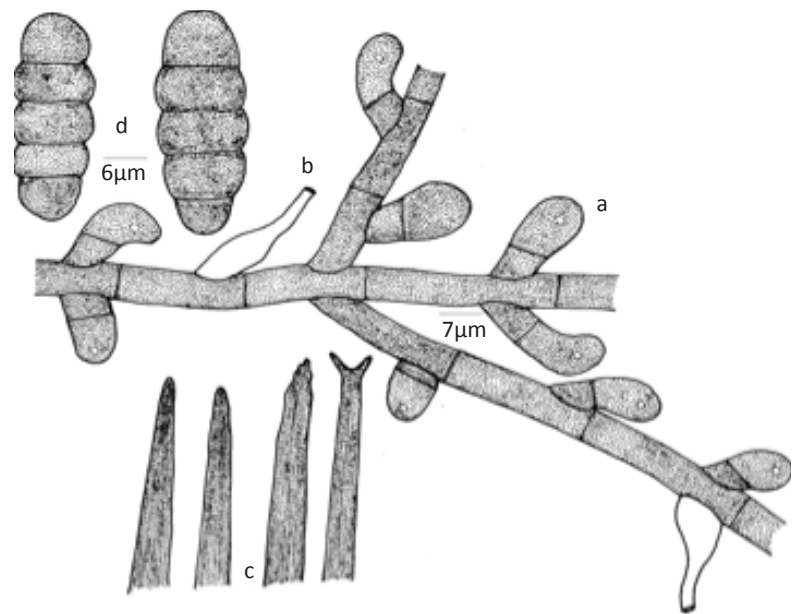

Figure 34. Meliola abrupta

a - Appressorium; b - Phialide; c - Apical portion of mycelial setae; $d$ - Ascospores

18.xi.2007, Kerala, Thiruvananthapuram, Peppara Wildlife Sanctuary, near Peppara Dam, on leaves of Derris sp. (Fabaceae), Jacob Thomas.

This is the only species known on this from India (Hosagoudar 1996, 2008).

Meliola aganopes Hosag., Jacob Thomas \& Agarwal, Nelumbo 52: 3, 2010. (Fig. 35).

Colonies epiphyllous, subdense, crustose, up to 4 $\mathrm{mm}$ in diameter, confluent. Hyphae straight, branching opposite at acute to subacute angles, loosely reticulate, cells $24-46 \times 4-7 \mu \mathrm{m}$. Appressoria alternate, about $1 \%$ opposite, antrorse to spreading, straight to curved, 14$19 \mu \mathrm{m}$ long; stalk cells cylindrical to cuneate, $2-5 \mu \mathrm{m}$ long; head cells ovate to oblong, entire, rounded at the apex, 9-15x7-10 $\mu \mathrm{m}$. Phialides mixed with appressoria, alternate to opposite, ampulliform, $14-22 \times 6-8 \mu \mathrm{m}$. Mycelial setae fairly numerous, scattered, straight, simple, acute to dentate at the tip, up to $740 \mu \mathrm{m}$ long. Perithecia scattered, verrucose, up to $170 \mu \mathrm{m}$ in diam.; ascospores cylindrical to oblong, 4-septate, constricted at the septa, 33-38x12-15 $\mu \mathrm{m}$.

Materials examined: HCIO 49016 (holotype), TBGT 3271 (isoype), 21.viii.2007, Kerala, Thrissur, Vazhachal, on leaves of Aganope thyrsiflora (Benth.) Polh. (Fabaceae), Jacob Thomas et al.

Based on the digital formula $31^{1} / 3$ 3.3223, Meliola aganopes is similar to M. teramni var. millettiae Hosag. reported on Millettia rubiginosa from the Western Ghats region of Tamil Nadu (Hosagoudar \& Goos, 1991; Hosagoudar 1996). However, Meliola aganopes differs from it in having typically ovate to oblong head cells of 


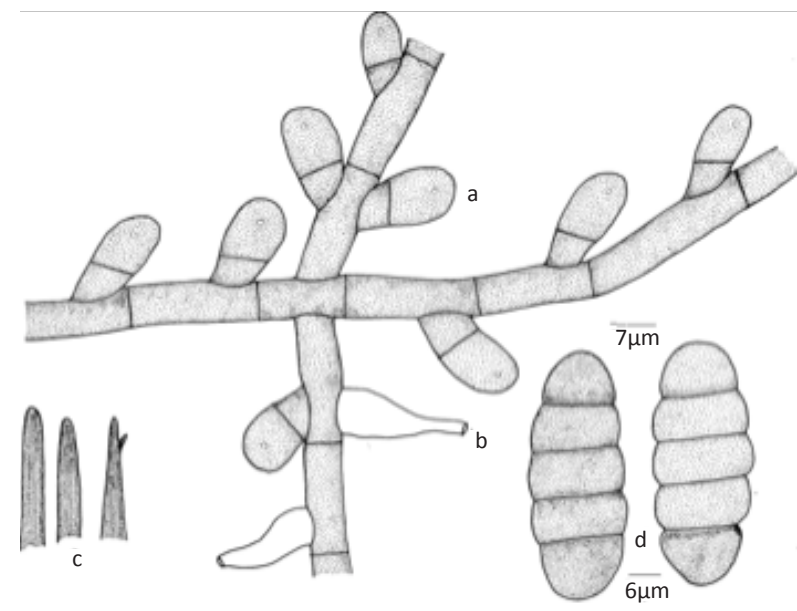

Figure 35. Meliola aganopes

a - Appressorium; b - Phialide; c - Apical portion of mycelial setae; d - Ascospores

appressoria with appreciable number of mycelial setae.

Meliola ailanthicola Hosag. \& Riju, J. Threatened Taxa 2(4): 824, 2010. (Fig. 36).

Colonies hypophyllous, thin, up to $4 \mathrm{~mm}$ in diam., confluent. Hyphae crooked, branching alternate to opposite at acute to wide angles, loosely to closely reticulate, cells $13-33 \times 4-9 \mu \mathrm{m}$. Appressoria alternate to unilateral, straight to curved, antrorse, subantrorse to retrorse, $13-27 \mu \mathrm{m}$ long; stalk cells cylindrical to cuneate, 4-16 $\mu \mathrm{m}$ long; head cells ovate, globose, truncate to slightly lobate, 8-13x6-9 $\mu \mathrm{m}$. Phialides mixed with appressoria, opposite, alternate to unilateral, ampulliform, 13-22x4-9 $\mu \mathrm{m}$. Mycelial setae scattered, simple, straight, acute, obtuse to $2-5$ dentate at the tip, up to $400 \mu \mathrm{m}$ long. Perithecia scattered, up to $160 \mu \mathrm{m}$ in diam.; ascospores obovoidal, 4-septate, slightly constricted at the septa, 37-44×13-16 $\mu \mathrm{m}$.

Materials examined: HClO 48170 (holotype), TBGT 2906 (isotype); HCIO 48173, TBGT 2909, 30.ix.2007, Kerala, Wayanad, $16^{\text {th }}$ mile, Padinharathara, on leaves of Ailanthus malabarica (Dennst.) Alston (Simaroubaceae), M. C. Riju.

This species differs from Meliola ailanthi Sharma et al. emend. Hosag. in having strongly appressed colonies on the lower surface of the leaves and having distinctly crooked mycelium (Hosagoudar 1996).

Meliola alangii var. salvifolii Hosag. \& Sabeena, Zoos, Print J. 22:2786, 2007. (Fig. 37)

Colonies epiphyllous, thin, up to $4 \mathrm{~mm}$ in diameter, confluent. Hyphae substraight to undulating, branching mostly opposite at acute angles, loosely reticulate, cells

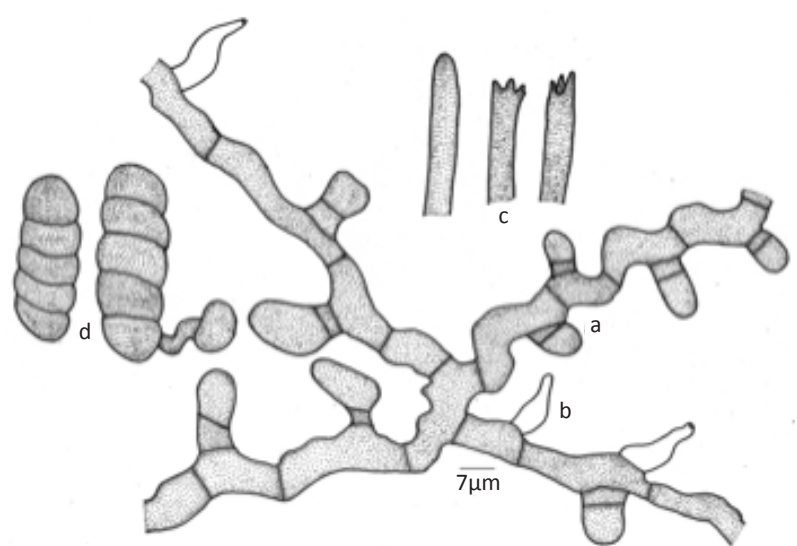

Figure.36. Meliola ailanthicola

a - Appressorium; b - Phialide; c - Apical portion of mycelial setae; d - Ascospores

24-29x4-8 $\mu \mathrm{m}$. Appressoria alternate, 30\% opposite, antrorse, subantrorse to retrorse, 16-19 $\mu \mathrm{m}$ long; stalk cells cylindrical to cuneate, 3-8 $\mu \mathrm{m}$ long; head cells cylindrical, oblong, globose, ovoid, broadly rounded to truncate and often narrowed towards its apex, entire, 11-13x8-10 $\mu \mathrm{m}$. Phialides mixed with appressoria, alternate to opposite, ampulliform, $12-24 \times 6-8 \mu \mathrm{m}$. Mycelial setae numerous, scattered, simple, straight, acute to obtuse at the tip, up to $500 \mu \mathrm{m}$ long. Perithecia globose, scattered, up to $140 \mu \mathrm{m}$ in diam.; ascospores cylindrical to oblong, 4-septate, constricted at the septa, 33-37x12-16 $\mu \mathrm{m}$.

Material examined: $\mathrm{HClO} 47493$ (holotype), TBGT 2531 (isotype), 16.x.2006, Kerala, Kozhikode, in the Malabar Botanic Garden, on leaves of Alangium salvifolium (L.f.) Wagerin (Alangiaceae), A. Sabeena et al.

Meliola alangii Sydow is the only Meliola species known on the members of the family Alangiaceae (Hansford 1961; Hosagoudar 1996, Hosagoudar et al. 1997). However, variety salvifolii differs from the var. alangii in having $30 \%$ opposite appressoria.

Meliola aporusae Hosag. \& Robin, Bioscience Discovery 2(2): 265, 2011. (Fig. 38).

Colonies amphigenous, mostly hypophyllous, crustose, up to $4 \mathrm{~mm}$ in diameter, confluent. Hyphae straight to substraight, branching mostly opposite to alternate at acute angles, loosely reticulate, cells 1924x5-7 $\mu \mathrm{m}$. Appressoria alternate, about $15 \%$ opposite, antrorse to subantrorse, spreading, 24-29 $\mu \mathrm{m}$ long; stalk cells cylindrical to cuneate, 10-12 $\mu \mathrm{m}$ long; head cells ovate, clavate, globose, entire to 2-5-times lobate, often slightly angular, 12-19x14-19 $\mu \mathrm{m}$. Phialides mixed with 


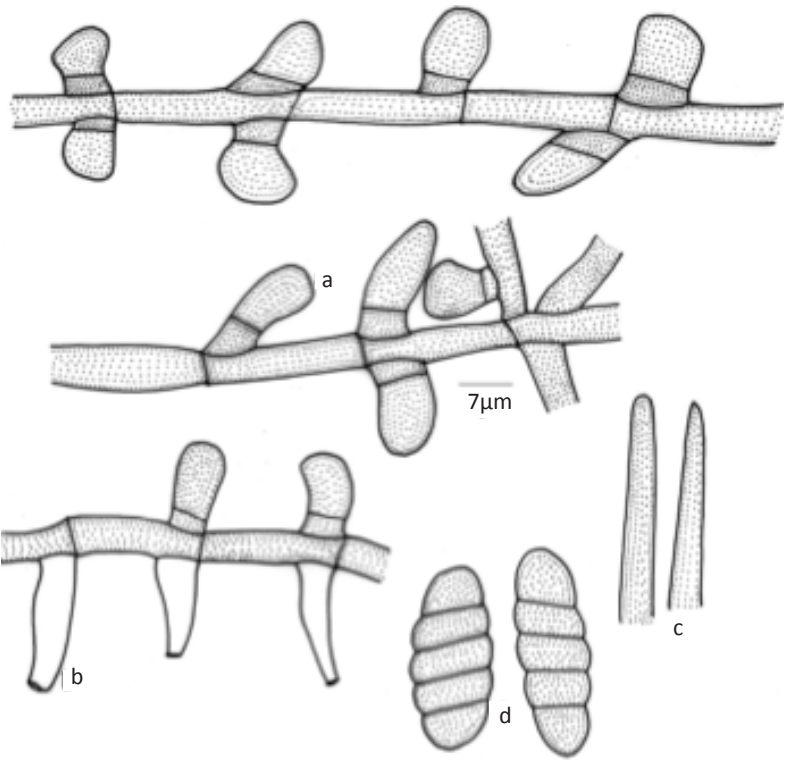

Figure 37. Meliola alangii var. salvifolii

a - Appressorium; b - Phialide; c - Apical portion of mycelial setae; d - Ascospores

appressoria, alternate, ampulliform, 17-24x7-10 $\mu \mathrm{m}$. Mycelial setae few, simple, straight, obtuse at the tip, up to $410 \mu \mathrm{m}$ long. Perithecia scattered, up to $115 \mu \mathrm{m}$ in diam.; ascospores ellipsoidal, 4-septate, constricted at the septa, 41-43×14-17 $\mu \mathrm{m}$.

Materials examined: TBGT 4652 (holotype), HCIO 50735 (isotype), 25.iv.2007, Kerala, Kottayam, Ponthanpuzha, Placherry, on leaves of Aporusa sp. (Euphorbiaceae), P.J. Robin et al.; HCIO 50925, TBGT 4842, 23.xii2008, Wayanad, Banasur mala, on leaves of Aporusa sp., M.C. Riju.

Based on the digital formula, the present new species is close to Meliola goleoria Hansf. and M. tetrorchidiicola Hansf. known on Galeario filiformis and Tetrorchidium rubivenium from Java and Brazil, respectively. However, differs from both in having stellately lobate head cells of the appressoria (Hansford 1961). Based on the lobate head cells, it can be compared with M. octephilae Hosag. et al. but differs from it in having only $15 \%$ opposite appressoria with stellately lobate head cells (Biju et al. 2005; Hosagoudar 2008; Hosagoudar \& Agarwal 2008).

Meliola ardisiigena Hosag., Sabeena \& Robin, Bioscience Discovery 2: 120, 2011. (Fig. 39).

Colonies hypophyllous, subdense to dense, up to $3 \mathrm{~mm}$ in diameter, confluent. Hyphae substraight, branching opposite to unilateral at acute to wide angles, loosely to closely reticulate, cells $15-30 \times 5-7 \mu \mathrm{m}$. Appressoria alternate, up to $30 \%$ opposite to unilateral, antrorse to

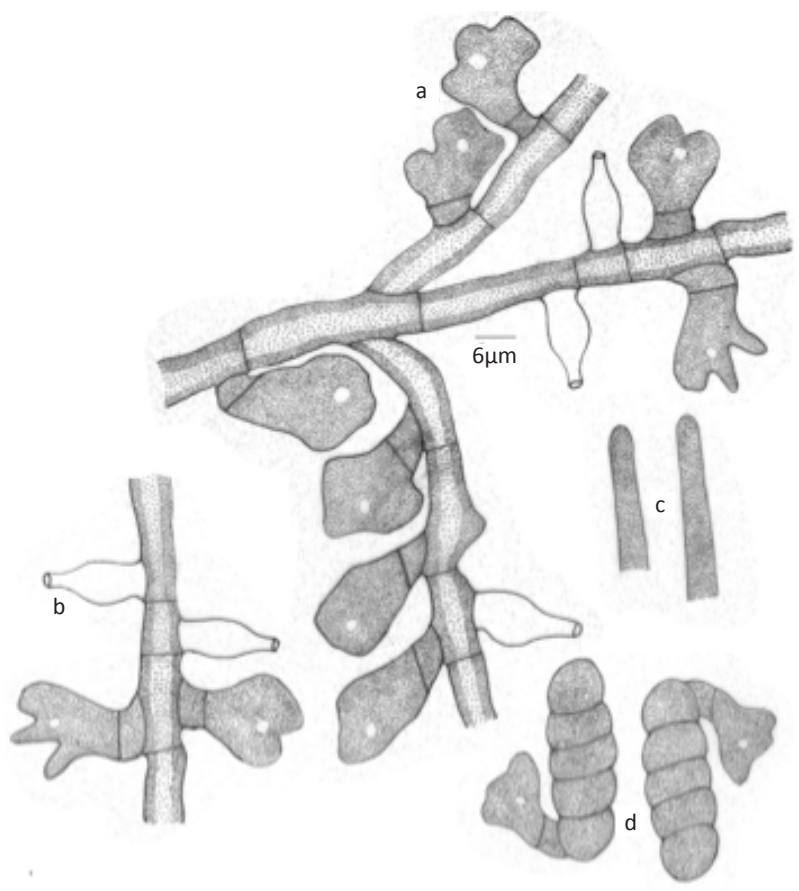

Figure 38. Meliola aporusae

a - Appressorium; b - Phialide; c - Apical portion of mycelial setae; $\mathrm{d}$ - Ascospores

subantrorse, 12-22 $\mu \mathrm{m}$ long; stalk cells cylindrical to cuneate, 2-7 $\mu \mathrm{m}$ long; head cells ovate, globose, entire, 10-17x7-12 $\mu \mathrm{m}$. Phialides mixed with appressoria, alternate to opposite, ampulliform, $12-25 \times 5-10 \mu \mathrm{m}$. Mycelial setae simple, straight, acute to obtuse at the tip, up to $350 \mu \mathrm{m}$ long. Perithecia scattered, up to $200 \mu \mathrm{m}$ in diam.; ascospores elliptic, 4-septate, constricted at the septa, 42-57x12-15 $\mu \mathrm{m}$.

Material examined: TBGT 4556 (holotype), $\mathrm{HClO}$ 50639 (isotype), 27.ix.2008, Kerala, Wyanadu, Pulpally, on leaves of Ardisia sp. (Myrsinaceae), Robin et al.

Meliola ardisiicola Hosag. et al. is known on Ardisia missionis from the high ranges of Western Ghats (Hosagoudar 2008). However, the present new species differs from it in having longer and 30\% opposite appressoria and longer ascospores.

\section{Meliola arippaensis sp. nov. Hosag. \& Sabeena}

(Fig. 40; MycoBank 803909)

Colonies hypophyllous, subdense to dense, up to $2 \mathrm{~mm}$ in diameter, confluent. Hyphae substraight, branching opposite to unilateral at acute to wide angles, loosely to closely reticulate, cells $22-32 \times 5-7 \mu \mathrm{m}$. Appressoria alternate to unilateral, $1 \%$ opposite, antrorse to subantrorse, 20-30 $\mu \mathrm{m}$ long; stalk cells cylindrical to cuneate, 5-10 $\mu \mathrm{m}$ long; head cells ovate, oblong, 


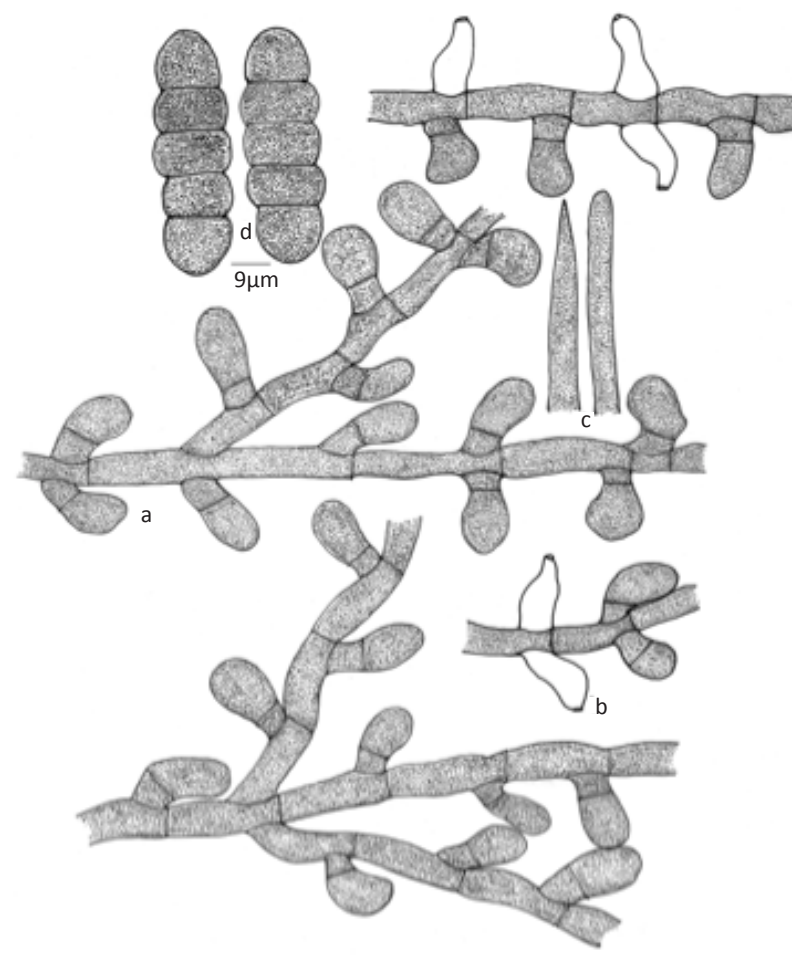

Figure 39. Meliola ardisiigena

a - Appressorium; b - Phialide; c - Apical portion of mycelial setae; d - Ascospores

globose, entire, 12-20x10-15 $\mu \mathrm{m}$. Phialides mixed with appressoria, opposite, ampulliform, 12-25x7-10 $\mu \mathrm{m}$. Mycelial setae are of two types: setae on mycelia are scattered, simple, straight, acute to obtuse at the tip, up to $1200 \mu \mathrm{m}$ long and setae grouped around perithecia are simple, straight to curved, uncinate, up to $260 \mu \mathrm{m}$ long, acute, obtuse to dentate at the tip. Perithecia scattered, up to $180 \mu \mathrm{m}$ in diam.; ascospores cylindrical to oblong, 4-septate, constricted at the septa, 47-57x20-22 $\mu \mathrm{m}$.

Materials examined: TBGT 5748 (holotype), 3.i.2011, Kerala, Kollam, Arippa, on leaves of Flacourtia sp. (Flacourtiaceae), V.B. Hosagoudar et al. Part of the collection has been deposited in $\mathrm{HClO}$, New Delhi.

Etymology: Named after the collection locality.

This species stands distinct from the Meliola species reported on the members of Flacourtiaceae in possessing shorter and straight to uncinate mycelial setae (Hansford 1961; Hosagoudar 1996, 2008; Hu et al., 1996, 1999).

Meliola aristolochigena Hosag. \& Archana, J. Threatened Taxa 1: 348, 2009. (Fig. 41).

Colonies epiphyllous, thin to dense, up to $2 \mathrm{~mm}$ in diam. Hyphae substraight to flexuous, branching alternate, opposite to irregular at acute to wide angles, loosely to closely reticulate, cells $12-16 \times 8-10 \mu \mathrm{m}$.

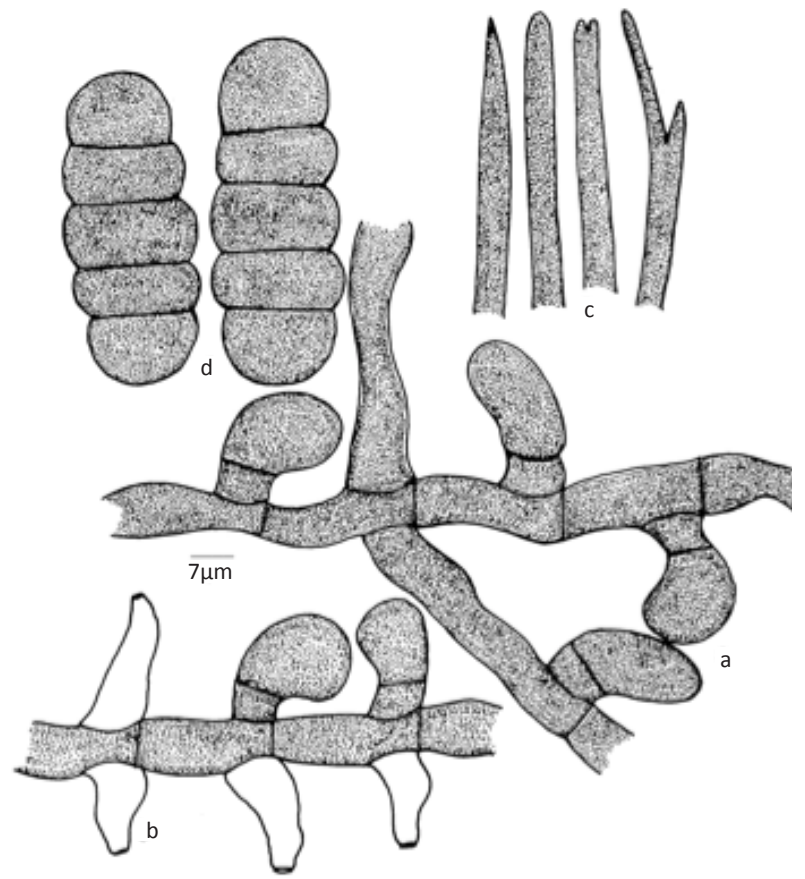

Figure 40. Meliola arippaensis sp. nov.

a - Appressorium; b - Phialide; c - Apical portion of mycelial setae; $\mathrm{d}$ - Ascospores

Appressoria alternate to about 3\% opposite, antrorse to subantrorse, 14-20 $\mu \mathrm{m}$ long; stalk cells cylindrical to cuneate, 3-7 $\mu \mathrm{m}$ long; head cells ovate to globose, entire, 11-13x9-13 $\mu \mathrm{m}$. Phialides mixed with appressoria, alternate to opposite, ampulliform, 16-20x8-10 $\mu \mathrm{m}$. Mycelial setae scattered, simple, straight, acute to obtuse at the tip, up to $540 \mu \mathrm{m}$ long. Perithecia scattered, up to $120 \mu \mathrm{m}$ in diam.; ascospores oblong to cylindrical, 4-septate, constricted at the septa, 35-40×12-14 $\mu \mathrm{m}$.

Material examined: HCIO 46237 (holotype), TBGT 1649 (isotype), 13.xii.2003, Kerala, Palghat, Silent Valley, Sairandhri, on leaves of Aristolochia tagala Cham. (Aristolochiaceae), V.B. Hosagoudar et al.; HClO 46033, TBGT 1796, 14.xii.2004, Mozhiar Forest, Pathanamthitta, Kerala, V.B. Hosagoudar et al.; Sairandhri, Silent Valley, Palghat, Kerala, $\mathrm{HClO}$ 46376, TBGT 2022; $\mathrm{HClO}$ 46378, TBGT 2024, 15.xii.2003, V.B.Hosagoudar et al.; Aristolochia grandiflora Sw., Wayanad, Periya, Gurukulam Botanic Garden, HClO 50362, TBGT 4279, 5.xi.2009, A. Sabeena \& M.C. Riju.

Having opposite appressoria, Meliola aristolochigena can be compared with $M$. catharinensis Hansf. reported on Aristolochia triangularis from Brazil (Hansford 1961). However, differs from it in having distinctly longer appressoria (14-20 $\mu \mathrm{m}$ against 11-15 $\mu \mathrm{m}$ ) and mycelial setae $(540 \mu \mathrm{m}$ against $230 \mu \mathrm{m})$. 


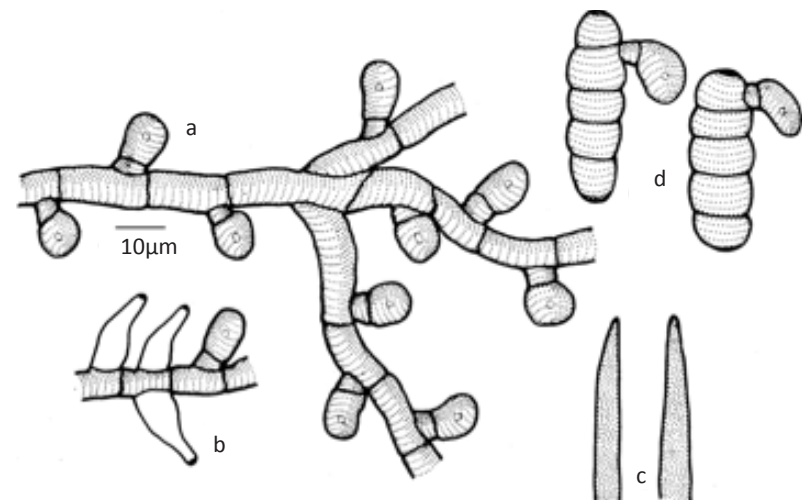

Figure 41. Meliola aristolochigena

a - Appressorium; b - Phialide; c - Apical portion of mycelial setae; d - Ascospores

Meliola arkevermae Hosag. \& Sabeena, Plant pathology \& Quarantine 3(1): 11, 2012. (Fig. 42).

Colonies epiphyllous, subdense, up to $4 \mathrm{~mm}$ in diameter, confluent. Hyphae straight to substraight, branching opposite to irregular at acute to wide angles, loosely to closely reticulate, cells $17-30 \times 5-7 \mu \mathrm{m}$. Appressoria arranged closely by leaving an intermittent gap, part of the mycelium literally devoid of appressoria, opposite, antrorse to subantrorse, closely arranged on the hyphae, 17-25 $\mu \mathrm{m}$ long; stalk cells cylindrical to cuneate, 2-7 $\mu \mathrm{m}$ long; head cells oblong, ovate, entire, angular to sublobate, 12-17x12-17 $\mu \mathrm{m}$. Phialides mixed with appressoria, opposite, ampulliform, 15-27x5-12 $\mu \mathrm{m}$. Mycelial setae numerous, scattered, simple, straight, acute to obtuse at the tip, up to $950 \mu \mathrm{m}$ long. Perithecia scattered, up to $160 \mu \mathrm{m}$ in diam. Ascospores cylindrical, 4-septate, constricted at the septa, 37-45×12-17 $\mu \mathrm{m}$.

Materials examined: TBGT 5732 (holotype), 10.xi.2007, India, Kerala, Kottayam, Ponthanpuzha, Valiyakavu, on leaves of Meliaceae member, P.J. Robin. Part of the collection has been deposited in $\mathrm{HClO}$, New Delhi.

Meliola dysoxyli Hansf., M. amoora Yates, $M$. opposita Sydow, M. opposita Sydow var. africana Hansf., M. aglaiana Hansf. and $M$. ekebergiae Hansf. are known on the members of Meliaceae having opposite appressoria. Of these, the present species is similar to $M$. dysoxyli and as M. opposita Sydow var. africana Hansf. in having densely arranged appressoria. However, Meliola arkevarmae differs from both in possessing intermittently densely arranged appressoria by leaving a gap or by leaving the mycelium free from appressoria (Hansford 1961, 1963).

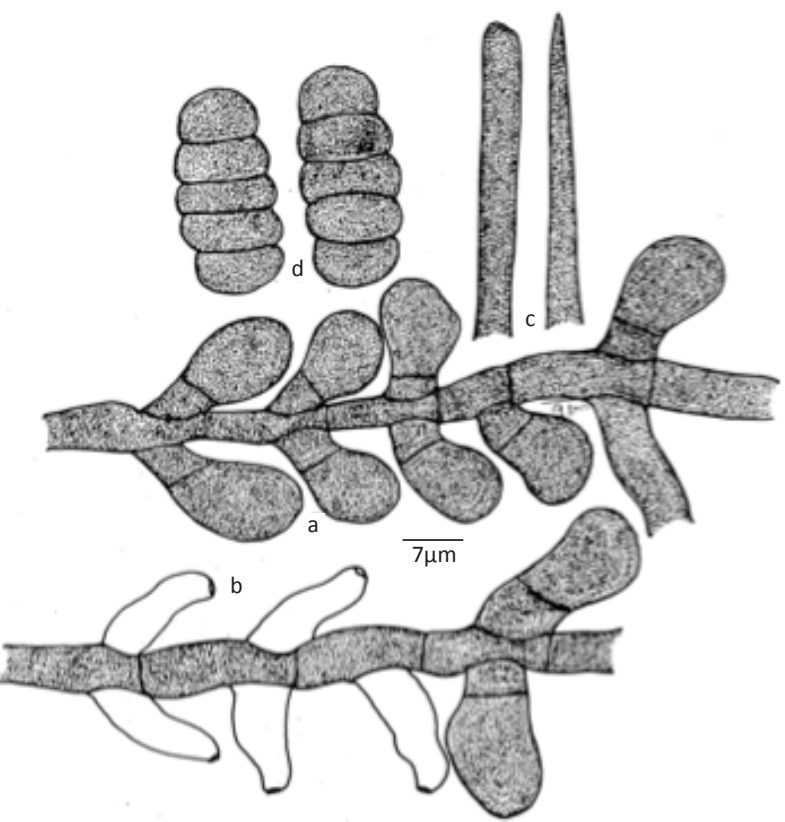

Figure 42. Meliola arkevermae

a - Appressorium; b - Phialide; c - Apical portion of mycelial setae; d - Ascospores

Meliola bakeri Sydow, Ann. Mycol. 14: 335, 1916; Hansf. Sydowia Beih.2: 374, 1961; Hosag., Jacob Thomas and Agarwal, Taprobanica 3(1): 42, 2011. (Fig. 43)

Colonies epiphyllous, scattered, up to $2 \mathrm{~mm}$ in diameter. Hyphae straight to undulate, branching opposite at acute angles, closely reticulate, cells 1724x4-7 $\mu \mathrm{m}$. Appressoria alternate to opposite, antrorse to subantrorse, retrorse to spreading, 17-20 $\mu \mathrm{m}$ long; stalk cells cuneate, 4-7 $\mu \mathrm{m}$ long; head cells ovate, globose, entire, 13-16x8-11 $\mu \mathrm{m}$. Phialides mixed with appressoria, alternate to opposite, ampulliform, 1924x4-7 $\mu \mathrm{m}$. Mycelial setae straight, simple, acute to obtuse at the tip, up to $580 \mu \mathrm{m}$ long. Perithecia scattered, verrucose, up to $128 \mu \mathrm{m}$ in diam.; ascospores obovoidal, 4-septate, constricted, 30-38x13-16 $\mu \mathrm{m}$.

Materials examined: HClO 48261, TBGT 3000, 19.xi.2006, Kerala, Pathanamthitta, Thiruvalla, on leaves of Cayrtia pedata (Lam.) A.L. Juss ex Gagnepain (Vitaceae), Jacob Thomas; HClO 49143, TBGT 3398, 6.xi.2008, Karnataka, Bhagamandala, on leaves of Vitaceae member, V.B. Hosagoudar et al.; TBGT 5358, 26.xi.2008, C. Jagath.

Meliola bauhiniicola Yamam. var. brevipoda Hosag. \& Sabeena in Hosag. \& Archana, Foliicolous fungal flora of Palode forest range, Thiruvananthapuram, Kerala, p. 99, 2012. (Fig. 44)

Colonies epiphyllous, thin up to $2 \mathrm{~mm}$ in diameter. 


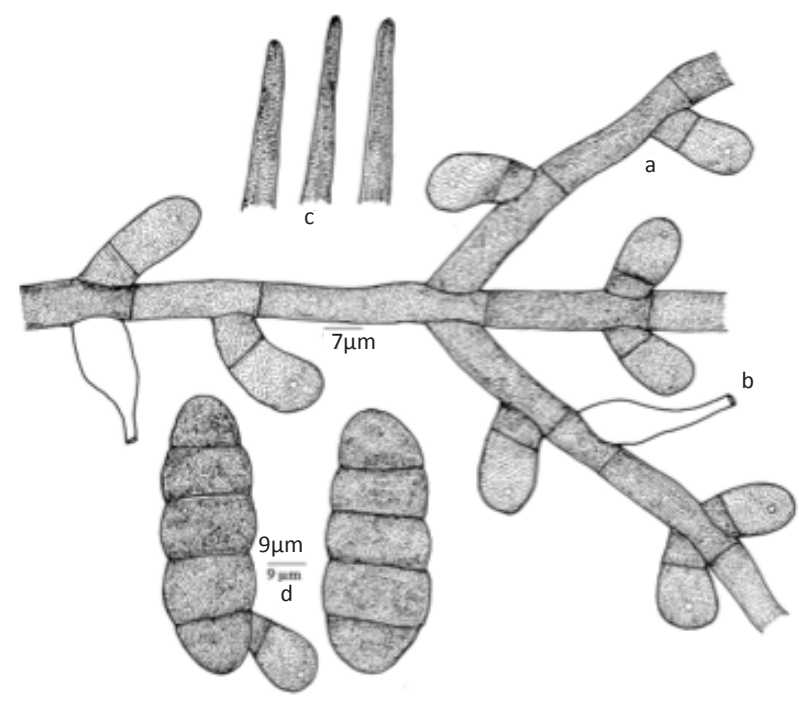

Figure 43. Meliola bakeri

a - Appressorium; b - Phialide; c - Apical portion of mycelial setae; d - Ascospores

Hyphae substraight to undulating, branching opposite to unilateral at acute to wide angles, loosely reticulate, cells 24-33x4-6 $\mu \mathrm{m}$. Appressoria opposite, alternate to unilateral, antrorse, subantrorse to retrorse, 9-14 $\mu \mathrm{m}$ long; stalk cells cylindrical to cuneate, 2-5 $\mu \mathrm{m}$ long; head cells ovate, globose, straight to curved, entire, 7-9x5-7 $\mu \mathrm{m}$, phialides mixed with appressoria, opposite, ampulliform, 14-16x4-7 $\mu \mathrm{m}$. Mycelial setae many, scattered, simple, straight, acute to obtuse at the tip, up to $350 \mu \mathrm{m}$. Perithecia scattered, up to $132 \mu \mathrm{m}$ in diam. Ascospores oblong, cylindrical, 4-septate, slightly constricted at the septa, 31-44×12-16 $\mu \mathrm{m}$.

Material examined: 22.iii.2007, Kerala, Thiruvananthapuram, Palode, JNTBGRI Campus, on leaves of Bauhinia purpurea L. (Caesalpiniaceae) 22.iii.2007, A. Sabeena \& Jacob Thomas HClO 48057 (holotype), TBGT 2840 (isotype); 15.xi.2007, A. Sabeena et al. HClO 48374, TBGT 3095.

Based on the Beeli formula (3113. 4222) and host specificity, this fungus is similar to Meliola bauhinicola Yamam (Hansford 1961). However, var. brevipoda differs from the var. bauhinicola in having shorter appressoria (9-14 $\mu \mathrm{m}$ against 14-24 $\mu \mathrm{m}$ ).

Meliola caesalpiniicola Deight., Sydowia 11:40, 1958; Hansf., Sydowia Beih. 2: 253, 1961. (Fig. 45).

Colonies amphigenous, subdense to dense, up to $4 \mathrm{~mm}$ in diameter, confluent. Hyphae straight to substraight, branching opposite at acute to wide angles, loosely reticulate, cells $13-23 \times 6-8 \mu \mathrm{m}$. Appressoria opposite, unilateral, $2 \%$ alternate, antrorse to subantrorse, 16-18

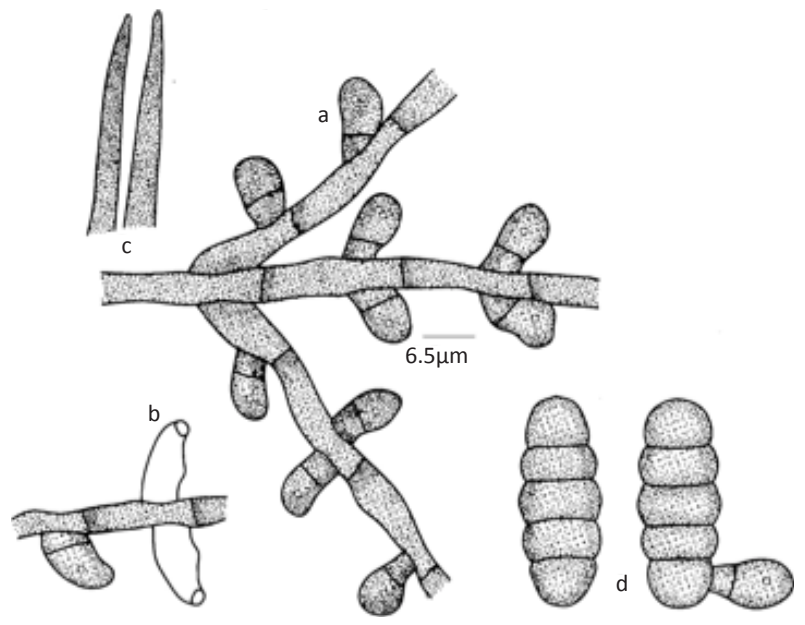

Figure 44. Meliola bauhiniicola var. brevipoda a - Appressorium; b - Phialide; c - Apical portion of mycelial setae; d - Ascospores

$\mu \mathrm{m}$ long; stalk cells cylindrical to cuneate, $3-5 \mu \mathrm{m}$ long; head cells ovate, globose, oblong, entire, 11-13x7$10 \mu \mathrm{m}$. Phialides mixed with appressoria, opposite, ampulliform, 16-27x3-6 $\mu \mathrm{m}$. Mycelial setae numerous, simple, straight to uncinate, acute at the tip, up to $294 \mu \mathrm{m}$ long. Perithecia numerous, scattered, up to $182 \mu \mathrm{m}$ in diameter; ascospores cylindrical to obovoidal, 4-septate, constricted at the septa, 38-52x14-16 $\mu \mathrm{m}$.

Materials examined: 21.i.2011, Kerala, Kannur, Payyannur, Edat, on leaves of Caesalpinia banduc (L.) Roxb. (Caesalpiniaceae), P. Ramya TBGT 4933, HCIO 51016.

This species was known on Caesalpinia nuga from Philippines and is reported here for the first time from India on a hitherto unrecorded host (Hansford 1961).

Meliola calycopteridis sp. nov. Hosag., G.R. Archana, K.M. Khaleel \& M.P. Libina.

(Fig. 46; MycoBank 803911)

Colonies epiphyllous, thin, up to $2 \mathrm{~mm}$ in diameter, scattered. Hyphae substraight to flexuous, branching opposite at acute angles, loosely to closely reticulate, cells $16-27 \times 4-8 \mu \mathrm{m}$. Appressoria alternate, unilateral, antrorse, $13-20 \mu \mathrm{m}$ long; stalk cells cylindrical to cuneate, 3-7 $\mu \mathrm{m}$ long; head cells globose, ovate, entire to slightly angular, 9-13x9-12 $\mu \mathrm{m}$. Phialides mixed with appressoria, opposite, ampulliform, 13-37x8-10 $\mu \mathrm{m}$. Mycelial setae numerous, simple, straight to uncinate, acute to obtuse at the tip, up to $588 \mu \mathrm{m}$ long. Perithecia scattered to grouped, up to $146 \mu \mathrm{m}$ in diameter; ascospores cylindrical to obovoidal, 4-septate, constricted at the septa, 26-33×13-17 $\mu \mathrm{m}$. 


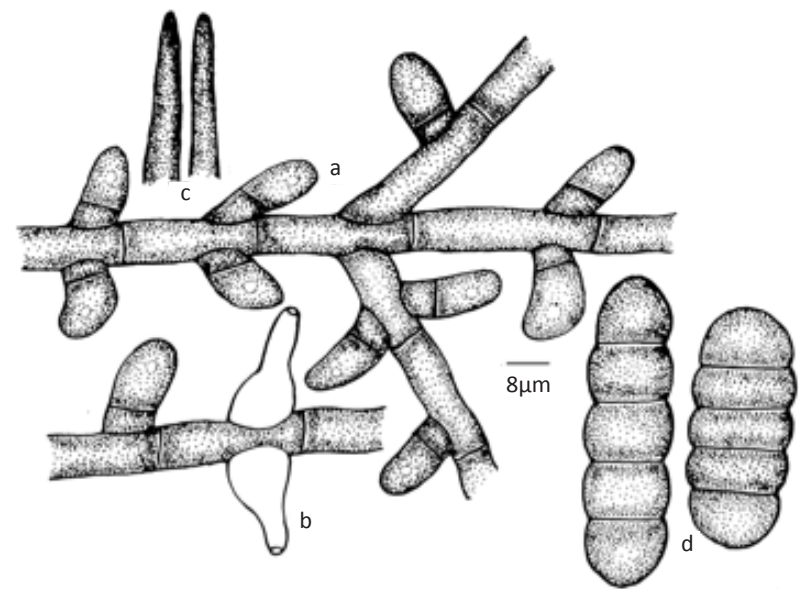

Figure 45. Meliola caesalpiniicola

a - Appressorium; b - Phialide; c - Apical portion of mycelial setae; d - Ascospores

Materials examined: TBGT 4906 ((holotype), HCIO 50989 (isotype), 21.i.2011, Kerala, Kannur, Mangattuparamba, Neeliyarkottam, on leaves of Calycopteris floribunda (Roxb.) Poiret (Combretaceae), M.P. Libina.

Asteridiella combreti (Stev.) Hansf. var. leonensis Hansf. is known on this host plant but differs from it in having mycelial setae (Hosagoudar 1996). Based on the digital formula, it is close to Meliola sudanensis Hansf. but differs from it in having longer mycelial setae and shorter but broader ascospores (Hansford 1961).

Meliola canavaliae Hosag. \& Riju, Plant Pathology \& Quarantine 1(2): 125, 2011. (Fig. 47).

Colonies foliicolous, epiphyllous, thin, scattered, up to $4 \mathrm{~mm}$ in diam. Hyphae flexuous to undulate, branching mostly opposite at acute to wide angles, loosely to closely reticulate, cells $15-38 \times 5-8 \mu \mathrm{m}$. Appressoria alternate, unilateral, rarely opposite, straight to slightly curved, antrorse, subantrorse to retrorse, 10-18 $\mu \mathrm{m}$ long; stalk cells cylindrical to cuneate, $2-8 \mu \mathrm{m}$ long; head cells ovate, globose, $10-15 \times 8-15 \mu \mathrm{m}$. Phialides mixed with appressoria, opposite, unilateral, ampulliform, 15-25 $\times 7-10 \mu \mathrm{m}$. Mycelial setae scattered to grouped around perithecia, simple, straight to slightly curved, acute to obtuse at the tip, up to $340 \mu \mathrm{m}$ long. Perithecia scattered, up to $160 \mu \mathrm{m}$ in diam.; ascospores cylindrical, 4-septate, slightly constricted at the septa, 33-35×10$13 \mu \mathrm{m}$.

Material examined: TBGT 4960 (holotype), HClO 51043 (isotype), 10.1.2011, Kerala, Wayanad, Padinharathara, 16th mile, on leaves of Canavalia sp. (Fabaceae), M.C. Riju.

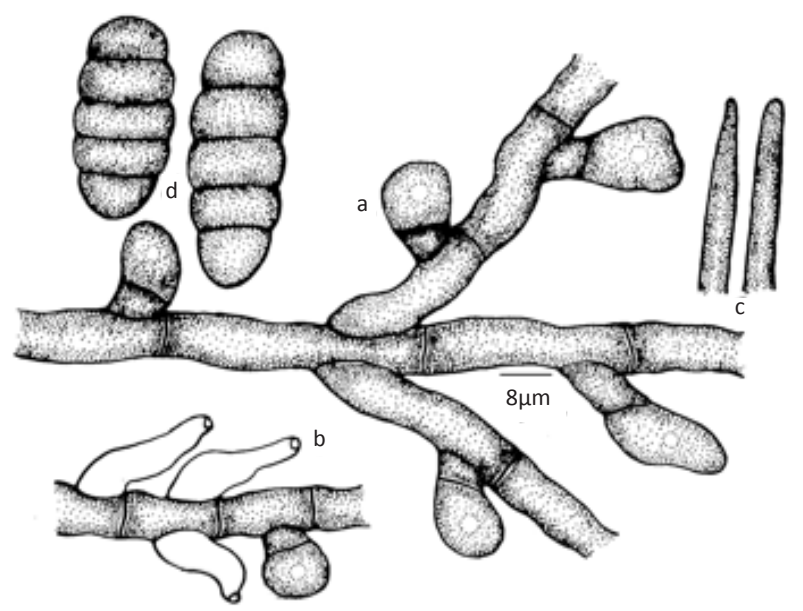

Figure 46. Meliola calycopteridis sp. nov.

a - Appressorium; b - Phialide; c - Apical portion of mycelial setae; d-Ascospores

Hansford (1961) identified M. teramni Sydow infecting leaves of Canavalia ensiformis collected by F.C. Deighton from Sierra Leone. The present fungus is similar but differs in having shorter (340 $\mu \mathrm{m}$ vs. 1000 $\mu \mathrm{m}$ ), acute to obtuse setae (in contrast to 2-4 dentate or furcate) and smaller ascospores (33-35×10-13 $\mu \mathrm{m}$ vs. 35-42×13-16 $\mu \mathrm{m})$.

Meliola canthiigena Hosag., Archana. \& Agarwal, Indian Phytopath. 60: 239, 2007. (Fig. 48).

Colonies amphigenous, thin, up to $2 \mathrm{~mm}$ in diameter, confluent. Hyphae straight to substraight, branching opposite to alternate at acute to wide angles, loosely to closely reticulate, cells $11-29 \times 6-8 \mu \mathrm{m}$. Appressoria alternate to unilateral, antrorse to subantrorse, straight to curved, $12-27 \mu \mathrm{m}$ long; stalk cells cylindrical to cuneate, 3-11 $\mu \mathrm{m}$ long; head cells ovate, oblong, entire to slightly angular, 9-18x6-11 $\mu \mathrm{m}$. Phialides mixed with appressoria, alternate to opposite, ampulliform, 11-27x6-10 $\mu \mathrm{m}$. Mycelial setae simple, straight, acute at the tip, up to $600 \mu \mathrm{m}$ long. Perithecia grouped, globose, up to $160 \mu \mathrm{m}$ in diameter; ascospores obvoidal, 4-septate, constricted at the septa, 32-35x12-16 $\mu \mathrm{m}$.

Material examined: HClO (holotype), TBGT 2357 (isotype), 11.xi.2003, Karnataka, Coorg, Nishanemotta, Madikeri, on leaves of Canthium sp. (Rubiaceae), V.B. Hosagoudar et al.

Based on the host specificity, Meliola canthiigena can be compared with M. canthii Hansf. known on Canthium vulgare from Uganda (Hansford 1961) but differs from it in having entire head cells of the appressoria, longer mycelial setae and smaller ascospores (Hansford 1961). 


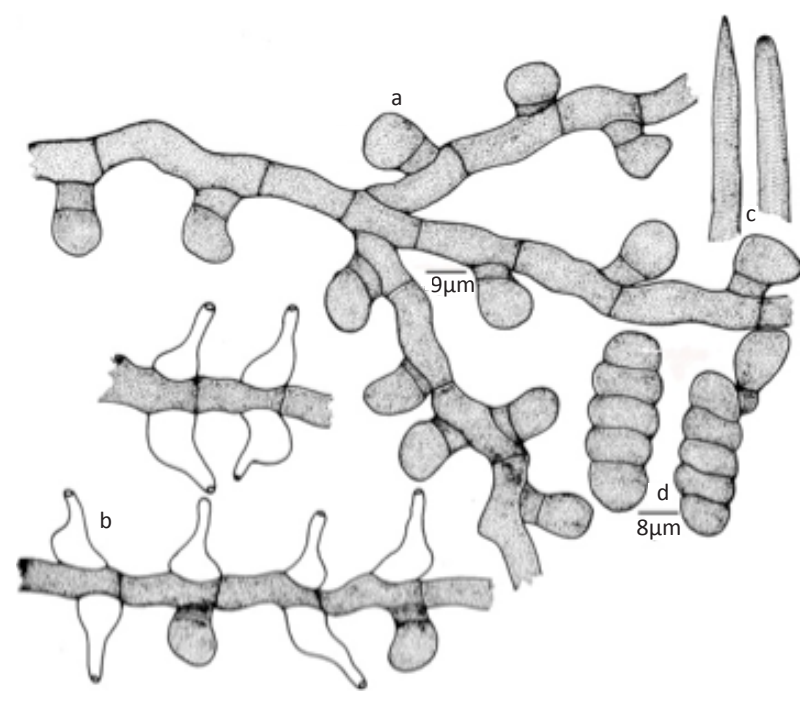

Figure 47. Meliola canavaliae

a - Appressorium; b - Phialide; c - Apical portion of mycelial setae; d - Ascospores

Meliola cariappae sp. nov. V.B. Hosagoudar, Jagath Thimmaiah \& G.R. Archana.

(Fig. 49; MycoBank 803913)

Colonies epiphyllous, dense, up to $4 \mathrm{~mm}$ in diam., confluent. Hyphae substraight to flexuous to slightly crooked, branching mostly opposite, loosely to closely reticulate, cells $14-20 \times 6-8 \mu \mathrm{m}$. Appressoria alternate, opposite to unilateral, antrorse to subantrorse, straight to variously curved, 19-27 $\mu \mathrm{m}$ long; stalk cells cylindrical to cuneate, often gibbous, 4-11 $\mu \mathrm{m}$ long; head cells ovate, oblong to cylindrical, entire, angular, crenately lobate to sublobate, 12-27x11-15 $\mu \mathrm{m}$. Phialides mixed with appressoria, alternate to opposite, ampulliform, 17-27x4-8 $\mu \mathrm{m}$. Mycelial setae grouped around perithecia, simple, straight, acute at the tip, up to $475 \mu \mathrm{m}$ long. Perithecia loosely grouped, up to $177 \mu \mathrm{m}$ in diam.; ascospores oblong to cylindrical, 4-septate, constricted at the septa, 40-46×14-17 $\mu \mathrm{m}$.

Materials examined:TBGT 5824 (holotype), 14.i.2010, On leaves of Michelia champaka L. (Magnoliaceae), Sampaje Ghats, Kodagu, Karnataka, C. Jagat Thimmaiah.

Etymology: Named in honour of the India's first Air Marshal K.C. Cariappa.

Asteridiella micheliae Jana et al. (Hosagoudar 2008) known on this host genus from northeastern India but differs from it in absence of mycelial setae. It also differs from Meliola micheliae Hansf. known on Michelia fuscata from Sri Lanka in having mostly angular to sublobate head cells of appressoria (Hansford 1961).

Meliola cayratiae Hosag., Jacob Thomas \& Agarwal, Nelumbo 52: 3, 2010. (Fig. 50).

Colonies epiphyllous, dense, velvety, scattered, up to $2 \mathrm{~mm}$ in diameter. Hyphae straight to undulate, branching opposite at acute to wide angles, closely reticulate to form a mycelial mat, cells $12-22 \times 7-12 \mu \mathrm{m}$. Appressoria opposite, about $20 \%$ alternate to unilateral, very closely placed, mostly antrorse, rarely spreading, straight to slightly curved, 16-22 $\mu \mathrm{m}$ long; stalk cells cylindrical to cuneate, 2-5 $\mu \mathrm{m}$ long; head cells ovate to oblong, cylindrical, entire, slightly angular, often truncate at the apex, 14-19x9-15 $\mu \mathrm{m}$. Phialides mixed with

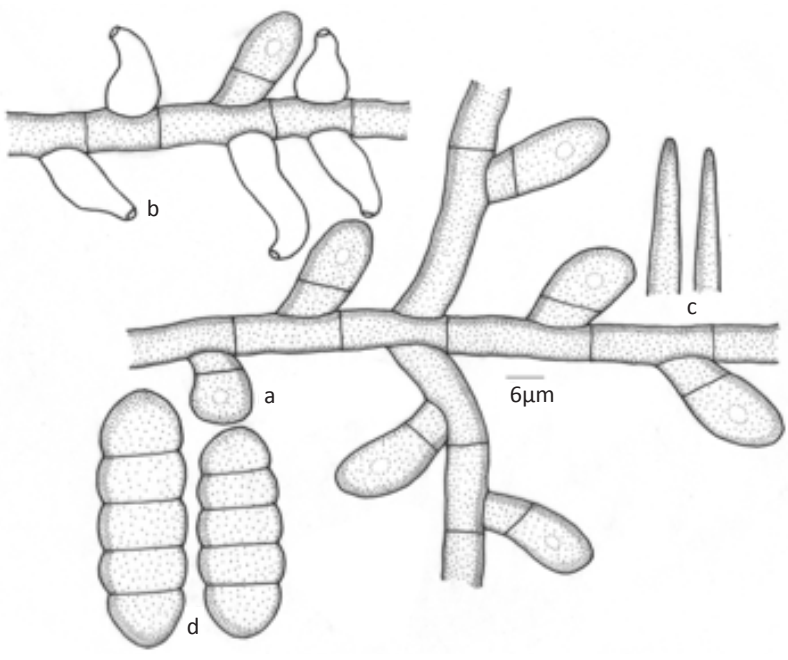

Figure 48. Meliola canthiigena

a - Appressorium; b - Phialide; c - Apical portion of mycelial setae; d - Ascospores

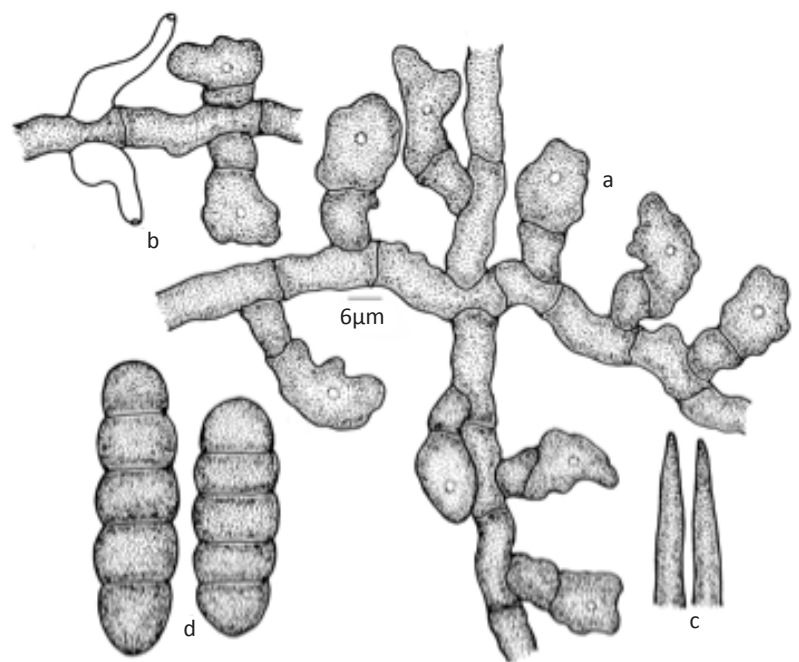

Figure 49. Meliola cariappae sp. nov.

a - Appressorium; b - Phialide; c - Apical portion of mycelial setae; d - Ascospores 
appressoria, alternate to opposite, ampulliform, 1622x7-10 $\mu \mathrm{m}$. Mycelial setae grouped around perithecia, straight, simple, obtuse to broadly rounded at the tip, up to $520 \mu \mathrm{m}$ long. Perithecia scattered, verrucose, up to $240 \mu \mathrm{m}$ in diam.; ascospores cylindrical to subellipsoidal, 4-septate, constricted at the septa, 38-43×14-17 $\mu \mathrm{m}$.

Materials examined: HClO 48840 (holotype), TBGT 3216 (isotype), TBGT 3217, 1.iii.2008, Kerala, Thiruvananthapuram, Neyyar Wildlife Sanctuary, Pongalappara, on leaves of Cayratia pedata (Lam.) A.L.Juss.ex Gagnepain (Vitaceae), Jacob Thomas.

Based on the digital formula 3113.4233, it is similar to Meliola bakeri Sydow (Hansford 1961; Hosagoudar 1996; Hosagoudar \& Agarwal, 2008) but differs from it in having mycelial setae grouped around perithecia with broadly obtuse tip. Often sterile mycelia emerged from the base of the perithecia.

Meliola cipadessae Hosag., Jacob Thomas \& Agarwal, Nelumbo 52: 5, 2010. (Fig. 51).

Colonies epiphyllous, thin, velvety, up to $2 \mathrm{~mm}$ in diameter, confluent, mixed with the colonies of Aserina cipadessae. Hyphae straight to substraight, branching opposite at acute to angles, closely reticulate, cells 16-26x6-8 $\mu \mathrm{m}$. Appressoria alternate, straight to curved, antrorse to spreading, 16-21 $\mu \mathrm{m}$ long; stalk cells cylindrical to cuneate, 4-8 $\mu \mathrm{m}$ long; head cells straight to curved, ovate, globose, cylindrical, entire, 11-16x6$10 \mu \mathrm{m}$. Phialides mixed with appressoria, alternate to opposite, ampulliform, 12-19x6-8 $\mu \mathrm{m}$. Mycelial setae scattered to grouped around perithecia, simple, straight, acute to obtuse at the tip, up to $550 \mu \mathrm{m}$ long. Perithecia grouped, verrucose, up to $210 \mu \mathrm{m}$ in diameter; ascospores

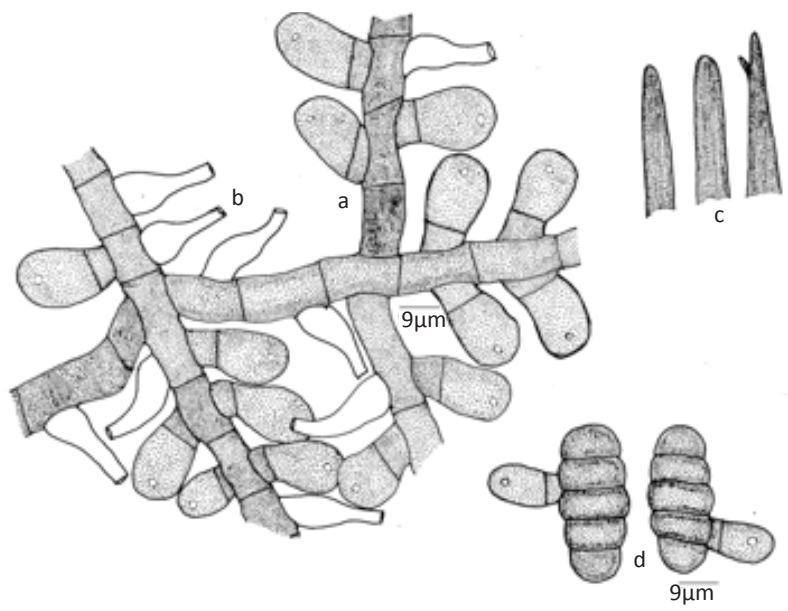

Figure 50. Meliola cayratiae

a - Appressorium; b - Phialide; c - Apical portion of mycelial setae; d - Ascospores obovoidal to cylindrical, 4-septate, constricted at the septa, 32-35x12-15 $\mu \mathrm{m}$.

Materials examined: HCIO 48871 (holotype), TBGT 3247 (isotype), 6.iii.2008, Kerala, Thiruvananthapuram, Peppara Wildlife Sanctuary, Bonocaud, on leaves of Cipadessa bacciferra (Roth) Miq. (Meliaceae), Jacob Thomas.

Based on the digital formula 3111.3233, it can be compared with Meliola togoensis Hughes var. angulata Hughes known on Trichilia prieuriana from Gold Coast. However, differs from it in having shorter appressoria with entire head cells. Further, this is the first report of the genus Meliola on this host genus Cipadessa (Hansford 1961; Hosagoudar 1996; Hosagoudar \& Agarwal 2008).

Meliola clausenigena Hosag. \& Riju, J. Threatened Taxa 3(3): 1617, 2011. (Fig. 52).

Colonies amphigenous, dense, velvety, up to $3 \mathrm{~mm}$ in diam., scattered to confluent. Hyphae straight, flexuous, branching opposite at wide angles, loosely to closely reticulate, cells $15-30 \times 5-8 \mu \mathrm{m}$. Appressoria mostly opposite, rarely unilateral, antrorse to subantrorse, 17-23 $\mu \mathrm{m}$ long; stalk cells cylindrical to cuneate, $5-8 \mu \mathrm{m}$ long; head cells ovate, oblong, rarely globose, straight to curved, entire, often sinuate, truncate at the apex, 12-15x7-10 $\mu \mathrm{m}$. Phialides mixed with appressoria, opposite, alternate to unilateral, 15-20x7-10 $\mu \mathrm{m}$. Mycelial setae simple, straight to uncinate at the apical portion, acute, obtuse to 2-3 times dentate at the tip, up to $240 \mu \mathrm{m}$ long. Perithecia scattered to grouped in the colonies, up to $190 \mu \mathrm{m}$ in diam.; ascospores oblong

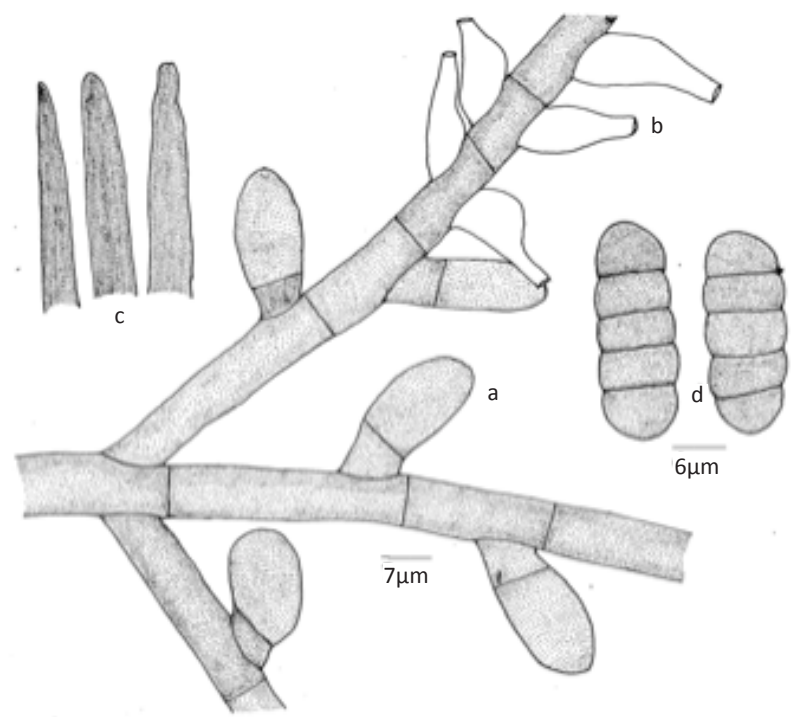

Figure 51. Meliola cipadessae

a - Appressorium; b - Phialide; c - Apical portion of mycelial setae; d - Ascospores 


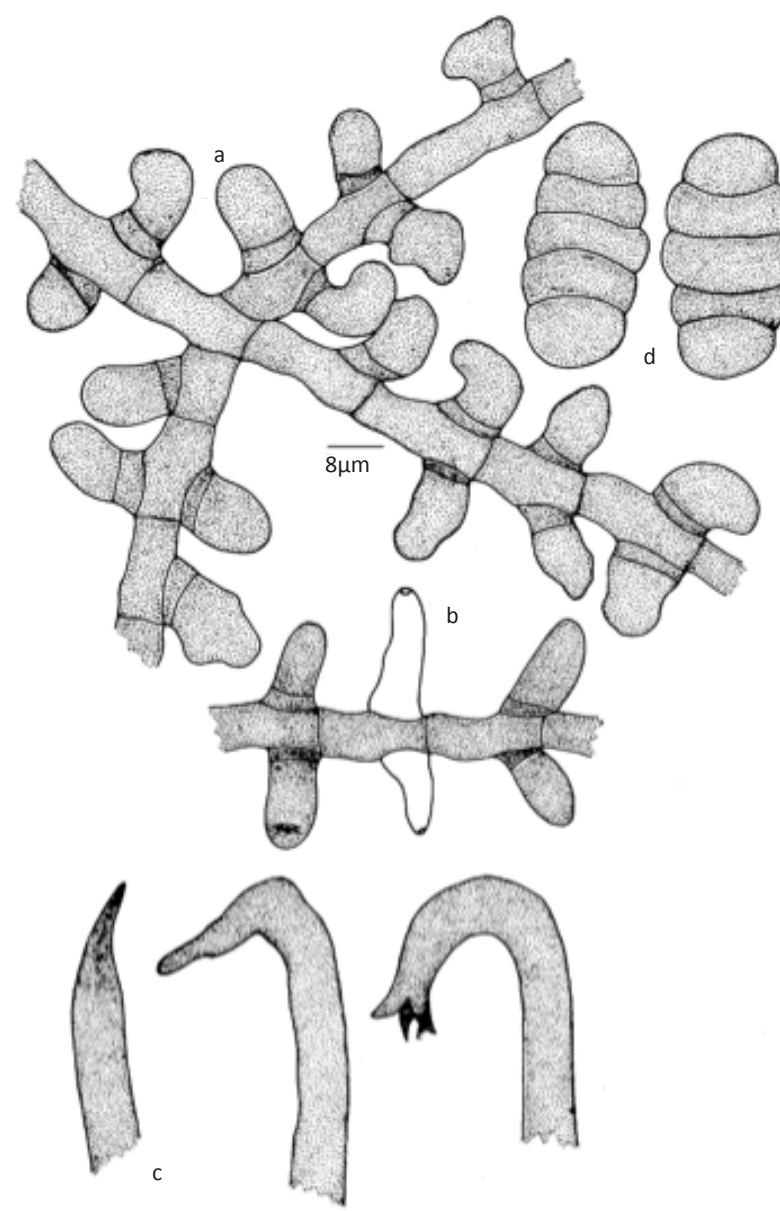

Figure 52. Meliola clausenigena

a - Appressorium; b - Phialide; c - Apical portion of mycelial setae; $\mathrm{d}$ - Ascospores

to cylindrical, 4-septate, constricted at the septum, 3740x15-20 $\mu \mathrm{m}$.

Material examined: TBGT 4514 (holotype), HClO 50597 (isotype), 1.viii.2008, Kerala, Palakkad, Silent Valley National Park, Poochipara, on leaves of Clausena sp. (Rutaceae), M.C. Riju et al.

This is the only species of the genus Meliola known on the members of the family Rutaceae having straight, curved to uncinate apical portion of the mycelial setae (Hansford 1961; Hosagoudar et al. 1996; Hu et al. 1996, 1999; Hosagoudar 1996, 2008; Hosagoudar \& Agarwal 2008). The specific epithet is derived from the host genus.

Meliola colubrinicola Hosag. \& Sabeena, Plant Pathology \& Quarantine 3(1): 11, 2012. (Fig. 53).

Colonies hypophyllous, subdense to dense, up to $3 \mathrm{~mm}$ in diameter, confluent. Hyphae flexuous to crooked, branching opposite to irregular at acute to wide angles, loosely to closely reticulate, cells $25-40 \times 5-7 \mu \mathrm{m}$.
Appressoria alternate, antrorse, subantrorse to retrorse, 15-20 $\mu \mathrm{m}$ long; stalk cells cylindrical to cuneate, 2-7 $\mu \mathrm{m}$ long; head cells oblong, ovate, entire, 10-15×10-15 $\mu \mathrm{m}$. Phialides mixed with appressoria, opposite, ampulliform, 12-25x5-7 $\mu \mathrm{m}$. Mycelial setae scattered, simple, straight, up to $850 \mu \mathrm{m}$ long, acute to obtuse at the tip. Perithecia scattered, orbicular, up to $200 \mu \mathrm{m}$ in diam.; ascospores ellipsoidal to oblong, 4-septate, constricted at the septa, 37-42x12-15 $\mu \mathrm{m}$.

Materials examined: TBGT 5733 (holotype), 25.xi.2009, India, Kerala, Kottayam, Ponthanpuzha, on leaves of Colubrina travancorica Bedd. (Rhamnaceae), P.J. Robin et al. Part of the collection has been deposited in $\mathrm{HClO}$, New Delhi.

Asteridiella colubrinae (Stev.) Hansf. known on Colubrina ruffa from Panama but the present species differs from it in having mycelial setae (Hansford 1961).

Meliola cookeana Speg., Ann. Soc. Cient. Argentina 12: 41, 1881; Hansf., Sydowia Beih. 2: 695, 1961; Hosag. \& Sabeena, Bulletin of Basic and Applied Plant Biology, 1(1): 49, 2011. Meliola rizalensis Sydow , Ann. Mycol. 12: 551, 1914. (Fig. 54).

Colonies epiphyllous, subdense to dense, up to $4 \mathrm{~mm}$ in diameter, confluent. Hyphae substraight, branching opposite to unilateral at acute to wide angles, loosely to closely reticulate, cells $27-42 \times 5-7 \mu \mathrm{m}$. Appressoria alternate to unilateral, antrorse to subantrorse, 15-20 $\mu \mathrm{m}$ long; stalk cells cylindrical to cuneate, $5-7 \mu \mathrm{m}$ long;

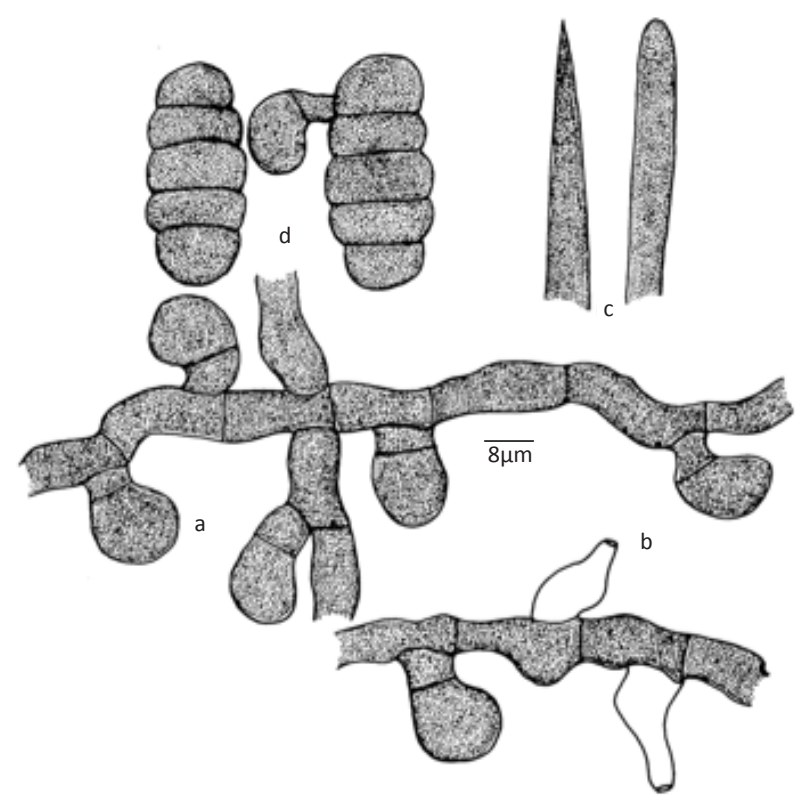

Figure 53. Meliola colubrinicola

a - Appressorium; b - Phialide; c - Apical portion of mycelial setae; d - Ascospores 
head cells globose to ovate, entire, 10-12x7-12 $\mu \mathrm{m}$. Phialides mixed with appressoria, opposite to unilateral, ampulliform, 12-17x5-7 $\mu \mathrm{m}$. Mycelial setae straight to curved, simple, up to $300 \mu \mathrm{m}$ long, acute to obtuse at the tip. Perithecia scattered, up to $150 \mu \mathrm{m}$ in diam. Ascospores oblong to cylindrical, 4-septate, constricted at the septa, 30-37x10-15 $\mu \mathrm{m}$.

Material examined: TBGT 5098, 25.iii.2009, Kerala, Kottayam, Koruthodu, on leaves of Vitex leucoxylon L.f. (Verbenaceae), V. Gireesh Kumar et al. Part of the collection has been deposited in $\mathrm{HClO}$, New Delhi.

L.J. Sedgwick had collected this species on this host plant from North Canara, Karnataka, during the month of October, 1919. Since then there was no collection of this species on this host and the present collection forms the relocation of this species after a lapse of more than nine decades (Hansford 1961; Hosagoudar 1996).

Meliola cynanchi Hosag., H. Biju, Agarwal \& Archana, Indian Phytopath. 59: 345, 2006. (Fig. 55).

Colonies epiphyllous, thin to dense, up to $2 \mathrm{~mm}$ in diam. Hyphae straight, substraight to flexuous, branching alternate to opposite at acute to wide angles, loosely to closely reticulate, cells $16-27 \times 6-8 \mu \mathrm{m}$. Appressoria alternate, about $20 \%$ opposite, antrorse to subantrorse, 16-20 $\mu \mathrm{m}$ long; stalk cells cylindrical to cuneate, 4-6 $\mu \mathrm{m}$

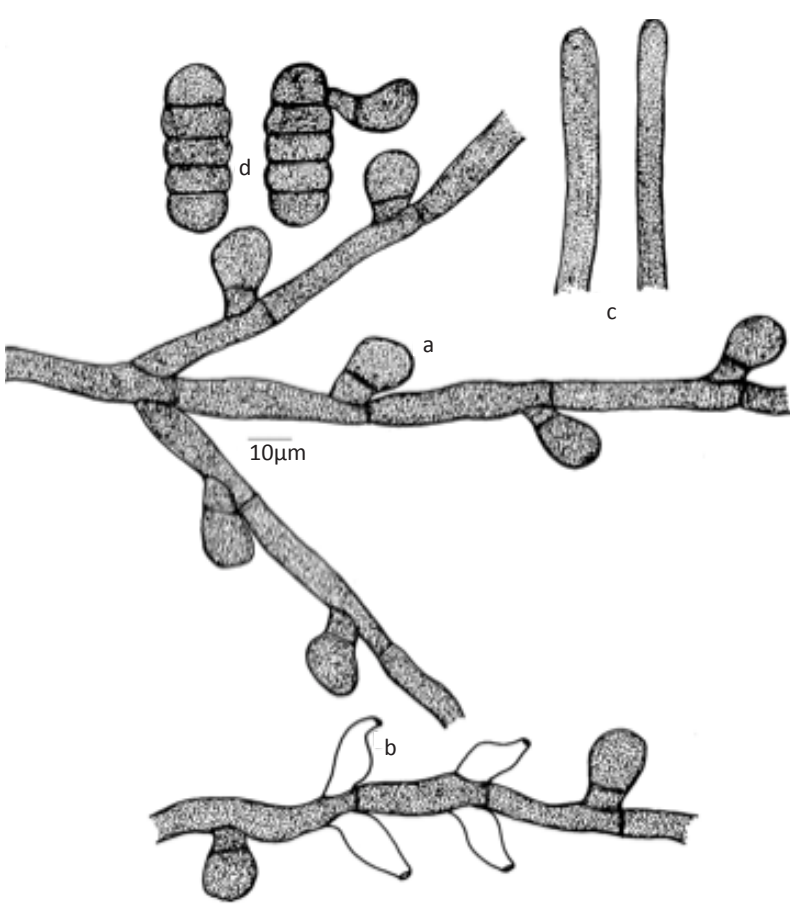

Figure 54. Meliola cookeana

a - Appressorium; b - Phialide; c - Apical portion of mycelial setae; d - Ascospores long; head cells globose to ovate, entire, 9-13x9-11 $\mu \mathrm{m}$. Phialides mixed with appressoria, alternate to opposite, ampulliform, 16-25x8-10 $\mu \mathrm{m}$. Mycelial setae many, densely scattered, simple, straight to curved, very few uncinate, obtuse, dentate, cristate, often furcate up to $20 \mu \mathrm{m}$ at the tip, up to $600 \mu \mathrm{m}$ long. Perithecia scattered, up to $125 \mu \mathrm{m}$ in diam.; ascospores oblong, cylindrical to slightly ellipsoidal, 4-septate, constricted at the septa, 38-42×15-17 $\mu \mathrm{m}$.

Material examined: HCIO 46245 (holotype), TBGT 1657 (isotype), 12.xi.2003, Karnataka, Coorg, Madikeri, Jodupal, on leaves of Cynanchum sp. (Asclepiadaceae), V.B. Hosagoudar et al.

Meliola asclepiadacearum Hansf. is known on the host genus Cynanchum. According to Beeli formula $31 \frac{1}{3} 3.4223$, it is similar to $M$. hoyae Sacc.. M. cynanchi differs from the former species in having opposite appressoria and dentate to furcate and longer mycelial setae. While, it differs from the latter species in having longer and dentate to furcate mycelial setae (Hansford 1961; Hosagoudar et al. 1997).

Meliola cyperacearum Hosag., Dhivaharan \& Riju, J. Sci. Trans. Technov. 4(4): 165, 2011. (Fig. 56).

Colonies amphigenous, dense, velvety, up to $2 \mathrm{~mm}$ in diameter, confluent. Hyphae straight to substraight, branching alternate at acute angles, cells 20-23x7-9 $\mu \mathrm{m}$. Appressoria alternate, straight to curved, 30-35 $\mu \mathrm{m}$ long; stalk cells cylindrical to cuneate, 10-12 $\mu \mathrm{m}$ long; head cells cylindrical, globose, slightly angular, sublobate to lobate, often truncate at the apex, 20-22x10-17 $\mu \mathrm{m}$. Phialides borne on a separate mycelial branch, alternate, ampulliform, 15-20x7-9 $\mu \mathrm{m}$. Mycelial setae straight, simple, acute to obtuse at the tip, up to 360 $\mu \mathrm{m}$ long. Perithecia scattered, up to $140 \mu \mathrm{m}$ in diameter; ascospores obovoidal, 4-septate, constricted at the
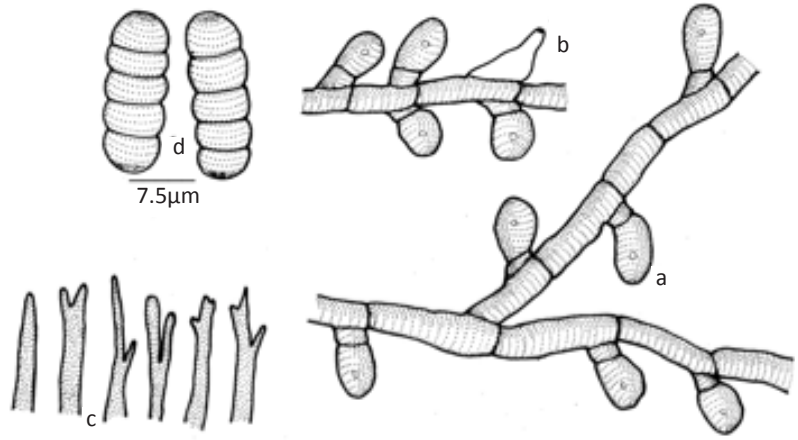

Figure 55. Meliola cynanchi

a - Appressorium; b - Phialide; c - Apical portion of mycelial setae; d - Ascospores 
septa, 35-37x12-15 $\mu \mathrm{m}$.

Materials examined: TBGT 4391 (holotype). HCIO 50474 (isotype), 7.i.2007, Tamil Nadu, Kodaikanal, Kukkal shola forest, Periyakanal, on leaves of Cyperus sp. (Cyperaceae), V. Dhivaharan et al.

Based on the angular to sublobate head cells of appressoria and the position of the Phialides on a separate mycelial branch, this species can be compared with Meliola cyperi Pat. but differs from it in having distinctly shorter mycelial setae (Hansford 1961). It also differs from Meliola tibigirica Hosag. et al. in having distinctly lobate head cells of appressoria (Hosagoudar 2008).

Meliola daviesii Hansf. var. kodaikanalensis Hosag., Dhivaharan \& Riju, J. Sci. Trans. TechNovember 4(4): 166, 2011.

Colonies epiphyllous, thin, up to $2 \mathrm{~mm}$ in diameter scattered. Hyphae flexuous, branching opposite at wide angles, loosely reticulate, cells 20-30x7-10 $\mu \mathrm{m}$. Appressoria alternate, straight to curved, antrorse to retrorse, 30-32 $\mu \mathrm{m}$ long; stalk cells cylindrical to cuneate, 7-10 $\mu \mathrm{m}$ long; head cells oblong, ovate, rarely globose, entire, 20-25x12-17 $\mu \mathrm{m}$. Phialides mixed with appressoria, opposite, ampulliform, 20-22x7-10 $\mu \mathrm{m}$. Mycelial setae scattered, simple, obtuse at the tip, up to $440 \mu \mathrm{m}$ long. Perithecia scattered, globose upto $85 \mu \mathrm{m}$ in diameter; ascospores oblong, 4-septate, constricted at the septa, $45-47 \times 15-20 \mu \mathrm{m}$.

Materials examined: 7.iii.2007, Tamil Nadu, Kodaikanal, Kukkal shola forest, Periyakanal, on leaves of Jasminum brevilobum A. DC. (Oleaceae), V. Dhivaharan et al. TBGT 4445 (holotype), HClO 50528 (isotype); 7.ii.2007, Kodaikanal, Periya kanal, R. Nithya tharani HCIO 50648, TBGT 4565.

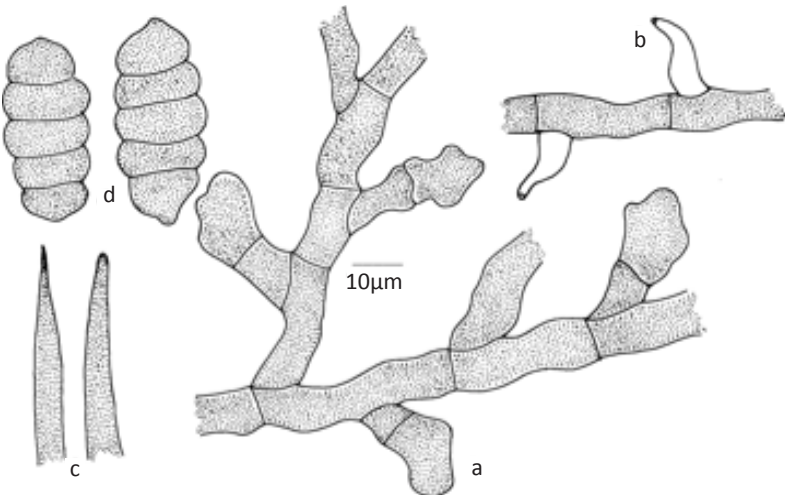

Figure 56. Meliola cyperacearum

a - Appressorium; b - Phialide; c - Apical portion of mycelial setae; d - Ascospores
Based on the digital formula, nature of the hyphae and morphology of appressoria, the present collection fits well into the assigned species but the new variety differs from it in having phialides borne with appressoria.

Meliola desmodii-laxiflori Deight. var. indica Hosag., Agarwal, Biju \& Archana, Indian Phytopath. 59: 346, 2006. (Fig. 58).

Colonies epiphyllous, dense, up to $2 \mathrm{~mm}$ in diam. Hyphae flexuous to crooked, branching alternate to opposite at acute to wide angles, loosely to closely reticulate, cells $24-30 \times 5-7 \mu \mathrm{m}$. Appressoria alternate, antrorse to subantrorse, 12-21 $\mu \mathrm{m}$ long; stalk cells cylindrical to cuneate, 2-7 $\mu \mathrm{m}$ long; head cells ovate, globose, straight to curved, entire, rarely slightly angular, 11-15x11-13 $\mu \mathrm{m}$. Phialides borne on a separate mycelial branch, alternate to opposite, ampulliform, 12-18x7-9 $\mu \mathrm{m}$. Mycelial setae scattered, simple, straight, acute to obtuse at the tip, up to $430 \mu \mathrm{m}$ long. Perithecia scattered, up to $130 \mu \mathrm{m}$ in diam.; ascospores oblong to cylindrical, slightly constricted at the septa, 32-35x9-11 $\mu \mathrm{m}$.

Material examined: HClO 46236 (holotype), TBGT 1648 (isotype); HClO 46242, TBGT 1654, 12.xi.2003, Karnataka, Coorg, Madikeri, Jodupal, on leaves of Desmodium laxiflorum DC. (Fabaceae), V.B. Hosagoudar et al.

Meliola dioscoreacearum Hosag. \& Jacob Thomas, Indian J. Sci. Technol. 2(6): 22, 2009. (Fig. 59).

Colonies epiphyllous, dense, velvety, up to $2 \mathrm{~mm}$ in diameter, confluent. Hyphae straight, branching opposite at acute angles, loosely to closely reticulate, cells $16-34 \times 4-7 \mu \mathrm{m}$. Appressoria alternate, about 3\% opposite, antrorse to subantrorse, straight to curved,

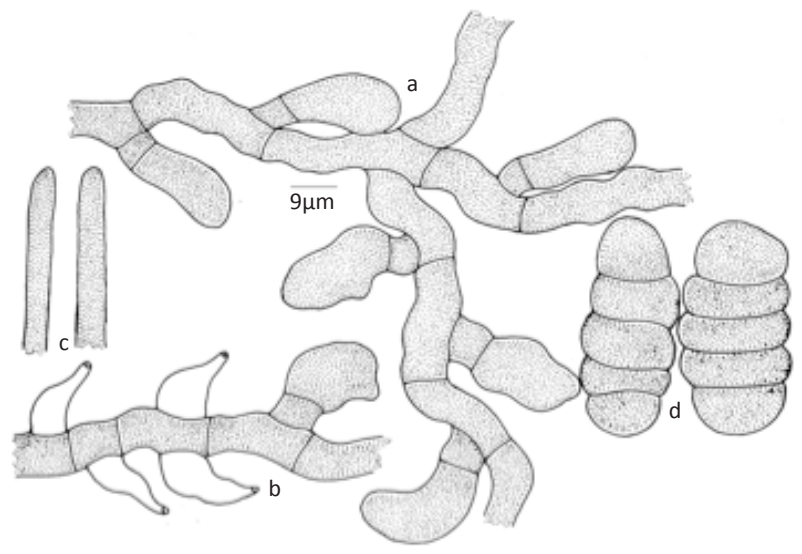

Figure 57. Meliola daviesii Hansf. var. kodaikanalensis

a - Appressorium; b - Phialide; c - Apical portion of mycelial setae; d - Ascospores 


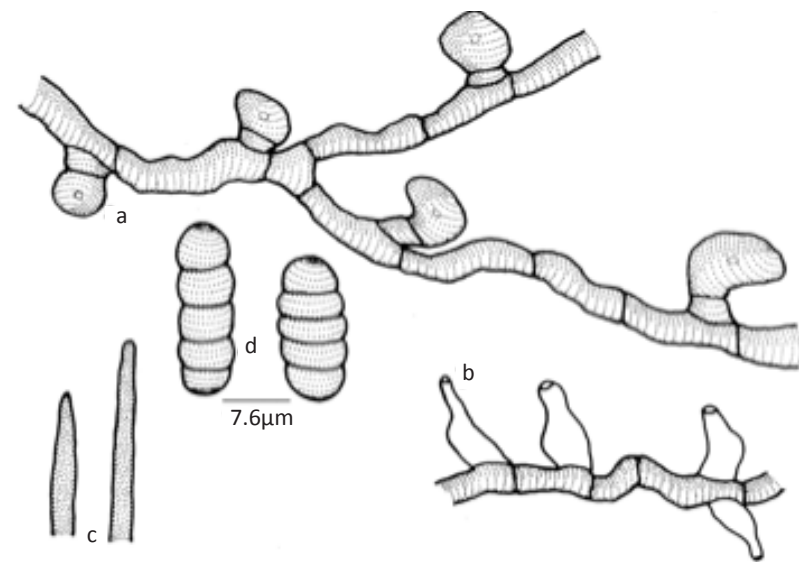

Figure 58. Meliola desmodii-laxiflori var. indica

a - Appressorium; b - Phialide; c - Apical portion of mycelial setae; d-Ascospores

14-19 $\mu \mathrm{m}$ long; stalk cells cylindrical to cuneate, 2-5 $\mu \mathrm{m}$ long; head cells curved, cylindrical, ovate, entire, rounded at the apex, 12-15x7-10 $\mu \mathrm{m}$. Phialides mixed with appressoria, alternate to opposite, ampulliform, 14-24x7-10 $\mu \mathrm{m}$. Mycelial setae scattered, straight, simple, acute to dentate at the tip, up to $510 \mu \mathrm{m}$ long. Perithecia scattered, verrucose, up to $200 \mu \mathrm{m}$ in diam.; ascospores cylindrical, 4-septate, strongly constricted at the septum, 36-38x14-17 $\mu \mathrm{m}$.

Materials examined: HClO 48251 (holotype), TBGT 2990 (isotype), 12.xi.2007, Kerala, Thrissur, Vazhachal, lower Sholayar, on leaves of Dioscorea sp. (Dioscoreaceae), Jacob Thomas et al.

Based on the dentate mycelial setae and oppositely placed appressoria, this species can be compared with Meliola dioscoreicola Hansf. \& Deight. and its variety peruviensis Hansf. but differs from both in having only $3 \%$ opposite appressoria, minutely dentate mycelial setae and the apical cells of the appressoria are typically ovate to cylindrical (Hansford 1961).

Meliola dioscoregena Hosag. \& Jacob., Indian J. Sci. Technol. 2(6): 22, 2009. (Fig. 60, Imgae. 8).

Colonies epiphyllous, dense, velvety, up to $2 \mathrm{~mm}$ in diameter, not confluent. Hyphae straight to substraight, branching opposite at acute angles, closely reticulate, cells 9-15x4-7 $\mu \mathrm{m}$. Appressoria opposite, less than $1 \%$ alternate, antrorse to spreading, straight to slightly curved, 12-17 $\mu \mathrm{m}$ long; stalk cells cylindrical to cuneate, 2-5 $\mu \mathrm{m}$ long; head cells subglobose to ovate, entire, 9-12x7-10 $\mu \mathrm{m}$. Phialides mixed with appressoria, alternate to opposite, ampulliform, 7-14x4-7 $\mu \mathrm{m}$. Mycelial setae scattered to grouped around perithecia, straight, simple, acute to obtuse at the tip, up to $440 \mu \mathrm{m}$

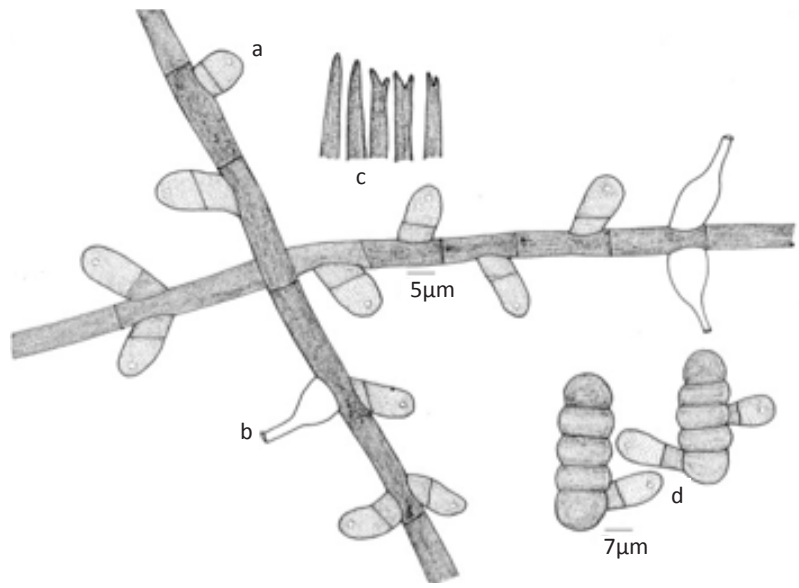

Figure 59. Meliola dioscoreacearum

a - Appressorium; b - Phialide; c - Apical portion of mycelial setae; d - Ascospores

long. Perithecia mostly grouped at the centre of the colony, verrucose, up to $190 \mu \mathrm{m}$ in diam.; ascospores cylindrical to ellipsoidal, 4-septate, constricted, 36$41 \times 14-17 \mu \mathrm{m}$.

Materials examined: HClO 48250 (holotype), TBGT 2989 (isotype), 18.xi.2007, Kerala, Thiruvananthapuram, Peppara Wildlife Sanctuary, on leaves of Dioscorea sp. (Dioscoreaceae), Jacob Thomas \& Vimalkumar.

Typically opposite appressoria distinguishes this species from rest of the Meliola species known on the members of the family Dioscoreaceae (Hansford 1961, Hosagoudar et al. 1997).

Ascospores produce three appressoria from the terminal cells and the mycelium is being produced from the sub-terminal cells.

Meliola diospyri-buxifoliae Hosag., Sabeena \& Riju, Bioscience Discovery 2: 120, 2011. (Fig. 61).

Colonies amphigenous, mostly epiphyllous, thin, up to $2 \mathrm{~mm}$ in diameter, confluent. Hyphae straight to substraight, branching opposite to unilateral at acute to wide angles, loosely reticulate, cells $13-24 \times 4-6$ $\mu \mathrm{m}$. Appressoria alternate, very rarely opposite, antrorse, subantrorse to retrorse, 11-15 $\mu \mathrm{m}$ long; stalk cells cylindrical to cuneate, 2-4 $\mu \mathrm{m}$ long; head cells ovate, globose, entire, 9-13x4-6 $\mu \mathrm{m}$. Phialides mixed with appressoria, opposite, alternate to unilateral, ampulliform, 13-22x4-9 $\mu \mathrm{m}$. Mycelial setae simple, straight, acute to obtuse at the tip, up to $450 \mu \mathrm{m}$ long. Perithecia scattered, up to $170 \mu \mathrm{m}$ in diam.; ascospores cylindrical, 4-septate, constricted at the septa, 2835x11-17 $\mu \mathrm{m}$.

Material examined: TBGT 3731 (holotype), HCIO 49489 (isotype), 15.xi.2007, Kerala, Thiruvananthapuram, 


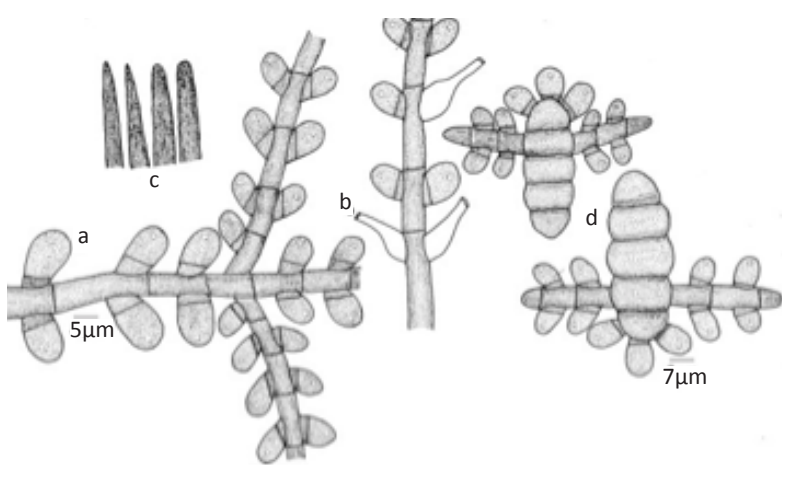

Figure 60. Meliola dioscoregena

a - Appressorium; b - Phialide; c - Apical portion of mycelial setae; d-Ascospores

Palode, JNTBGRI Campus, on leaves of Diospyros buxifolia (Blume) Hiern. (Ebenaceae), A. Sabeena \& M.C. Riju.

Meliola megalocarpa Sydow var. microspora Hosag., M. diospyri Sydow var. yatesiana Hansf. \& Deight. and $M$. diospyri Sydow are known on this host genus (Hansford
1961; Hosagoudar 1996). Based on the morphology of head cells of appressoria, this species is similar to $M$. diospyri known on Diospyros sp. from the Western Ghats. However, differs from it in having only $2 \%$ opposite (in contrast to $40 \%$ ) shorter appressoria (11-15 $\mu \mathrm{m}$ against 18-26 $\mu \mathrm{m})$ and having shorter ascospores (28-35 $\mu \mathrm{m}$ against $42-50 \mu \mathrm{m})$.

Meliola dysoxyligena Hosag. \& Riju, Plant Pathology \& Quarantine 1(2): 126, 2011. (Fig. 62).

Colonies epiphyllous, dense, velvety, up to $5 \mathrm{~mm}$ in diam. Hyphae substraight to crooked, branching opposite to irregular at acute to wide angles, loosely to closely reticulate, cells $20-45 \times 7-8 \mu \mathrm{m}$. Appressoria alternate, unilateral, opposite, antrorse, subantrorse to retrorse, 15-17×7-10 $\mu \mathrm{m}$; stalk cells cylindrical to cuneate, 3-5 $\mu \mathrm{m}$ long; head cells globose, subglobose, entire to rarely truncate, $10-13 \times 7-10 \mu \mathrm{m}$. Phialides mixed with appressoria, alternate to opposite, ampulliform, 15$38 \times 7-10 \mu \mathrm{m}$. Mycelial setae scattered, simple, straight,
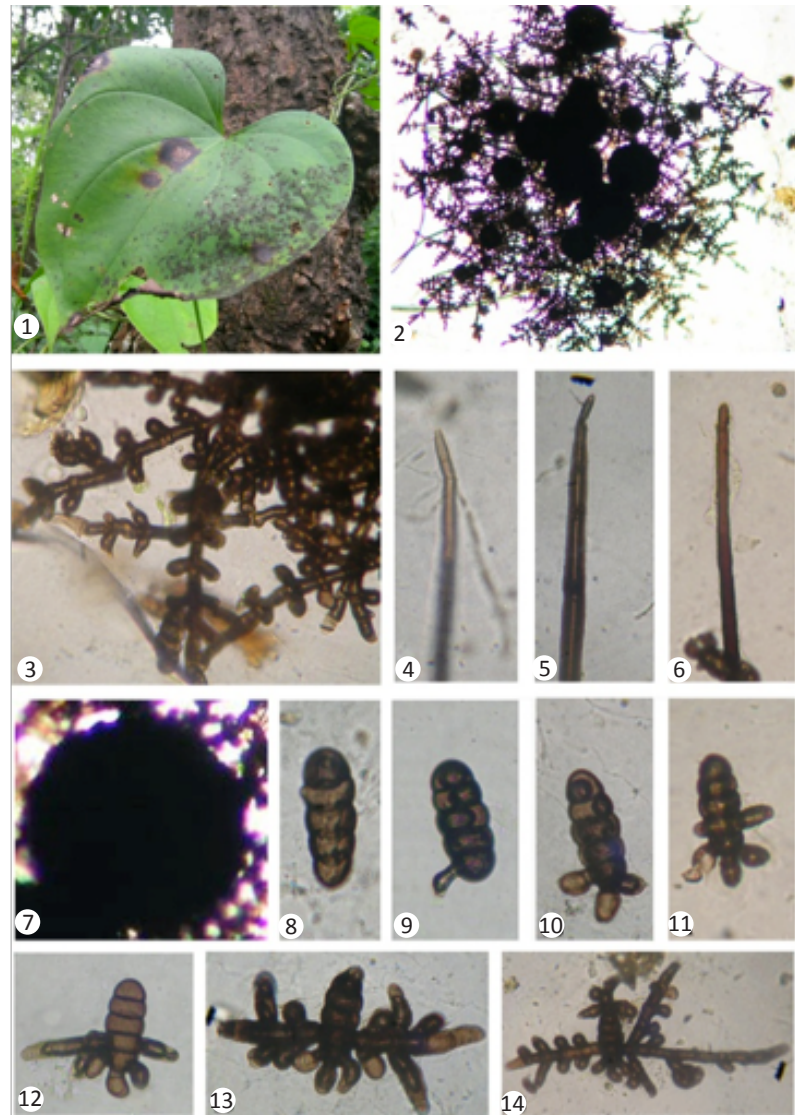

Image 8. Meliola dioscoregena

1 - Infected leaf of Dioscorea wightii; 2 - Colonies perithecia; 3 Appressoriate mycelium with phialides; 4-6 - Aipcal portion of the mycelial setae; 7 - Perithecium; 8 - ascospore, 9-14 - Germinating to colony forming ascospore;

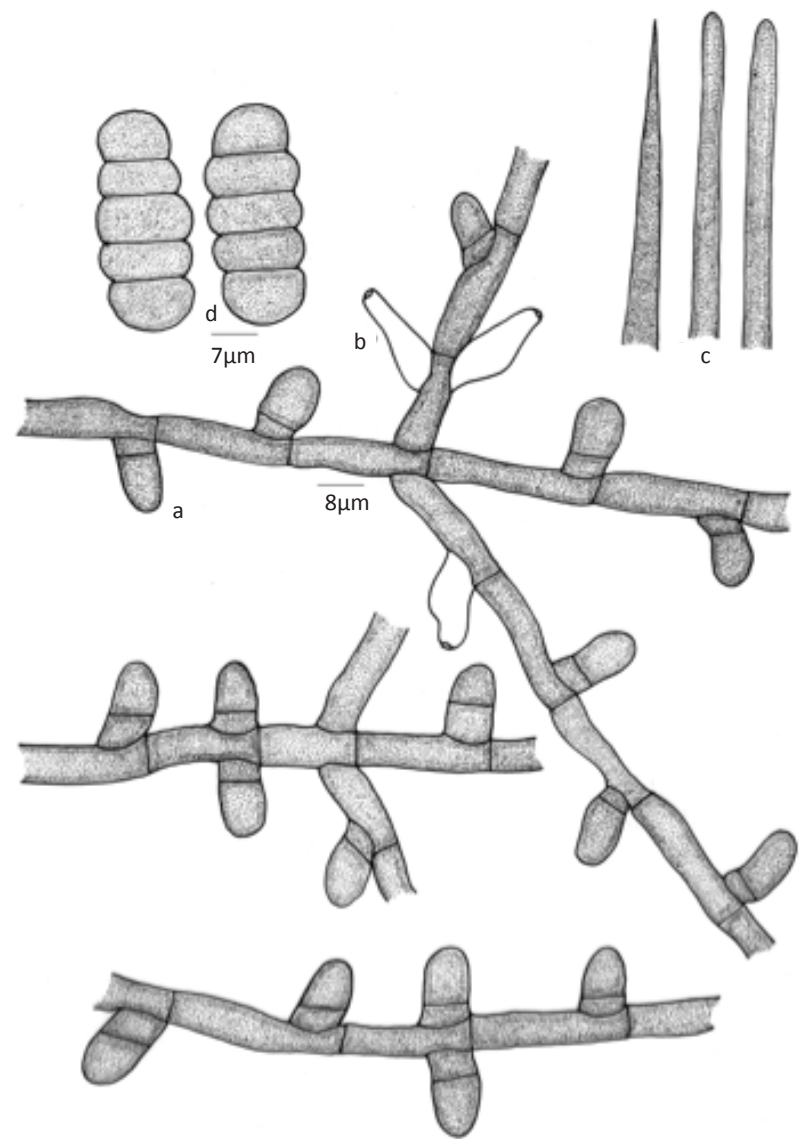

Figure 61. Meliola diospyri-buxifoliae

a - Appressorium; b - Phialide; c - Apical portion of mycelial setae; d - Ascospores 
acute-, 2-3-times dentate at the tip, up to $200 \mu \mathrm{m}$ long. Perithecia scattered, up to $210 \mu \mathrm{m}$ in diam.; ascospores cylindrical to oblong, 4-septate, slightly constricted at the septa, 35-40×12-15 $\mu \mathrm{m}$.

Material examined: TBGT 4962 (holotype), 26.xii.2009, Kerala, Wayanad, Padinharathara, Chennalode, on leaves of Dysoxylum sp. (Meliaceae), M.C. Riju. Part of the collection has been deposited in $\mathrm{HClO}$, New Delhi.

Meliola ptaeroxyli Doidge, M. carapace Hansf. \& Deight. and $M$. toonae Hosag. \& Sabu are the species that have simple and dentate mycelial setae. The present fungus differs from $M$. ptaeroxyli in not producing a pathogenic effect on the host, from $M$. carapace in having shorter appressoria (15-17 $\mu \mathrm{m}$ vs. 24-40 $\mu \mathrm{m})$ and smaller ascospores (35-40×12-15 vs. 51-58×19-23 $\mu \mathrm{m})$. It differs from $M$. toonae in having shorter appressoria (15-17 $\mu \mathrm{m}$ vs. 16-24 $\mu \mathrm{m}$ ) and shorter ascospores (35$40 \mu \mathrm{m}$ vs. 40-44 $\mu \mathrm{m}$ ) (Hansford 1961; Hu et al. 1996; 1999; Hosagoudar 1996, 2008, ).

The neck or apical portion of the phialides are unusually elongated, often variously bent and proliferate as hyphae by holding the phialoconidia in their neck.

Meliola ebeni Hosag. \& Archana, J. Threatened Taxa 2: 890, 2010. (Fig. 63)

Colonies amphigenous, subdense, up to $2 \mathrm{~mm}$ in diameter, confluent. Hyphae substraight to crooked, branching opposite to irregular at acute to wide angles, loosely to closely reticulate, cells $12-32 \times 4-8 \mu \mathrm{m}$. Appressoria opposite, alternate, unilateral, antrorse, subantrorse to retrorse, straight to curved, 11-26 $\mu \mathrm{m}$ long; stalk cells cylindrical to cuneate, $3-8 \mu \mathrm{m}$ long; head cells oblong, ovate, cylindrical, globose, straight to differently curved, entire to angular, 8-18x6-15 $\mu \mathrm{m}$. Phialides mixed with appressoria, opposite to alternate, ampulliform, 16-24x6-8 $\mu \mathrm{m}$. Mycelial setae, simple, straight, acute at the tip, up to $490 \mu \mathrm{m}$ long. Perithecia scattered to grouped, up to $160 \mu \mathrm{m}$ in diameter; ascospores obovoidal, 4-septate, slightly constricted at the septa, 38-45x12-16 $\mu \mathrm{m}$.

Material examined: HClO 48167 (holotype), TBGT 2903 (isotype), 10.ix.2006, Kerala, Thiruvananthapuram, JNTBGRI Campus, on leaves of Diospyrus ebenum Koenig (Ebenaceae), G.R. Archana et al. .

Crooked mycelium with variously curved appressoria with cylindrical to oblong head cells distinguishes this species from rest of the Meliola species known on the members of the family Ebenaceae (Hansford 1961; Hosagoudar et al.1997; Hu et al. 1997, 1999; Hosagoudar \& Agarwal 2008).
Meliola erumeliensis Hosag., Archana., Rajendraprasad \& Nazarudeen, J. Threatened Taxa 1: 347, 2009. (Fig. 64)

Colonies hypophyllous, subdense, up to $2 \mathrm{~mm}$ in diameter, confluent. Hyphae straight to substraight, branching opposite to irregular at acute to wide angles, loosely to closely reticulate, cells $11-32 \times 6-8$ $\mu \mathrm{m}$. Appressoria mostly opposite, alternate, straight to curved, antrorse, subantrorse to retrorse, 9-22 $\mu \mathrm{m}$ long; stalk cells cylindrical to cuneate, 2-8 $\mu \mathrm{m}$ long; head cells ovate, oblong, entire to predominantly angular, 8-16x8$11 \mu \mathrm{m}$. Phialides mixed with appressoria, numerous, opposite to alternate, ampulliform, 11-22x6-10 $\mu \mathrm{m}$. Mycelial setae simple, crooked, uncinate, obtuse at the tip, up to $294 \mu \mathrm{m}$ long. Perithecia globose, scattered to grouped, up to $176 \mu \mathrm{m}$ in diameter; ascospores obovoidal, 4-septate, constricted at the septa, 36-43x17-21 $\mu \mathrm{m}$.

Material examined: HClO 46831 (holotype), TBGT 2172 (isotype), 16.iii.2006, Kerala, Idukki, Peeramed, Erumeli range, Murinjapuzha, on the leaves of Drypetes

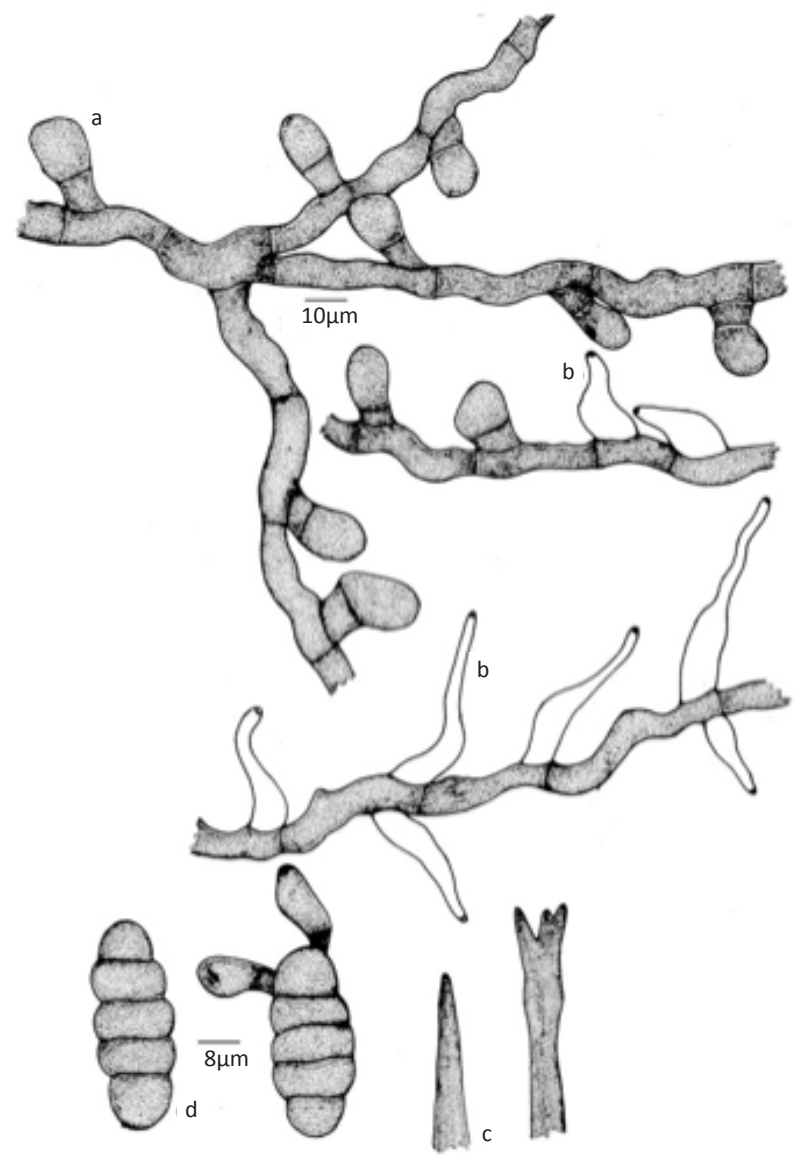

Figure 62. Meliola dysoxyligena

a - Appressorium; b - Phialide; c - Apical portion of mycelial setae; d - Ascospores 


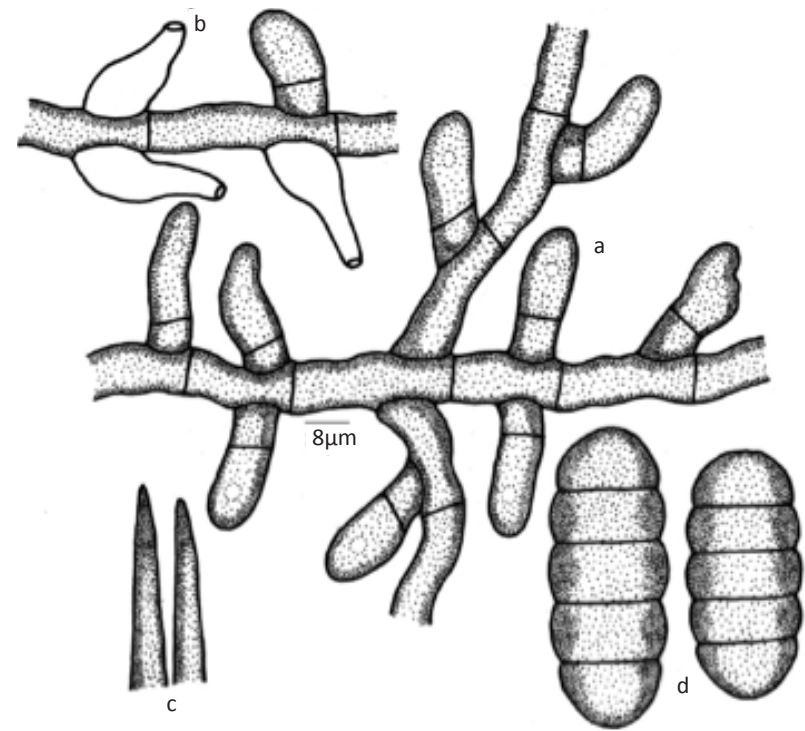

Figure 63. Meliola ebeni

a - Appressorium; b - Phialide; c - Apical portion of mycelial setae; d - Ascospores

elata (Bedd.) Pax \& Hoffm. (Euphorbiaceae), A. Nazaruddin \& M. Rajendraprasad.

Meliola drypeticola Hosag. is the only species known on the host genera Drypetes and Epiprinus from the Western Ghats region of peninsular India (Hosagoudar 1996). Meliola erumeliensis distinctly differs from it in having crooked and uncinate mycelial setae.

Meliola erythrinae Sydow var. indica Hosag. \& Jacob. Indian J. Sci. Technol. 2(6): 23, 2009. (Fig. 65).

Colonies epiphyllous, thin, up to $3 \mathrm{~mm}$ in diameter, confluent. Hyphae substraight to slightly undulate, branching opposite at acute to wide angles, loosely to closely reticulate, cells $21-41 \times 4-7 \mu \mathrm{m}$. Appressoria alternate, $5 \%$ unilateral, $5 \%$ opposite, antrorse to spreading, straight to curved, 12-17 $\mu \mathrm{m}$ long; stalk cells cylindrical to cuneate, $2-5 \mu \mathrm{m}$ long; head cells subglobose, clavate, entire, 9-12×12-15 $\mu \mathrm{m}$. Phialides mixed with appressoria, opposite to alternate, ampulliform, 14-22x7-10 $\mu \mathrm{m}$. Mycelial setae numerous, scattered to grouped around perithecia, straight, simple, acute to obtuse at the tip, up to $410 \mu \mathrm{m}$ long. Perithecia scattered to grouped, verrucose, up to $160 \mu \mathrm{m}$ in diam.; ascospores cylindrical to subellipsoidal, 4-septate, constricted at the septa, 33-43×12-17 $\mu \mathrm{m}$.

Materials examined: HCIO 48253 (holotype), TBGT 2992 (isotype), 12.xi.2007, Kerala, Thrissur, Vazhachal, near Lower Sholayar dam, on leaves of Erythrina variegata L. (E. indica Lam.) (Fabaceae), Jacob Thomas et al.

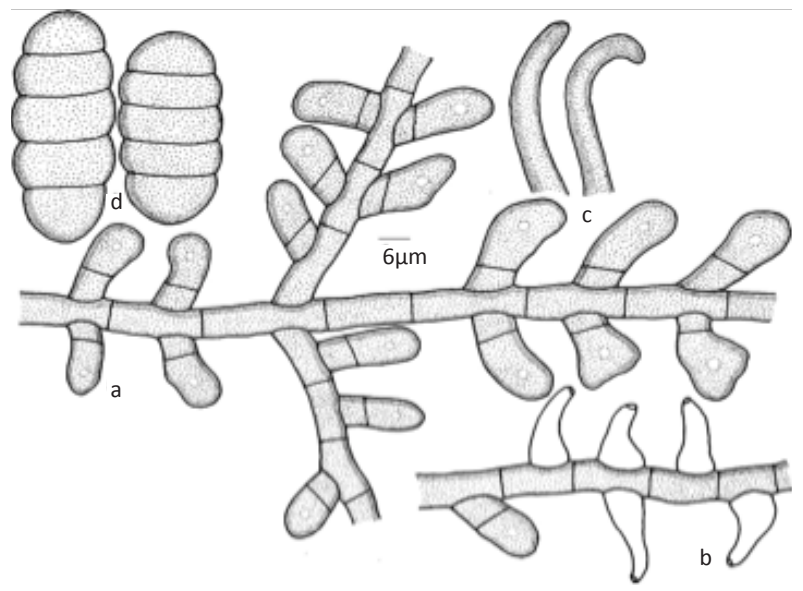

Figure 64. Meliola erumeliensis

a - Appressorium; b - Phialide; c - Apical portion of mycelial setae; d - Ascospores

The present collection is similar to Meliola erythrinae but the variety differs from the var. erythrinae in having $5 \%$ opposite appressoria.

Meliola euonymi Stev. ex Hansf., Sydowia Beih.1:108, 1957; Beih.2: 342, 1961. (Fig. 66).

Colonies amphigenous, subdense, up to $2 \mathrm{~mm}$ in diam., confluent. Hyphae substraight to flexuous, branching alternate at acute to wide angles, cells 1634x6-8 $\mu \mathrm{m}$. Appressoria alternate, straight to slightly curved, antrorse, subantrorse to retrorse, 24-42 $\mu \mathrm{m}$ long; stalk cells cylindrical to cuneate, 8-28 $\mu \mathrm{m}$ long; head cells ovate, globose, clavate, oblong, irregularly deeply lobate, rarely angular, 14-27x19-24 $\mu \mathrm{m}$. Phialides mixed with appressoria, alternate, unilateral, ampulliform, 19-26x4-7 $\mu \mathrm{m}$. Mycelia setae simple, scattered, straight to slightly curved, acute to obtuse at the tip, up to $420 \mu \mathrm{m}$ long. Perithecia scattered to loosely aggregated, up to $110 \mu \mathrm{m}$ in diam.; ascospores oblong to cylindrical, 3-septate, slightly constricted at the septa, 48-58x17-23 $\mu \mathrm{m}$.

Materials examined: TBGT 5746, 12.xi.2007, Tamil Nadu, Kodaikanal, Bhoothakanal, on leaves of Eunymous sp. (Celastraceae), R. Nithytharani.

This species was known only from a single collection from Philippines (Hansford 1961).

Meliola exacigena Hosag., Archana \& Kandavel, J. Scient. Trans. Environ. Techn. 1: 53, 2007. (Fig. 67)

Colonies hypophyllous, dense, up to $2 \mathrm{~mm}$ in diameter, confluent. Hyphae straight to substraight, branching mostly opposite, often alternate at acute to wide angles, loosely to closely reticulate, cells $12-26 \times 6-$ 


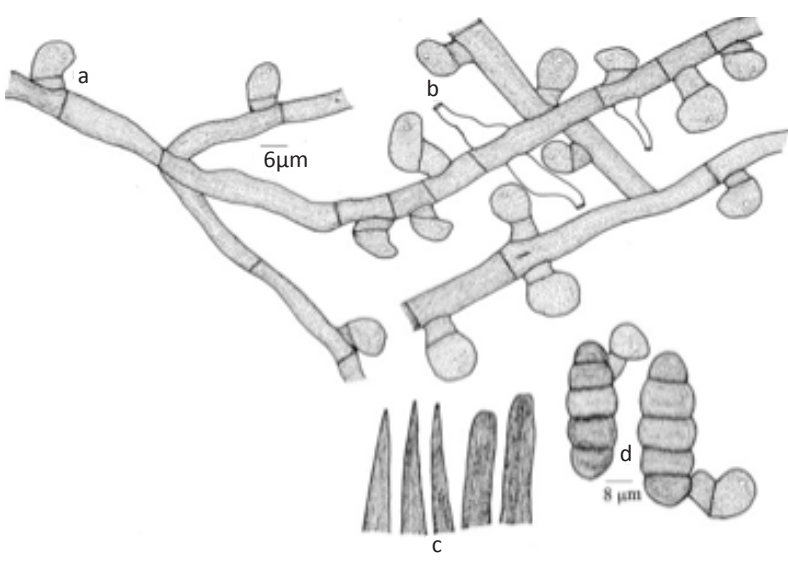

Figure. 65. Meliola erythrinae var. indica

a - Appressorium; b - Phialide; c - Apical portion of mycelial setae d - Ascospores

$10 \mu \mathrm{m}$. Appressoria alternate to unilateral, antrorse, subantrorse to retrorse, straight to curved,16-29 $\mu \mathrm{m}$ long; stalk cells cylindrical to cuneate, 6-10 $\mu \mathrm{m}$ long; head cells ovate, oblong, entire to angular, 9-19x9$16 \mu \mathrm{m}$. Phialides mixed with appressoria, alternate, ampulliform, 12-19x6-10 $\mu \mathrm{m}$. Mycelial setae simple, straight, acute at the tip, up to $530 \mu \mathrm{m}$ long. Perithecia scattered to grouped, globose, up to $235 \mu \mathrm{m}$ in diameter; ascospores obovoidal, 4-septate, constricted at the septa, 38-42x14-18 $\mu \mathrm{m}$.

Material examined: HClO 47699 (holotype), TBGT 2721(isotype), 18.vii.2006 Tamil Nadu, Kodaikanal, Mathikettan shola, on leaves of Exacum sp.

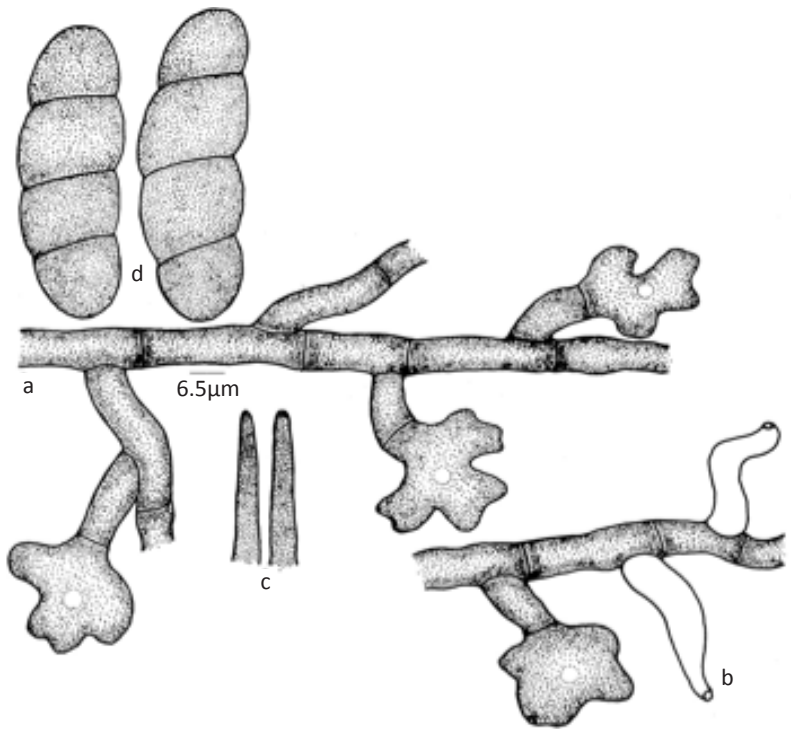

Figure 66. Meliola euonymi

a - Appressorium; b - Phialide; c - Apical portion of mycelial setae; d - Ascospores
(Gentianaceae), B. Bhairavi.

Meliola exaci Hosag. is the only Meliola species known on the host genus Exacum (E. tetragonum) from Maharashtra (Hansford 1961; Hosagoudar et al. 1997; Hosagaoudar 1996; Hu et al. 1996 1999; Mebey \& Hawkswoth 1997; Mibey \& Cannon 1999; Patil \& Mahamulkar 1999). M. exacigena differs from it in having straight mycelium, having entire to angular head cells of the appressoria, longer mycelial setae and larger ascospores.

Meliola filicii Hosag. var. indica Hosag. \& Archana, J. Threatened Taxa 2: 891, 2010. (Fig. 68)

Colonies hypophyllous, dense, up to $2 \mathrm{~mm}$ in diameter, confluent. Hyphae straight to substraight, branching opposite, alternate at acute to wide angles, loosely to closely reticulate, cells 11-24x4-7 $\mu \mathrm{m}$. Appressoria opposite, alternate, antrorse, subantrorse to retrorse, 8-15 $\mu \mathrm{m}$ long; stalk cells cylindrical to cuneate, 2-6 $\mu \mathrm{m}$ long; head cells ovate, globose, entire to angular, straight to curved, 6-11x6-8 $\mu \mathrm{m}$. Phialides few, mixed with appressoria, opposite to alternate, ampulliform, 9-16x4$7 \mu \mathrm{m}$. Mycelial setae, simple, straight, acute, dentate to furcate at the tip, up to $350 \mu \mathrm{m}$ long. Perithecia scattered to grouped, up to $196 \mu \mathrm{m}$ in diameter; ascospores obovoidal, 4-septate, slightly constricted at the septa, 25-37x8-13 $\mu \mathrm{m}$.

Material examined: $\mathrm{HClO} 48168$ (holotype), TBGT 2904 (isotype), 20.ii.2007, Kerala, Thiruvananthapuram, Ponmudi, on leaves of Filicium decipiens (Wight \& Arn.) Thw. (Sapindaceae), G.R. Archana et al.

The variety indica differs from the variety filicii in having only dentate to furcate apical tip of the mycelial setae (Hosagoudar 1996).

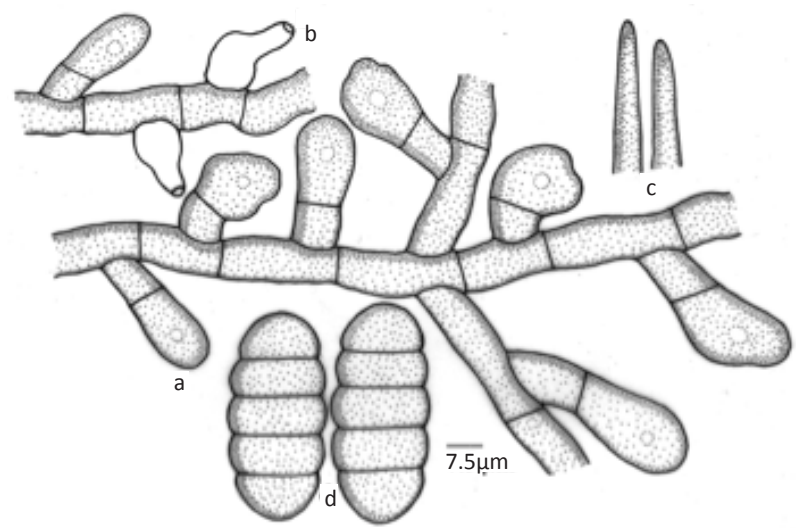

Figure 67. Meliola exacigena

a - Appressorium; b - Phialide; c - Apical portion of mycelial setae; d - Ascospores 
Meliola garugae Stev. \& Rold., Philippine J. Sci. 56: 67,1935; Hansf., Sydowia Beih. 2: 399, 1961; Hosag. \& Robin, J. Threatened Taxa 3(3): 1786, 2011. (Imge. 9, Fig. 69)

Colonies amphigenous, mostlyepiphyllous, up to $3 \mathrm{~mm}$ in diameter, confluent. Hyphae straight to substraight, branching mostly opposite to alternate at acute angles, loosely reticulate, cells 24-36x5-7 $\mu \mathrm{m}$. Appressoria alternate to unilateral, antrorse to subantrorse, 14-19 $\mu \mathrm{m}$ long; stalk cells cylindrical to cuneate, 5-7 $\mu \mathrm{m}$ long; head cells ovate, globose, entire,10-12x7-10 $\mu \mathrm{m}$. Phialides mixed with appressoria, alternate to opposite, ampulliform, neck elongated, 19-24x7-10 $\mu \mathrm{m}$. Mycelial setae numerous, scattered, straight, dentate, cristate, bifid to obtuse at the tip, up to $370 \mu \mathrm{m}$ long. Perithecia scattered, up to $170 \mu \mathrm{m}$ in diameter; ascospores oblong to cylindrical, 4-septate, constricted at the septa, 3643x14-17 $\mu \mathrm{m}$.

Materials examined: HCIO 48791 (holotype), TBGT 3167, 29.vi. 2007, On leaves of Garuga pinnata Roxb. (Burseraceae), Vazhoor, Kottayam, Kerala, P. J. Robin.

This species was known in Garuga sp. from Philippines and was known only from a single collection (Hansford 1961).

Meliola gluticola Hosag., Sabeena \& Jacob Thomas, Taprobanica 2(2): 95, 2010. (Fig. 70)

Colonies amphigenous, mostly hypophyllous, thin, upto $4 \mathrm{~mm}$ in diameter, confluent. Hyphae straight to substraight, branching opposite at acute to wide angles, cells 13-20x6-9 $\mu \mathrm{m}$. Appressoria alternate, closely arranged on the hyphae antrorse to subantrorse, 15-20 $\mu \mathrm{m}$ long; stalk cells cylindrical to cuneate, 2-6 $\mu \mathrm{m}$ long; head cells ovate, entire, $13-15 \times 6-9 \mu \mathrm{m}$. Phialides mixed

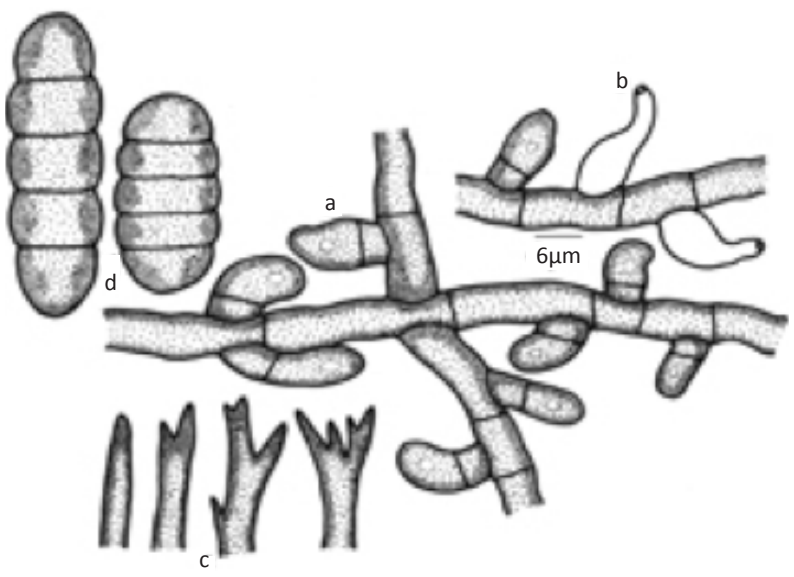

Figure 68. Meliola filicii var. indica a - Appressorium; b - Phialide; c - Apical portion of mycelial setae; d-Ascospores with appressoria, alternate to opposite, ampulliform 15-22x6-9 $\mu \mathrm{m}$. Mycelial setae simple, straight, acute to obtuse at the tip, up to $330 \mu \mathrm{m}$ long. Perithecia scattered, up to $110 \mu \mathrm{m}$ in diameter; ascospores cylindrical, 4-septate, constricted at the septa, 39-44×15-17 $\mu \mathrm{m}$.

Material examined: HCIO 48337 (holotype), TBGT 3058 (isotype), 10.x.2007, Kerala, Thiruvananthapuram, Palode, JNTBGRI Campus, on leaves of Gluta travancorica L. (Anacardiaceae), A. Sabeena et al.

Gluta travancorica $\mathrm{L}$. is an endemic plant and Meliola glutae is known to infect this plant (Hosagoudar 1996, 1998; Hosagoudar \& Agarwal 2008; Hosagoudar et al. 1997). However, differs from it in having regularly antrorse to subantrorse appressoria with ovate to oblong and entire head cells. The colonies of both these species were mixed together but can be easily distinguished based on the above characters.

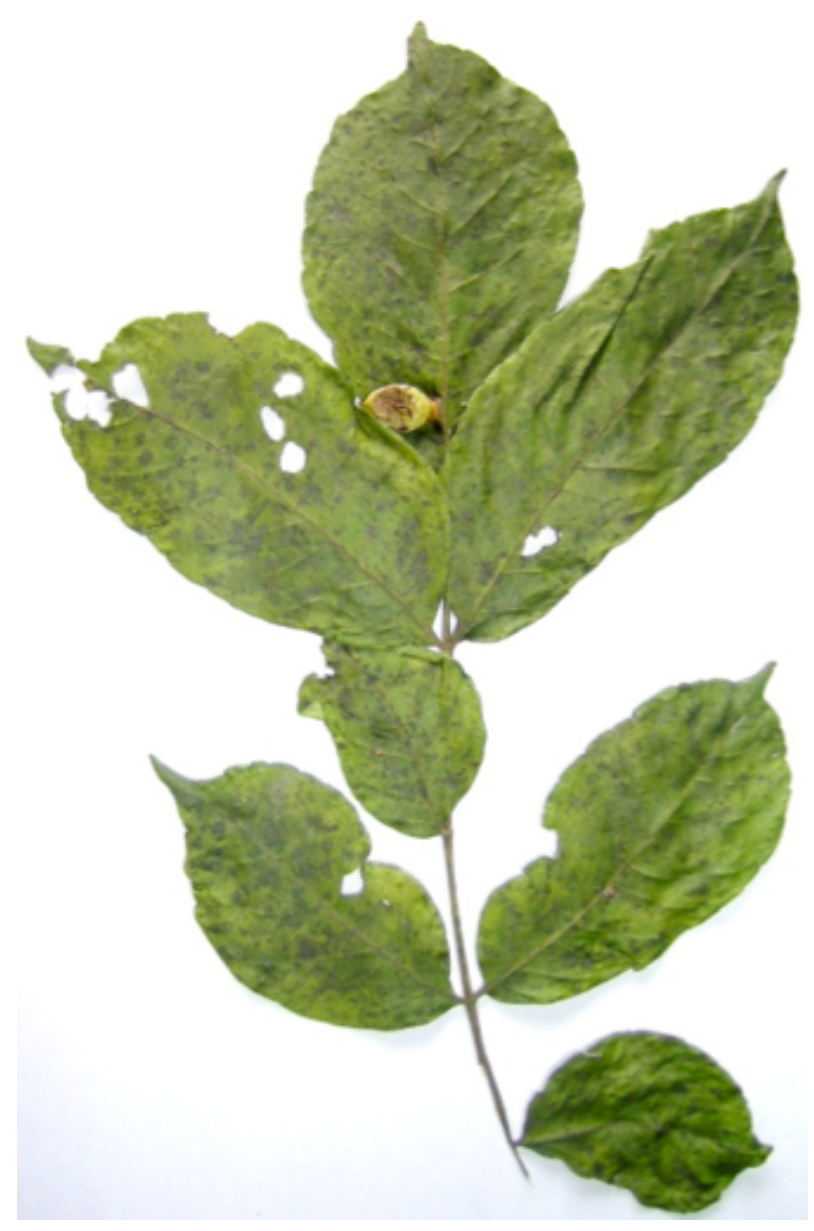

Image 9. Meliola garugae infected leaves 


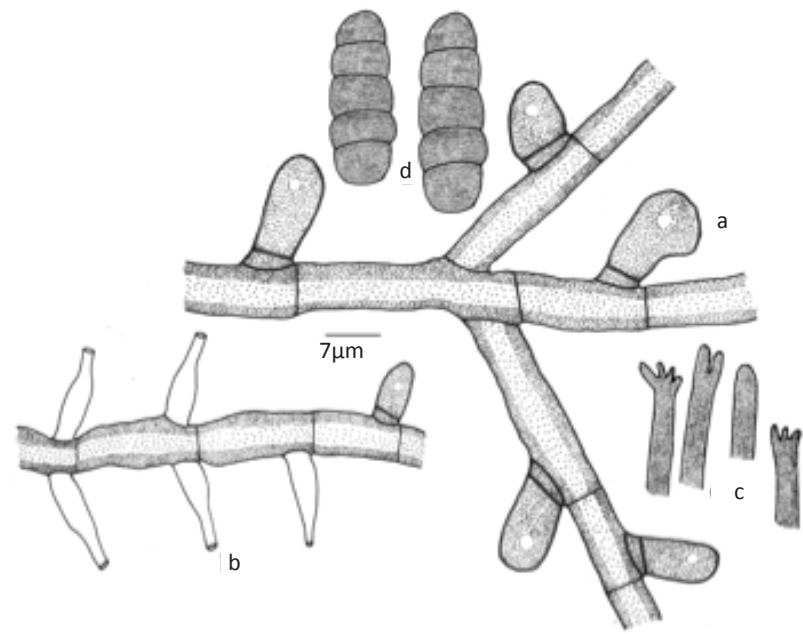

Figure 69. Meliola garugae

a - Appressorium; b - Phialide; c - Apical portion of mycelial setae; d-Ascospores

Meliola gouaniae Hansf. var. keralica Hosag. \& Robin, J. Threatened Taxa 3(5): 1785, 2011. (Fig. 71)

Colonies epiphyllous, thin, up to $4 \mathrm{~mm}$ in diameter, confluent. Hyphae straight to substraight, branching mostly opposite at acute angles, loosely reticulate, cells 19-29x5-7 um. Appressoria mostly alternate, unilateral, antrorse to subantrorse, $12-17 \mu \mathrm{m}$ long; stalk cells cylindrical to cuneate, 2-7 $\mu \mathrm{m}$ long; head cells ovate, globose, entire, angular to slightly lobate, 10-14x7$10 \mu \mathrm{m}$. Phialides mixed with appressoria, alternate to opposite, unilateral, ampulliform, 21-29x5-7 $\mu \mathrm{m}$. Mycelial setae scattered, simple, straight, obtuse to dentate at the tip, up to $420 \mu \mathrm{m}$ long. Perithecia scattered, globose, up to $178 \mu \mathrm{m}$ in diameter; ascospores obovoidal, 4-septate, constricted at the septa, 3138x12-14 $\mu \mathrm{m}$, wall smooth.

Materials examined: HClO 48793 (holotype), TBGT 3169 (isotype), 12.iii.2007, Kerala, Kottayam, Ponthanpuzha, on leaves of Gouania sp. (Rhamnaceae), P. J. Robin.

The present taxon is similar to Meliola gouniae Hansf. known on Gouania sp. from Sierra Leone and Java. However, the new variety differs from the var. gouaniae in having longer and not torulose but dentate mycelial setae.

Meliola gouaniicola Hosag. \& Robin, Bioscience Discovery 2(2): 266, 2011. (Fig. 72)

Colonies amphigenous, dense, velvety, up to $4 \mathrm{~mm}$ in diameter, confluent. Hyphae substraight to slightly undulate, branching opposite to irregular at acute angles,

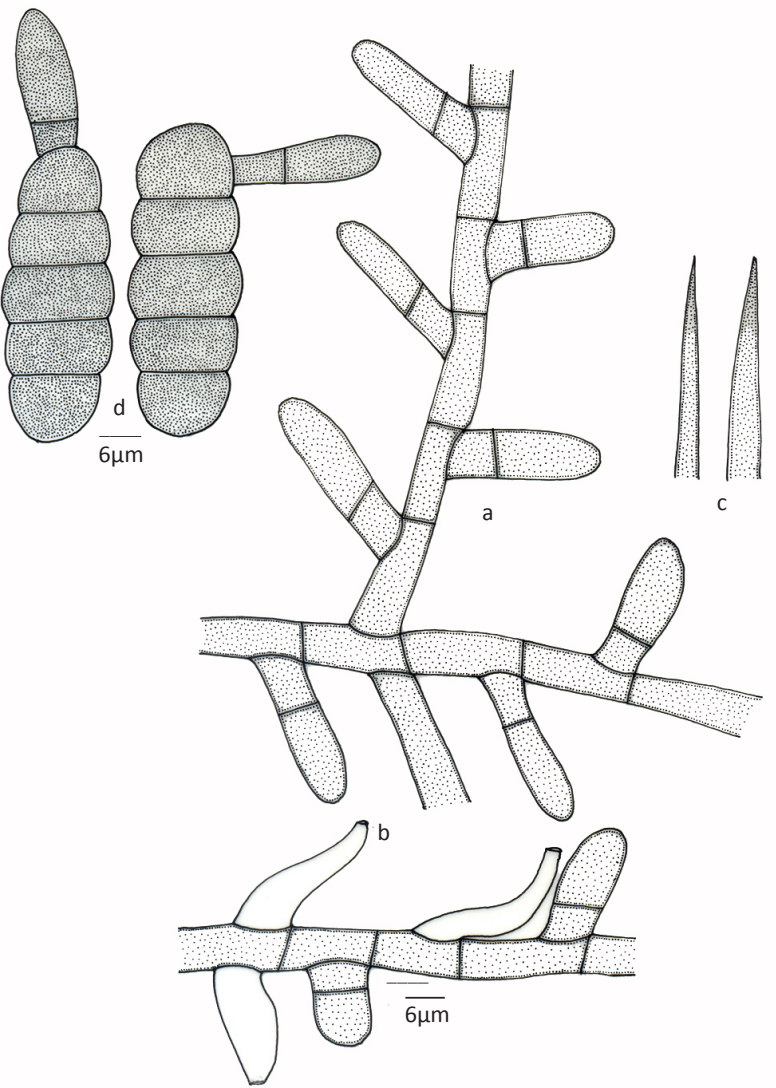

Figure 70. Meliola gluticola

a - Appressorium; b - Phialide; c - Apical portion of mycelial setae; d - Ascospores

loosely reticulate, cells 22-26x4-7 $\mu \mathrm{m}$. Appressoria alternate to $5 \%$ unilateral, antrorse to sub antrorse, 13-18 $\mu \mathrm{m}$ long; stalk cells cylindrical to cuneate, 2-6 $\mu \mathrm{m}$ long; head cells globose, subglobose to oblong, 9-13×6$13 \mu \mathrm{m}$. Phialides mixed with appressoria, opposite to alternate, ampulliform, 15-22x4-6 $\mu \mathrm{m}$. Mycelial setae scattered, grouped around perithecia straight, simple, obtuse at the tip, up to $360 \mu \mathrm{m}$ long. Perithecia scattered, verrucose, up to $121 \mu \mathrm{m}$ in diameter; ascospores oblong to ellipsoidal, 4-septate, constricted at the septa, 2833x11-12 $\mu \mathrm{m}$.

Materials examined: TBGT 4654 (holotype), HCIO 50737 (isotype), 24.xi.2007, Karnataka, Coorg, Galibeedu, on leaves of Gouania sp. (Rhammanaceae), P.J. Robin.

Meliola gouniae Hansf. is known on Gouniae sp. from Sierra Leone and Java. However the M. gouaniicola differs from M. gouaniae in having striagt and obtuse mycelia setae torulose but dentate mycelial setae. 


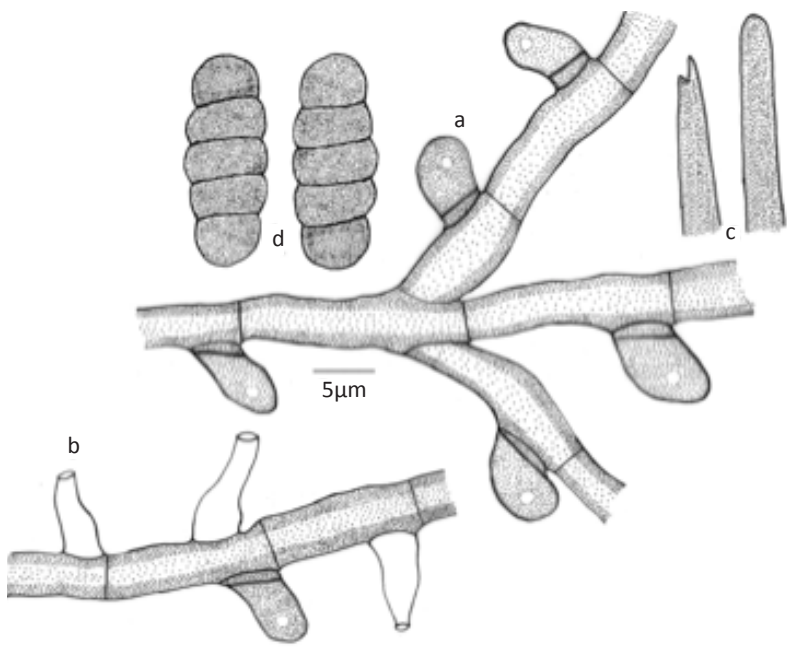

Figure 71. Meliola gouaniae var. keralica

a - Appressorium; b - Phialide; c - Apical portion of mycelial setae; $\mathrm{d}$ - Ascospores

Meliola harpullicola sp. nov. Hosag. \& Sabeena

(Fig. 73; MycoBank 803914)

Colonies epiphyllous, subdense to dense, up to $4 \mathrm{~mm}$ in diameter, confluent. Hyphae straight to substraight, branching opposite to unilateral at acute to wide angles, loosely to closely reticulate, cells $22-37 \times 5-10$ $\mu \mathrm{m}$. Appressoria alternate to unilateral, antrorse to subantrorse, 15-20 $\mu \mathrm{m}$ long; stalk cells cylindrical to cuneate, 2-5 $\mu \mathrm{m}$ long; head cells ovate, entire, 10-15x7$3 \mu \mathrm{m}$. Phialides numerous, mixed with appressoria, alternate to opposite, ampulliform, 10-25x5-7 $\mu \mathrm{m}$. Mycelial setae numerous, scattered, simple, straight to uncinate, up to $320 \mu \mathrm{m}$ long, obtuse , 1-3 dentate but predominantly cristate at the tip. Perithecia scattered, orbicular, up to $170 \mu \mathrm{m}$ in diam.; ascospores oblong, 4-septate, constricted at the septa, 37-42×12-15 $\mu \mathrm{m}$.

Materials examined: TBGT 5749 (holotype), 3.i.2011, Kerala, Kollam, Chozhiakodu, on leaves of Harpullia arborea (Blanco) Radlk. (H. imbricate (Blume) Thwaites) (Sapindaceae), V.B. Hosagoudar et al. Part of the collection is deposited in $\mathrm{HClO}$, New Delhi.

Etymology: Named after the host genus.

This species stands distinct from the other Meliola species known on the members of Sapindaceae in having straight to uncinate mycelial setae having obtuse to cristate apical tip (Hansford 1961; Hosagoudar 1996, 2008; Hu et al. 1996, 1999).

Meliola homonoiae Hosag. \& Sabeena, Bulletin of Basic \& Applied Plant Biology 1(1): 49, 2011. (Fig. 74)

Colonies mostly hypophyllous, subdense, velvety, up to $2 \mathrm{~mm}$ in diameter, confluent. Hyphae crooked,

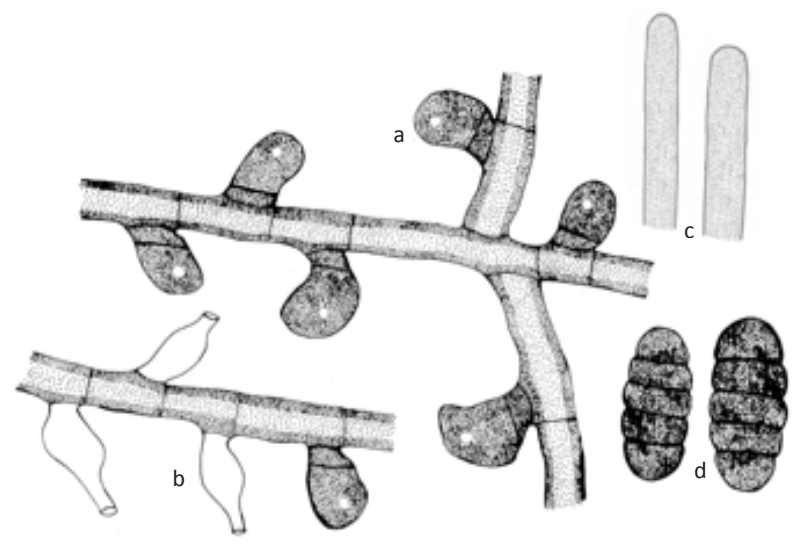

Figure 72. Meliola gouaniicola

a - Appressorium; b - Phialide; c - Apical portion of mycelial setae; $\mathrm{d}$ - Ascospores

branching opposite to unilateral at acute to wide angles, loosely to closely reticulate, cells $15-32 \times 7-10 \mu \mathrm{m}$. Appressoria alternate to unilateral, straight to curved, antrorse to subantrorse, 17-22 $\mu \mathrm{m}$ long; stalk cells cylindrical to cuneate, 5-7 $\mu \mathrm{m}$ long; head cells globose to ovate, entire, angular to lobate, $12-15 \times 10-15 \mu \mathrm{m}$. Phialides mixed with appressoria, opposite, alternate to unilateral, ampulliform, 17-32×5-12 $\mu \mathrm{m}$. Mycelial setae scattered, simple, straight, up to $650 \mu \mathrm{m}$ long, acute to obtuse at the tip. Perithecia scattered, up to $150 \mu \mathrm{m}$ in diam.; ascospores cylindrical, 4-septate, constricted at the septa, 40-50x17-22 $\mu \mathrm{m}$.

Material examined: TBGT 5097 (Holotype p.p.), 25.iii.2009, Kerala, Kottayam, Koruthodu, on leaves of Homonoia riparia Lour. (Euphorbiaceae), V. Gireesh Kumar et al. Part of the collection has been deposited in $\mathrm{HClO}$, New Delhi.

Meliola romosii Sydow is known on this host from Philippines and India (Hansford 1961; Hosagoudar 1996). However, the present new species differs from it in having crooked hyphae, longer mycelial setae and ascospores.

Meliola hoveniae Hosag., Dhivaharan \& Riju, J. Sci. Trans. Techn. 4(4): 166, 2011. (Fig. 75)

Colonies amphigenous, thin, confluent, 1-2 $\mathrm{mm}$ in diameter. Hyphae flexuous, branching alternate at acute to wide angles, loosely reticulate, cells 25-27x7-9 $\mu \mathrm{m}$. Appressoria alternate, straight to curved, antrorse to retrorse, 24-25 $\mu \mathrm{m}$ long; stalk cells cylindrical to cuneate, 7-10 $\mu \mathrm{m}$ long; head cells ovate, globose, truncate to attenuated at the apex, sublobate, 15-17x12-15 $\mu \mathrm{m}$. Phialides on borne on a separate mycelial branch, alternate, unilateral, opposite, ampulliform, 17-22x7-10 


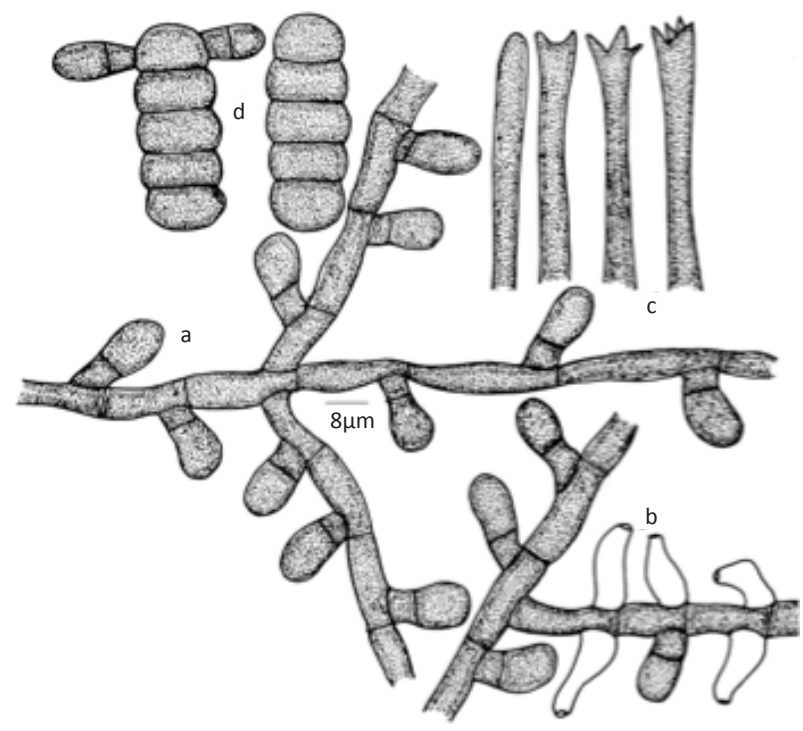

Figure 73. Meliola harpullicola sp. nov.

a - Appressorium; b - Phialide; c - Apical portion of mycelial setae; d - Ascospores

$\mu \mathrm{m}$. Mycelial setae grouped around perithecia, simple, straight, acute to obtuse at the tip, up to $360 \mu \mathrm{m}$ long. Perithecia scattered to connate, globose, up to $205 \mu \mathrm{m}$ in diam.; ascospores cylindrical to obovoidal, 4-septate, constricted at the septa, 42-45×15-17 $\mu \mathrm{m}$.

Materials examined: TBGT 4442 (holotype), $\mathrm{HClO}$ 50525 (isotype), 25.x.2007, Tamil Nadu, Kodaikanal, Kukkal shola, Periyakanal, on leaves of Hovenia acerba Lindl. (Rhamnaceae), V. Dhivaharan et al.

Meliola ziziphi Hansf. \& Theiss. and Meliola krugiodendr Cif. can be compared with the present species. However, differs from both in having angular and truncate head cells of appressoria (Hansford 1961).

Meliola hugoniae Hanf. \& Deight., Mycol. Pap. 23: 5, 1948; Hansf. Sydowia Beih. 2: 91,1961; Hosag., Jacob Thomas \& Agarwal, Taprobanica 3(1): 43, 2011. (Fig. 76)

Colonies epiphyllous, subdense to dense, velvety, up to $2 \mathrm{~mm}$ in diameter. Hyphae straight to substraight, branching mostly opposite at acute to wide angles, loosely to closely reticulate, cells $15-29 \times 4-7 \mu \mathrm{m}$. Appressoria opposite, about $2 \%$ alternate to unilateral, straight to curved, antrorse to spreading, 13-20 $\mu \mathrm{m}$ long; stalk cells cylindrical to cuneate, 2-5 $\mu \mathrm{m}$ long; head cells ovate to oblong, entire, broadly rounded at the apex, 11-15x6-9 $\mu \mathrm{m}$. Phialides mixed with appressoria, alternate to opposite, ampulliform, 17-26x5-7 $\mu \mathrm{m}$. Mycelial setae scattered to grouped around perithecia, simple, straight, acute to obtuse at the tip, up to $1200 \mu \mathrm{m}$ long. Perithecia scattered, up to $160 \mu \mathrm{m}$ in diam.; ascospores obovoidal,

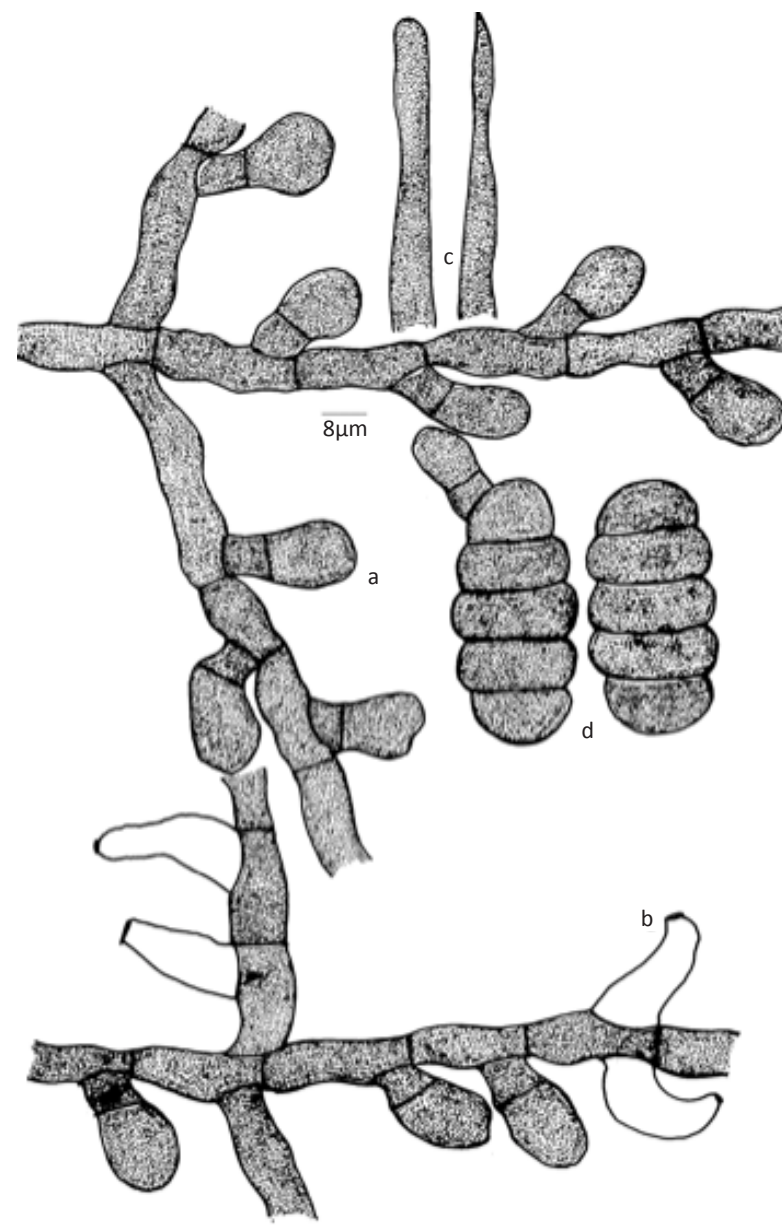

Figure 74. Meliola homonoiae

a - Appressorium; b - Phialide; c - Apical portion of mycelial setae; d - Ascospores

4-septate, constricted at the septa, 28-41x11-17 $\mu \mathrm{m}$.

Materials examined: $\mathrm{HClO}$ 49036, TBGT 3291, 28.ii.2007, Kerala, Kannur, Aaralam Wildlife Sanctuary, on leaves of Hugonia belli Sedgwick (Linaceae), Jacob Thomas et al.

This is the only species known on this host genus from India (Hosagoudar 1996, 2008).

Meliola ichnocarpi-volubili Hansf., Sydowia 16: 320, 1963. (Fig. 77)

Colonies amphigenous, mostly epiphyllous, dense, velvety, up to $3 \mathrm{~mm}$ in diameter, confluent and covering almost an entire upper surface of the leaves. Hyphae straight to substraight, branching opposite at acute to wide angles, closely reticulate, cells $16-29 \times 4-7 \mu \mathrm{m}$. Appressoria alternate, about $5 \%$ unilateral, straight to curved, antrorse to spreading, 9-15 $\mu \mathrm{m}$ long; stalk cells cylindrical to cuneate, up to $3 \mu \mathrm{m}$ long; head cells globose to subglobose, ovate, entire, $7-12 \times 7-10 \mu \mathrm{m}$. 


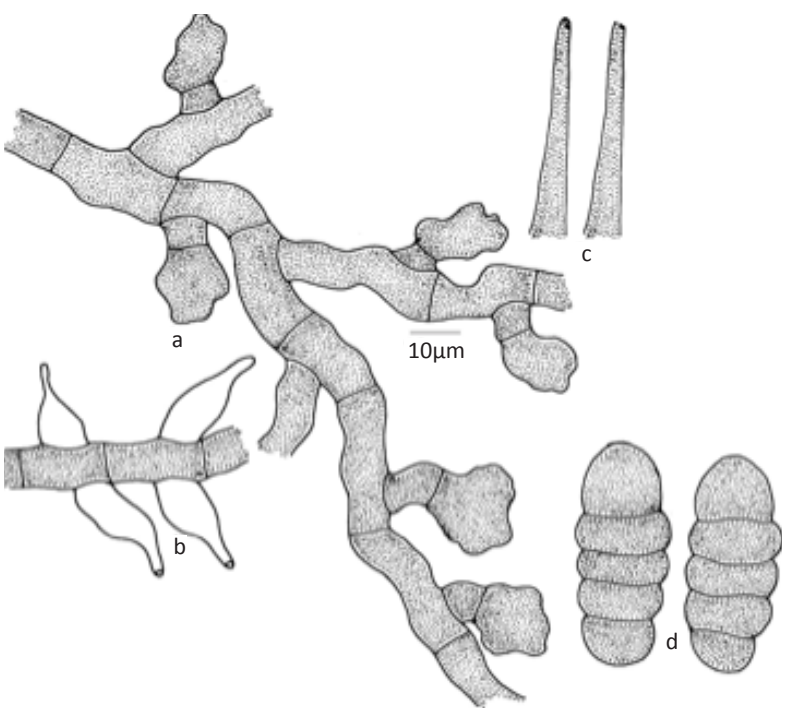

Figure 75. Meliola hoveniae

a - Appressorium; b - Phialide; c - Apical portion of mycelial setae d - Ascospores

Phialides mixed with appressoria, alternate to opposite, ampulliform, 14-19x4-10 $\mu \mathrm{m}$. Mycelial setae numerous, scattered, straight, simple, acute to obtuse at the tip, up to $420 \mu \mathrm{m}$ long. Perithecia scattered, verrucose, up to $130 \mu \mathrm{m}$ in diam.; ascospores cylindrical to obovoidal, 4-septate, constricted, 26-38x12-14 $\mu \mathrm{m}$.

Materials examined: HCIO 49017, TBGT 3272, 18.xi.2007, Kerala, Thiruvananthapuram, Peppara Wildlife Sanctuary, near Peppara Dam, on leaves of Quirivelia frutescens (L.) M.R. Almeida \& S.M. Almieda (Ichnocarpus frutescens (L.) R. Br (Apocyanaceae), Jacob Thomas.

Meliola ichnocarpiii Hansf. \& Thirum and Meliola ichnocarpii-volubilii Hansf. are known on this host genus. The former species differs from the latter in having longer appressoria (15-30) and larger ascospores (40-48×20-28 $\mu \mathrm{m})$. Hence, the present species is accommodated in the latter species. This species was known on Ichnocarpus volubilis from Philippines and is reported here for the first time from India (Hansford 1961; Hosagoudar 1996, 2008).

Meliola kakachiana Hosag. var. poochiparensis Hosag. \& Sabeena, Plant Pathology \& Quarantine 3(1): 12, 2012. (Fig. 78)

Colonies hypophyllous, subdense, up to $3 \mathrm{~mm}$ in diameter, confluent. Hyphae straight to substraight, branching opposite to unilateral at acute to wide angles, loosely to closely reticulate, cells $17-35 \times 5-7 \mu \mathrm{m}$. Appressoria alternate, about $40 \%$ opposite, antrorse to subantrorse, 12-17 $\mu \mathrm{m}$ long; stalk cells cylindrical

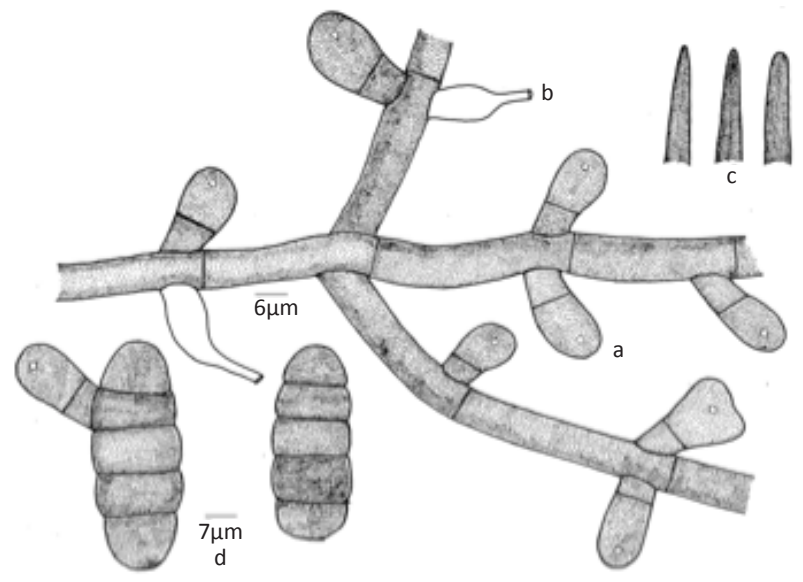

Figure 76. Meliola hugoniae

a - Appressorium; b - Phialide; c - Apical portion of mycelial setae; d - Ascospores

to cuneate, 2-5 $\mu \mathrm{m}$ long; head cells globose, entire, 10-12x12-15 $\mu \mathrm{m}$. Phialides mixed with appressoria, opposite, ampulliform, 12-20x5-10 $\mu \mathrm{m}$. Mycelial setae numerous, scattered, simple, straight, up to $950 \mu \mathrm{m}$ long, acute, obtuse to dentate at the tip. Perithecia scattered, orbicular, up to $190 \mu \mathrm{m}$ in diam.; ascospores cylindrical to oblong, 4-septate, constricted at the septa, 40-45x17-22 $\mu \mathrm{m}$.

Materials examined: TBGT 5734 (holotype), 8.iii.2010, Kerala, Palghat, Silent Valley, Poochippara, on leaves of Litsea sp. (Lauraceae), P.J. Robin et al. Part of the collection has been deposited in $\mathrm{HClO}$, New Delhi.

Based on the alternate and opposite appressoria and digital formula it is similar to M. dactylipoda Sydow var. brevipoda Hansf. and M. acutisata Sydow known on Cryptocarya patentinervis and Persea piriformis from

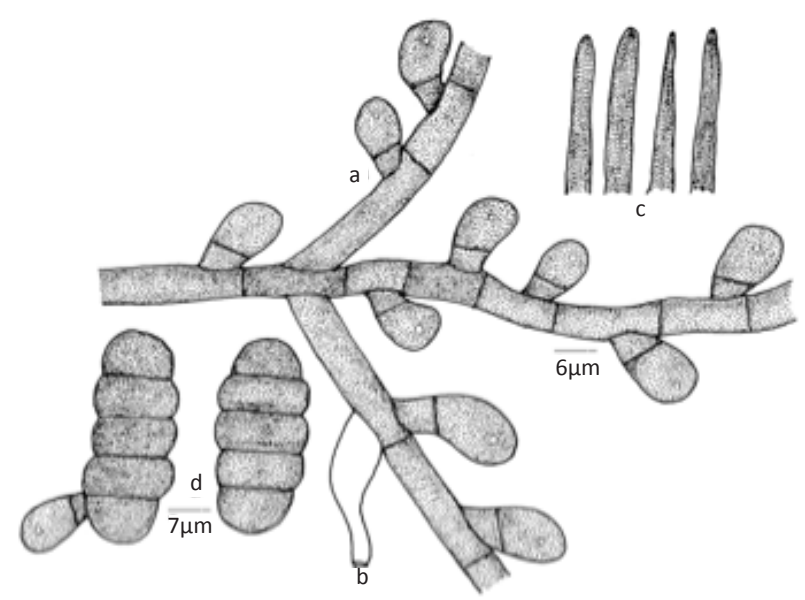

Figure. 77. Meliola ichnocarpi-volubili

a - Appressorium; b - Phialide; c - Apical portion of mycelial setae; d - Ascospores 
New South Wales and Philippines. However, differs from both in having shorter appressoria and globose head cells. This collection is similar to the assigned species but differs from it in having more number of opposite appressoria and smaller ascospores (Hansford 1961).

Meliola kamettiae Hosag. \& Riju, J. Threatened Taxa 2(4): 825, 2010. (Fig. 79)

Colonies hypophyllous, scattered, dense, velvety, up to $4 \mu \mathrm{m}$ in diam., rarely confluent. Hyphae straight to substraight, branching mostly opposite at acute to wide angles, loosely to closely reticulate, cells $13-35 \times 4-7$ $\mu \mathrm{m}$. Appressoria alternate, unilateral, straight, antrorse, 11-20 $\mu \mathrm{m}$ long; stalk cells cylindrical to cuneate, 2-9 $\mu \mathrm{m}$ long; head cells ovate, globose, 7-13×6-11 $\mu \mathrm{m}$. Phialides mixed with appressoria, opposite, alternate, unilateral, ampulliform 11-22x4-7 $\mu \mathrm{m}$. Mycelial setae numerous, up to $260 \mu \mathrm{m}$ long, simple, straight, few slightly curved to uncinate, obtuse, bifid, trifid, often subdentate to furcated to branched at the tip, branches up to $30 \mu \mathrm{m}$ long. Perithecia scattered, up to $150 \mu \mathrm{m}$ in diam.; ascospores cylindrical, 4-septate, slightly constricted at the septa, 26-33x8-11 $\mu \mathrm{m}$.

Materials examined: $\mathrm{HClO} 48175$ (holotype), TBGT 2911 (isotype), 29.ix.2007, on leaves of Kamettia caryophyllata Roxb. (Apocynaceae), 16 $6^{\text {th }}$ mile, Padinharathara,

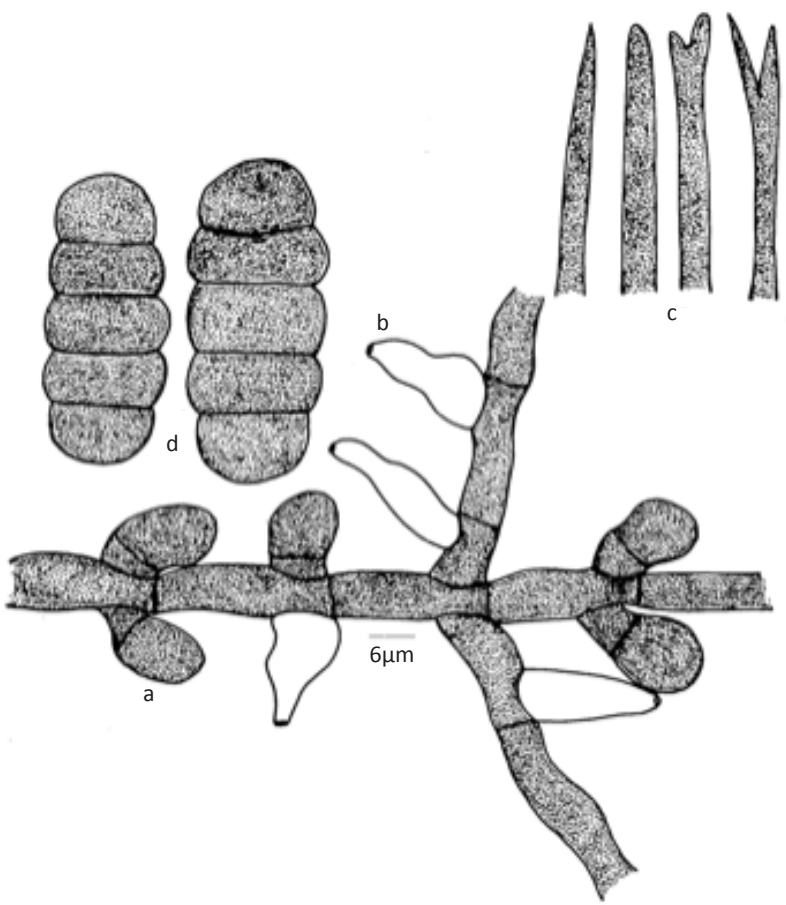

Figure 78. Meliola kakachiana var poochiparensis a - Appressorium; b - Phialide; c - Apical portion of mycelial setae; d - Ascospores
Wayanad, Kerala, M. C. Riju.

Straight, slightly curved to uncinate, obtuse, bifid, trifid, often subdentate to furcated mycelial setae distinguishes this taxon from rest of the Meliola species reported on the members of the family Apocynaceae (Hansford 1961; Hosagoudar 1996, 2008; Hosagoudar et al. 1997).

Meliola kanniyakumariana Hosag. var. brahmagiriense Hosag., Agarwal, H. Biju \& Archana, Indian Phytopath. 59: 347, 2006. (Fig. 80)

Colonies amphigenous rarely hypophyllous, subdense, up to $3 \mathrm{~mm}$ in diameter, confluent. Hyphae sub straight, branching opposite to irregular at acute angles, loosely to closely reticulate, cells $14-24 \times 6-8 \mu \mathrm{m}$. Appressoria alternate to unilateral, antrorse, spreading, straight,14-22 $\mu \mathrm{m}$ long; stalk cells cylindrical to cuneate, 4-8 $\mu \mathrm{m}$ long; head cells globose, ovate, straight, entire, 9-14x8-11 $\mu \mathrm{m}$. Phialides mixed with appressoria, ampulliform, opposite to alternate,12-22x6-10 $\mu \mathrm{m}$. Mycelial setae numerous, simple, straight to slightly curved, acute to obtuse at the tip, up to $216 \mu \mathrm{m}$ long. Perithecia globose, scattered to grouped up to $147 \mu \mathrm{m}$ in diameter; ascospores obovoidal to cylindrical, 4-septate, slightly constricted at the septa, 30-35x11-14 $\mu \mathrm{m}$.

Material examined: HClO 46304 (holotype), TBGT 1950 (isotype), 13.xi.2003, Karnataka, Talakaveri, Brahmagiri, on leaves of Knoxia sp. (Rubiaceae), V.B. Hosagoudar et al.

This taxon is close to $M$. kanniyakumariana reported on Hedyotis sp. from the Western Ghats (Hosagoudar 1996) in having straight to uncinate mycelial setae but

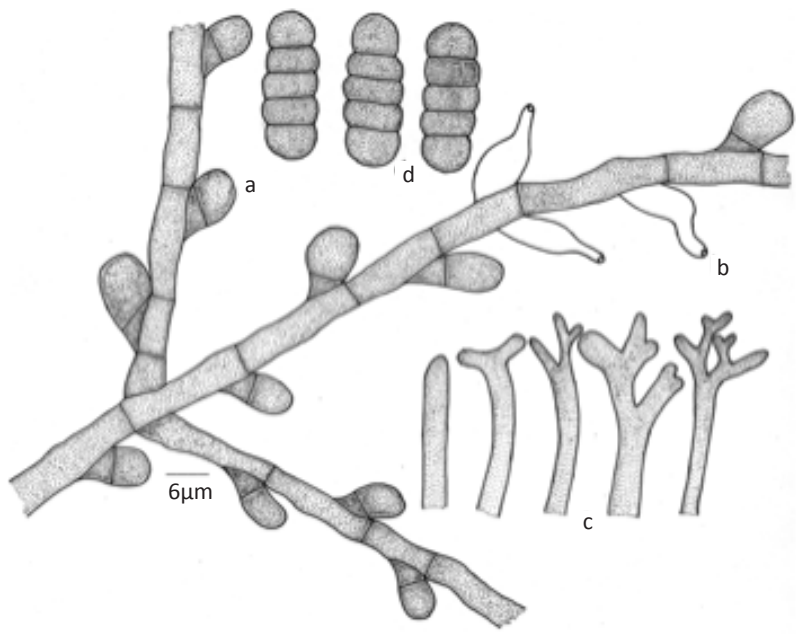

Figure 79. Meliola kamettiae

a - Appressorium; b - Phialide; c - Apical portion of mycelial setae; d - Ascospores 
differs from it in having phialides with appressoria.

Meliola kannurensis Hosag., Archana, Khaleel \& Soumya, Bioscience Discovery 2(3): 348, 2011. (Fig. 81)

Colonies epiphyllous, thin to subdense, up to $5 \mathrm{~mm}$ in diameter, confluent. Hyphae straight, substraight, branching opposite at acute to wide angles, loosely to closely reticulate, cells $16-27 \times 6-10 \mu \mathrm{m}$. Appressoria opposite, alternate, antrorse to subantrorse, 16-23 $\mu \mathrm{m}$ long; stalk cells cylindrical to cuneate, 3-6 $\mu \mathrm{m}$ long; head cells oblong, ovate, entire to slightly angular, 13-17x9$13 \mu \mathrm{m}$. Phialides mixed with appressoria, alternate, opposite, ampulliform, 16-23x9-12 $\mu \mathrm{m}$. Mycelial setae numerous, simple, acute, obtuse to dentate at the tip, up to $882 \mu \mathrm{m}$ long. Perithecia scattered, up to $176 \mu \mathrm{m}$ in diameter; ascospores cylindrical, 4-septate, constricted at the septa, 39-43×13-17 $\mu \mathrm{m}$.

Materials examined: TBGT 4942 (holotype), HClO 51025 (isotype), 21.i.2011, Kerala, Kannur, Payyannur, Edat, on leaves of Ficus gibbosa Bl. (Moraceae), M. Soumya.

Based on the alternate and opposite appressoria, Meliola kannurensis is similar to M. chlorophorae Hansf. reported on Chlorophora excelsa from Uganda but differs from it having both acute, obtuse and dentate and longer mycelial setae (Hansford 1961).

Meliola knemae Hosag. \& Robin, Bioscience Discovery 2(2): 266, 2011. (Fig. 82)

Colonies epiphyllous, thin, up to $4 \mathrm{~mm}$ in diameter, confluent. Hyphae straight to substraight, branching opposite to alternate at acute to wide angles, loosely reticulate, cells $22-29 \times 7-10 \mu \mathrm{m}$. Appressoria alternate to unilateral, antrorse to subantrorse, 19-24 $\mu \mathrm{m}$ long; stalk cells cylindrical to cuneate, 5-10 $\mu \mathrm{m}$ long; head cells ovate to oblong, entire, $14-17 \times 7-10 \mu \mathrm{m}$.

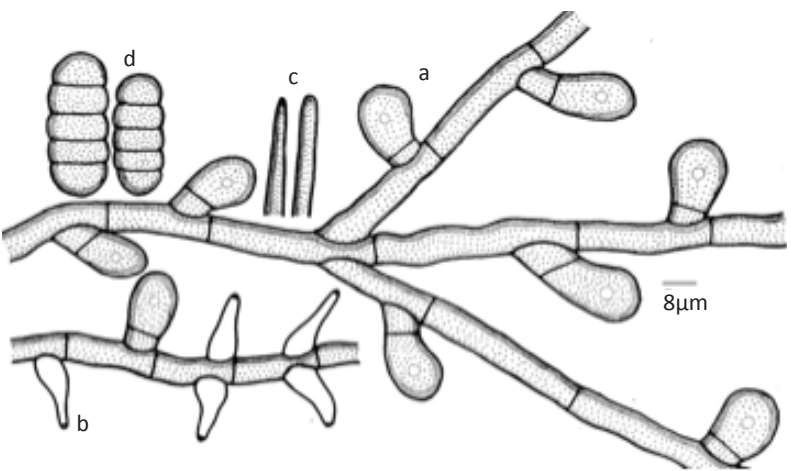

Figure 80. Meliola kanniyakumariana var. brahmagiriense a - Appressorium; b - Phialide; c - Apical portion of mycelial setae; d - Ascospores
Phialides mixed with appressoria, opposite to alternate, ampulliform, 1.7-24x7-10 $\mu \mathrm{m}$. Mycelial setae grouped around perithecia, simple, straight, acute to obtuse at the tip, up to $750 \mu \mathrm{m}$ long. Perithecia scattered, verrucose, up to $173 \mu \mathrm{m}$ in diam.; ascospores ellipsoidal, 4-septate, constricted at the septa, 36-43×14-19 $\mu \mathrm{m}$.

Materialexamined:TBGT4653(holotype), $\mathrm{HClO} 50736$ (isotype), 2.iii.2008, Kerala, Kottayam, Ponthanpuzha reserve forest, on leaves of Knema attenuata (Wall.ex Hook.f.) Thoms. (Myristicaceae), P.J. Robin.

Meliola myristicae Hosag. and Raghu is the only species known on Myristica fatuo Houtl var. mognifico (Bedd.) Sinclair (Myristicaceae) from Gerusoppa, Uttara Kannada, Karnataka (Hosagoudar 1996). However, this species differs from it in having entire, ovate to oblong head cells of appressoria.

Meliola knowltoniae Doidge, Bothalia 1: 308, 1924; Hansf., Sydowia Beih. 2: 62, 1961. (Fig. 83)

Colonies epiphyllous, dense, up to $4 \mathrm{~mm}$ in diameter, confluent. Hyphae substraight to flexuous, branching opposite to irregular at acute to wide angles, loosely to closely reticulate, cells $25-47 \times 5-7 \mu \mathrm{m}$. Appressoria alternate to unilateral antrorse, subantrorse to retrorse 22-32 $\mu \mathrm{m}$ long; stalk cells cylindrical, 7-12 $\mu \mathrm{m}$ long; head cells, ovate, entire, angular to sublobate, 15-20x5$12 \mu \mathrm{m}$. Phialides mixed with appressoria, opposite, ampulliform, 15-25x5-7 $\mu \mathrm{m}$. Mycelial setae scattered,

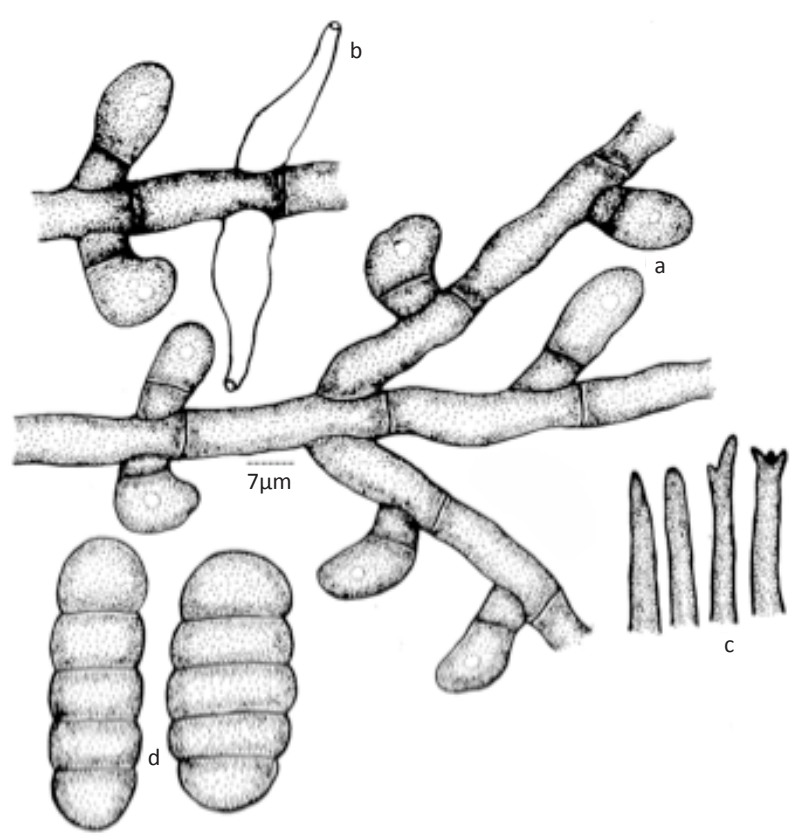

Figure 81. Meliola kannurensis

a - Appressorium; b - Phialide; c - Apical portion of mycelial setae; d - Ascospores 
simple, straight, obtuse at the tip, up to $490 \mu \mathrm{m}$ long. Perithecia scattered orbicular, up to $170 \mu \mathrm{m}$ in diam.; ascospores oblong to cylindrical, 4-septate, constricted at the septa, 37-40x14-18 $\mu \mathrm{m}$.

Materials examined: TBGT 5816, 9.i.2010, on leaves of Clematis sp. (Rananculaceae), Igguthappa temple, Kodagu, Karnataka, C. Jagath Thimmiah.

Meliola kukkeensis Hosag., Archana. \& Agarwal, Hosag., Archana. \& Agarwal, Indian Phytopath. 60: 240, 2007. (Fig. 84)

Colonies amphigenous, sub-dense, up to $2 \mathrm{~mm}$ in diameter, confluent. Hyphae straight to sub-straight, branching opposite, alternate to irregular at acute to wide angles, loosely reticulate, cells $16-40 \times 6-8 \mu \mathrm{m}$. Appressoria alternate, unilateral, antrorse to retrorse, straight to curved, 16-30 $\mu \mathrm{m}$ long; stalk cells cylindrical to cuneate, 6-11 $\mu \mathrm{m}$; head cells oblong, ovate, curved, entire to angular, $10-22 \times 10-16 \mu \mathrm{m}$. Phialides mixed with appressoria, opposite to alternate, unilateral, 1629x6-11 $\mu \mathrm{m}$. Mycelial setae straight, acute, obtuse, dentate to furcate at the tip, very long up to $1196 \mu \mathrm{m}$ long. Perithecia globose, up to $160 \mu \mathrm{m}$ in diameter; ascospores obovoidal, 4-septate, constricted at the septa, 48-53×17-22 $\mu \mathrm{m}$.

Material examined: HClO (holotype), TBGT 2075 (isotype), 15.xi.2003, Karnataka, South Canara, Kukke Subramanya, on leaves of Syzygium sp. (Myrtaceae), V.B. Hosagoudar et al.

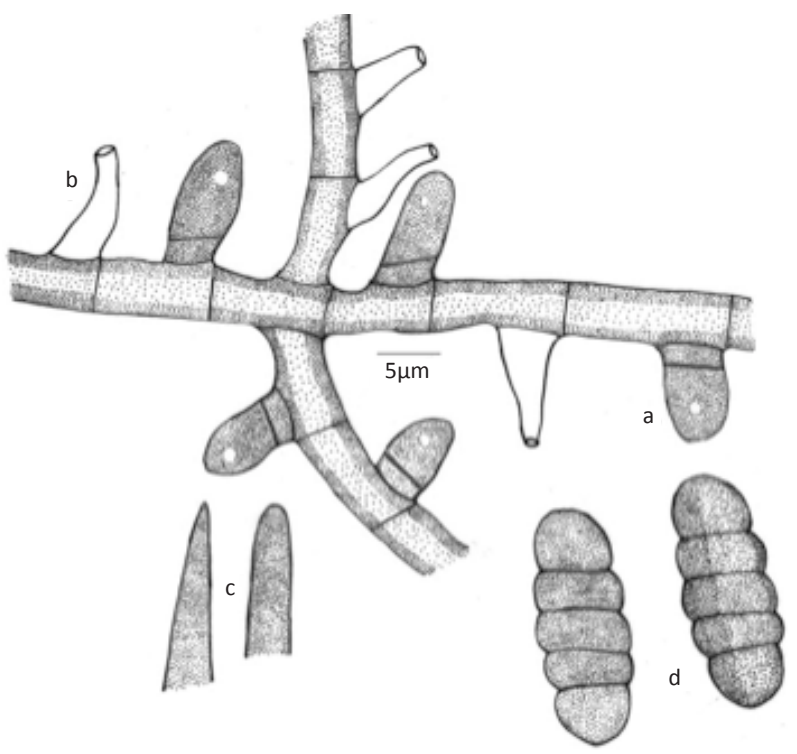

Figure 82. Meliola knemae

a - Appressorium; b - Phialide; c - Apical portion of mycelial setae; d-Ascospores

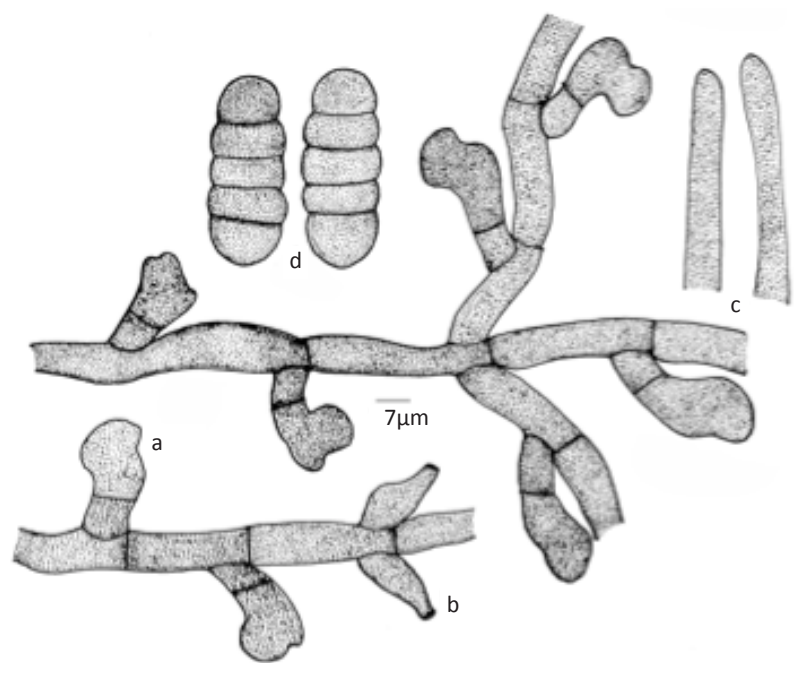

Figure 83. Meliola knowltoniae

a - Appressorium; b - Phialide; c - Apical portion of mycelial setae; d - Ascospores

This species differs from all the known Meliola species on the members of the family Myrtaceae in having simple, dentate to furcate mycelial setae (Hansford 1961; Hosagoudar 1996; Hosagoudar et al. 1997; Hosagoudar \& Abraham 1998).

Meliola lophopetaligena Hosag. \& Robin, J. Threatened Taxa 3(3): 1785, 2011. (Fig. 85)

Colonies epiphyllous, dense, velvety, up to $4 \mathrm{~mm}$ in diameter, confluent. Hyphae straight to substraight, branching mostly opposite at acute angles, loosely to closely reticulate, cells $22-31 \times 7-12 \mu \mathrm{m}$. Appressoria opposite, about 3\% alternate, arranged after an intermittent interval (in most places mycelium devoid of appressoria), closely antrorse, antrorse to subantrorse, 19-26 $\mu \mathrm{m}$ long; stalk cells cylindrical to cuneate, 2-7 $\mu \mathrm{m}$ long; head cells ovate, globose, entire, angular to slightly lobate, $10-14 \times 7-10 \mu \mathrm{m}$. Phialides mixed with appressoria, opposite to alternate, ampulliform, 1926x9-12 $\mu \mathrm{m}$. Mycelial setae numerous, scattered, simple, straight, acute to obtuse at the tip, up to $780 \mu \mathrm{m}$ long. Perithecia scattered, globose, up to $250 \mu \mathrm{m}$ in diameter; ascospores oblong to cylindrical,4-septate,constricted at the septa, 36-46x12-17 $\mu \mathrm{m}$, wall smooth.

Materials examined: HClO 48792 (holotype), TBGT 3168 (isotype), 9.xi.2007, Kerala, Kottayam, Ponthanpuzha, on leaves of Lophopetalum wightiana Arn. (Celastraceae), P.J. Robin.

Meliola lophopetali Stev. ex Hansf. Is known on Lophopetalum toxicum from Philippines. However, Meliola lophopetalilola differs from it in having 


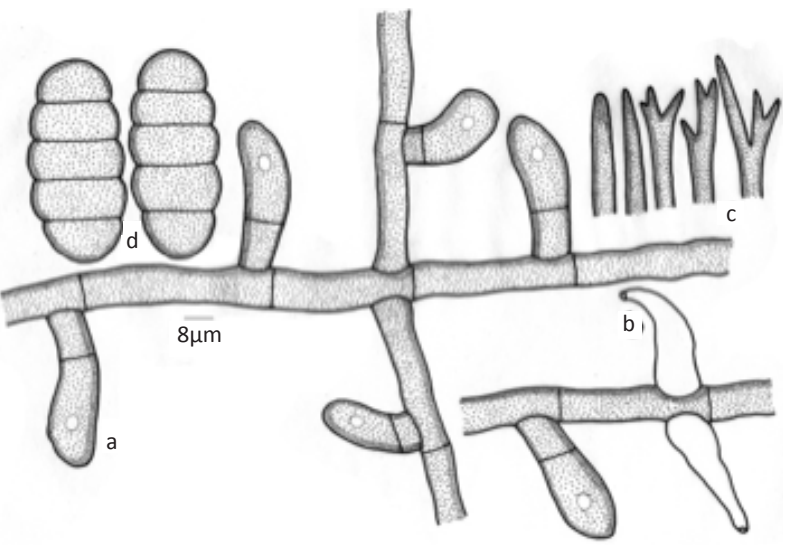

Figure 84. Meliola kukkeensis

a - Appressorium; b - Phialide; c - Apical portion of mycelial setae; d - Ascospores

closely arranged longer appressoria arranged after an intermittent intervals, longer mycelial setae and larger ascospores (Hansford 1961). It also differs from Meliola chennaiana Hosag. \& Goos known on Lophopetalum sp. from Chennai, Eastern Ghats in having 3\% opposite appressoria, ovate, globose, entire, angular to slightly lobate head cells of the appressoria and phialides mixed with appressoria (Goos \& Hosagoudar 1998).

Meliola luculiae Hosag., Dhivaharan \& Riju, J. Sci. Trans. Technov. 4(4): 167, 2011. (Fig. 86)

Colonies amphigenous, thin, scattered, 1-2 mm in diameter. Hyphae flexuous, branching alternate at acute to wide angles, loosely to closely reticulate, cells 22-30x6-7 $\mu \mathrm{m}$. Appressoria alternate, antrorse to subantrorse, straight to curved, 22-25 $\mu \mathrm{m}$ long; stalk cells cylindrical to cuneate, 7-10 $\mu \mathrm{m}$ long; head cells cylindrical, ovate, angular to sublobate, 15-17x10-12 $\mu \mathrm{m}$. Phialides borne on a separate mycelial branch, alternate, opposite to unilateral, ampulliform, 15-17x7$10 \mu \mathrm{m}$. Mycelial setae numerous, grouped around perithecia, simple, straight, obtuse at the tip, up to $300 \mu \mathrm{m}$ long. Perithecia scattered to loosely grouped, up to $190 \mu \mathrm{m}$ in diam.; ascospores cylindrical, 4-septate, constricted at the septa, 42-45×15-17 $\mu \mathrm{m}$.

Materials examined: TBGT 4443 (holotype), HCIO 50526 (isotype), 4.iv.2008, Tamil Nadu, Kukkal shola, Periyakanal, on leaves of Lucculia grandifolia Ghose (Rubiaceae), V. Dhivaharan et al.

Based on the digital formula 3111. 4221, it is closer to Meliola mitragynicola Deight, M. mitragynicola var. leonensis (Hansf. \& Deight.) Deight. and M. henryi Hansf. var. oldenlandiae Hosag. but differs from all in having angular to sublobate head cells of the appressoria and

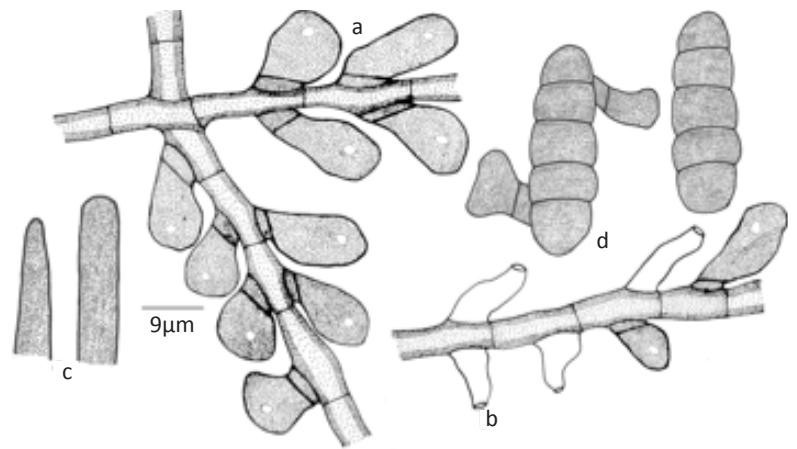

Figure 85. Meliola lophopetaligena

a - Appressorium; b - Phialide; c - Apical portion of mycelial setae; d - Ascospores

shorter mycelial setae (Hansford 1961; Hosagoudar 1996; 2008).

Meliola luvungicola Hosag. \& Rajkumar, Hosag., Archana. \& Agarwal, Indian Phytopath. 60: 241, 2007. (Fig. 87)

Colonies epiphyllous, thin, up to $2 \mathrm{~mm}$ in diameter, confluent. Hyphae straight to substraight, branching opposite at acute to wide angles, loosely to closely reticulate, cells 11-29x6-8 $\mu \mathrm{m}$. Appressoria alternate to unilateral, antrorse, $11-24 \mu \mathrm{m}$; stalk cells cylindrical to cuneate, 3-8 $\mu \mathrm{m}$ long; head cells oblong, sublobate, angular, straight to curved, $8-16 \times 8-14 \mu \mathrm{m}$. Phialides mixed with appressoria, few, opposite, ampulliform, 1116x6-8 $\mu \mathrm{m}$. Mycelial setae scattered, simple, straight, acute at the tip, up to $314 \mu \mathrm{m}$ long. Perithecia scattered, globose, up to $128 \mu \mathrm{m}$ in diameter; ascospores 4-septate, constricted at the septa, 27-30x9-11 $\mu \mathrm{m}$.

Material examined: HCIO 47056 (holotype), TBGT 2273 (isotype), 2.i.2002, Kerala, Thiruvananthapuram, Chemunji, on leaves of Luvunga sp. (Rutaceae), G. Rajkumar.

Meliola luvungae Hosag. is known on this host from Idukki region of the Western Ghats. However, Meliola luvungicola differs from it in having typically lobate head cells of the appressoria and smaller ascospores (Hosagoudar \& Goos 1990; Hosagoudar 1996).

Meliola mahamulkarii Hosag., Robin \& Archana, J. Appl. \& Nat. Sci. 2: 93, 2010. (Fig. 88).

Colonies amphigenous, mostly epiphyllus dense, up to $2 \mathrm{~mm}$ in diameter. Hyphae straight to substright, branching opposite at acute angles, densely reticulate, cells 24-31x5-7 $\mu \mathrm{m}$. Appressoria opposite to alternate, antrorse, 12-17 $\mu \mathrm{m}$ long; stalk cells cylindrical to cuneate, 2-5 $\mu \mathrm{m}$ long; head cells ovate to globose, 
entire, 7-12x5-7 $\mu \mathrm{m}$. Phialides mixed with appressoria, alternate to opposite, ampulliform, 14-19x7-10 $\mu \mathrm{m}$. Mycelial setae scattered, straight, simple, obtuse at the tip, up to $440 \mu \mathrm{m}$ long. Perithecia scattered, up to $178 \mu \mathrm{m}$ in diam.; ascospores obovoidal, 4-septate, constricted at the septa, 43-50x17-19 $\mu \mathrm{m}$.

Materials examined: TBGT 3688 (holotype), HCIO 49443 (isotype), 01.i.2009, Maharashtra, on the way to Mahabeleswar, on leaves of Osyris arborea Wall. (Santalaceae), V.B. Hosagoudar et al.

Meliola osyridicola Hansf. and Meliola osyridicola Hansf. var. indica Hosag. are known on the host genus from the western Ghats of peninsular however Meliola mahamulkarii differs from both having $75 \%$ opposite appressoria.

Meliola manoharacharyi Hosag., Riju \& Agarwal, Indian Phytopath. 63: 76, 2010. (Fig. 89)

Colonies epiphyllous, scattered, thin, up to $2 \mu \mathrm{m}$ diameter, confluent. Hyphae straight to substraight, branching mostly opposite, rarely unilateral at acute to wide angles, loosely reticulate, cells $12-38 \times 6-8$ $\mu \mathrm{m}$. Appressoria opposite (48\%), alternate, unilateral, antrorse to sub antrorse, 15-23 $\mu \mathrm{m}$ long; stalk cells cylindrical to cuneate, 2-8 $\mu \mathrm{m}$ long; head cells globose, ovate, rarely truncate, entire, 7-18x7-13 $\mu \mathrm{m}$. Phialides mixed with appressoria, mostly opposite, often unilateral to alternate, ampulliform, 20-25x7-10 $\mu \mathrm{m}$. Mycelial setae simple, straight to slightly curved,

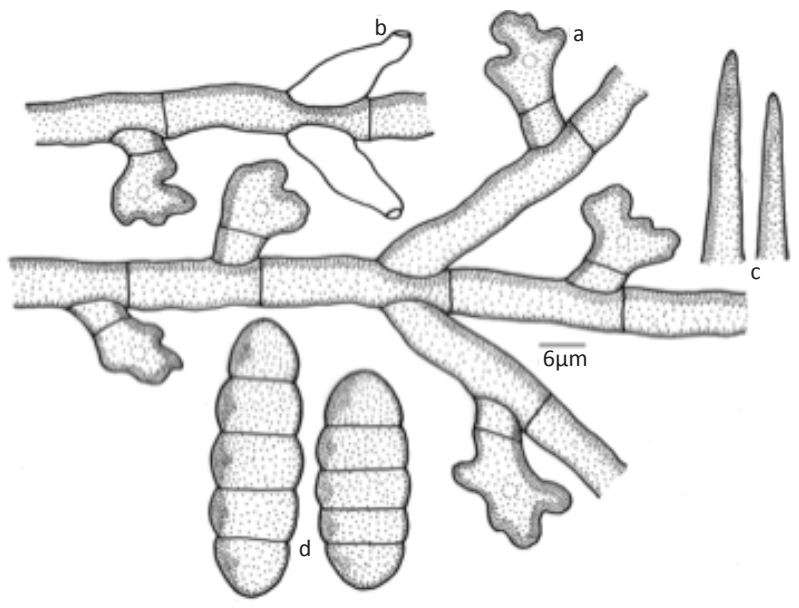

Figure 87. Meliola luvungicola

a - Appressorium; b - Phialide; c - Apical portion of mycelial setae; d - Ascospores

acute to 1-3 times dentate at the tip, up to $1050 \mu \mathrm{m}$ long. Perithecia scattered, varrucose, up to $163 \mu \mathrm{m}$ in diameter; ascospores cylindrical, 4-septate, constricted at the septa, $50-53 \times 20-23 \mu \mathrm{m}$.

Materials examined: HClO 49198 (holotype), TBGT 3437 (isotype), 1.vii.2008, Kerala, Palakkad, Silent Valley National Park, on leaves of Myristica sp. (Myristicaceae), M.C. Riju et al.

Meliola knemicola Hansf., M. uncinata Sydow and $M$. pycnanthi Hansf. are known on the members of the family Myristicaceae (Hansford 1961). Meliola manoharacharyi

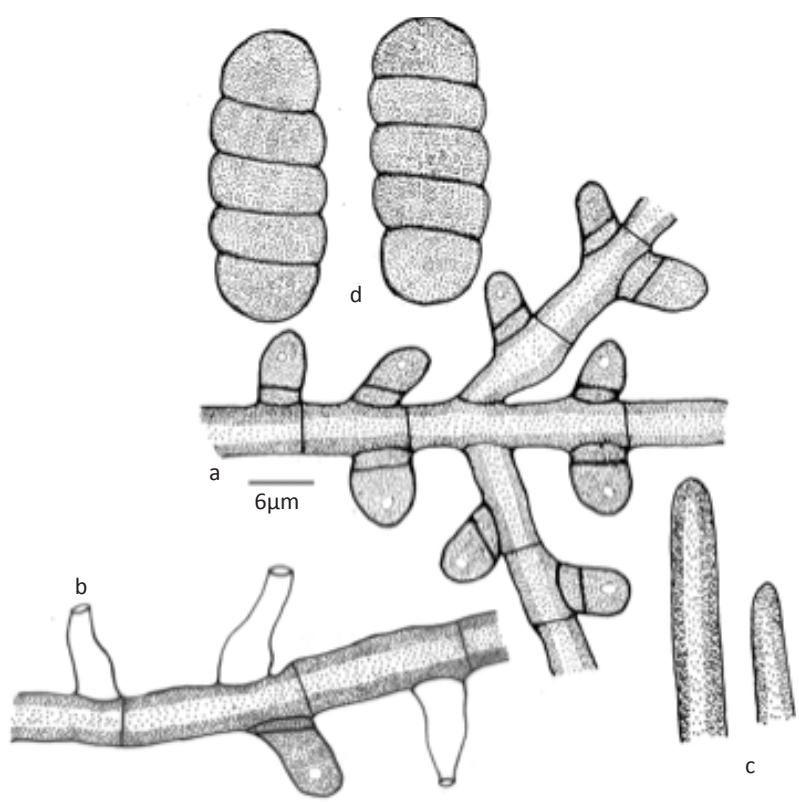

Figure 88. Meliola mahamulkarii

a - Appressorium; b - Phialide; c - Apical portion of mycelial setae; d - Ascospores

a - Appressorium; b - Phialide; c - Apical portion of mycelial setae; d- Ascospores 
differes from the latter two species in having straight mycelial setae and from Meliola knemicola in having opposite appressoria. Meliola knemicola Hansf. var. minor Song \& Ouyang and M. myristicae Hosag. \& Raghu are known from China and the Western Ghats of Peninsular respectively, differ from the present taxon in absence of opposite appressoria and dentate mycelial setae (Hosagoudar 1996; Hosagoudar et al. 1997; Hosagoudar \& Agarwal 2008; Hu et al. 1996, 1999).

Meliola meghalayensis Hosag., Jacob. \& Robin, Indian J. Sci. Technov. 2(6): 3, 2009. (Fig. 90)

Colonies epiphyllous, thin, up to $2 \mathrm{~mm}$ in diameter. Hyphae straight to substraight, branching opposite at wide angles, closely reticulate and form a mycelial net, cells $21-31 \times 7-10 \mu \mathrm{m}$. Appressoria alternate and about $2 \%$ unilateral, straight to curved, antrorse to subantrorse, 24-29 $\mu \mathrm{m}$ long; stalk cells cylindrical to cuneate, 10-12 $\mu \mathrm{m}$ long; head cells subglobose to ellipsoidal, entire to slightly angular, 14-19x12-19 $\mu \mathrm{m}$. Phialides mixed with appressoria, opposite to unilateral, ampulliform, 1726x9-12 $\mu \mathrm{m}$. Mycelial setae grouped around perithecia, simple, straight, acute, obtuse to dentate at the tip, up to $820 \mu \mathrm{m}$ long. Perithecia scattered, globose, verrucose, up to $180 \mu \mathrm{m}$. in diam.; ascospores cylindrical to ellipsoidal, 4-septate, constricted at the septa, 41-43x14-19 $\mu \mathrm{m}$.

Materials examined: $\mathrm{HClO} 48069$ (holotype),

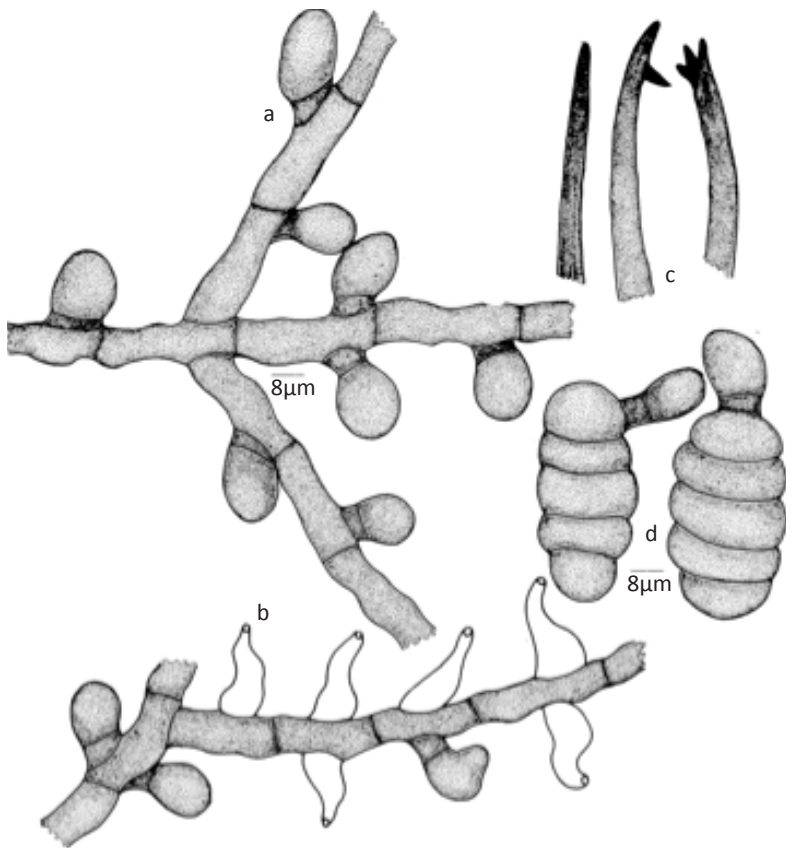

Figure 89. Meliola manoharacharyi

a - Appressorium; b - Phialide; c - Apical portion of mycelial setae; d - Ascospores
TBGT 2852 (isotype), 18.i.2007, Meghalaya, Shillong, Lumshillong, on leaves of Castanopsis armata Spach. (Fagaceae), Jacob Thomas \& P.J. Robin.

This species differs from Meliola taiwanionaYamam. and $M$. melanochaeta Sydow in having simple to dentate mycelial setae. However, it differs from both in having entire head cells of appressoria and smaller ascospores (Hansford 1961). It also differs from M. bosei Hosag. in having longer appressoria, mycelial setae and larger ascospores (Hosagoudar 1996).

Meliola mesuae Hosag., Jacob Thomas \& Agarwal, Nelumbo 52:5, 2010. (Fig. 91)

Colonies amphigenous, mostly epiphyllous, dense, up to $4 \mathrm{~mm}$ in diameter, rarely confluent. Hyphae straight, branching opposite at acute to wide angles, loosely to closely reticulate, cells 15-26x6-9 $\mu \mathrm{m}$. Appressoria alternate, about $2 \%$ opposite, closely arranged, antrorse to subantrorse, straight to curved, 17-29 $\mu \mathrm{m}$ long; stalk cells cylindrical to cuneate, 4-13 $\mu \mathrm{m}$ long; head cells ovate to globose, entire, rarely angular, 11-20x13-18 $\mu \mathrm{m}$. Phialides mixed with appressoria, alternate to opposite, ampulliform, 13-26x6-9 $\mu \mathrm{m}$. Mycelial setae few, straight, simple, acute at the tip, up to $280 \mu \mathrm{m}$ long. Perithecia scattered, verrucose, up to $180 \mu \mathrm{m}$ in diameter; ascospores cylindrical to ellipsoidal, 4-septate, slightly constricted at the septa, 37-42x17-20 $\mu \mathrm{m}$.

Materials examined: HClO 49074 (holotype), TBGT 3329 (isotype), 28.ii.2008, Kerala, Thiruvananthapuram,

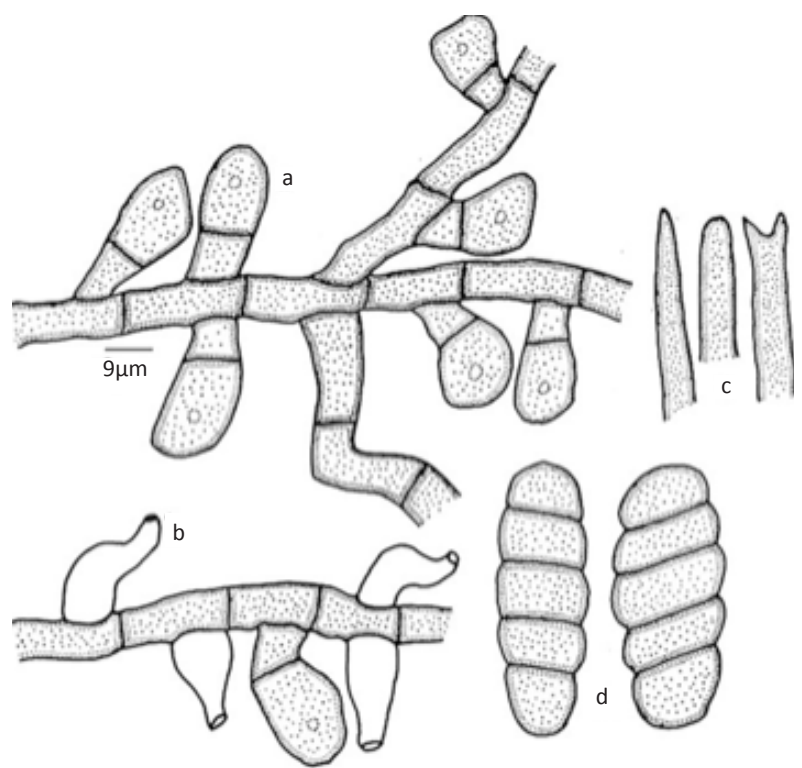

Figure 90. Meliola meghalayensis

a - Appressorium; b - Phialide; c - Apical portion of mycelial setae; d - Ascospores 
Peppara Wildlife Sanctuary, Bonoccord, Kombe, on leaves of Mesua ferrea L. (Clusiaceae), Jacob Thomas.

Based on the angular head cells of the appressoria, this species can be compared with Meliola clusiae Stev. known on Clusia spp. from Porto Rico and Surinam but differs from it in having regularly antrorse appressoria, possessing few mycelial setae and having smaller ascospores (Hansford 1961; Hosagoudar 1996, 2008; Hosagoudar et al. 1997; Hosagoudar \& Agarwal, 2008).

Meliola mutabilidis sp. nov. Hosag., Archana, Khaleel \& Libina

(Fig. 92; MycoBank 803915)

Etymology: Based on the species name of the host plant

Colonies epiphyllous, dense, up to $2 \mathrm{~mm}$ in diameter, scattered. Hyphae substraight to flexuous, branching mostly opposite at acute to wide angles, closely reticulate, cells 12-19x4-6 $\mu \mathrm{m}$. Appressoria alternate, unilateral, antrorse, 9-16 $\mu \mathrm{m}$ long; stalk cells cylindrical to cuneate, 3-6 $\mu \mathrm{m}$ long; head cells globose, ovate, entire to slightly angular, 6-13x6-10 $\mathrm{mm}$. Phialides mixed with appressoria, opposite, ampulliform, 12-28x7-10 $\mu \mathrm{m}$. Mycelial setae numerous, scattered to grouped around perithecia, simple, straight to curved, acute to obtuse at the tip, up to $294 \mu \mathrm{m}$ long. Perithecia scattered to grouped, up to $146 \mu \mathrm{m}$ in diameter; ascospores cylindrical, 4-septate, constricted at the septa, 32-35x11-13 $\mu \mathrm{m}$.

Materials examined: TBGT 4911 (holotype), HClO 50994 (isotype); TBGT 4923, HClO 51006, 21.i.2011, Kerala, Kannur, Mangattuparamba, Neeliyarkottam, on leaves of Hibiscus mutabilis L. (Malvaceae), M.P. Libina.

Irenopsis molleriana (Wint.) Stev. is known on this host from Sierra Leone (Hansford 1961) but differs from it

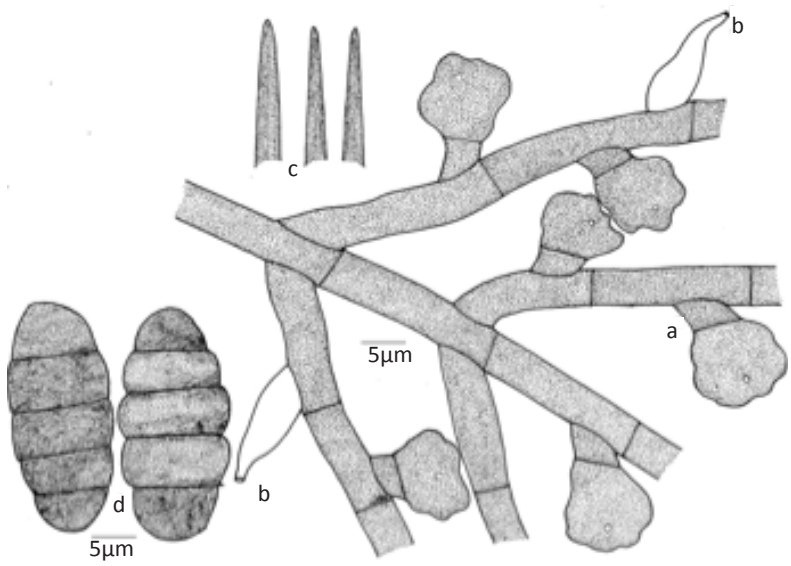

Figure 91. Meliola musuae

a - Appressorium; b - Phialide; c - Apical portion of mycelial setae; d-Ascospores in having mycelial setae. Meliola kydiae-calycinae Hansf. \& Thirum. is the only Meliola species on the members of the family Malvaceae. M. mutabilidis sp. nov. differs from it in having straight hyphae in contrast to crooked, having shorter appressoria 9-16 $\mu \mathrm{m}$ (against 15-24 $\mu \mathrm{m}$ ) and having entire head cells of appressoria in contrast to lobate (Hansford 1961).

Meliola ougeiniae R.K. Verma, N. Sharma \& Soni, Forest fungi of India, p. 47, 2008. (Fig. 93)

Colonies epiphyllous, subdense, up to $3 \mathrm{~mm}$ in diam., confluent. Hyphae substraight, flexuous, branching opposite, alternate at acute to wide angles, closely to loosely reticulate, cells 24-40x4-6.5 $\mu \mathrm{m}$. Appressoria alternate, opposite (20\%), unilateral, straight to curved, antrorse, subantrorse, retrorse, 8-19 $\mu \mathrm{m}$ long; stalk cells cylindrical to cuneate, 1-12 $\mu \mathrm{m}$ long; head cells globose, ovate, oblong, entire to slightly angular, 8-12x8-11 $\mu \mathrm{m}$. Phialides mixed with appressoria, alternate, opposite, unilateral, ampulliform, 11-24x6-8 $\mu \mathrm{m}$. Mycelial setae scattered to grouped around perithecia, simple, straight to slightly curved, acute at the tip, up to $637 \mu \mathrm{m}$ long. Perithecia scattered, up to $175 \mu \mathrm{m}$ in diam.; ascospores cylindrical to obovoidal, 4-septate, constricted at the septa, 38-41x12-16 $\mu \mathrm{m}$.

Materials examined: TF201, $\mathrm{HClO}$ No. 46,449, 18.xii.2004, On leaves of Ougeinia oojeinensis (Roxb.) Hocherut (Fabaceae), Bhaisanghat, Balaghat (M.P.), R.K. Verma, GP $22^{\circ} 08^{\prime} 408^{\prime \prime} 81^{\circ} 05^{\prime} 500^{\prime \prime}$ Tropical Forest Research Institute.

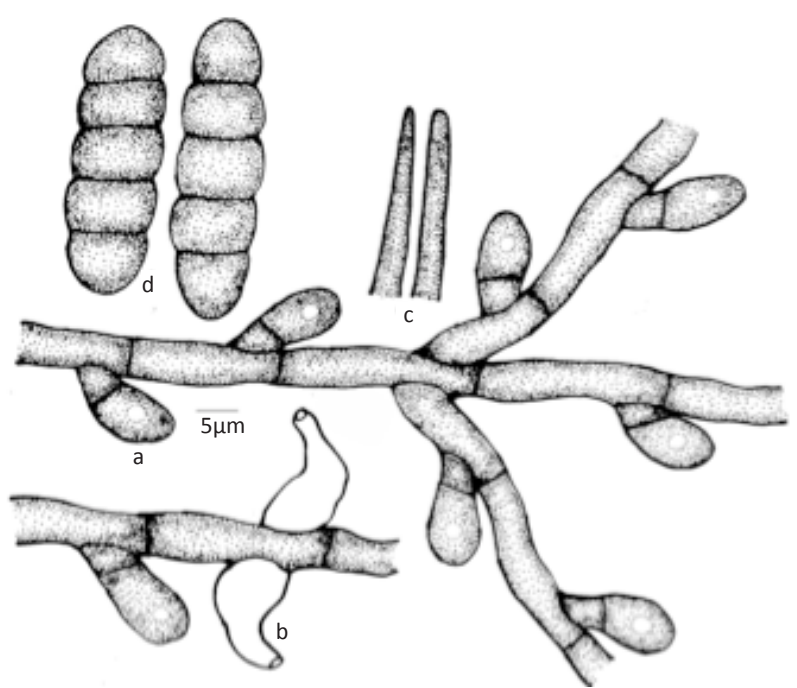

Figure 92. Meliola mutabilidis sp. nov.

a - Appressorium; b - Phialide; c - Apical portion of mycelial setae; d - Ascospores 
Meliola palakkadensis Hosag., Agarwal, H. Biju \& Archana, Indian Phytopathol. 60: 84, 2007. (Fig. 94)

Colonies hypophyllous, sub-dense, velvety, up to $10 \mathrm{~mm}$ in diameter, confluent. Hyphae straight to undulate, branching mostly opposite to irregular at wide angles, loosely reticulate, cells $18-24 \times 6-8 \mu \mathrm{m}$. Appressoria alternate to unilateral, antrorse to subantrorse, straight to curved, 14-24 $\mu \mathrm{m}$ long; stalk cells cylindrical to cuneate, 4-7 $\mu \mathrm{m}$ long; head cells globose, ovate, slightly angular, entire, 9-18x8-13 $\mu \mathrm{m}$. Phialides mixed with appressoria, opposite to unilateral, ampulliform, 13-21x8-10 $\mu \mathrm{m}$. Mycelial setae numerous, scattered, straight, very few uncinate, simple, acute to obtuse at the tip, up to $700 \mu \mathrm{m}$ long. Perithecia globose, scattered, up to $265 \mu \mathrm{m}$ in diameter; ascospores obovoidal, 4-septate, constricted at the septa, 40-48x16-21 $\mu \mathrm{m}$.

Material examined: HClO 46140 (holotype), TBGT 1903 (isotype), 12.12.2003, On leaves of Litsea sp. (Lauraceae), Sairandhiri, Silent Valley, Palakkad, Kerala, V.B. Hosagoudar et al.

Based on the Beeli formula 3111.4333, this species is similar to $M$. pushpangadanii Hosag. \& Abraham (Hosagoudar et al. 1998) but differs from it in having dense colonies, shorter mycelial setae (against $1554 \mu \mathrm{m}$ ) further, many setae are flexuous to uncinate.

Meliola pleurostylicola Hosag. \& Sabu in Hosag., Archana. \& Agarwal. Indian Phytopath. 60: 242, 2007. (Fig. 95)

Colonies mostly epiphyllous, rarely amphigenous, dense to subdense, up to $2 \mathrm{~mm}$ in diameter, confluent.
Hyphae substraight, branching opposite to irregular at acute to wide angles, closely reticulate, cells $12-17 \times 4$ $5 \mu \mathrm{m}$. Appressoria alternate, antrorse, 12-13 $\mu \mathrm{m}$ long; stalk cells cylindrical to cuneate, 5-6 $\mu \mathrm{m}$ long; head cells ovate, globose, entire, straight, 7-8x4-5 $\mu \mathrm{m}$. Phialides mixed with appressoria, opposite to alternate, ampulliform, 12-13x2-4 $\mu \mathrm{m}$. Mycelial setae many, simple, straight, acute to obtuse at the tip, up to 468 $\mu \mathrm{m}$ long. Perithecia scattered, globose, up to $133 \mu \mathrm{m}$ in diameter; ascospores obovoidal, 4-septate, constricted at the septa, 28-31x10-12 $\mu \mathrm{m}$.

Material examined: HClO 47317 (holotype), TBGT 2355 (Isotype), 12.i.2005, Kerala, Thiruvananthapuram, Palode, JNTBGRI Campus, Arboretum, on leaves of Pleurostylia sp. (Celastraceae), T. Sabu.

Asteridiella pleurostyliae (Berk. \& Br.) Hansf. is known on Pleurostylia spp. from South Africa. However, Meliola pleurostylicola differs from it in having mycelial setae. Meliola pleurostylicola differs from Meliola lophopetalii Stev. ex Hansf., M. daliasica Petrak, M. bhesae Hosag. and M. celastracearum Hosag. \& Dayal in having only alternate appressoria (Hansford 1961; Hosagoudar 1996). It also differs from all the Meliola species known on the members of Celastraceae in having 3-septate ascospores, only alternate appressoria and acute to obtuse tip of the mycelial setae (Hansford 1961, Hosagoudar 1996). It differs from M. chennaiana Hosag. \& Goos in having shorter appressoria with entire head cells, phialides mixed with appressoria and smaller ascospores (Goos \& Hosagoudar 1998).

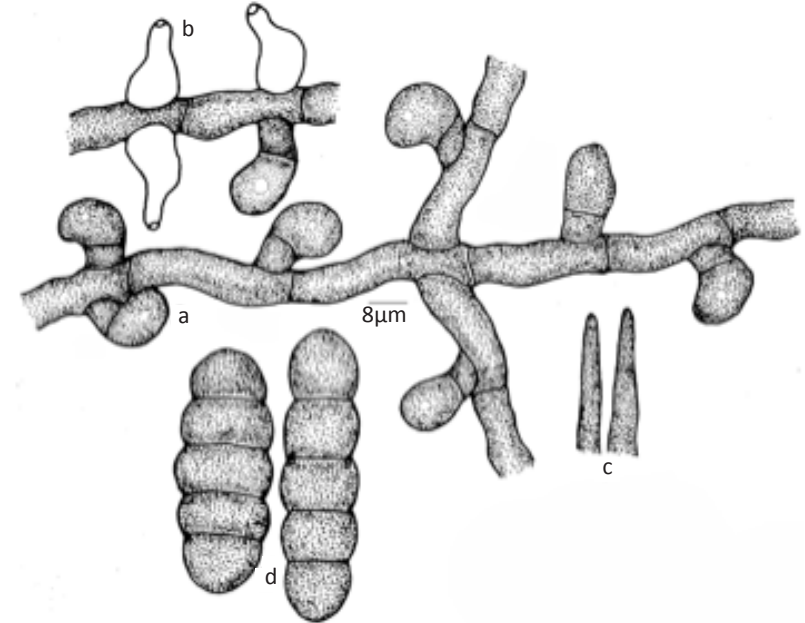

Figure 93. Meliola ougeiniae

a - Appressorium; b - Phialide; c - Apical portion of mycelial setae; d - Ascospores

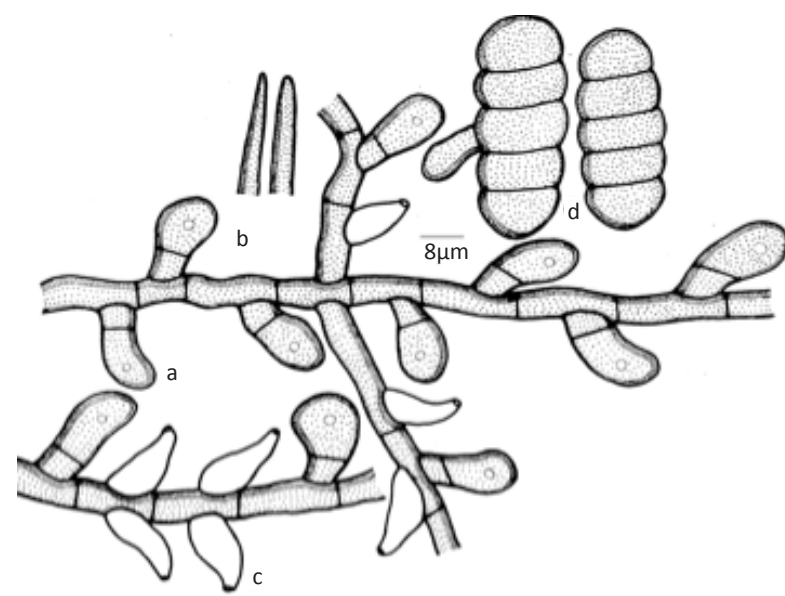

Figure 94. Meliola palakkadensis

a - Appressorium; b - Phialide; c - Apical portion of mycelial setae; d - Ascospores 


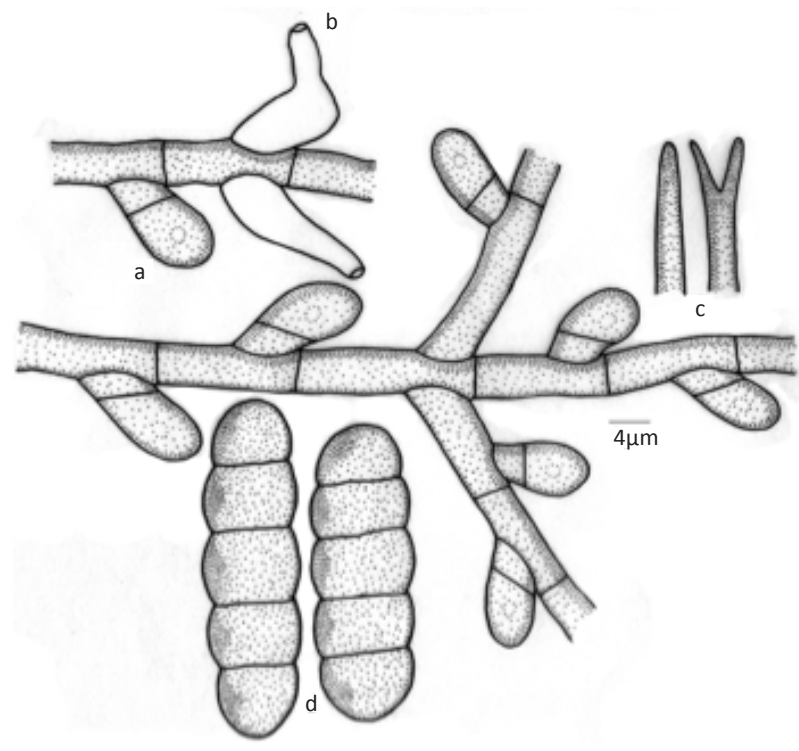

Figure 95. Meliola pleurostylicola

a - Appressorium; b - Phialide; c - Apical portion of mycelial setae; d - Ascospores

Meliola premnigena Hosag. \& Riju, Plant pathology \& Quarantine 1(2): 127, 2011. (Fig. 96)

Colonies epiphyllous, velvety, up to $5 \mathrm{~mm}$ in diam. Hyphae flexuous to crooked, branching opposite at acute to wide angles, cells $15-25 \times 5-8 \mu \mathrm{m}$. Appressoria alternate, unilateral, antrorse to subantrorse, 15-23 $\mu \mathrm{m}$ long; stalk cells cylindrical to cuneate, $5-8 \mu \mathrm{m}$ long; head cells globose, subglobose, entire to sublobate, $10-18 \times$ 7-13 $\mu \mathrm{m}$. Phialides mixed with appressoria, opposite, alternate to unilateral, ampulliform, 14-23×4-6 $\mu \mathrm{m}$. Mycelial setae scattered, simple, straight, slightly curved to uncinate, up to $300 \mu \mathrm{m}$ long. Perithecia scattered, up to $150 \mu \mathrm{m}$ in diam.; ascospores cylindrical to oblong, 4-septate, slightly constricted at the septa, 32-38×12$15 \mu \mathrm{m}$.

Material examined: TBGT 5069 (holotype), 10.i.2011, Kerala, Wayanad, Padinharathara, Banasura mala, on leaves of Premna glaberrima Wight (Verbenaceae), M.C. Riju. Part of the collection has been deposited in $\mathrm{HClO}$, New Delhi.

Based on the alternate appressoria and simple setae, this species comes close to $M$. cookeana Speg. and $M$. premnae Hansf. However, it differs from the former in not having inflated, dentate or furcate apex of mycelial setae. It differs from the latter in having straight hyphae and mycelial setae in contrast to flexuous, crooked, uncinate and twisted mycelia setae (Hansford 1961). It also differs from $M$. premnicola in having only obtuse mycelia setae in contrast to variously dentate ones (Hosagoudar 1996).

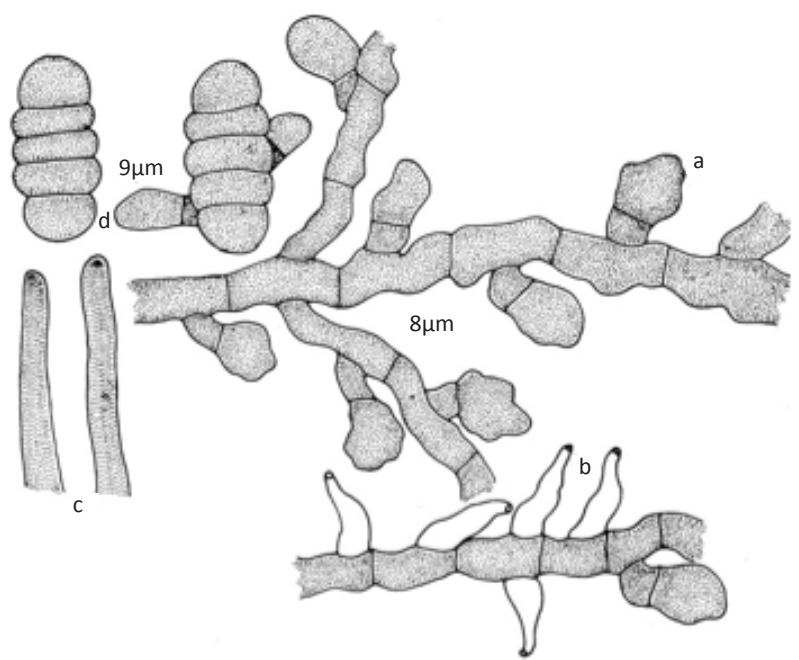

Figure 96. Meliola premnigena

a - Appressorium; b - Phialide; c - Apical portion of mycelial setae; $\mathrm{d}$ - Ascospores

Meliola pseudarthriae var. indica Hosag. \& Jacob Thomas, J. Appl. \& Nat. Sci. 2: 104, 2010. (Fig. 97)

Colonies epiphyllous, dense, velvety, up to $4 \mathrm{~mm}$ in diameter, confluent. Hyphae substraight to undulate, branching opposite atacute to wide angles, closely reticulate, cells 12.8-25.6x6.4-8 $\mu \mathrm{m}$. Appressoria alternate to opposite, antrorse to spreading, straight to curved, 9.6-17.6 $\mu \mathrm{m}$ long;. stalk cells cylindrical to cuneate, 3.2-6.4 $\mu \mathrm{m}$ long; head cells globose to subglobose, ovate, cylindrical, entire, 6.4-14.4x8-14.4 $\mu \mathrm{m}$. Phialides mixed with appressoria, alternate to opposite, ampulliform, 14.4-20.8x6.4-8 $\mu \mathrm{m}$. Mycelial setae, numerous, scattered, simple, straight to slightly curved, acute, dentate to cristate at the tip, up to $600 \mu \mathrm{m}$ long. Perithecia scattered, globose, up to $160 \mu \mathrm{m}$ in diam.; ascospores cylindrical to obovoidal, 4-septate, constricted at the septa, 35.2-40x12.8-16 $\mu \mathrm{m}$.

Material examined: HCIO 49360 (holotype), TBGT 3605 (isotype), 15.iii.2008, Kerala, Thiruvananthapuram, Neyyar Wildlife Sanctuary, near Kombe, on leaves of Pseudarthria viscida (L) Wight \& Arn. (Fabaceae), Jacob Thomas.

This variety differs from var. pseudarthriae in having dentate to cristate mycelia setae.

Meliola psophocarpi Hosag. \& Riju, J. Threatened Taxa 2(4): 826, 2010. (Image. 10, Fig. 98)

Colonies foliicolous, fructicolous, epiphyllous, thin, scattered, up to $3 \mu \mathrm{m}$ in diam., often confluent. Hyphae undulating, branching mostly opposite at wide angles, loosely to closely reticulate, cells $11-33 \times 4-7 \mu \mathrm{m}$. Appressoria alternate, unilateral, up to $3 \%$, opposite, 


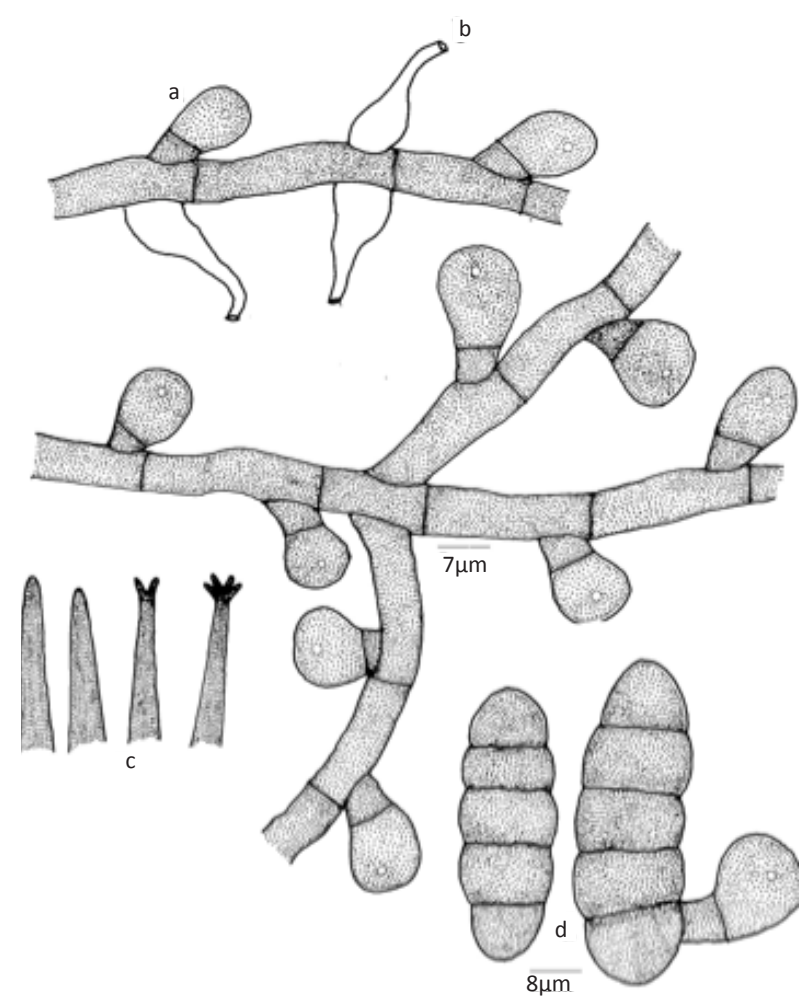

Figure 97. Meliola pseudarthriae var. indica

a - Appressorium; b - Phialide; c - Apical portion of mycelial setae;

$\mathrm{d}$ - Ascospores

straight to slightly curved, subantrorse to retrorse, 11-20 $\mu \mathrm{m}$ long; stalk cells cylindrical to cuneate, 2-11 $\mu \mathrm{m}$ long; head cells ovate, globose, 8-11 $\mu \mathrm{m}$. Phialides mixed with appressoria, alternate, opposite, unilateral, ampulliform, 13-20x6-9 $\mu \mathrm{m}$. Mycelial setae scattered, simple, straight to slightly curved, acute to obtuse, up to $360 \mu \mathrm{m}$ long. Perithecia scattered, up to $130 \mu \mathrm{m}$ in diam., ascospores cylindrical, 4 septate, slightly constricted at the septa, 33-38x8-11 $\mu \mathrm{m}$.

Materials examined: HCIO 48174 (holotype), TBGT 2910 (isotype), 30.ix.2007, on leaves of Psophocarpus tetragonolobus L. (Fabaceae), $16^{\text {th }}$ mile, Padinharathara, Wayanad, Kerala, M.C. Riju.

Psophocarpus tetragonolobus is a climbing shrub, native of South East Asia, has been extensively cultivated in the backyards for its quadrangular pods used in the culinary purposes. The leaves of this plant is being infected with the black mildew fungus and is similar to $M$. nyanzae in having the same digital formula but differs from it in not being a strong parasite in producing pathogenic symptoms (Hansford 1961; Hosagoudar 1996; Hu et al. 1996, 1999).
Meliola pterigotae Hosag., Agarwal, H. Biju \& Archana, Indian Phytopath. 59: 347, 2006. (Fig. 99)

Colonies epiphyllous, dense, velvety, up to $3 \mathrm{~mm}$ in diam., confluent. Hyphae straight to substraight, branching alternate to opposite at acute to wide angles, loosely reticulate, cells $24-32 \times 6-8 \mu \mathrm{m}$. Appressoria alternate, antrorse to subantrorse, 14-23 $\mu \mathrm{m}$ long; stalk cells cylindrical to cuneate, 3-10 $\mu \mathrm{m}$ long; head cells

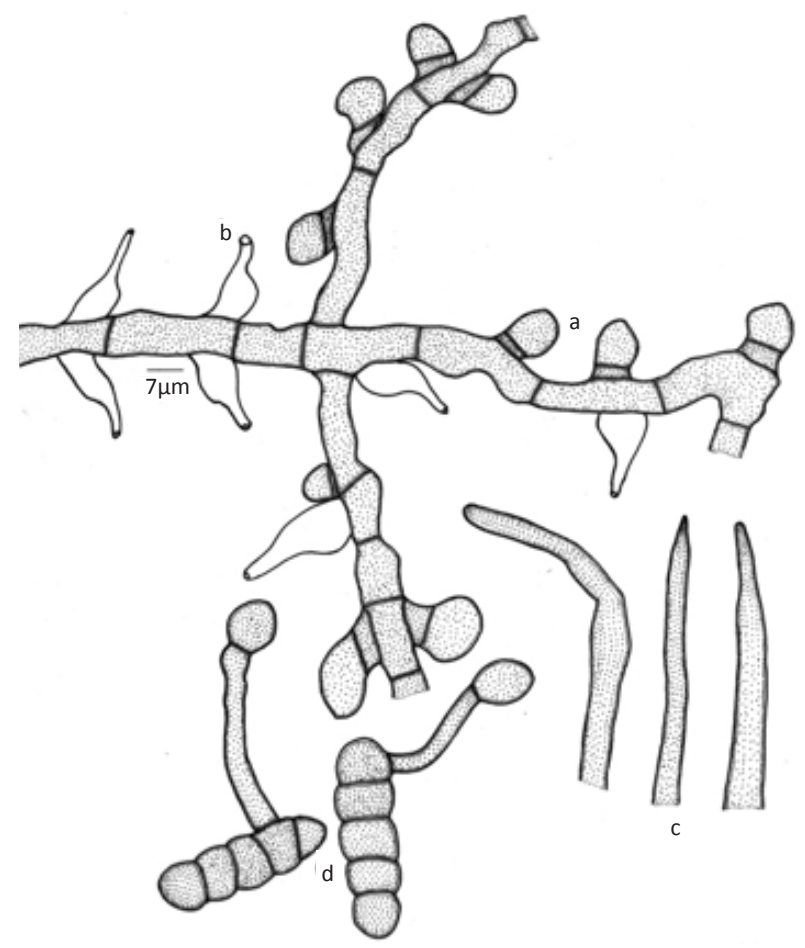

Figure 98. Meliola psophocarpi

a - Appressorium; b - Phialide; c - Apical portion of mycelial setae; d - Ascospores

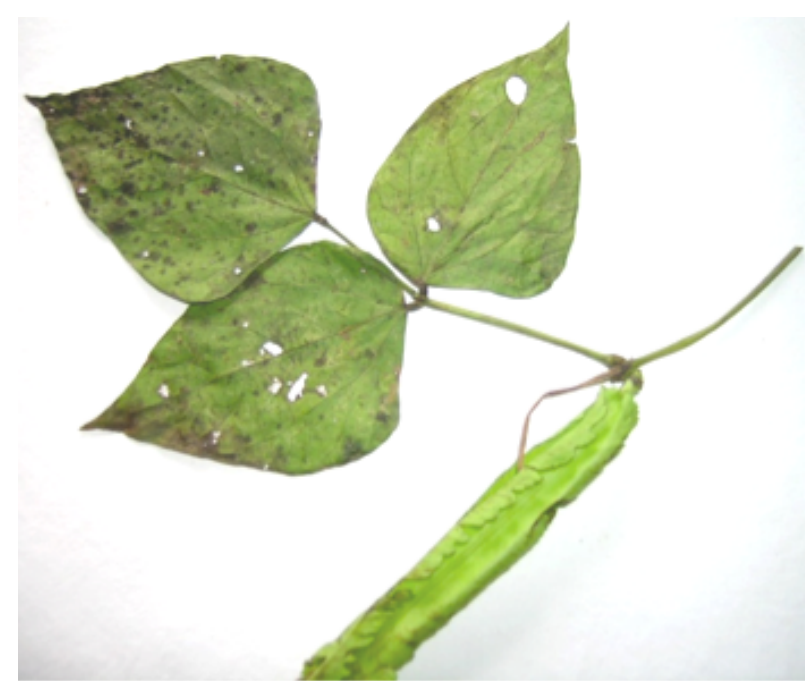

Image 10. Meliola psophocarpi infected leaves 
ovate, globose, oblong, mostly entire, often angular to rarely slightly lobate, $11-15 \times 9-11 \mu \mathrm{m}$. Phialides mixed with appressoria, alternate to opposite, ampulliform, 14-21x8-10 $\mu \mathrm{m}$. Mycelial setae scattered to grouped around perithecia, simple, straight, flexuous to rarely curved, very few uncinate, obtuse at the tip, up to $440 \mu \mathrm{m}$ long. Perithecia scattered to loosely grouped, up to $120 \mu \mathrm{m}$ diam.; ascospores oblong to cylindrical, 4-septate, constricted at the septa, 32-36x11-13 $\mu \mathrm{m}$.

Material examined: HClO 46238 (holotype), TBGT 1650 (isotype), 15.xi.2003, Karnataka, South Canara, Kukke Subramanya, on leaves of Pterygota alata (Roxb.) R. Br. (Sterculiaceae), V.B. Hosagoudar et al.

Based on the Beeli formula 3111.3222 and flexuous mycelial setae, $M$. pterigotae is closer to $M$. pterospermicola Stev. \& Rold. reported on Pterospermum obliquum from Philippines but differs from it in having smaller but dense colonies, shorter appressoria and longer mycelial setae (Hansford 1961; Hosagoudar1996; Hosagoudar et al. 1997).

Meliola pycnosporae Hosag. \& Archana, J. Threatened Taxa 1: 348, 2009. (Fig. 100).

Colonies amphigenous, caulicolous, dense, up to $2 \mathrm{~mm}$ in diam. Hyphae substraight, flexuous to crooked, branching alternate, opposite to irregular at acute to wide angles, loosely to closely reticulate, cells 19-28x6-8 $\mu \mathrm{m}$. Appressoria alternate, about $2 \%$ opposite, antrorse to subantrorse, 11-16 $\mu \mathrm{m}$ long; stalk cells cylindrical to cuneate, 3-5 $\mu \mathrm{m}$ long; head cells ovate, globose, straight to curved, entire, $8-11 \times 7-10 \mu \mathrm{m}$. Phialides mixed with appressoria, alternate to opposite, ampulliform, 19-

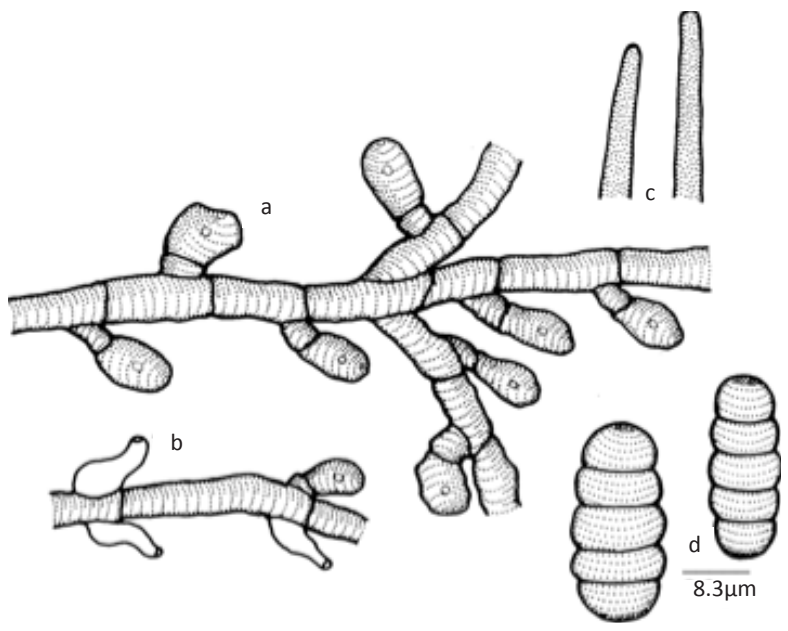

Figure 99. Meliola pterigotae

a - Appressorium; b - Phialide; c - Apical portion of mycelial setae; $\mathrm{d}$ - Ascospores

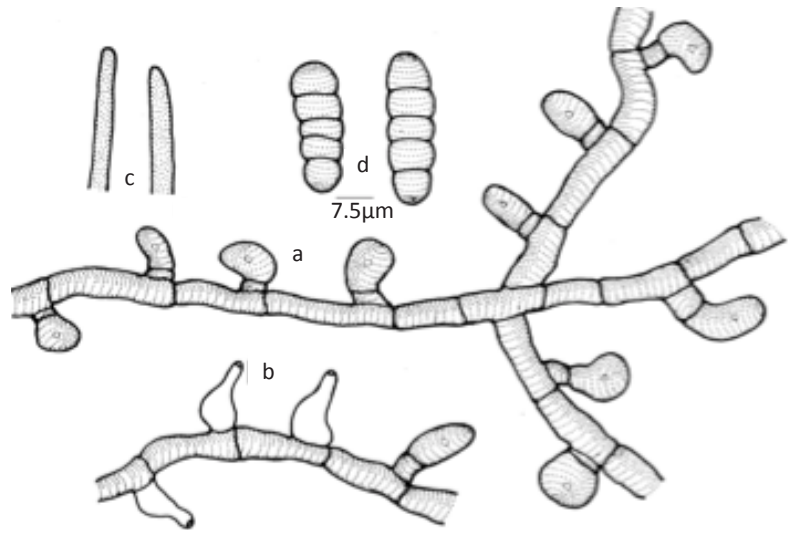

Figure 100. Meliola pycnosporae

a - Appressorium; b - Phialide; c - Apical portion of mycelial setae; d - Ascospores

24x8-10 $\mu \mathrm{m}$. Mycelial setae few, scattered, simple, straight, obtuse at the tip, up to $300 \mu \mathrm{m}$ long. Perithecia scattered, up to $120 \mu \mathrm{m}$ in diam.; ascospores oblong, cylindrical, 4-septate, very slightly constricted at the septa, 30-32x9-11 $\mu \mathrm{m}$.

Material examined: HClO 46244 (holotype), TBGT 1656 (isotype), 14.xii.2003, Kerala, Palghat, Silent Valley, on the way to Chempathy, on leaves of Pycnospora lutescens (Poir.) Schindl. (Fabaceae), V.B. Hosagoudar et al.

Based on the Beeli formula 3113.3221, this species is close to Meliola erythrinae-microptericis Hansf. known on Erythrina micropteryx from San Domingo, but differs from it in having only $2 \%$ opposite appressoria, have straight setae and distinctly narrow ascospores (Hansford 1961).

Meliola rachammae Hosag., Riju \& Agarwal, Indian Phytopath. 63: 77, 2010. (Fig. 101)

Colonies epiphyllous, dense, crustose, up to $5 \mathrm{~mm}$ in diameter, confluent. Hyphae straight, branching opposite at wide angles, loosely to closely reticulate, cells 8-15x6-8 $\mu \mathrm{m}$. Appressoria opposite, antrorse, 16-21 $\mu \mathrm{m}$ long; stalk cells cylindrical to cuneate, 3-7 $\mu \mathrm{m}$ long; head cells globose, ovate, entire, 11-15x8-11 $\mu \mathrm{m}$. Phialides mixed with appressoria, opposite to unilateral, ampulliform, 16-27x7-10 $\mu \mathrm{m}$. Mycelial setae simple, straight to slightly curved, acute to obtuse at the tip, up to $690 \mu \mathrm{m}$ long. Perithecia scattered, globose, up to $185 \mu \mathrm{m}$ in diameter; ascospores cylindrical, 4-septate, constricted at the septa, 50-53×20-23 $\mu \mathrm{m}$.

Material examined: HClO 49199 (holotype), TBGT 3438 (isotype), 30.vii.2008, Kerala, Palakkad, Sailent Valley National Park, Cheriyavalakkad, on leaves of 


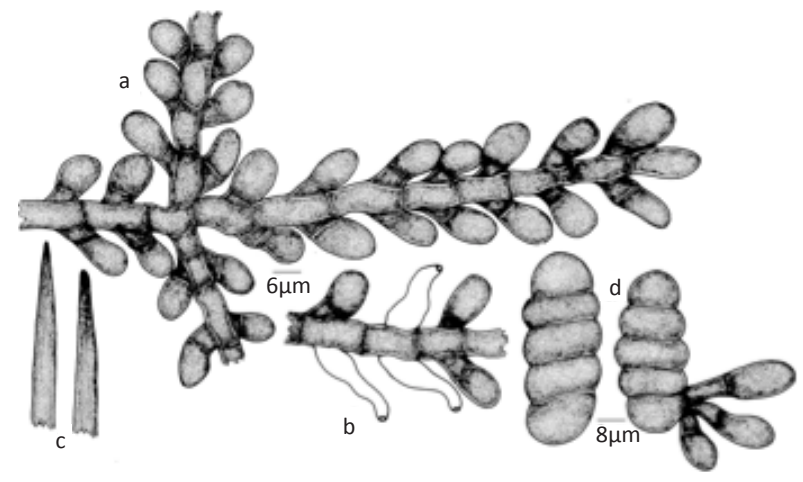

Figure 101. Meliola rachammae

a - Appressorium; b - Phialide; c - Apical portion of mycelial setae; d - Ascospores

Symplocos macrocarpa ssp. kanarana (Talbot) Nooteb. (Symplocaceae), M.C. Riju et al.

There are seven taxa known on the members of the family Symplocaceae (Hansford 1961; Hosagoudar 1996, 2008; Hosagoudar et al. 1997; Hosagoudar and Agarwal, 2008). Of these, the present species can be compared with Meliola bissei in having both alternate and opposite appressoria. However, the present new species differs from all in having regularly opposite appressoria.

Meliola rapaneae Sydow, Ann. Mycol. 26: 87, 1928; Hansf, Sydowia Beih. 2: 510, 1961. (Fig. 102)

Colonies hypophyllous, dense, velvety, up to $5 \mathrm{~mm}$ in diameter, confluent. Hyphae substraight to crooked, branching mostly opposite at acute angles, closely reticulate, cells $16-21 \times 7-10 \mu \mathrm{m}$. Appressoria alternate to opposite, straight to curved, antrorse to spreading, retrorse, $14-22 \mu \mathrm{m}$ long; stalk cells cylindrical to cuneate, 2-5 $\mu \mathrm{m}$ long; head cells ovate, globose to subglobose, cylindrical, clavate, entire, 9-17x9-12 $\mu \mathrm{m}$. Phialides mixed with appressoria, alternate to opposite, ampulliform, 19-26x7-12 $\mu \mathrm{m}$. Mycelial setae fairly numerous, scattered to grouped around perithecia, straight to curved but not uncinate, acute to obtuse at the tip, up to $700 \mu \mathrm{m}$ long. Perithecia scattered to grouped, verrucose, up to $180 \mu \mathrm{m}$ in diam.; ascospores obovoidal, 4-septate, constricted at the septa, 50-55x14-17 $\mu \mathrm{m}$.

Materials examined: $\mathrm{HClO}$ 49035, TBGT 3290, 3.iii.2008, Kerala, Thiruvananthapuram, Neyyar Wildlife Sanctuary, Pongalappara, on leaves of Rapanea sp. (Myrsinaceae), Jacob Thomas et al.

Meliola rapaneae Sydow was known on Rapanea umbellata from British north Borneo and was known only from its holotype locality and the present record reveals it extended distribution.

In the present collection, ascospores were narrower

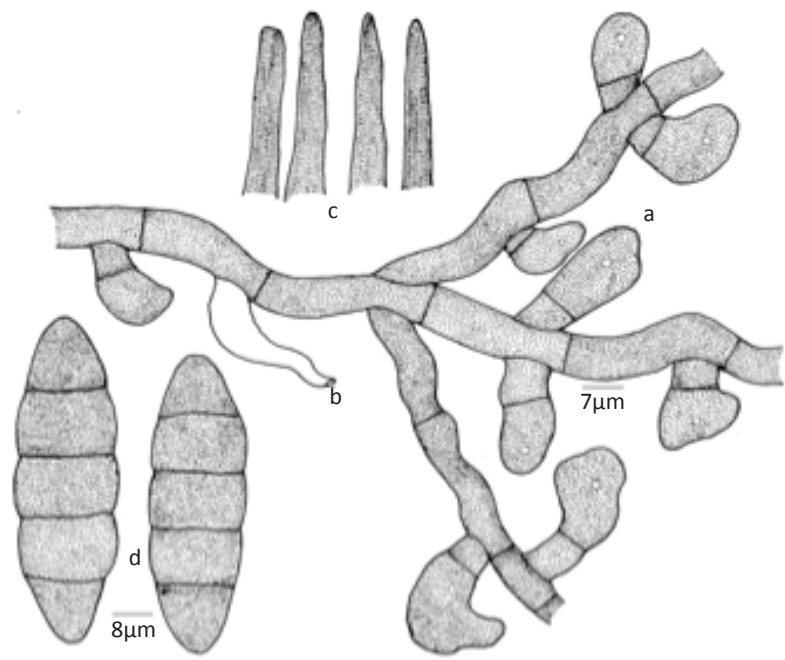

Figure 102. Meliola rapaneae

a - Appressorium; b - Phialide; c - Apical portion of mycelial setae; d - Ascospores

than the holotype.

Meliola sairandhriana Hosag. \& Archana, J. Threatened Taxa 1: 348, 2009. (Fig. 103)

Colonies amphigenous, mostly hypophyllous, dense, velvety, up to $5 \mathrm{~mm}$ in diam. Hyphae straight to substraight, branching alternate to unilateral at acute to wide angles, loosely to closely reticulate, cells 19-32×6$8 \mu \mathrm{m}$. Appressoria opposite, rarely solitary, straight to curved, antrorse, subantrorse to retrorse, 14-18 $\mu \mathrm{m}$ long; stalk cells cylindrical to cuneate, $3-5 \mu \mathrm{m}$ long; head cells ovate, oblong, cylindrical, entire, angular, sublobate to often bilobed, 11-13x8-12 $\mu \mathrm{m}$. Phialides mixed with appressoria, alternate to opposite, ampulliform, 19-23x8-10 $\mu \mathrm{m}$. Mycelial setae many, grouped around perithecia, simple, sigmoid, curved to uncinate at the apical portion, acute, obtuse to bifid at the tip, up to $345 \mu \mathrm{m}$ long. Perithecia loosely grouped, up to $196 \mu \mathrm{m}$ in diam.; ascospores oval, 4-septate, constricted at the septa, 36-40x20-23 $\mu \mathrm{m}$.

Material examined: $\mathrm{HClO} 46139$ (holotype), TBGT 1902 (isotype), 13.xii.2003, Kerala, Palghat, Silent Valley, Sairandhri, on leaves of Aglaia minutiflora Bedd. (Meliaceae), V.B. Hosagoudar et al.

Based on the uncinate mycelial setae, $M$. sairandhriana can be compared to $M$. reinwardtiodendri Hosag. known on Reinwardtiodendron anamallayanam from the Western Ghats region but differs from it in having amphigenous colonies, simple to dentate mycelial setae and smaller ascospores (Hosagoudar 1996). 


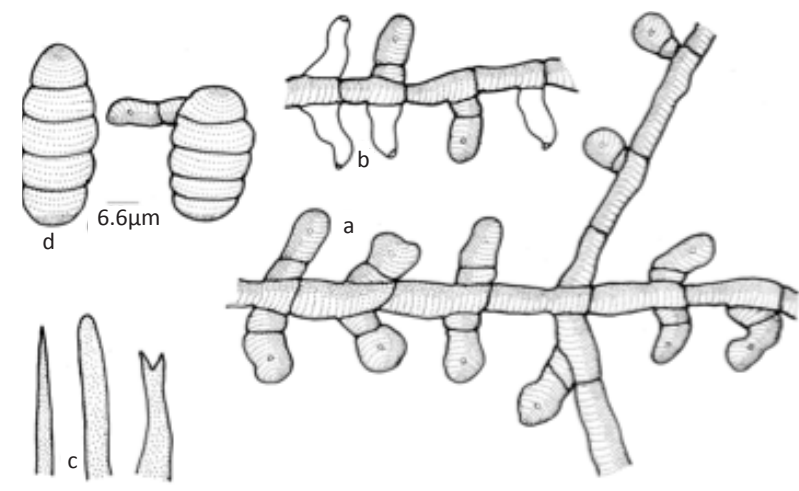

Figure 103. Meliola sairandhriana

a - Appressorium; b - Phialide; c - Apical portion of mycelial setae; d-Ascospores

Meliola salaciicola Hosag., Agarwal, H. Biju \& Archana, Indian Phytopathol. 60: 85, 2007. (Fig. 104)

Colonies amphigenous, subdense, up to $2 \mathrm{~mm}$ in diameter. Hyphae straight to sub straight, branching mostly opposite to irregular at acute to wide angles, loosely to closely reticulate, cells 14-29x6-8 $\mu \mathrm{m}$. Appressoria mostly alternate, up to $1 \%$ opposite, unilateral , antrorse to sub-antrorse, straight to slightly curved, 12-19 $\mu \mathrm{m}$ long; stalk cells cylindrical to cuneate, 3-6 $\mu \mathrm{m}$ long; head cells globose, ovate, oblong, entire to slightly angular, straight, 8-16x6-10 $\mu \mathrm{m}$. Phialides mixed with appressoria, ampulliform, opposite, alternate to unilateral, 12-24x6-11 $\mu \mathrm{m}$. Mycelial setae numerous, simple, straight, curved to arcuate, acute to obtuse at the tip, up to $510 \mu \mathrm{m}$ long. Perithecia globose, grouped, up to $245 \mu \mathrm{m}$ in diameter; ascospores obovoidal, 4-septate, slightly constricted at the septa, 40-48x16-18 $\mu \mathrm{m}$.

Material examined: HClO 46307 (holotype), TBGT 1953 (isotype), 13.xii.2003, Kerala, Palakkad, Silent Valley, Sairandhiri, on leaves of Salacia sp. (Hippocrataceae), V.B. Hosagoudar et al.

This species differs from all the Meliola species known on the members of the host family Hippocrataceae in having curved to arcuate mycelial setae (Hansford 1961; Hosagoudar 1996; Hosagoudar et al. 1997).

Meliola sanjappae Hosag., Jacob Thomas \& Agarwal, Nelumbo 52: 7, 2010. (Fig. 105)

Colonies epiphyllous, dense, velvety, up to $4 \mathrm{~mm}$ in diameter, scattered. Hyphae straight, branching opposite at wide angles, closely reticulate and form a mycelial net, cells $17-35 \times 10-13 \mu \mathrm{m}$. Appressoria alternate, up to $5 \%$ opposite, antrorse to retrorse, straight to curved, 20-24 $\mu \mathrm{m}$ long; stalk cells cylindrical to cuneate, 4-10 $\mu \mathrm{m}$ long; head cells cylindrical to clavate, curved, entire,

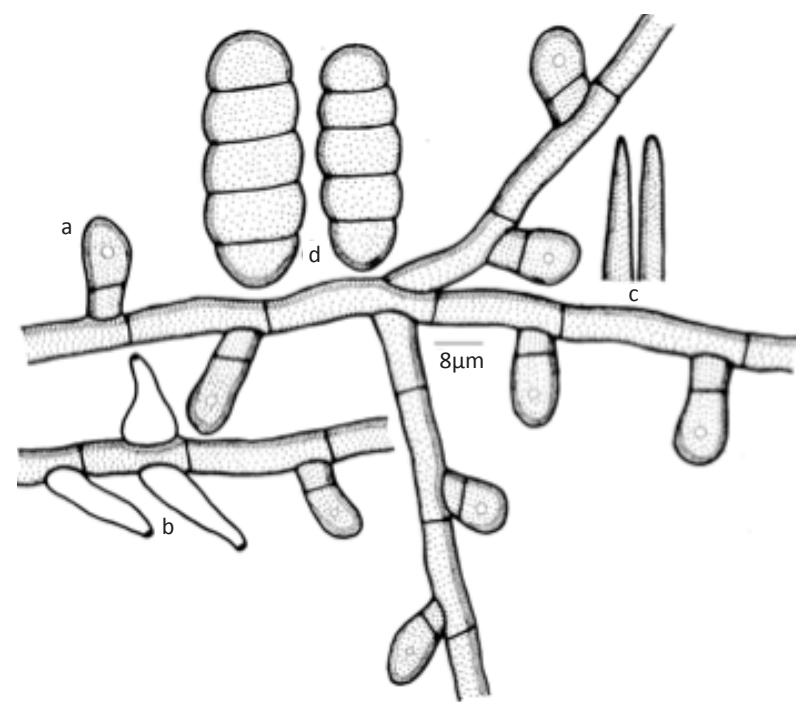

Figure 104. Meliola salaciicola

a - Appressorium; b - Phialide; c - Apical portion of mycelial setae; d - Ascospores

truncate, angular to rarely sublobate, 16-22x9-16 $\mu \mathrm{m}$. Phialides mixed with appressoria, alternate to opposite, ampulliform, 11-16x8-11 $\mu \mathrm{m}$. Mycelial setae scattered, fairly numerous, simple, straight, dichotomously branched, up to $250 \mu \mathrm{m}$ long up to first branching, first ray up to $70 \mu \mathrm{m}$ long, second ray up to $5 \mu \mathrm{m}$ long, acute to dentate at the tip, branches reflexed. Perithecia scattered, verrucose, up to $180 \mu \mathrm{m}$ in diameter; ascospores obovoidal to subellipsoidal, 4-septate, constricted at the septa, 44-50×20-23 $\mu \mathrm{m}$.

Materials examined: HCIO 49043 (holotype), TBGT 3298 (isotype), 5.iii.2008, Kerala, Thiruvananthapuram, Neyyar Wildlife Sanctuary, Kombe, on leaves of Semecarpus travancorica Bedd. (Anacardiaceae), Jacob Thomas.

Meliola tapiriae Stev. \& Tehon and M.brachydenta Sydow var. dammeri Hansf. are the two taxa reported on Tapiria sp. and Rhus villosa from British Guiana and Uganda having dichotomously branched mycelial setae. However, the new species differs from both in having alternate and opposite appressoria and differ in ascospore measurements (Hansford 1961; Hosagoudar 1996; Hosagoudar et al. 1997; Hosagoudar \& Agarwal, 2008).

Meliola shillongensis Hosag., Jacob. \& Robin, Indian J. Sci. Technol. 2 (6): 4, 2009. (Fig. 106)

Colonies epiphyllous, dense, velvety, up to $3 \mathrm{~mm}$ in diameter. Hyphae substraight to undulate, branching alternate to opposite at acute to wide angles, closely reticulate and form a mycelial mat at the centre, cells 


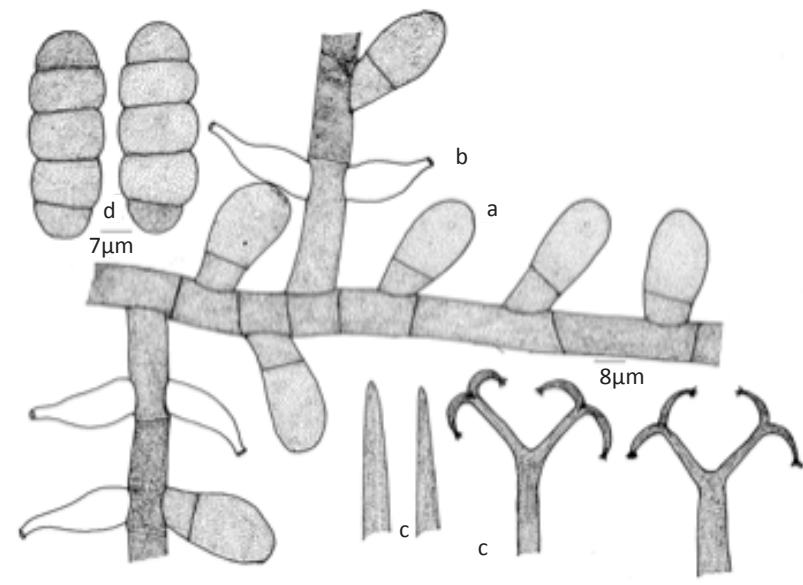

Figure 105. Meliola sanjappae

a - Appressorium; b - Phialide; c - Apical portion of mycelial setae; $d$ - Ascospores

19-25x7-9 $\mu \mathrm{m}$. Appressoria alternate, antrorse to retrorse, straight to curved, closely placed, 22-34 $\mu \mathrm{m}$ long; stalk cells cylindrical to cuneate, 7-12 $\mu \mathrm{m}$ long; head cells ovate, globose to subglobose, entire, 1422x9-12 $\mu \mathrm{m}$. Phialides few in number, mixed with appressoria, opposite, ampulliform, 21-29x7-10 $\mu \mathrm{m}$. Mycelial setae numerous, grouped around perithecia, simple, straight, slightly curved, acute to obtuse at the tip, up to $620 \mu \mathrm{m}$ long. Perithecia scattered, globose, verrucose, up to $170 \mu \mathrm{m}$ in diam.; ascospores oblong to obovoidal, cylindrical, 4-septate, constricted at the septa, 19-31x10-12 $\mu \mathrm{m}$.

Materials examined: HClO 48065 (holotype), TBGT 2848 (isotype), 21.i.2007, Meghalaya, Shillong, Mawphlang, on the leaves of Vaccinium griffithianum Wight (Vacciniaceae), Jacob Thomas \& P.J. Robin.

Based on the morphology and measurements, $M$. shillongensis closer to $M$. vaccinii Stev. known on Vaccinium reticulatum from Hawaii (Hansford 1961; Hosagoudar et al. 1997). However, differs from it in having only alternate and shorter appressoria and smaller ascospores.

Meliola sterculicola Hosag. \& Robin, J. Threatened Taxa 3(5): 1782, 2011. (Fig. 107)

Colonies epiphyllous, thin, up to $3 \mathrm{~mm}$ in diameter, confluent. Hyphae straight to substraight, branching mostly opposite at wide angles, loosely to closely reticulate, cells $19-26 \times 4-7 \mu \mathrm{m}$. Appressoria mostly alternate, unilateral, antrorse to subantrorse, 21-26 $\mu \mathrm{m}$ long; stalk cells cylindrical to cuneate, 5-10 $\mu \mathrm{m}$ long; head cells ovate, globose, entire, angular to slightly lobate, 19-14x10-12 $\mu \mathrm{m}$. Phialides borne on a separate

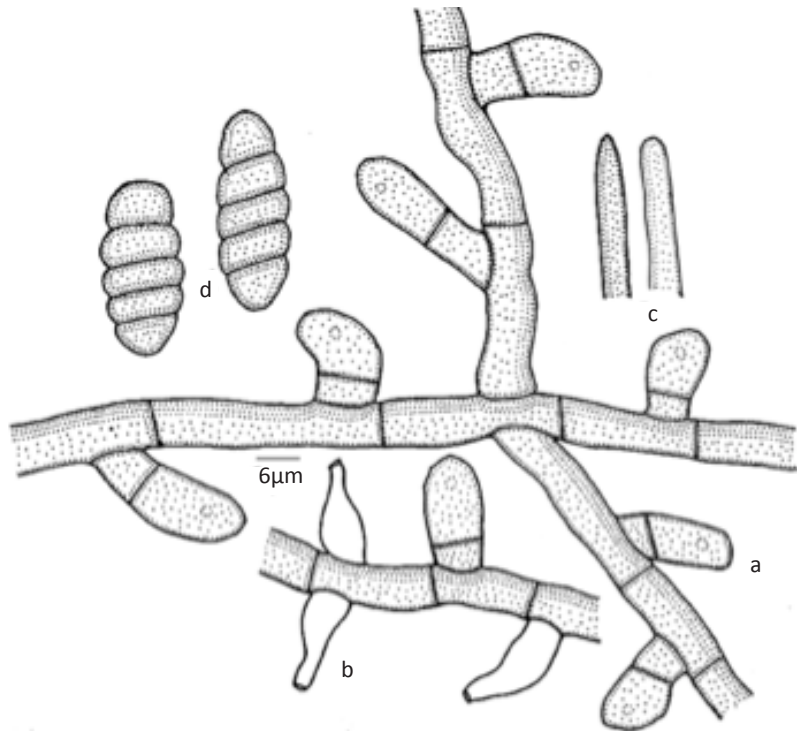

Figure 106. Meliola shillongensis

a - Appressorium; b - Phialide; c - Apical portion of mycelial setae; d - Ascospores

mycelia branch, opposite, alternate to unilateral, ampulliform, 14-24x5-7 $\mu \mathrm{m}$. Mycelial setae few, simple, straight, acute at the tip, up to $480 \mu \mathrm{m}$ long. Perithecia scattered, globose, up to $110 \mu \mathrm{m}$ in diameter; ascospores oblong, ellipsoidal, 4-septate, constricted at the septa, 34-41x14-17 $\mu \mathrm{m}$.

Materials examined: HCIO 48143 (holotype), TBGT 2879 (isotype), 22.xii.2006, Kerala, Kottayam, Placherry, Ponthanpuzha, on leaves of Sterculia sp. (Sterculiaceae), P.J. Robin \& M. Harish.

Based on the digital formula 3111.3222, it can be compared with Meliola sterculiacearum Hosag. \& Kamar. known on the same host genus from Wayanad in Western

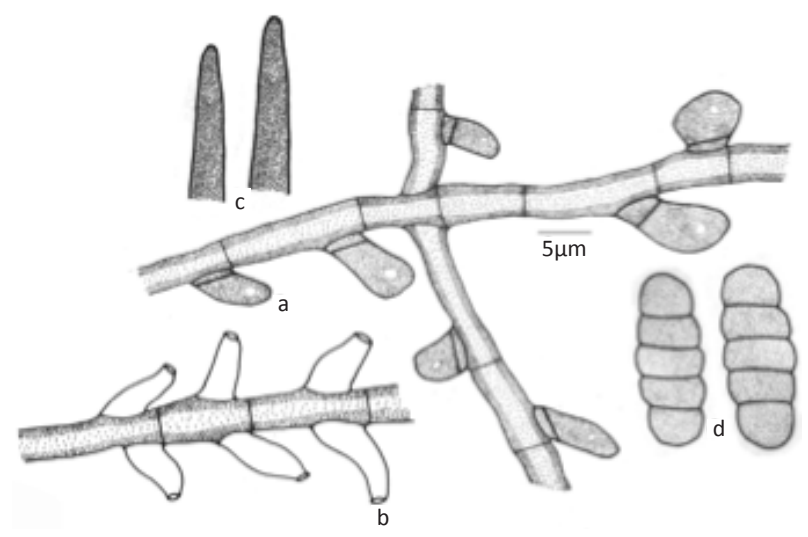

Figure 107. Meliola sterculicola

a - Appressorium; b - Phialide; c - Apical portion of mycelial setae; d - Ascospores 
Ghats. However, the present new species differs from it in having longer appressoria with angular to sublobate head cells and phialides borne on a separate mycelia branch (Hosagoudar 2005).

Meliola strebli Hosag. \& Archana, J. Threatened Taxa 1: 349, 2009. (Fig. 108)

Colonies amphigenous, mostly hypophyllous, dense, velvety, up to $3 \mathrm{~mm}$ diam., confluent. Hyphae straight to substraight, branching alternate to opposite at acute to wide angles, loosely to closely reticulate, cells $20-24 \times 6-8$ $\mu \mathrm{m}$. Appressoria alternate to unilateral, distantly placed, antrorse, subantrorse to rarely retrorse, 17-21 $\mu \mathrm{m}$ long; stalk cells cylindrical to cuneate, 4-6 $4 \mathrm{~m}$ long; head cells ovate, globose, entire, straight to curved, 11-15x9-11 $\mu \mathrm{m}$. Phialides mixed with appressoria, alternate to opposite, ampulliform, 16-19x8-10 $\mu \mathrm{m}$. Mycelial setae scattered, simple, straight, acute at the tip, up to $735 \mu \mathrm{m}$ long. Perithecia scattered to loosely grouped, up to $212 \mu \mathrm{m}$ diam.; ascospores oblong, 4-septate, slightly constricted at the septa, 40-44×16-18 $\mu \mathrm{m}$.

Material examined: $\mathrm{HClO} 46162$ (holotype), TBGT 1574 (isotype); TBGT 1605, HClO 46193, 24.xi.2004, Kerala, Kollam, Sankili forest, Shendhurney Wildlife Sanctuary, near Sasthanada tribal colony, on leaves of Streblus taxoides (Heyne ex Roth) Kurz (Moraceae), V.B. Hosagoudar et al.; TBGT 1889, HCIO 46126, Kollam, Shendhurney Wildlife Sanctuary, Sankili forest, on leaves of S. asper Lour., V.B. Hosagoudar et al.; TBGT 1893, $\mathrm{HClO} 46130$, Tribal colony, Sasthanamada, on leaves of Streblus sp., V.B. Hosagoudar et al.

Based on the digital formula 3111.4233, this species can be compared with Meliola ficium Yates and its variety var. ugandensis Hansf. However, M. strebli differs from $M$. ficium in having narrow ascospores and having longer mycelial setae (3111.4333). It also differs from M. ficium Yates var. ugandensis Hansf. in having shorter appressoria and larger ascospores (Hansford 1961).

Meliola strombosiicola nom. nov. Meliola strombosiae Hosag., Agarwal, H. Biju \& Archana, Indian Phytopath. 59: 348, 2006 (non Ciferri, 1954).

(Fig. 109; MycoBank 803917)

Colonies epiphyllous, dense, up to $1 \mathrm{~mm}$ in diam. Hyphae straight, substraight to flexuous, branching alternate to opposite at acute to wide angles, loosely to closely reticulate, cells $16-20 \times 6-8 \mu \mathrm{m}$. Appressoria alternate, antrorse, 20-32 $\mu \mathrm{m}$ long; stalk cells cylindrical to cuneate, 4-10 $\mu \mathrm{m}$ long; head cells ovate, oblong, entire, broadly rounded to truncate to attenuated at the apex, 16-24x6-8 $\mu \mathrm{m}$. Mycelial setae scattered, simple, straight, acute at the tip, up to $650 \mu \mathrm{m}$ long. Perithecia scattered, up to $120 \mu \mathrm{m}$ in diam.; ascospores cylindrical to ellipsoidal, 4-septate, constricted at the septa, 3640x15-17 $\mu \mathrm{m}$.

Materials examined: HClO 45972 (Holotype), TBGT 1736 (Isotype), 15.xi.2003, Karnataka, South Canara, Kukke Subramanya, on leaves of Strombosia ceylanica Garden. (Olacaceae), V.B. Hosagoudar et al.

Etymology: Based on the host genus

Hansford (1946) proposed Irenina strombosiae on Strombosia scheffleri from Uganda. Ciferri (1954) transferred this taxon to Meliola strombosiae (Hansf.) Cif. Hansford (1961) regarded the new combination of Ciferri (1954) are entirely unnecessary and superfluous "name-making". Subsequent notable works of $\mathrm{Hu}$ et al. (1996, 1999), Hosgoudar (1996, 2008), Mibey \& Hawksworth (1997) have followed Hansford (1961).

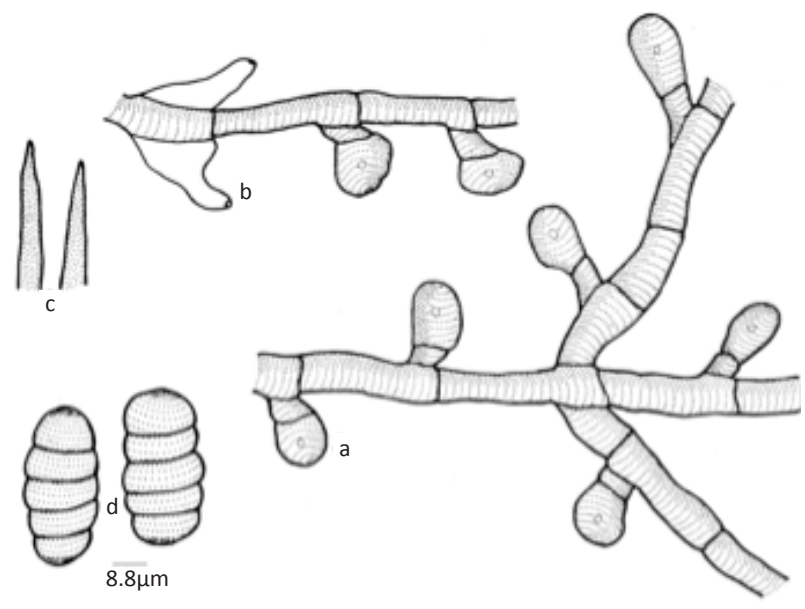

Figure 108. Meliola strebii

a - Appressorium; b - Phialide; c - Apical portion of mycelial setae; d - Ascospores

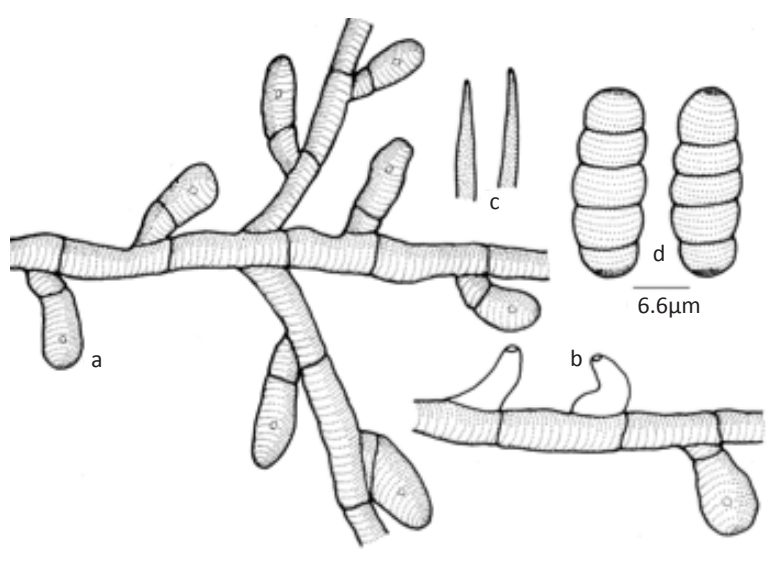

Figure 109. Meliola strombosiicola nom. nov.

a - Appressorium; b - Phialide; c - Apical portion of mycelial setae; d - Ascospores 
Since Meliola strombosiae Hosag. et al. is the homonym of Meliola strombosiae (Hansf.) Cif., a new name has been proposed here.

Meliola strombosiigena Hosag. \& Riju, J. Threatened Taxa 3(3): 1618, 2011. (Fig. 110)

Colonies amphigenous, mostly hypophyllous, dense, velvety, up to $4 \mathrm{~mm}$ diam., confluent. Hyphae flexuous to undulate, branching opposite to alternate at acute to wide angles, loosely to closely reticulate, cells $15-25 \times 5-$ $10 \mu \mathrm{m}$. Appressoria alternate, opposite to unilateral, antrorse to subantrorse, rarely retrorse, 17-28 $\mu \mathrm{m}$ long; stalk cells cylindrical to cuneate, 5-8 $\mu \mathrm{m}$ long; head cells oblong to cylindrical, straight to flexuously curved, entire, 10-20x5-8 $\mu \mathrm{m}$. Phialides mixed with appressoria, alternate, opposite to unilateral, ampulliform, 20-30x6$8 \mu \mathrm{m}$. Mycelial setae straight to curved, scattered, acute at the tip, up to $720 \mu \mathrm{m}$ long; Perithecia scattered in the colonies, up to $240 \mu \mathrm{m}$ in diam.; ascospores obovoidal, 4-septate, constricted at the septa, 50-55×20-23 $\mu \mathrm{m}$.

Material examined: TBGT 4515 (holotype), HClO 50598 (isotype), New Delhi, (MycoBank \# 561023), 01.viii.2008, Kerala, Palakkad, Silent Valley National Park, Cheriavalakkad, on leaves of Strombosia sp. (Olacaceae), M.C. Riju et al.

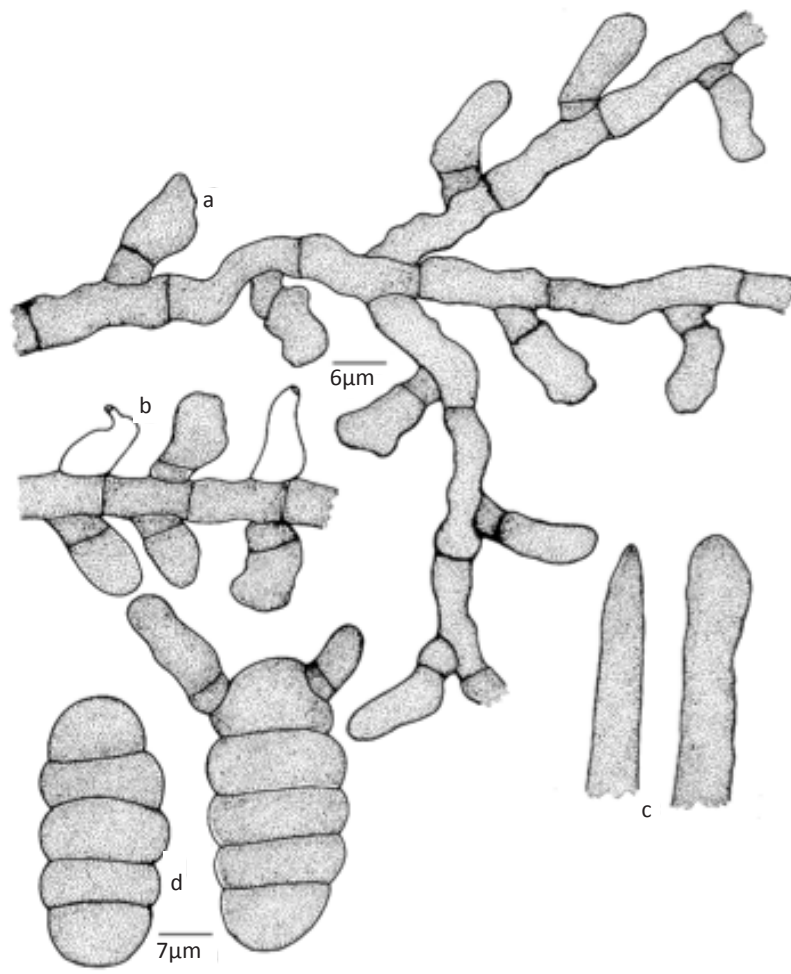

Figure 110. Meliola strombosiigena

a - Appressorium; b - Phialide; c - Apical portion of mycelial setae; d - Ascospores
Meliola strobosiae Hosag. et al. is known on Strombosia ceylonica from Kukke Subramanya, Karnataka (Hosagoudar 2008). However, the present new species differs from it in having narrow head cells (5-8 $\mu \mathrm{m}$ against $8-12 \mu \mathrm{m}$ ) and larger spores $(50-55 \mathrm{x}$ 20-23 against 36-40 x 15-17 $\mu \mathrm{m})$. The specific epithet is derived from the host genus.

Meliola strophanthicola Hansf. var. indica Hosag. \& Jacob Indian J. Sci. Technol. 2(6): 23, 2009. (Fig. 111)

Colonies amphigenous, dense, velvety, up to $4 \mathrm{~mm}$ in diameter, confluent. Hyphae substraight to undulate, branching mostly opposite at acute to wide angles, loosely to closely reticulate, cells $19-26 \times 5-7 \mu \mathrm{m}$. Appressoria alternate, antrorse to subantrorse, spreading, 17-24 $\mu \mathrm{m}$ long; stalk cells cylindrical to cuneate, 6-9 $\mu \mathrm{m}$ long; head cells cylindrical, ovate, entire, 11-15x6-9 $\mu \mathrm{m}$. Phialides mixed with appressoria, opposite to alternate, ampulliform, 13-18 x 5-7 $\mu \mathrm{m}$. Mycelial setae numerous, scattered to grouped around perithecia, simple, straight to curved, acute at the tip, up to $480 \mu \mathrm{m}$ long. Perithecia scattered, verrucose, up to $170 \mu \mathrm{m}$ in diam.; ascospores cylindrical to subellipsoidal, 4-septate, slightly constricted at the septa, 33-38x11-16 $\mu \mathrm{m}$.

Materials examined: HCIO 48017 (holotype), TBGT 2800 (isotype), 1.ii.2007, Kerala, Pathanamthitta, Kozhencherry, St. Thomas College Campus, on leaves of Strophathus wightianus Wallich ex Wight (Apocynaceae), Jacob Thomas.

Two species of the genus Meliola, M. monilispora Gaill. and $M$. strophanthicola Hansf. are known on the host genus Strophanthus from Congo Francoise and Uganda (Hansford 1961). The present collection differs

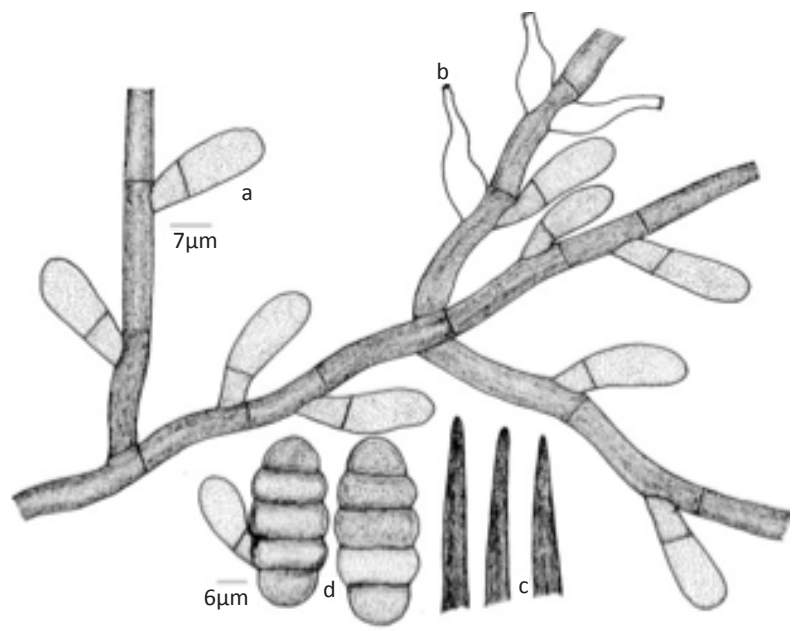

Figure 111. Meliola strophanthicola var. indica

a - Appressorium; b - Phialide; c - Apical portion of mycelial setae; d - Ascospores 
from the former species in having only acute mycelial setae in contrast to all dentate ones. It is similar to the later species but the new variety differs from the var. strophanthicola in having distinctly smaller ascospores

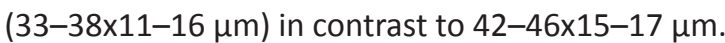

Meliola tabernaemontanae Speg. var. wrightiae Hosag., Agarwal, H. Biju \& Archana, Indian Phytopath. 59: 349, 2006. (Fig. 112)

Colonies amphigenous, sub-dense, up to $2 \mathrm{~mm}$ in diameter, scattered. Hyphae straight to sub straight, branching opposite at wide angles, loosely reticulate, cells 12-35x4-8 $\mu \mathrm{m}$. Appressoria alternate, antrorse, recurved, straight to slightly curved,14-19 $\mu \mathrm{m}$ long; stalk cells cylindrical to cuneate, 3-5 $\mu \mathrm{m}$ long; head cells, ovate, oblong, entire,11-14x6-10 $\mu \mathrm{m}$. Phialides mixed with to obtuse appressoria, ampulliform, opposite, alternate, 12-19x3-8 $\mu \mathrm{m}$. Mycelial setae, simple, acute at the tip, up to $363 \mu \mathrm{m}$ long. Perithecia scattered, verrucose, up to $100 \mu \mathrm{m}$ in diameter; ascospores obovoidal, 4-septate, slightly constricted at the septa, 35-45×14-18 $\mu \mathrm{m}$.

Material examined: HClO 46142 (type), TBGT 1905 (isotype), 13.xi.2003, On leaves of Wrightia tinctoria (Roxb.) R. Br. (Apocynaceae), MPCA, Talakaveri, Karnataka, India, V.B. Hosagoudar et al.

This variety differs from the species type in having straight apical portion of the mycelial setae and larger ascospores.

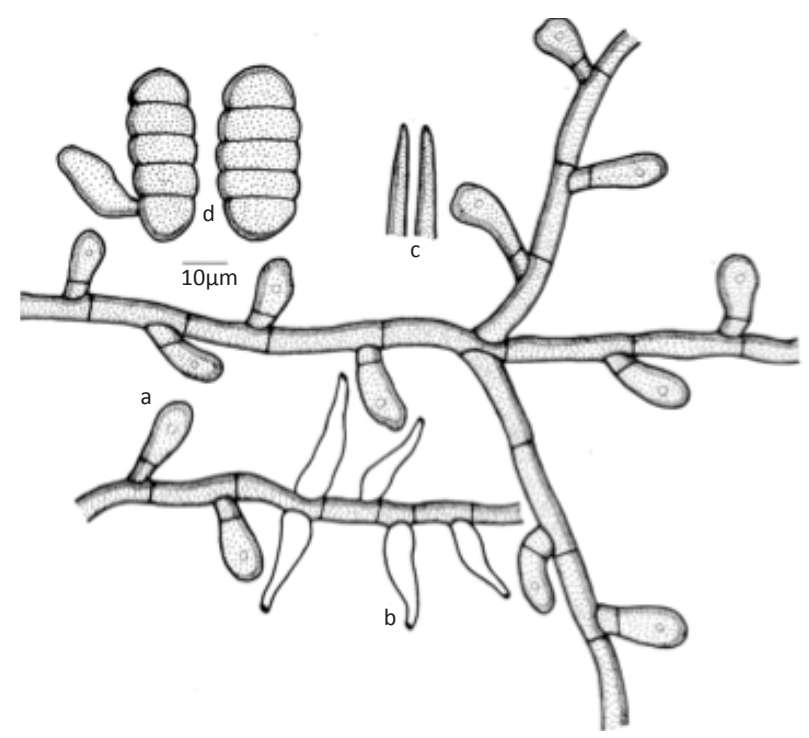

Figure 112. Meliola tabernaemontanae var wrightiae a - Appressorium; b - Phialide; c - Apical portion of mycelial setae d - Ascospores
Meliola vallaridis Hosag., Sabeena., Archana. \& Jacob. J. Scient. Trans. Environ. Techn. 1: 69, 2007. (lamge. 11, Fig. 113)

Colonies amphigenous, mostly epiphyllous, caulicolous, ramicolous, dense, crustose to velvety, up to $2 \mathrm{~mm}$ in diam., confluent. Hyphae straight, substraight to flexuous, branching mostly opposite at acute to wide angles, loosely to very closely reticulate, often form solid mycelial mat, cells 11-18x4-7 $\mu \mathrm{m}$. Appressoria alternate, less than $1 \%$ opposite, antrorse to subantrorse, $17-22 \mu \mathrm{m}$ long; stalk cells cylindrical to cuneate, 4-8 $\mu \mathrm{m}$ long; head cells ovate, oblong to cylindrical, often narrowed towards apex, entire, 11-16x6-9 $\mathrm{mm}$. Phialides numerous, mixed with appressoria, alternate to opposite, ampulliform, 13-22x4-7 $\mu \mathrm{m}$. Mycelial setae numerous, scattered to grouped around perithecia, simple, straight, acute at the tip, up to $450 \mu \mathrm{m}$ long. Perithecia closely scattered, up to $165 \mu \mathrm{m}$ in diam.; ascospores oblong to cylindrical, 4-septate, deeply constricted at the septa, 30-37x11-16 $\mu \mathrm{m}$.

Materials examined: $\mathrm{HClO}$ (holotype), TBGT 2832 (isotype), 8.ii.2007, Kerala, Thiruvananthapuram, Palode, JNTBGRI campus, on leaves of Vallaris solanacea (Roth.) Kuntze (Apocynaceae), Sabeena et al.; TBGT 867, HCIO

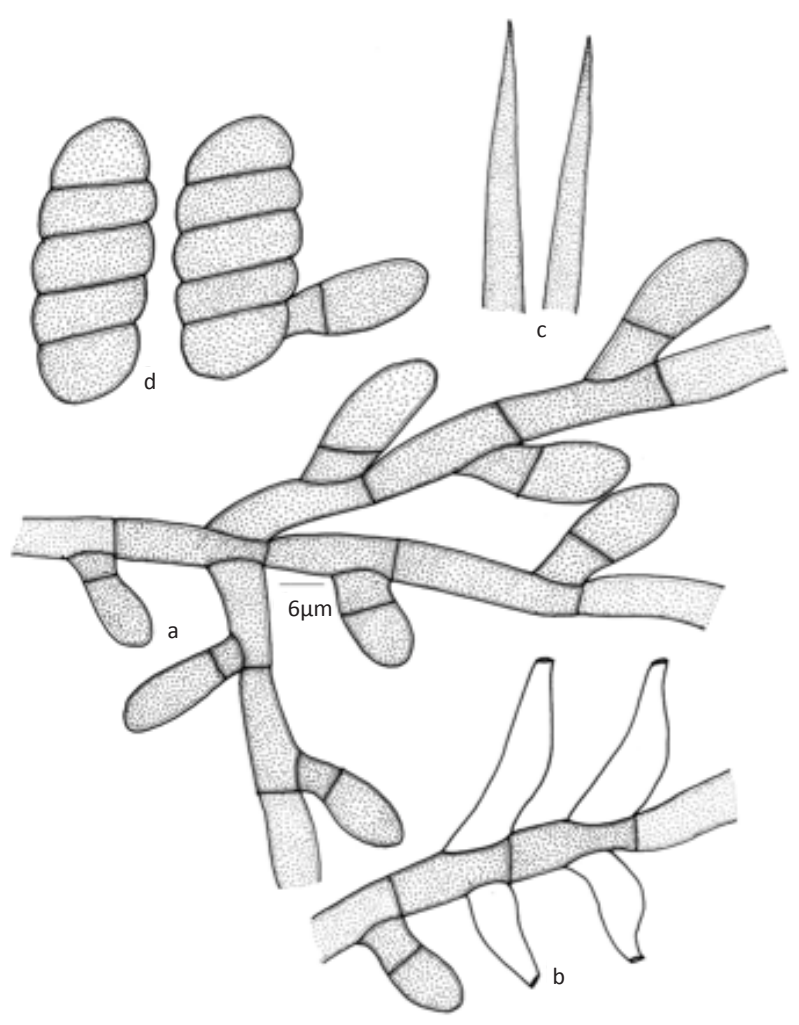

Figure 113. Meliola vallaridis

a - Appressorium; b - Phialide; c - Apical portion of mycelial setae; d - Ascospores 


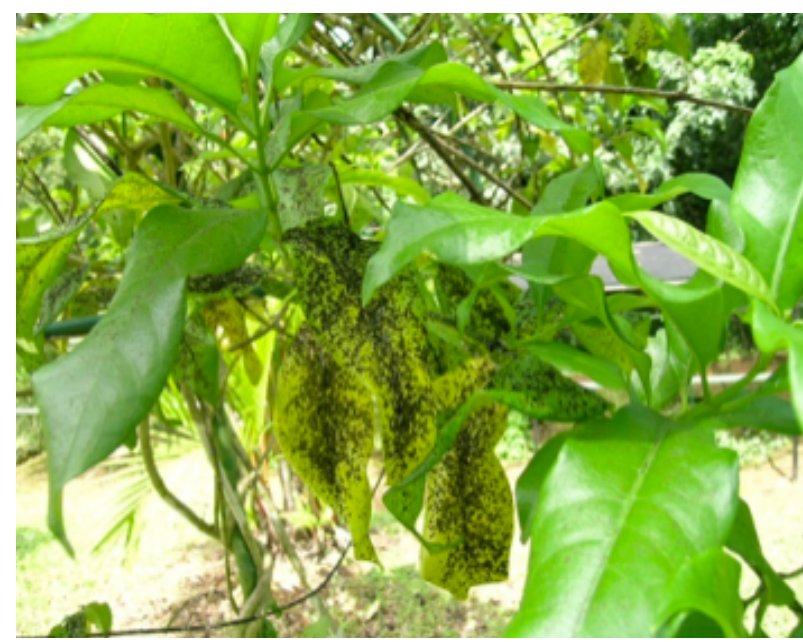

Image 11. Meliola vallaridis infected leaves

44580, 05.i.2001, H. Biju; Thiruvananthapuram, Govt. Museum (Zoo), TBGT 1120, HCIO 44892, 28.xii.2002, G. Rajkumar.

Meliola tabernaemontanicola Hansf. \& Thirum. was described on Tabernaemontana sp. from Balehonnur, Karnataka (Hansford and Thirumalachar, 1948). Kar and Maity (1972) collected Meliola sp. on Vallaris solanacea from Mallickput, West Bengal and attributed it to $M$. tabernaemontanicola. Hosagoudar (1996) procured the slide of the same from IMI (no. 139202) and also placed it under M. tabernaemontanicola. The present collections differ from the assigned species in causing pathological effect in producing yellow haloes around the colonies, infecting leaf petioles, soft and younger stem portions, causing 'shot-holes' and turning the infected leaves yellow and result in withering of such leaves.

Meliola vatsavayae Hosag. \& Riju, Indian J. Sci. Technol. 2(6): 25, 2009. (Image. 12, Fig. 114)

Colonies amphigenous, dense, velvety, scattered to confluent, up to $4 \mathrm{~mm}$ in diameter. Hyphae straight, branching opposite at acute to wide angles, closely reticulate, cells 13-18x6-11 $\mu \mathrm{m}$. Appressoria alternate, rarely unilateral, often crowded, antrorse, straight, 24$40 \mu \mathrm{m}$ long; stalk cells cylindrical to cuneate, $8-13 \mu \mathrm{m}$ long; head cells ovate, angular, sinuately lobate to deeply lobate, 15-27x9-18 $\mu \mathrm{m}$. Phialides mixed with appressoria, mostly opposite, rarely alternate to unilateral, ampulliform, 22-31x4-9 $\mu \mathrm{m}$. Mycelial setae straight to slightly curved, scattered to grouped around perithecia, obtuse at the tip, up to $270 \mu \mathrm{m}$ long. Perithecia scattered, up to $110 \mu \mathrm{m}$ in diam.; ascospores cylindrical to slightly ellipsoidal, 4-septate, constricted at

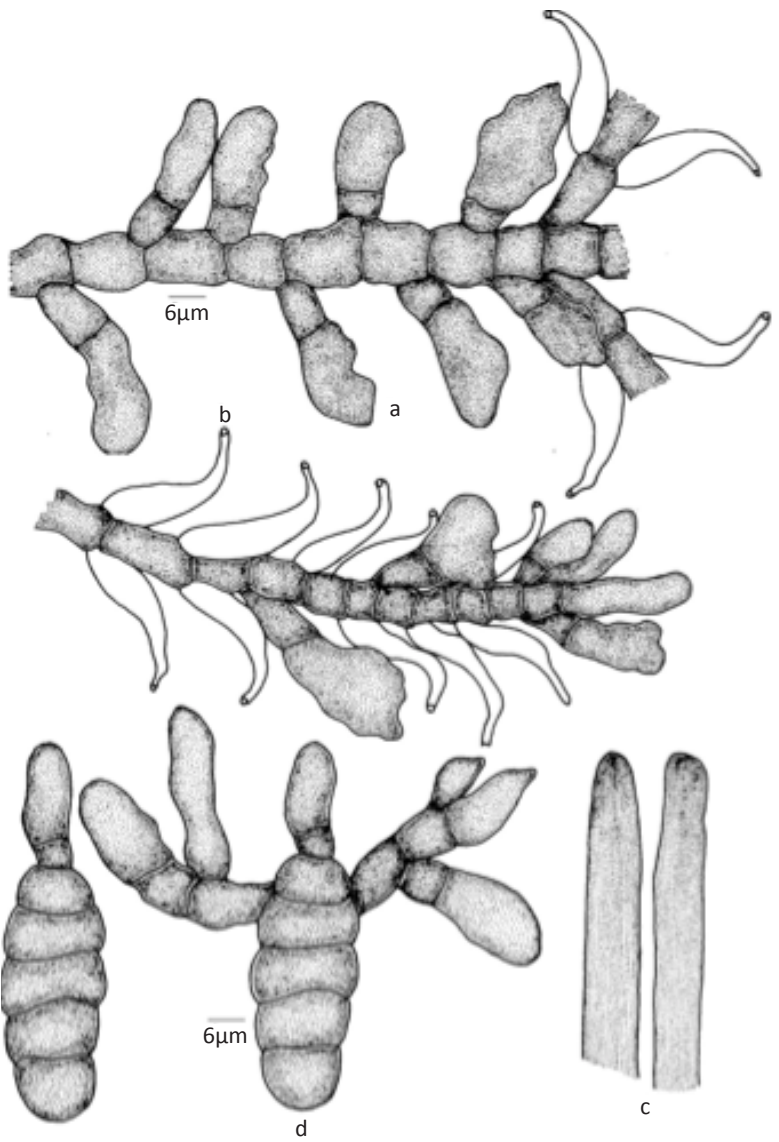

Figure 114. Meliola vatsavayae

a - Appressorium; b - Phialide; c - Apical portion of mycelial setae; d - Ascospores

the septa, 37-44×15-20 $\mu \mathrm{m}$.

Materials examined: $\mathrm{HClO} 48299$ (holotype), TBGT 3018 (holotype), 22.iii.2008, Kerala, Wayanad, Padinharathara, 16th mile, on leaves of Zanthoxylum rhetsa (Roxb) DC. (Rutaceae), M.C. Riju.

Based on the digital formula 3113.4221, this species can be compared with $M$. toddaliicola Hansf. and M.toddaliicola Hanf. indica Hansf. \& Thirum. known on the host genus Toddalia from Uganda and respectively. However, the present new species differs from both in having angular, sinuately to deeply lobate head cells of the appressoria (Hansford 1961; Hosagoudar 1996, 2008; Hosagoudar et al. 1997).

This species is named in honour of Prof. Vatsavaya S. Raju, Professor in Kakatiya University, Warangal, Andhra Pradesh, whose association and friendship triggered interest of the senior author (VBH) in this group around three decades ago. 


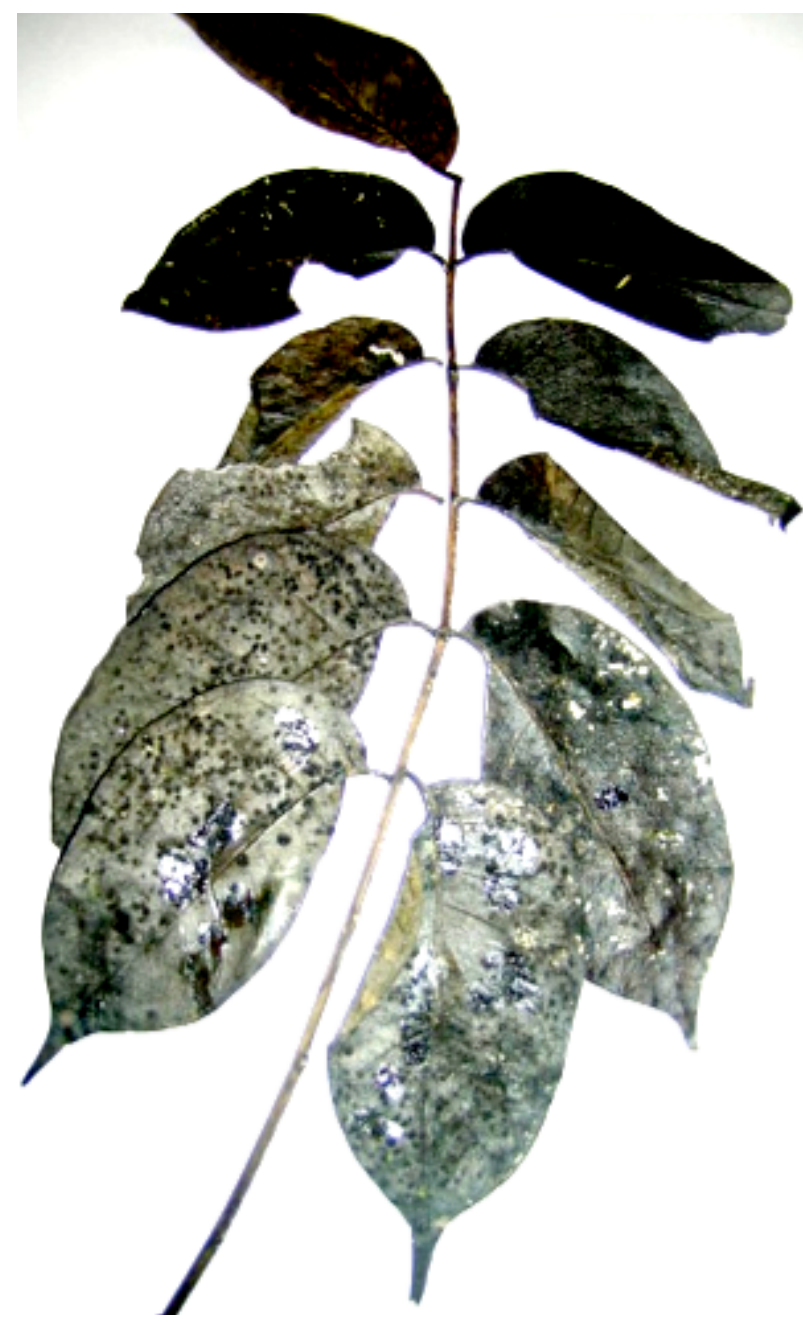

Image 12. Meliola vatsavayae infected leaves

Meliola vazhachalensis Hosag. \& Jacob, Indian J. Sci. Technol. 2(6): 24, 2009. (Fig. 115)

Colonies epipyllous, subdense, velvety, up to $4 \mathrm{~mm}$ in diameter, confluent. Hyphae straight, branching opposite at acute angles, loosely to closely reticulate, cells 12-28x5-7 $\mu \mathrm{m}$. Appressoria opposite, antrorse, to subantrorse to spreading, 12-17 $\mu \mathrm{m}$ long; stalk cells cylindrical to cuneate, 2-5 $\mu \mathrm{m}$ long; head cells ovate, cylindrical, slightly attenuated and broadly rounded at the apex, entire, 9-15x7-10 $\mu \mathrm{m}$. Phialides mixed with appressoria, alternate to opposite, ampulliform, 1422x5-9 $\mu \mathrm{m}$. Mycelial setae grouped around perithecia, simple, uncinate to slightly coiled, acute at the tip, up to $220 \mu \mathrm{m}$ long. Perithecia scattered, verrucose, up to $140 \mu \mathrm{m}$ in diam.; ascospores cylindrical to obovoidal, 4-septate, constricted at the septa, 28-36x12-15 $\mu \mathrm{m}$.

Materials examined: $\mathrm{HClO} 48206$ (holotype), TBGT 2942 (isotype), 12.xi.2007, On leaves of Aglaia sp. (Meliaceae), Lower Sholayar, Vazhachal, Thrissur, Kerala,

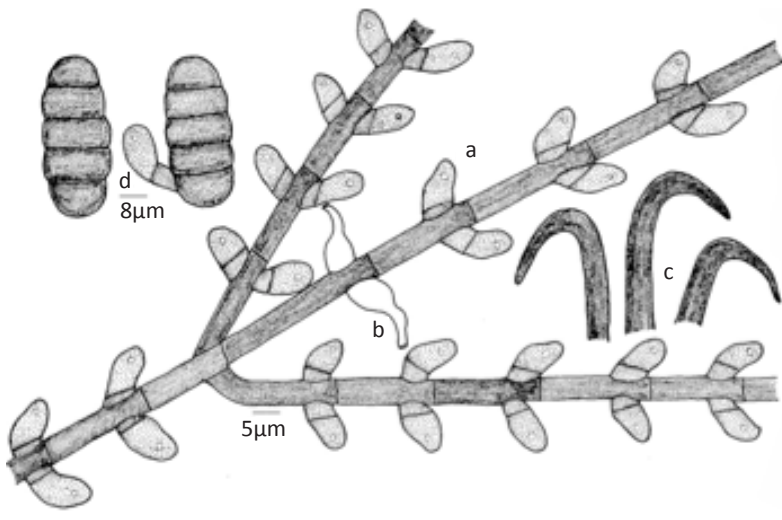

Figure 115. Meliola vazhachalensis

a - Appressorium; b - Phialide; c - Apical portion of mycelial setae;

$\mathrm{d}$ - Ascospores

Jacob Thomas et al.

This species can be compared with Meliola reinwardtiodendri Hosag. known on Reinwardtiodendron anamallayanum (Bedd.) from Anamalai forests, Coimbatore, Tamil Nadu having opposite appressoria with uncinate mycelial setae. The new species differs from it having distinctly attenuated head cells of appressoria in contrast to broadly rounded to truncate ones (Hosagoudar 1996).

\section{REFERENCES}

Biju, C.K., V.B. Hosagoudar \& T.K. Abraham (2005). Meliolaceae of Kerala, India - XV. Nova Hedwigia 80: 465-502.

Ciferri, R. (1954). Meliolae of Santo Domingo. Mycopathologia 7: 81-211.

Goos, R.D. \& V.B. Hosagoudar (1998). Meliola chennaiana sp. nov. and some additional records of fungi from India. Mycotaxon 68: 41-46.

Hansford, C.G. (1946). The foliicolous Ascomycetes and their parasites and associated fungi. Mycological Papers 15: 1-240.

Hansford, C.G. (1961). The Meliolaceae. A Monograph. Sydowia. Beih 2: 1-806.

Hansford, C.G. (1963b). Iconographia Meliolinearum. Verlag Von Fordin und Berger, Horn, No. Austria, 285 Plates.

Hansford, C.G. \& M.J. Tirumalachar (1948). Fungi of South India. Farlowia 3: 285-314.

Hosagoudar, V.B. (1996). Meliolales of India. Botanical Survey of India, Calcutta, 363pp.

Hosagoudar, V.B. (2005). Meliolaceae of Kerala, India - XXI. New species and New records. Journal of Mycopathological Research 43: 17-32.

Hosagoudar, V.B. (2008). Meliolales of India. Vol. II. Botanical Survey of India, Calcutta, 390pp.

Hosagoudar, V.B. \& T.K. Abraham (1998). Some interesting meliolaceous fungi from Kerala, India. Journal of Mycopathological Research 36: 95-103.

Hosagoudar, V.B., T.K. Abraham \& C.K. Biju (2001). Meliolaceae of Kerala, India - IX. Journal of Economic and Taxonomic Botany 25: 553-559.

Hosagoudar, V.B., T.K. Abraham \& P. Pushpangadan (1997). The Meliolineae - A Supplement. Tropical Botanic Garden and Research Institute, Palode, Thiruvananthapuram, Kerala, India, 201pp. 
Hosagoudar, V.B., T.K. Abraham \& R.D. Goos (1998). Three new species of the Meliolaceae from Kerala, India. Mycotaxon 63: 493-496.

Hosagoudar, V.B. \& D.K. Agarwal (2008). Taxonomic studies of Meliolales. Identification Manual. International Book Distributors, Dehra Dun, 263pp.

Hosagoudar, V.B. \& R.D. Goos (1991). Meliolaceous fungi from the state of Kerala, India-II. Mycotaxon 37: 217-272.

Hosagoudar, V.B. \& R.D. Goos (1991). Meliolaceae of south India - X. Mycotaxon 42: 125-147.

Hu, Y., Y. Ouyang, S. Bin \& G. Jiang (1996). Flora Fungorum Sinicorum Vol. 4. Meliolales (1) : Science Press Beijing pp. 270, plate IV.

Hu, Y., S. Bin, Y. Ouyang \& G. Jiang (1999). Flora Fungorum Sinicorum Vol. 11. Meliolales (2): Science Press Beijing 252pp.

Jana, T.K., S.N. Gosh \& A.K. Das (2005). Meliolaceae of Nagaland
(India) -III. Journal of Mycopathological Research 43: 159-166.

Kar, A.K. \& M.K. Maity (1972). Pyrenomycetes of West Bengal (India)-V. Norway Journal of Botany 19: 243-251.

Mibey, R.K. \& D.L. Hawksworth (1997). Meliolaceae and Asterinaceae of the Shimba Hills, Kenya. Mycological Papers 174: 1-108.

Mibey, R.K. \& P.F. Cannon (1999). Biotrophic fungi from Kenya. Ten new species and some new records of Meliolaceae. Cryptogamie Mycologicae 20: 249-282.

Nayar, T.S., A.R. Beegam, N. Mohanan \& G. Rajkumar (2006). Flowering plants of Kerala- A hand book. Tropical Botanic Garden and Research Institute, Thiruvananthapuram, Kerala.

Patil, M.S. \& S.H. Mahamulkar (1999). Studies on Meliolaceae of India -IV. Indian Phytopathology 52: 245-253. 


\section{KEY TO THE SPECIES OF MELIOLALES}

\begin{tabular}{|c|c|c|}
\hline & ALANGIACEAE & \\
\hline \multirow[t]{2}{*}{$\begin{array}{l}\text { Meliola } \\
3113.3222\end{array}$} & $\begin{array}{l}\text { Colonies epiphyllous, thin; hyphae substraight to undulating; appressoria alternate, } 30 \% \text { opposite, } \\
\text { antrorse, subantrorse to retrorse, head cells cylindrical, oblong, globose, ovoid, broadly rounded to } \\
\text { truncate and often narrowed towards its apex, entire; phialides mixed with appressoria; mycelial setae } \\
\text { numerous, scattered, simple, straight, acute to obtuse at the tip }\end{array}$ & Meliola alangii var. salvifolii \\
\hline & ANACARDIACEAE & \\
\hline $\begin{array}{l}\text { Meliola } \\
3111.4222\end{array}$ & $\begin{array}{l}\text { Colonies amphigenous, mostly hypophyllous, thin; hyphae straight to substraight; appressoria } \\
\text { alternate, closely arranged on the hyphae antrorse to subantrorse; head cells ovate, entire; phialides } \\
\text { mixed with appressoria; mycelial setae simple, straight }\end{array}$ & Meliola gluticola \\
\hline \multirow[t]{2}{*}{3143.4321} & $\begin{array}{l}\text { Colonies epiphyllous, dense, velvety; hyphae straight; closely reticulate and form a mycelial net; } \\
\text { appressoria alternate, up to } 5 \% \text { opposite, antrorse to retrorse, straight to curved; head cells cylindrical } \\
\text { to clavate, curved, entire, truncate, angular to rarely sublobate; phialides mixed with appressoria; } \\
\text { mycelial setae scattered, fairly numerous, simple, straight, dichotomously branched }\end{array}$ & Meliola sanjappai \\
\hline & APOCYNACEAE & \\
\hline $\begin{array}{l}\text { Meliola } \\
3111.3222\end{array}$ & $\begin{array}{l}\text { Colonies amphigenous, mostly epiphyllous, dense, velvety; hyphae straight to substraight, ; } \\
\text { appressoria alternate, about } 5 \% \text { unilateral, straight to curved, antrorse to spreading; head cells } \\
\text { globose to subglobose, ovate, entire; phialides mixed with appressoria; mycelial setae numerous, } \\
\text { scattered, straight. }\end{array}$ & Meliola ichnocarpi-volubili \\
\hline $31 \frac{1}{4} 1.3221$ & $\begin{array}{l}\text { Colonies hypophyllous, scattered, dense, velvety, hyphae straight to substraight, appressoria alternate, } \\
\text { unilateral, straight, antrorse, head cells ovate, globose, mycelial setae numerous, up to } 260 \mu \mathrm{m} \text { long, } \\
\text { simple, straight, few slightly curved to uncinate, obtuse, bifid, trifid, often subdentate to furcated to } \\
\text { branched at the tip }\end{array}$ & Meliola kamettiae \\
\hline 3111.3222 & $\begin{array}{l}\text { Colonies amphigenous, mostly epiphyllous, caulicolous, ramicolous, dense, crustose to velvety; } \\
\text { hyphae straight, substraight to flexuous; appressoria alternate, less than } 1 \% \text { opposite, antrorse to } \\
\text { subantrorse; head cells ovate, oblong to cylindrical, often narrowed towards apex, entire; phialides } \\
\text { numerous, mixed with appressoria; mycelial setae numerous, scattered to grouped around perithecia, } \\
\text { simple, straight, acute at the tip }\end{array}$ & Meliola vallaridis \\
\hline 3111.3222 & $\begin{array}{l}\text { Colonies amphigenous, dense, velvety; hyphae substraight to undulate; appressoria alternate, } \\
\text { antrorse to subantrorse, spreading; head cells cylindrical, ovate, entire; phialides mixed with } \\
\text { appressoria; mycelial setae numerous, scattered to grouped around perithecia, simple, straight to } \\
\text { curved, acute at the tip }\end{array}$ & $\begin{array}{l}\text { Meliola strophanthicola var. } \\
\text { indica }\end{array}$ \\
\hline \multirow[t]{2}{*}{3111.4212} & $\begin{array}{l}\text { Colonies amphigenous, sub-dense; hyphae straight to sub straight; appressoria alternate, antrorse, } \\
\text { recurved, straight to slightly curved, head cells, ovate, oblong, entire; phialides mixed with to obtuse } \\
\text { appressoria; mycelial setae, simple, acute at the tip }\end{array}$ & $\begin{array}{l}\text { Meliola tabernaemontanae } \\
\text { var. wrightiae }\end{array}$ \\
\hline & ARALIACEAE & \\
\hline \multirow[t]{2}{*}{$\begin{array}{l}\text { Meliola } \\
31 \frac{1}{3} 1.3232\end{array}$} & $\begin{array}{l}\text { Colonies epiphyllous, crustose; hyphae straight to flexuous; appressoria alternate, unilateral, antrorse } \\
\text { to subantrorse, head cells globose, subglobose, entire, phialides mixed with appressoria, mostly } \\
\text { opposite, rarely alternate; mycelial setae simple, straight, obtuse, clavate, inflated, notched to bifid at } \\
\text { the apex, ends broadly rounded }\end{array}$ & Meliola abdulkalamii \\
\hline & ARISTOLOCHIACEAE & \\
\hline \multirow[t]{2}{*}{$\begin{array}{l}\text { Meliola } \\
3113.3222\end{array}$} & $\begin{array}{l}\text { Colonies epiphyllous, thin to dense; hyphae substraight to flexuous; appressoria alternate to about } \\
3 \% \text { opposite, antrorse to subantrorse, head cells ovate to globose, entire; phialides mixed with } \\
\text { appressoria; mycelial setae scattered, simple, straight, acute to obtuse at the tip }\end{array}$ & Meliola aristolochigena \\
\hline & ASCLEPIADACEAE & \\
\hline $\begin{array}{l}\text { Meliola } \\
3113.5221\end{array}$ & $\begin{array}{l}\text { Colonies amphigenous, mostly epiphyllous; hyphae straight to substraight; appressoria opposite, about } \\
5 \% \text { alternate, antrorse, straight to curved, head cells ovate cylindrical, entire; phialides few, borne on } \\
\text { a separate mycelial branch; mycelial setae numerous, scattered to grouped around perithecia, simple, } \\
\text { straight to slightly curved, acute to obtuse at the tip }\end{array}$ & Meliola buxaduarii \\
\hline \multirow[t]{2}{*}{$31 \frac{1}{23} 3.4223$} & $\begin{array}{l}\text { Colonies epiphyllous, thin to dense; hyphae straight, substraight to flexuous; appressoria alternate, } \\
\text { about } 20 \% \text { opposite, antrorse to subantrorse, head cells globose to ovate, entire; phialides mixed } \\
\text { with appressoria, alternate to opposite, ampulliform; mycelial setae many, densely scattered, simple, } \\
\text { straight to curved, very few uncinate, obtuse, dentate, cristate, often furcate up to } 20 \mu \mathrm{m} \text { at the tip }\end{array}$ & Meliola cynanchi \\
\hline & BURSERACEAE & \\
\hline $31 \frac{1}{3} 1.4222$ & $\begin{array}{l}\text { Colonies amphigenous, mostly epiphyllous; hyphae straight to substraight; appressoria alternate } \\
\text { to unilateral, antrorse to subantrorse; head cells ovate, globose, entire; phialides mixed with } \\
\text { appressoria; mycelial setae numerous, scattered, straight, dentate, cristate, bifid to obtuse at the tip }\end{array}$ & Meliola garugae \\
\hline
\end{tabular}




\begin{tabular}{|c|c|c|}
\hline & CAESALPINIACEAE & \\
\hline 3113.4222 & $\begin{array}{l}\text { Colonies epiphyllous; hyphae substraight to undulating, branching opposite to unilateral at acute to } \\
\text { wide angles, loosely reticulate; appressoria opposite, alternate to unilateral, antrorse, subantrorse } \\
\text { to retrorse, head cells ovate, globose, straight to curved, entire; phialides mixed with appressoria; } \\
\text { mycelial setae many, scattered, simple, straight, acute to obtuse at the tip }\end{array}$ & $\begin{array}{l}\text { Meliola bauhiniicola var. } \\
\text { brevipoda }\end{array}$ \\
\hline \multirow[t]{2}{*}{$31 \frac{1}{2} 3.5231$} & $\begin{array}{l}\text { Colonies amphigenous, subdense to dense; hyphae straight to substraight; appressoria opposite, } \\
\text { unilateral, } 2 \% \text { alternate, antrorse to subantrorse, head cells ovate, globose, oblong, entire; phialides } \\
\text { mixed with appressoria; mycelial setae numerous, simple, straight to uncinate, acute at the tip }\end{array}$ & Meliola caesalpiniicola \\
\hline & CELASTRACEAE & \\
\hline $\begin{array}{l}\text { Meliola } \\
3111.3222\end{array}$ & $\begin{array}{l}\text { Colonies mostly epiphyllous, rarely amphigenous, dense to subdense; hyphae substraight; appressoria } \\
\text { alternate, antrorse, head cells ovate, globose, entire; phialides mixed with appressoria; mycelial setae } \\
\text { many, simple, straight, acute to obtuse at the tip }\end{array}$ & Meliola pleurostylicola \\
\hline 3113.4233 & $\begin{array}{l}\text { Colonies epiphyllous, dense, velvety; hyphae straight to substraight; appressoria opposite, about } 3 \% \\
\text { alternate, arranged after an intermittent interval (in most places mycelium devoid of appressoria), } \\
\text { closely antrorse, antrorse to subantrorse; head cells ovate, globose, entire, angular to slightly lobate; } \\
\text { phialides mixed with appressoria; mycelial setae numerous, scattered, simple, straight, acute to } \\
\text { obtuse at the tip. }\end{array}$ & Meliola lophopetaligena \\
\hline \multirow[t]{2}{*}{3111.5322} & $\begin{array}{l}\text { Colonies amphigenous, subdense; hyphae substraight to flexuous; appressoria alternate, straight to } \\
\text { slightly curved, antrorse, subantrorse to retrorse, head cells ovate, globose, clavate, oblong, irregularly } \\
\text { deeply lobate, rarely angular; phialides mixed with appressoria; mycelia setae simple, scattered, } \\
\text { straight to slightly curved, acute to obtuse at the tip }\end{array}$ & Meliola euonymi \\
\hline & CLUSIACEAE & \\
\hline \multirow[t]{2}{*}{3113.4221} & $\begin{array}{l}\text { Colonies amphigenous, mostly epiphyllous, dense; hyphae straight; appressoria alternate, about } 2 \% \\
\text { opposite, closely arranged, antrorse to subantrorse, straight to curved; head cells ovate to globose, } \\
\text { entire, rarely angular; phialides mixed with appressoria; mycelial setae few, straight, simple, acute at } \\
\text { the tip }\end{array}$ & Meliola mesuae \\
\hline & COMBRETACEAE & \\
\hline \multirow[t]{2}{*}{$31 \frac{1}{2} 1.3223$} & $\begin{array}{l}\text { Colonies epiphyllous, thin; hyphae substraight to flexuous; appressoria alternate, unilateral, antrorse, } \\
\text { head cells globose, ovate, entire to slightly angular; phialides mixed with appressoria; mycelial setae } \\
\text { numerous, simple, straight to uncinate, acute to obtuse at the tip }\end{array}$ & Meliola calycopteridis sp. nov. \\
\hline & CYPERACEAE & \\
\hline \multirow[t]{2}{*}{ Meliola 3111.3222} & $\begin{array}{l}\text { Colonies amphigenous, dense, velvety; hyphae straight to substraight; appressoria alternate, straight } \\
\text { to curved, head cells cylindrical, globose, slightly angular, sublobate to lobate, often truncate at the } \\
\text { apex; phialides borne on a separate mycelial branch; mycelial setae straight, simple, acute to obtuse } \\
\text { at the tip }\end{array}$ & Meliola cyperacearum \\
\hline & DIOSCOREACEAE & \\
\hline $31 \frac{1}{3} 3.3223$ & $\begin{array}{l}\text { Colonies epiphyllous, dense, velvety; hyphae straight; appressoria alternate, about } 3 \% \text { opposite, } \\
\text { antrorse to subantrorse, straight to curved; head cells curved, cylindrical, ovate, entire, rounded at the } \\
\text { apex; phialides mixed with appressoria; mycelial setae scattered, straight, simple, acute to dentate at } \\
\text { the tip }\end{array}$ & Meliola dioscoreacearum \\
\hline \multirow[t]{2}{*}{3112.4222} & $\begin{array}{l}\text { Colonies epiphyllous, dense, velvety; hyphae straight to substraight; appressoria opposite, less than } \\
1 \% \text { alternate, antrorse to spreading, straight to slightly curved; head cells subglobose to ovate, entire; } \\
\text { phialides mixed with appressoria; mycelial setae scattered to grouped around perithecia, straight, } \\
\text { simple, acute to obtuse at the tip }\end{array}$ & Meliola dioscoregena \\
\hline & EBENACEAE & \\
\hline Meliola 3113.4222 & $\begin{array}{l}\text { Colonies amphigenous, subdense; hyphae substraight to crooked; appressoria opposite, alternate, } \\
\text { unilateral, antrorse, subantrorse to retrorse, straight to curved, head cells oblong, ovate, cylindrical, } \\
\text { globose, straight to differently curved, entire to angular; phialides mixed with appressoria; mycelial } \\
\text { setae, simple, straight, acute at the tip }\end{array}$ & Meliola ebeni \\
\hline \multirow[t]{2}{*}{3111.3222} & $\begin{array}{l}\text { Colonies amphigenous, mostly epiphyllous, thin, Hyphae straight to substraight, Appressoria alternate, } \\
\text { very rarely opposite, antrorse, subantrorse to retrorse, head cells ovate, globose, entire, Phialides } \\
\text { mixed with appressoria; mycelial setae simple, straight, acute to obtuse at the tip }\end{array}$ & Meliola diospyri-buxifoliae \\
\hline & ELAEOCARPACEAE & \\
\hline $\begin{array}{l}\text { Amazonia } \\
3101.4220\end{array}$ & $\begin{array}{l}\text { Colonies amphigenous, thin; hyphae straight to flexuous; appressoria alternate, unilateral, antrorse to } \\
\text { retrorse, straight to curved, head cells ovate, oblong, cylindrical, straight to curved, entire to angular, } \\
\text { broadly rounded to truncate at the apex; phialides mixed with appressoria }\end{array}$ & Amazonia elaeocarpi \\
\hline $\begin{array}{l}\text { Appendiculella } \\
3201.3220\end{array}$ & $\begin{array}{l}\text { Colonies epiphyllous, subdense; hyphae straight to undulate; appressoria alternate, antrorse to } \\
\text { subantrorse; head cells globose, ovate, entire, } 12-14 \times 7-10 \mu \mathrm{m} \text {; phialides mixed with appressoria; } \\
\text { perithecial appendages conoid, straight to curved, horizontally striated, attenuated to broadly } \\
\text { rounded at the apex. }\end{array}$ & Appendiculella elaeocarpi \\
\hline
\end{tabular}




\begin{tabular}{|c|c|c|}
\hline & EUPHORBIACEAE & \\
\hline $\begin{array}{l}\text { Asteridiella } \\
3101.3220\end{array}$ & $\begin{array}{l}\text { Colonies amphigenous, thin; hyphae straight to flexuous; appressoria alternate, unilateral, antrorse, } \\
\text { head cells globose, ovate, entire; phialides mixed with appressoria; perithecial wall cells conoid to } \\
\text { mammiform }\end{array}$ & Asteridiella crotonis-caudati \\
\hline 3101.3220 & $\begin{array}{l}\text { Colonies amphigenous, thin; hyphae substraight, flexuous to crooked; appressoria alternate to } \\
\text { unilateral, antrorse, subantrorse to retrorse, straight to curved; head cells ovate, globose, entire, } \\
\text { angular; phialides mixed with appressoria; perithecial wall cells conoid }\end{array}$ & Asteridiella sebastianiae \\
\hline 3101.4220 & $\begin{array}{l}\text { Colonies epiphyllous, dense; hyphae substraight to flexuous; appressoria alternate, antrorse, } \\
\text { subantrorse to reflexed, straight to variously curved, stalk cells rarely up to } 2 \text {-septate, head cells ovate, } \\
\text { globose, cylindrical, entire, angular to rarely sublobate, very few attenuated at the apex; phialides } \\
\text { numerous, apparently borne on a separate mycelium but mixed with appressoria, perithecial wall cells } \\
\text { conoid, projected, attenuated at the apex, up to } 20 \mu \mathrm{m} \text { high ascospores straight to slightly curved }\end{array}$ & Asteridiella chowrirae \\
\hline $\begin{array}{l}\text { Meliola } \\
311 / 23.4321\end{array}$ & $\begin{array}{l}\text { Colonies hypophyllous, subdense; hyphae straight to substraight; appressoria mostly opposite, } \\
\text { alternate, straight to curved, antrorse, subantrorse to retrorse, head cells ovate, oblong, entire to } \\
\text { predominantly angular; mycelial setae simple, crooked, uncinate, obtuse at the tip. }\end{array}$ & Meliola erumeliensis \\
\hline 3113.4222 & $\begin{array}{l}\text { Colonies amphigenous, mostly hypophyllous, crustose; hyphae straight to substraight; appressoria } \\
\text { alternate, about } 15 \% \text { opposite, antrorse to subantrorse, spreading, head cells ovate, clavate, globose, } \\
\text { entire to } 2-5 \text {-times lobate, often slightly angular; phialides mixed with appressoria; mycelial setae few, } \\
\text { simple, straight, obtuse at the tip }\end{array}$ & Meliola aporusae \\
\hline \multirow[t]{2}{*}{3111.4323} & $\begin{array}{l}\text { Colonies mostly hypophyllous, subdense, velvety; hyphae crooked; appressoria alternate to unilateral, } \\
\text { straight to curved, antrorse to subantrorse, head cells globose to ovate, entire, angular to lobate; } \\
\text { phialides mixed with appressoria; mycelial setae scattered, simple, straight }\end{array}$ & Meliola homonoiae \\
\hline & FABACEAE & \\
\hline $\begin{array}{l}\text { Meliola } \\
31 \frac{1}{3} 3.3223\end{array}$ & $\begin{array}{l}\text { Colonies epiphyllous, dense, velvety; hyphae substraight to undulate; appressoria alternate to opposite, } \\
\text { antrorse to spreading, straight to curved; head cells globose to subglobose, ovate, cylindrical, entire; } \\
\text { phialides mixed with appressoria; mycelial setae numerous, scattered, simple, straight to slightly curved, } \\
\text { acute, dentate to cristate at the tip }\end{array}$ & $\begin{array}{l}\text { Meliola pseudarthriae var. } \\
\text { indica }\end{array}$ \\
\hline $31 \frac{1}{3} 1.3223$ & $\begin{array}{l}\text { Colonies epiphyllous, subdense, crustose; hyphae straight, branching opposite at acute to subacute } \\
\text { angles, loosely reticulate; appressoria alternate, about } 1 \% \text { opposite, antrorse to spreading, straight } \\
\text { to curved; head cells ovate to oblong, entire, rounded at the apex; phialides mixed with appressoria; } \\
\text { mycelial setae fairly numerous, scattered, straight, simple, acute to dentate at the tip }\end{array}$ & Meliola aganopes \\
\hline 3113.4222 & $\begin{array}{l}\text { Colonies epiphyllous, thin; hyphae substraight to slightly undulate, branching opposite at acute } \\
\text { to wide angles, loosely to closely reticulate; appressoria alternate, } 5 \% \text { unilateral, } 5 \% \text { opposite, } \\
\text { antrorse to spreading, straight to curved; head cells subglobose, clavate, entire; phialides mixed } \\
\text { with appressoria; mycelial setae numerous, scattered to grouped around perithecia, straight, simple, } \\
\text { acute to obtuse at the tip }\end{array}$ & Meliola erythrinae var. indica \\
\hline $31 \frac{1}{3} 3.4222$ & $\begin{array}{l}\text { Colonies amphigenous, mostly epiphyllous, dense, velvety; hyphae straight to substraight; appressoria } \\
\text { alternate, about } 5 \% \text { opposite, antrorse, curved; head cells globose to subglobose, straight to curved, } \\
\text { entire; phialides mixed with appressoria; mycelial setae numerous, scattered, straight, simple, acute } \\
\text { to dentate at the tip }\end{array}$ & Meliola abrupta \\
\hline 3113.3221 & $\begin{array}{l}\text { Colonies amphigenous, caulicolous, dense, hyphae substraight, flexuous to crooked, appressoria } \\
\text { alternate, about } 2 \% \text { opposite, antrorse to subantrorse, head cells ovate, globose, straight to curved, } \\
\text { entire, phialides mixed with appressoria, mycelial setae few, scattered, simple, straight, obtuse at the } \\
\text { tip }\end{array}$ & Meliola pycnosporae \\
\hline 3113.3222 & $\begin{array}{l}\text { Colonies foliicolous, fructicolous, epiphyllous, thin, scattered, hyphae undulating, appressoria } \\
\text { alternate, unilateral, up to } 3 \% \text {, opposite, straight to slightly curved, subantrorse to retrorse, head cells } \\
\text { ovate, globose, mycelial setae scattered, simple, straight to slightly curved, acute to obtuse }\end{array}$ & Meliola psophocarpi \\
\hline 3111.3222 & $\begin{array}{l}\text { Colonies epiphyllous, thin, scattered; hyphae flexuous to crooked; appressoria alternate to unilateral, } \\
\text { up to } 1 \% \text { opposite, antrorse, subantrorse to retrorse, head cells globose, ovate, straight to curved, } \\
\text { Phialides mixed with appressoria; mycelial setae scattered to grouped around perithecia, simple, } \\
\text { straight, acute at the tip }\end{array}$ & Meliola abri \\
\hline 3111.3222 & $\begin{array}{l}\text { Colonies foliicolous, epiphyllous, thin, scattered; hyphae flexuous to undulate; appressoria alternate, } \\
\text { unilateral, rarely opposite, straight to slightly curved, antrorse, subantrorse to retrorse, head cells } \\
\text { ovate, globose; phialides mixed with appressoria; mycelial setae scattered to grouped around } \\
\text { perithecia, simple, straight to slightly curved, acute to obtuse at the tip }\end{array}$ & Meliola canavaliae \\
\hline $311 \times .4233$ & $\begin{array}{l}\text { Colonies epiphyllous, effuse, black; hyphopodia dark brown; setae dark brown, straight to slightly } \\
\text { curve, acuminate }\end{array}$ & Meliola ougeinae \\
\hline 3111.3222 & $\begin{array}{l}\text { Colonies epiphyllous, dense; hyphae flexuous to crooked; appressoria alternate, antrorse to } \\
\text { subantrorse, head cells ovate, globose, straight to curved, entire, rarely slightly angular; phialides } \\
\text { borne on a separate mycelial branch; mycelial setae scattered, simple, straight, acute to obtuse at the } \\
\text { tip }\end{array}$ & $\begin{array}{l}\text { Meliola desmodii-laxiflori var. } \\
\text { indica }\end{array}$ \\
\hline
\end{tabular}




\begin{tabular}{|c|c|c|}
\hline & FAGACEAE & \\
\hline $\begin{array}{l}\text { Asteridiella } \\
3101.4220\end{array}$ & $\begin{array}{l}\text { Colonies amphigenous, mostly epiphyllous, hyphae substraight to slightly undulate, appressoria } \\
\text { alternate, antrorse to sub antrorse, head cells ovate, globose, entire, angular to slightly lobate, } \\
\text { phialides mixed with appressoria, ascospores obovoidal to cylindrical, 3-septate }\end{array}$ & Asteridiella phukanea \\
\hline \multirow[t]{2}{*}{$\begin{array}{l}\text { Meliola } \\
311 \frac{1}{3} 3.4223\end{array}$} & $\begin{array}{l}\text { Colonies epiphyllous, thin, hyphae straight to substraight, appressoria alternate and about } 2 \% \\
\text { unilateral, straight to curved, antrorse to subantrorse, } \\
\text { head cells subglobose to ellipsoidal, entire to slightly angular, phialides mixed with appressoria, } \\
\text { mycelial setae grouped around perithecia, simple, straight, acute, obtuse to dentate at the tip }\end{array}$ & Meliola meghalayensis \\
\hline & FLACOURTIACEAE & \\
\hline $\begin{array}{l}\text { Asteridiella } \\
3103.3220\end{array}$ & $\begin{array}{l}\text { Colonies amphigenous, mostly epiphyllous, subdense; hyphae straight to substraight; appressoria } \\
\text { alternate, about } 5 \% \text { opposite, antrorse to spreading, head cells ovate to obovate, entire to slightly } \\
\text { angular; phialides mixed with appressoria, perithecial wall cells mammiform }\end{array}$ & Asteridiella homaligena \\
\hline 3101.4220 & $\begin{array}{l}\text { Colonies epiphyllous, scattered, crustose, mostlynear the leaf margins; hyphae substraight to crooked; } \\
\text { appressoria alternate, unilateral, up to } 1 \% \text { opposite, antrorse, subantrorse to retrorse, head cells } \\
\text { ovate, oblong to cylindrical, straight to curved, entire to angular; phialides mixed with appressoria; } \\
\text { perithecial wall cells conoid to mammiform, straight to curved }\end{array}$ & $\begin{array}{l}\text { Asteridiella scolopiae var. } \\
\text { indica }\end{array}$ \\
\hline \multirow[t]{2}{*}{$\begin{array}{l}\text { Meliola } \\
311 \frac{1}{2} 1.5324\end{array}$} & $\begin{array}{l}\text { Colonies hypophyllous, subdense to dense; hyphae substraight; appressoria alternate to unilateral, } \\
1 \% \text { opposite, antrorse to subantrorse, head cells ovate, oblong, globose, entire; phialides mixed with } \\
\text { appressoria; mycelial setae are of two types: setae on mycelia are scattered, simple, straight, acute } \\
\text { to obtuse at the tip, up to } 1200 \mu \mathrm{m} \text { long and setae grouped around perithecia are simple, straight to } \\
\text { curved, uncinate }\end{array}$ & Meliola arippaensis sp. nov. \\
\hline & GENTIANACEAE & \\
\hline \multirow[t]{2}{*}{ Meliola 3111.4233} & $\begin{array}{l}\text { Colonies hypophyllous, dense, hyphae straight to substraight, appressoria alternate to unilateral, } \\
\text { antrorse, subantrorse to retrorse, straight to curved, head cells ovate, oblong, entire to angular, } \\
\text { phialides mixed with appressoria, mycelial setae simple, straight, acute at the tip }\end{array}$ & Meliola exacigena \\
\hline & HIPPOCRATACEAE & \\
\hline \multirow[t]{2}{*}{$\begin{array}{l}\text { Meliola } \\
31 \frac{1}{2} 1.4233\end{array}$} & $\begin{array}{l}\text { Colonies amphigenous, subdense, hyphae straight to sub straight, appressoria mostly alternate, up to } \\
1 \% \text { opposite, unilateral , antrorse to sub-antrorse, straight to slightly curved, head cells globose, ovate, } \\
\text { oblong, entire to slightly angular, straight, phialides mixed with appressoria, mycelial setae numerous, } \\
\text { simple, straight, curved to arcuate, acute to obtuse at the tip }\end{array}$ & Meliola salaciicola \\
\hline & LAMIACEAE & \\
\hline \multirow[t]{2}{*}{$\begin{array}{l}\text { Amazonia } \\
3101.3220\end{array}$} & $\begin{array}{l}\text { Colonies epiphyllous, dense; hyphae substraight to flexuous; appressoria alternate to unilateral, } \\
\text { straight to curved, antrorse to closely antrorse and often appressed to the hyphae; head cells ovate to } \\
\text { globose, entire; phialides born on a separate mycelial branches }\end{array}$ & Amazonia dikesinghii \\
\hline & LAURACEAE & \\
\hline $\begin{array}{l}\text { Asterediella } \\
3101.4220\end{array}$ & $\begin{array}{l}\text { Colonies amphigenous, mostly hypophyllous, dense, velvety, } \\
\text { Hyphae straight to substraight, } \\
\text { Appressoria alternate, antrorse, subantrorse to rarely retrorse, straight to rarely curved, } \\
\text { head cells ovate, oblong, rarely rounded to slightly attenuated at the apex, often truncate at the apex, } \\
\text { entire, rarely angular, }\end{array}$ & Asterediella persiicola \\
\hline $\begin{array}{l}\text { Meliola } \\
311 / 21.4333\end{array}$ & $\begin{array}{l}\text { Colonies hypophyllous, sub-dense, velvety; hyphae straight to undulate; appressoria alternate to } \\
\text { unilateral, antrorse to sub-antrorse, straight to curved, head cells globose, ovate, slightly angular, } \\
\text { entire; phialides mixed with appressoria; mycelial setae numerous, scattered, straight, very few } \\
\text { uncinate, simple, acute to obtuse at the tip }\end{array}$ & Meliola palakkadensis \\
\hline \multirow[t]{2}{*}{$31 \frac{1}{3} 3.4323$} & $\begin{array}{l}\text { Colonies hypophyllous, subdense; hyphae straight to substraight; appressoria alternate, about } 40 \% \\
\text { opposite, antrorse to subantrorse, head cells globose, entire; phialides mixed with appressoria; } \\
\text { mycelial setae numerous, scattered, simple, straight, obtuse to dentate at the tip }\end{array}$ & $\begin{array}{l}\text { Meliola kakachiana var. } \\
\text { poochiparensis }\end{array}$ \\
\hline & LINACEAE & \\
\hline \multirow[t]{2}{*}{$\begin{array}{l}\text { Meliola } \\
3113.4224\end{array}$} & $\begin{array}{l}\text { Colonies epiphyllous, subdense to dense, velvety; hyphae straight to substraight; appressoria } \\
\text { opposite, about } 2 \% \text { alternate to unilateral, straight to curved, antrorse to spreading; head cells ovate } \\
\text { to oblong, entire, broadly rounded at the apex; phialides mixed with appressoria; mycelial setae } \\
\text { scattered to grouped around perithecia, simple, straight, acute to obtuse at the tip; }\end{array}$ & Meliola hugoniae \\
\hline & LORANTHACEAE & \\
\hline $\begin{array}{l}\text { Irenopsis } \\
3401.4220\end{array}$ & $\begin{array}{l}\text { Colonies epiphyllous, dense, velvety; hyphae substraight, flexuous to crooked; appressoria alternate } \\
\text { to unilateral, antrorse, subantrorse to retrorse, head cells mostly entire, ovate, clavate to cylindrical, } \\
\text { rarely angular to sublobate; phialides mixed with appressoria; perithecial setae } 2-10 \text { in number, } \\
\text { simple, straight to uncinate at the apical portion, acute to obtuse at the tip }\end{array}$ & Irenopsis loranthicola \\
\hline
\end{tabular}




\begin{tabular}{|c|c|c|}
\hline & MAGNOLIACEAE & \\
\hline $\begin{array}{l}\text { Asteridiella } \\
3101.2220\end{array}$ & $\begin{array}{l}\text { Colonies epiphyllous, thin; hyphae substraight; appressoria alternate, antrorse, mostly straight, head } \\
\text { cells ovate, oblong, angular to sublobate, phialides mixed with appressoria }\end{array}$ & Asteridiella micheliae \\
\hline \multirow[t]{2}{*}{ Meliola 3113.4222} & $\begin{array}{l}\text { Colonies epiphyllous, dense; hyphae substraight to flexuous to slightly crooked; appressoria alternate, } \\
\text { opposite to unilateral, antrorse to subantrorse, straight to variously curved, head cells ovate, oblong to } \\
\text { cylindrical, entire, angular, crenately lobate to sublobate; phialides mixed with appressoria; mycelial } \\
\text { setae grouped around perithecia, simple, straight, acute at the tip }\end{array}$ & Meliola cariappae sp. nov. \\
\hline & MALPHIGIACEAE & \\
\hline \multirow[t]{2}{*}{$\begin{array}{l}\text { Irenopsis } \\
3403.5320\end{array}$} & $\begin{array}{l}\text { Colonies amphigenous, subdense; hyphae straight to substraight; appressoria alternate, unilateral to } \\
3-4 \% \text { opposite, antrorse to subantrorse, head cells ovate, entire, mostly angular to rarely sublobate; } \\
\text { phialides mixed with appressoria; perithecial setae simple, straight, obtuse at the tip }\end{array}$ & $\begin{array}{l}\text { Irenopsis hiptages var. indica } \\
\text { var. nov. }\end{array}$ \\
\hline & MALVACEAE & \\
\hline $\begin{array}{l}\text { Irenopsis } \\
3401.3220\end{array}$ & $\begin{array}{l}\text { Colonies amphigenous, thin, hyphae sub straight to flexuous, appressoria alternate to unilateral, } \\
\text { antrorse, sub-antrorse to retrorse, straight to curved, head cells globose, ovate, entire to sublobate, } \\
\text { phialides mixed with appressoria, }\end{array}$ & Irenopsis sidae var. abutili \\
\hline 3403.3220 & $\begin{array}{l}\text { Colonies epiphyllous, thin; hyphae flexuous; appressoria alternate, } 5 \% \text { unilateral, antrorse to } \\
\text { spreading, straight to variously curved, head cells ovate to globose, entire, subangular to sublobate, } \\
\text { truncate; phialides mixed with appressoria; perithecial setae 10-16 in number, simple, straight, } \\
\text { smooth, obtuse at the tip }\end{array}$ & Irenopsis pavoniae \\
\hline \multirow[t]{2}{*}{$\begin{array}{l}\text { Meliola } \\
3111.3221\end{array}$} & $\begin{array}{l}\text { Colonies epiphyllous, dense; hyphae substraight to flexuous; appressoria alternate, unilateral, } \\
\text { antrorse, head cells globose, ovate, entire to slightly angular; phialides mixed with appressoria; } \\
\text { mycelial setae numerous, scattered to grouped around perithecia, simple, straight to curved, acute to } \\
\text { obtuse at the tip }\end{array}$ & Meliola mutabilidis sp. nov. \\
\hline & MELIACEAE & \\
\hline $\begin{array}{l}\text { Irenopsis } \\
3401.4220\end{array}$ & $\begin{array}{l}\text { Colonies epiphyllous, subdense, scattered; hyphae straight to flexuous, appressoria alternate, } \\
\text { unilateral, antrorse to subantrorse, head cells globose, angular, sublobate to deeply lobate phialides } \\
\text { mixed with appressoria, perithecial setae } 0-5 \text { in number, straight, simple, obtuse at the apex }\end{array}$ & Irenopsis trichiliae \\
\hline $\begin{array}{l}\text { Meliola } \\
31 \frac{1}{3} 2.3322\end{array}$ & $\begin{array}{l}\text { Colonies amphigenous, mostly hypophyllous, dense, velvety; hyphae straight to substraight, } \\
\text { appressoria opposite, rarely solitary, straight to curved, antrorse, subantrorse to retrorse, head cells } \\
\text { ovate, oblong, cylindrical, entire, angular, sublobate to often bilobed, phialides mixed with appressoria, } \\
\text { mycelial setae many, grouped around perithecia, simple, sigmoid, curved to uncinate at the apical } \\
\text { portion, acute, obtuse to bifid at the tip, }\end{array}$ & Meliola sairandhriana \\
\hline 3111.3232 & $\begin{array}{l}\text { Colonies epiphyllous, thin, velvety; hyphae straight to substraight; appressoria alternate, straight } \\
\text { to curved, antrorse to spreading; head cells straight to curved, ovate, globose, cylindrical, entire; } \\
\text { phialides mixed with appressoria; mycelial setae scattered to grouped around perithecia, simple, } \\
\text { straight, acute to obtuse at the tip }\end{array}$ & Meliola cipadessae \\
\hline 3122.3221 & $\begin{array}{l}\text { Colonies epipyllous, subdense, velvety; hyphae straight; appressoria opposite, antrorse, to } \\
\text { subantrorse to spreading; head cells ovate, cylindrical, slightly attenuated and broadly rounded at } \\
\text { the apex, entire. phialides mixed with appressoria, mycelial setae grouped around perithecia, simple, } \\
\text { uncinate to slightly coiled, acute at the tip }\end{array}$ & Meliola vazhachalensis \\
\hline 3112.4223 & $\begin{array}{l}\text { Colonies epiphyllous, subdense; hyphae straight to substraight; appressoria arranged closely by } \\
\text { leaving an intermittent gap, part of the mycelium literally devoid of appressoria, opposite, antrorse to } \\
\text { subantrorse, closely arranged on the hyphae, head cells oblong, ovate, entire, angular to sublobate; } \\
\text { phialides mixed with appressoria; mycelial setae numerous, scattered, simple, straight, acute to obtuse } \\
\text { at the tip }\end{array}$ & Meliola arkevermae \\
\hline $31 \frac{1}{3} 3.3231$ & $\begin{array}{l}\text { Colonies epiphyllous, dense, velvety; hyphae substraight to crooked; appressoria alternate, unilateral, } \\
\text { opposite, antrorse, subantrorse to retrorse, } \\
\text { head cells globose, subglobose, entire to rarely truncate; phialides mixed with appressoria; mycelial } \\
\text { setae scattered, simple, straight, acute, 2-3-times dentate at the tip }\end{array}$ & Meliola dysoxyligena \\
\hline \multirow[t]{2}{*}{$31 \frac{1}{3} 1.4222$} & $\begin{array}{l}\text { Colonies amphigenous, mostly epiphyllous; hyphae straight to substraight; appressoria alternate } \\
\text { to unilateral, antrorse to subantrorse, head cells ovate, globose, entire; phialides mixed with } \\
\text { appressoria; mycelial setae numerous, scattered, straight, dentate, cristate, bifid to obtuse at the tip }\end{array}$ & Meliola garugae \\
\hline & MORACEAE & \\
\hline $\begin{array}{l}\text { Asteridiella } \\
3101.3220\end{array}$ & $\begin{array}{l}\text { Colonies epiphyllous, dense, hyphae straight, substraight to flexuous, appressoria alternate to } \\
\text { unilateral, straight to slightly curved, antrorse to subantrorse, rarely retrorse, head cells straight to } \\
\text { slightly curved, globose, ovate, oblong, entire to rarely angular, phialides mixed with appressoria }\end{array}$ & Asteridiella ficicola \\
\hline $\begin{array}{l}\text { Meliola } \\
3111.4233\end{array}$ & $\begin{array}{l}\text { Colonies amphigenous, mostly hypophyllous, dense, velvety, hyphae straight to substraight, } \\
\text { appressoria alternate to unilateral, distantly placed, antrorse, subantrorse to rarely retrorse, head cells } \\
\text { ovate, globose, entire, straight to curved, phialides mixed with appressoria, mycelial setae scattered, } \\
\text { simple, straight, acute at the tip }\end{array}$ & Meliola strebli \\
\hline
\end{tabular}




\begin{tabular}{|c|c|c|}
\hline $31 \frac{1}{3} 3.4223$ & $\begin{array}{l}\text { Colonies epiphyllous, thin to subdense; hyphae straight; appressoria opposite, alternate, antrorse to } \\
\text { subantrorse, head cells oblong, ovate, entire to slightly angular; phialides mixed with appressoria; } \\
\text { mycelial setae numerous, simple, acute, obtuse to dentate at the tip }\end{array}$ & Meliola kannurensis \\
\hline & MYRISTICACEAE & \\
\hline $\begin{array}{l}\text { Meliola } \\
31 \frac{1}{3} 3.5324\end{array}$ & $\begin{array}{l}\text { Colonies epiphyllous, scattered, thin; hyphae straight to substraight; appressoria opposite (48\%), } \\
\text { alternate, unilateral, antrorse to sub antrorse; head cells globose, ovate, rarely truncate, entire; } \\
\text { phialides mixed with appressoria, mycelial setae simple, straight to slightly curved, acute to 1-3- times } \\
\text { dentate at the tip }\end{array}$ & Meliola manoharacharyi \\
\hline 3111.4223 & $\begin{array}{l}\text { Colonies epiphyllous, thin; hyphae straight to substraight; appressoria alternate to unilateral, antrorse } \\
\text { to subantrorse, head cells ovate to oblong, entire; phialides mixed with appressoria; mycelial setae } \\
\text { grouped around perithecia, simple, straight, acute to obtuse at the tip }\end{array}$ & Meliola knemae \\
\hline \multirow[t]{2}{*}{$31 \frac{1}{3} 2.4221$} & $\begin{array}{l}\text { Colonies amphigenous, thin, strongly appressed to the host surface, } \\
\text { Hyphae straight to substraight, } \\
\text { Appressoria opposite, antrorse to subantrorse, } \\
\text { head cells narrowly ovate, attenuated and broadly rounded towards the apex, entire, } \\
\text { Phialides mixed with appressoria, } \\
\text { Mycelial setae scattered, simple, straight }\end{array}$ & Meliola myristicola \\
\hline & MYRSINACEAE & \\
\hline 3113.5223 & $\begin{array}{l}\text { Colonies hypophyllous, dense, velvety; hyphae substraight to crooked; appressoria alternate to } \\
\text { opposite, straight to curved, antrorse to spreading, retrorse; head cells ovate, globose to subglobose, } \\
\text { cylindrical, clavate, entire, phialides mixed with appressoria, mycelial setae fairly numerous, scattered } \\
\text { to grouped around perithecia, straight to curved but not uncinate, acute to obtuse at the tip }\end{array}$ & Meliola rapaneae \\
\hline \multirow[t]{2}{*}{3113.5221} & $\begin{array}{l}\text { Colonies hypophyllous, subdense to dense, Hyphae substraight; appressoria alternate, up to } 30 \% \\
\text { opposite to unilateral, antrorse to subantrorse, head cells ovate, globose, entire, phialides mixed with } \\
\text { appressoria; mycelial setae simple, straight, acute to obtuse at the tip, }\end{array}$ & Meliola ardisiigena \\
\hline & MYRTACEAE & \\
\hline $\begin{array}{l}\text { Asteridiella } \\
3101.4230\end{array}$ & $\begin{array}{l}\text { Colonies amphigenous, subdense, hyphae substraight to flexuous, appressoria alternate to unilateral, } \\
\text { antrorse to subantrorse, straight to slightly curved, head cells oblong, ovate, globose, entire, phialides } \\
\text { mixed with appressoria, }\end{array}$ & Asteridiella brahmagiriensis \\
\hline \multirow[t]{2}{*}{$\begin{array}{l}\text { Meliola } \\
31 \frac{1}{3} 1.5324\end{array}$} & $\begin{array}{l}\text { Colonies amphigenous, sub-dense, hyphae straight to sub-straight, appressoria alternate, unilateral, } \\
\text { antrorse to retrorse, straight to curved, head cells oblong, ovate, curved, entire to angular, phialides } \\
\text { mixed with appressoria, mycelial setae straight, acute, obtuse, dentate to furcate at the tip }\end{array}$ & Meliola kukkeensis \\
\hline & OLACACEAE & \\
\hline $\begin{array}{l}\text { Asteridiella } \\
3111.4220\end{array}$ & $\ldots$ & Asteridiella anacolosae \\
\hline Meliola 3113.5333 & $\begin{array}{l}\text { Colonies amphigenous, mostly hypophyllous, dense, velvety; hyphae flexuous to undulate; appressoria } \\
\text { alternate, opposite to unilateral, antrorse to subantrorse, rarely retrorse, head cells oblong to } \\
\text { cylindrical, straight to flexuously curved, entire; phialides mixed with appressoria; mycelial setae } \\
\text { straight to curved, scattered, acute at the tip }\end{array}$ & Meliola strombosiigena \\
\hline \multirow[t]{2}{*}{3111.3223} & $\begin{array}{l}\text { Colonies epiphyllous, dense; hyphae straight; appressoria alternate, antrorse; head cells ovate, oblong, } \\
\text { entire, broadly rounded to truncate to attenuate at the apex; phialides mixed with appressoria; } \\
\text { mycelial setae scattered, simple, straight, acute at the tip }\end{array}$ & $\begin{array}{l}\text { Meliola strombosiicola nom. } \\
\text { nov. }\end{array}$ \\
\hline & OLEACEAE & \\
\hline \multirow[t]{2}{*}{$\begin{array}{l}\text { Meliola } \\
3111.4212\end{array}$} & $\begin{array}{l}\text { Colonies epiphyllous, thin; hyphae flexuous; appressoria alternate, straight to curved, antrorse to } \\
\text { retrorse, head cells oblong, ovate, rarely globose, entire; phialides mixed with appressoria; mycelial } \\
\text { setae scattered, simple, obtuse at the tip }\end{array}$ & $\begin{array}{l}\text { Meliola daviesii var. } \\
\text { kodaikalensis }\end{array}$ \\
\hline & PITTOSPORACEAE & \\
\hline \multirow[t]{2}{*}{$\begin{array}{l}\text { Asteridiella } \\
3101.4220 \\
\end{array}$} & $\cdots$ & Asterediella pittosporacearum \\
\hline & RANANCULACEAE & \\
\hline \multirow[t]{2}{*}{ Meliola 3111.3222} & $\begin{array}{l}\text { Colonies epiphyllous, dense; hyphae substraight to flexuous; appressoria alternate to unilateral } \\
\text { antrorse, subantrorse to retrorse, head cells, ovate, entire, angular to sublobate; phialides mixed with } \\
\text { appressoria; mycelial setae scattered, simple, straight, obtuse at the tip }\end{array}$ & Meliola knowltoniae \\
\hline & RHAMNACEAE & \\
\hline $\begin{array}{l}\text { Meliola } \\
311 / 31.3222\end{array}$ & $\begin{array}{l}\text { Colonies epiphyllous, thin; hyphae straight to substraight; appressoria mostly alternate, unilateral, } \\
\text { antrorse to subantrorse; head cells ovate, globose, entire, angular to slightly lobate; phialides mixed } \\
\text { with appressoria; mycelial setae scattered, simple, straight, obtuse to dentate at the tip }\end{array}$ & Meliola gouaniae var. indica \\
\hline
\end{tabular}




\begin{tabular}{|c|c|c|}
\hline $\begin{array}{l}\text { Asteridiella } \\
3101.3220\end{array}$ & $\begin{array}{l}\text { Colonies amphigenous, mostly epiphyllous, thin; hyphae straight, substraight to slightly undulate; } \\
\text { appressoria alternate, unilateral, antrorse to subantrorse; head cells globose, ovate, oblong, entire, } \\
\text { angular to slightly lobate; phialides mixed with appressoria }\end{array}$ & Asteridiella emciciana \\
\hline $\begin{array}{l}\text { Meliola } \\
3111.3222\end{array}$ & $\begin{array}{l}\text { Colonies amphigenous, dense, velvety; hyphae substraight to slightly undulate; appressoria alternate } \\
\text { to } 5 \% \text { unilateral, antrorse to sub antrorse; head cells globose, subglobose to oblong; phialides mixed } \\
\text { with appressoria mycelial setae scattered, grouped around perithecia straight, simple, obtuse at the tip }\end{array}$ & Meliola gouaniicola \\
\hline 3111.4223 & $\begin{array}{l}\text { Colonies hypophyllous, subdense to dense; hyphae flexuous to crooked; appressoria alternate, } \\
\text { antrorse, subantrorse to retrorse, head cells oblong, ovate, entire; phialides mixed with appressoria; } \\
\text { mycelial setae scattered, simple, straight }\end{array}$ & Meliola colubrinicola \\
\hline \multirow[t]{2}{*}{3111.4232} & $\begin{array}{l}\text { Colonies amphigenous, thin; hyphae flexuous; appressoria alternate, straight to curved, antrorse to } \\
\text { retrorse, head cells ovate, globose, truncate to attenuated at the apex, sublobate; phialides on borne } \\
\text { on a separate mycelial branch, alternate; mycelial setae grouped around perithecia, simple, straight, } \\
\text { acute to obtuse at the tip }\end{array}$ & Meliola hoveniae \\
\hline & RUBIACEAE & \\
\hline $\begin{array}{l}\text { Asteridiella } \\
3101.4220\end{array}$ & $\begin{array}{l}\text { Colonies amphigenous, subdense, hyphae straight to substraight, appressoria alternate, unilateral, } \\
1 \% \text { opposite, antrorse, to subantrorse, straight, head cells ovate, oblong, globose, entire to slightly } \\
\text { angular, phialides mixed with appressoria, }\end{array}$ & Asteridiella ixorae \\
\hline $\begin{array}{l}\text { Irenopsis } \\
3401.4220\end{array}$ & $\begin{array}{l}\text { Colonies epiphyllous, thin; hyphae substraight to flexuous; appressoria alternate, } 1 \% \text { opposite to } \\
\text { unilateral, antrorse to subantrorse, head cells ovate, oblong, straight to curved, entire, angular to } \\
\text { rarely slightly lobate; phialides mixed with appressoria; perithecial setae } 5-8 \text {, straight to slightly } \\
\text { curved, upright, smooth walled, broadly rounded at the tip }\end{array}$ & Irenopsis xeromphidis \\
\hline $\begin{array}{l}\text { Meliola } \\
3111.3223\end{array}$ & $\begin{array}{l}\text { Colonies amphigenous, thin, hyphae straight to substraight, appressoria alternate to unilateral, } \\
\text { antrorse to subantrorse, straight to curved, head cells ovate, oblong, entire to slightly angular, } \\
\text { phialides mixed with appressoria, mycelial setae simple, straight, acute at the tip }\end{array}$ & Meliola canthiigena \\
\hline 3111.4221 & $\begin{array}{l}\text { Colonies amphigenous, thin; appressoria alternate, antrorse to subantrorse, straight to curved, head } \\
\text { cells cylindrical, ovate, angular to sublobate; phialides borne on a separate mycelial branch; mycelial } \\
\text { setae numerous, grouped around perithecia, simple, straight, obtuse at the tip }\end{array}$ & Meliola luculiae \\
\hline \multirow[t]{2}{*}{3111.3221} & $\begin{array}{l}\text { Colonies amphigenous rarely hypophyllous, sub-dense; hyphae sub straight; appressoria alternate to } \\
\text { unilateral, antrorse, spreading, straight, head cells globose, ovate, straight, entire; phialides mixed with } \\
\text { appressoria; mycelial setae numerous, simple, straight to slightly curved, acute to obtuse at the tip }\end{array}$ & $\begin{array}{l}\text { Meliola kanniyakumariana var. } \\
\text { brahmagiriense }\end{array}$ \\
\hline & RUTACEAE & \\
\hline $\begin{array}{l}\text { Asteridiella } \\
3101.4330\end{array}$ & $\begin{array}{l}\text { Colonies amphigenous, dense, velvety; hyphae straight; appressoria alternate, unilateral, about } 10 \% \\
\text { opposite, antrorse to subantrorse, rarely retrorse, head cells ovate, globose, entire; phialides mixed } \\
\text { with appressoria; perithecial wall cells mammiform to conoid }\end{array}$ & Asteridiella toddaliae \\
\hline Meliola 3111.2222 & $\begin{array}{l}\text { Colonies epiphyllous, thin, hyphae straight to substraight, appressoria alternate to unilateral, antrorse, } \\
\text { head cells oblong, sublobate, angular, straight to curved, phialides mixed with appressoria, } \\
\text { mycelial setae scattered, simple, straight, acute at the tip, }\end{array}$ & Meliola luvungicola \\
\hline 3111.4221 & $\begin{array}{l}\text { Colonies amphigenous, dense, velvety; hyphae straight; appressoria alternate, rarely unilateral, often } \\
\text { crowded, antrorse, straight; head cells ovate, angular, sinuately lobate to deeply lobate; phialides } \\
\text { mixed with appressoria; mycelial setae straight to slightly curved, scattered to grouped around } \\
\text { perithecia, obtuse at the tip }\end{array}$ & Meliola vatsavayae \\
\hline \multirow[t]{2}{*}{$31 \frac{1}{3} 3.3221$} & $\begin{array}{l}\text { Colonies amphigenous, dense, velvety; hyphae straight, flexuous; appressoria mostly opposite, rarely } \\
\text { unilateral, antrorse to subantrorse, head cells ovate, oblong, rarely globose, straight to curved, entire, } \\
\text { often sinuate, truncate at the apex; phialides mixed with appressoria, opposite, alternate to unilateral; } \\
\text { mycelial setae simple, straight to uncinate at the apical portion, acute, obtuse to } 2-3 \text {-times dentate at } \\
\text { the tip }\end{array}$ & Meliola clausenigena \\
\hline & SANTALACEAE & \\
\hline \multirow[t]{2}{*}{$\begin{array}{l}\text { Meliola } \\
3113.4222\end{array}$} & $\begin{array}{l}\text { Colonies amphigenous, mostly epiphyllus dense; hyphae straight to substraight; appressoria opposite } \\
\text { to alternate, antrorse; head cells ovate to globose, entire; phialides mixed with appressoria; mycelial } \\
\text { setae scattered, straight, simple, obtuse at the tip }\end{array}$ & Meliola mahamulkarii \\
\hline & SAPOTACEAE & \\
\hline \multirow[t]{2}{*}{$\begin{array}{l}\text { Amazonia } \\
3101.4230\end{array}$} & $\begin{array}{l}\text { Colonies hypophyllous, crustose; hyphae substraight; appressoria alternate to unilataral, antrorse, } \\
\text { straight to slightly curved, head cells globose, ovate, entire; phialides few, mixed with appressoria }\end{array}$ & Amazonia palaquii \\
\hline & SAPINDACEAE & \\
\hline $\begin{array}{l}\text { Ectendomeliola } \\
31 \frac{1}{3} 1.4222\end{array}$ & $\begin{array}{l}\text { Colonies hypophyllous, subdense, crustose; hyphae substraight to crooked, branching irregular at } \\
\text { acute angles, form irregular mycelial net, loosely to closely reticulate, cells and endophytic; phialides } \\
\text { few, mixed with appressoria; mycelial setae numerous, simple, straight to uncinate, acute, obtuse, } \\
\text { dentate to furcate at the tip }\end{array}$ & Ectendomeliola otonephelii \\
\hline
\end{tabular}




\begin{tabular}{|c|c|c|}
\hline $\begin{array}{l}\text { Meliola } \\
31 \frac{1}{3} 3.3222\end{array}$ & $\begin{array}{l}\text { Colonies hypophyllous, dense, hyphae straight to substraight, appressoria opposite, alternate, } \\
\text { antrorse, subantrorse to retrorse, head cells ovate, globose, entire to angular, straight to curved, } \\
\text { phialides few, mixed with appressoria, mycelial setae, simple, straight, acute, dentate to furcate at the } \\
\text { tip }\end{array}$ & Meliola filicii var. indica \\
\hline \multirow[t]{2}{*}{$312 \frac{2}{3} 1.4222$} & $\begin{array}{l}\text { Colonies epiphyllous, subdense to dense; hyphae straight to substraight; appressoria alternate } \\
\text { to unilateral, antrorse to subantrorse, head cells ovate, entire; phialides numerous, mixed with } \\
\text { appressoria; mycelial setae numerous, scattered, simple, straight to uncinate, up to } 320 \mu \mathrm{m} \text { long, } \\
\text { obtuse , 1-3- dentate but predominantly cristate at the tip. }\end{array}$ & Meliola harpullicola sp. nov. \\
\hline & SIMAROUBACEAE & \\
\hline \multirow[t]{2}{*}{$\begin{array}{l}\text { Meliola } \\
31 \frac{1}{3} 1.4222\end{array}$} & $\begin{array}{l}\text { Colonies hypophyllous, thin, hyphae crooked, appressoria alternate to unilateral, straight to curved, } \\
\text { antrorse, subantrorse to retrorse, head cells ovate, globose, truncate to slightly lobate, phialides mixed } \\
\text { with appressoria, mycelial setae scattered, simple, straight, acute, obtuse to } 2-5 \text { dentate at the tip }\end{array}$ & Meliola ailanthicola \\
\hline & SOLANACEAE & \\
\hline $\begin{array}{l}\text { Asteridiella } \\
3101.4230\end{array}$ & $\begin{array}{l}\text { Colonies mostly epiphyllous, scattered, subdense, velvety; hyphae flexuous; appressoria alternate, } \\
\text { straight to curved, subantrorse to closely antrorse, head cells globose, sub-lobate, slightly angular, } \\
\text { entire; phialides borne on a separate mycelial branch; perithecial cells larviform, mammiform }\end{array}$ & $\begin{array}{l}\text { Asteridiella solani var. } \\
\text { kodaikanalensis }\end{array}$ \\
\hline \multirow[t]{2}{*}{3101.6320} & $\begin{array}{l}\text { Colonies epiphyllous, thin; hyphae flexuous; appressoria alternate, alternate to rarely opposite, } \\
\text { antrorse, straight to curved' head cells ovate to cylindrical, sometimes reniform entire; phialides borne } \\
\text { on a separate mycelial branch; perithecial wall cells projected }\end{array}$ & $\begin{array}{l}\text { Asteridiella winteri var. } \\
\text { macrospora }\end{array}$ \\
\hline & STERCULIACEAE & \\
\hline $\begin{array}{l}\text { Irenopsis } \\
3401.4220\end{array}$ & $\begin{array}{l}\text { Colonies amphigenous, subdense, hyphae substraight to undulate, appressoria alternate, unilateral, } \\
\text { antrorse, subantrorse to retrorse, straight to curved, head cells globose, ovate, oblong, entire to } \\
\text { angular, phialides mixed with appressoria, perithecial setae } 4-10 \text { in number, simple, straight, pale } \\
\text { brown, septate, straight to uncinate at the apical part, obtuse at the tip, }\end{array}$ & Irenopsis kleinhoviae \\
\hline 3401.3220 & $\begin{array}{l}\text { Colonies amphigenous, thin, Hyphae substraight to flexuous; apressoria alternate, straight to curved, } \\
\text { antrorse, subantrorse to retrorse, head cells globose, ovate, entire angular to sublobate; phialides } \\
\text { mixed with appressoria, Perithecial setae } 2-6 \text {, simple, straight, obtuse at the tip }\end{array}$ & Irenopsis pterigotae \\
\hline $\begin{array}{l}\text { Meliola } \\
31 \frac{1}{2} 2.3222\end{array}$ & $\begin{array}{l}\text { Colonies epiphyllous, dense, velvety; hyphae straight to substraight; appressoria alternate, antrorse to } \\
\text { subantrorse; head cells ovate, globose, oblong, mostly entire, often angular to rarely slightly lobate; } \\
\text { phialides mixed with appressoria; mycelial setae scattered to grouped around perithecia, simple, } \\
\text { straight, flexuous to rarely curved to very few uncinate, obtuse at the tip }\end{array}$ & Meliola pterigotae \\
\hline \multirow[t]{2}{*}{3111.4222} & $\begin{array}{l}\text { Colonies epiphyllous, thin; hyphae straight to substraight;appressoria mostly alternate, unilateral, } \\
\text { antrorse to subantrorse; head cells ovate, globose, entire, angular to slightly lobate; phialides borne } \\
\text { on a separate mycelia branch; mycelial setae few, simple, straight, acute at the tip }\end{array}$ & Meliola sterculicola \\
\hline & SYMPLOCACEAE & \\
\hline $\begin{array}{l}\text { Asteridiella } \\
2101.4230\end{array}$ & $\begin{array}{l}\text { Colonies amphigenous, mostly epiphyllous, dense, hyphae straight to substraight, appressoria } \\
\text { alternate, unilateral, straight to often slightly curved, antrorse to subantrorse, stalk cells mostly } \\
\text { unicellular, rarely } 1 \text {-septate, head cells mostly straight, often curved, oblong, ovate, clavate, mostly } \\
\text { entire, often angular, } \\
\text { rarely sublobate }\end{array}$ & Asteridiella shenbaganurensis \\
\hline 3101.4220 & $\begin{array}{l}\text { Colonies amphigenous, mostly epiphyllous, dense, hyphae straight to substraight, appressoria } \\
\text { alternate, unilateral, straight, antrorse, head cells mostly straight, globose, ovate, entire, phialides } \\
\text { mixed with appressoria, }\end{array}$ & Asteridiella kodaikanalensis \\
\hline \multirow[t]{2}{*}{3101.3230} & $\begin{array}{l}\text { Colonies amphigenous, subdense, Hyphae straight to substraight, Appressoria alternate to unilateral, } \\
\text { antrorse to subantrorse, head cells globose to ovate, entire, Phialides mixed with appressoria, } \\
\text { perithecial wall cells conoid to mammiform, up to } 50 \mu \mathrm{m} \text { long; }\end{array}$ & $\begin{array}{l}\text { Asteridiella symploci- } \\
\text { microphyllae }\end{array}$ \\
\hline & TYPHACEAE & \\
\hline $\begin{array}{l}\text { Meliola } \\
311 / 23.4223\end{array}$ & $\begin{array}{l}\text { Colonies mostly epiphyllous, rarely hypophyllous subdense to dense, confluent and often cover } \\
\text { entire upper surface of the leaves. Hyphae straight to substraight, Appressoria alternate, opposite to } \\
\text { unilateral, antrorse to subantrorse, head cells globose to ovate, entire, straight to recurved, } \\
\text { Phialides mixed with appressoria, alternate to opposite, ampulliform, Mycelial setae scattered, simple, } \\
\text { straight to curved, often uncinate, acute, obtuse to rarely dentate at the tip, }\end{array}$ & Meliola typhae \\
\hline \multirow[t]{2}{*}{$\begin{array}{l}\text { Meliola } \\
3112.5323\end{array}$} & $\begin{array}{l}\text { Colonies epiphyllous, dense, crustose; hyphae straight; appressoria opposite, antrorse; head cells } \\
\text { globose, ovate, entire; phialides mixed with appressoria; mycelial setae simple, straight to slightly } \\
\text { curved, acute to obtuse at the tip }\end{array}$ & Meliola rachammae \\
\hline & VACCINIACEAE & \\
\hline $\begin{array}{l}\text { Meliola } \\
3111.3223\end{array}$ & $\begin{array}{l}\text { Colonies epiphyllous, dense, velvety, hyphae substraight to undulate, appressoria alternate, } \\
\text { antrorse to retrorse, straight to curved, closely placed, head cells ovate, globose to subglobose, } \\
\text { entire, phialides few in number, mixed with appressoria, mycelial setae numerous, grouped around } \\
\text { perithecia, simple, straight, slightly curved, acute to obtuse at the tip }\end{array}$ & Meliola shillongensis \\
\hline
\end{tabular}




\begin{tabular}{|c|c|c|}
\hline & VERBENACEAE & \\
\hline $\begin{array}{l}\text { Asteridiella } \\
3101.3220\end{array}$ & $\begin{array}{l}\text { Colonies epiphyllous, dense; hyphae flexuous to crooked, closely reticulate; appressoria alternate, } \\
\text { closely placed, antrorse to closely antrorse, often appressed to the hyphae, straight to curved, head } \\
\text { cells globose, clavate, distinctly angular to truncate, rarely rounded; phialides many, mixed with } \\
\text { appressoria, perithecial cells mammiform, broadly rounded at the apex }\end{array}$ & Asteridiella depokensis \\
\hline 3101.4330 & $\begin{array}{l}\text { Colonies epiphyllous, dense; hyphae flexuous to crooked, Appressoria alternate, antrorse, subantrorse, } \\
\text { retrorse, straight to variously curved, head cells ovate, oblong, globose, angular to variously sublobate; } \\
\text { phialides mixed with appressoria; perithecial wall cells conoid to mammiform }\end{array}$ & Asteridiella madikeriensis \\
\hline 3101.4320 & $\begin{array}{l}\text { Colonies epiphyllous, dense; hyphae straight, substraight to flexuous; appressoria alternate, antrorse } \\
\text { to subantrorse, straight to curved, head cells globose, ovate, clavate to cylindrical, mostly angular, few } \\
\text { sublobate, rarely entire, truncate; phialides many, apparently borne on a separate mycelial branch } \\
\text { but mixed with appressoria, mostly opposite, often unilateral, ampulliform; perithecial wall cells } \\
\text { mammiform to conoid, attenuated at tip }\end{array}$ & Asteridiella viticis-negundoi \\
\hline $\begin{array}{l}\text { Meliola } \\
3111.3221\end{array}$ & $\begin{array}{l}\text { Colonies epiphyllous, subdense to dense; hyphae substraight; appressoria alternate to unilateral, } \\
\text { antrorse to subantrorse, head cells globose to ovate, entire; phialides mixed with appressoria; mycelial } \\
\text { setae straight to curved, simple }\end{array}$ & Meliola cookeana \\
\hline \multirow[t]{2}{*}{3121.3221} & $\begin{array}{l}\text { Colonies epiphyllous, velvety; hyphae flexuous to crooked; appressoria alternate, unilateral, antrorse } \\
\text { to subantrorse, head cells globose, subglobose, entire tosublobate; phialides mixed with appressoria; } \\
\text { mycelial setae scattered, simple, straight, slightly curved to uncinate }\end{array}$ & Meliola premnigena \\
\hline & VITACEAE & \\
\hline $\begin{array}{l}\text { Meliola } \\
3113.3223\end{array}$ & $\begin{array}{l}\text { Colonies epiphyllous, scattered; hyphae straight to undulate; appressoria alternate to opposite, } \\
\text { antrorse to subantrorse, retrorse to spreading; head cells ovate, globose, entire; phialides mixed with } \\
\text { appressoria; mycelial setae straight, simple, acute to obtuse at the tip }\end{array}$ & Meliola bakeri \\
\hline \multirow[t]{2}{*}{3113.4233} & $\begin{array}{l}\text { Colonies epiphyllous, dense, velvety; hyphae straight to undulate; appressoria opposite, about } 20 \% \\
\text { alternate to unilateral, very closely placed, mostly antrorse, rarely spreading, straight to slightly } \\
\text { curved; head cells ovate to oblong, cylindrical, entire, slightly angular, often truncate at the apex; } \\
\text { phialides mixed with appressoria; mycelial setae grouped around perithecia, straight, simple, obtuse } \\
\text { to broadly rounded at the tip }\end{array}$ & Meliola cayratiae \\
\hline & ZINGIBERACEAE & \\
\hline $\begin{array}{c}\text { Asteridiella } \\
3101.4210\end{array}$ & $\begin{array}{l}\text { Colonies amphigenous, dense, subvelvety; hyphae substraight to slightly crooked; appressoria } \\
\text { alternate and unilateral, straight to curved, antrorse to spreading; head cells ovate, globose, angular to } \\
\text { sublobate; phialides mixed with appressoria; perithecial cells conoid to mammiform }\end{array}$ & Asteridiella amomi \\
\hline
\end{tabular}


Host-Parasite-Index

\begin{tabular}{|c|c|c|}
\hline 1. & Abrus pulchellus & Meliola abri \\
\hline 2. & Abutilon sp. & Irenopsis sidae var. abutili \\
\hline 3. & Aganope thyrsiflora & Meliola aganopes \\
\hline 4. & Aglaia minutiflora & Meliola sairandhriana \\
\hline 5. & Aglaia sp. & Meliola vazhachalensis \\
\hline 6. & Ailanthus malabarica & Meliola ailanthicola \\
\hline 7. & Alangium salvifolium & Meliola alangii var. salvifolii \\
\hline 8. & Amomum subulatum & Asteridiella amomi \\
\hline 9. & Anacolosa sp. & Asteridiella anacolosae \\
\hline 10. & Aporusa sp. & Meliola aporusae \\
\hline 11. & Aralia sp. & Meliola abdulkalamii \\
\hline 12. & Ardisia sp. & Meliola ardisiigena \\
\hline 13. & Aristolochia grandiflora & Meliola aristolochigena \\
\hline 14. & Aristolochia tagala & Meliola aristolochigena \\
\hline 15. & Bauhinia purpurea & $\begin{array}{l}\text { Meliola bauhiniicola var. } \\
\text { brevipoda }\end{array}$ \\
\hline 16. & Caesalpinia banduc & Meliola caesalpiniicola \\
\hline 17. & Calycopteris floribunda & Meliola calycopteridis sp. nov. \\
\hline 18. & Canavalia sp. & Meliola canavaliae \\
\hline 19. & Canthium sp. & Meliola canthiigena \\
\hline 20. & Castanopsis armata & Asteridiella phukanea \\
\hline 21. & Castanopsis armata & Meliola meghalayensis \\
\hline 22. & Cayratia pedata & Meliola cayratiae \\
\hline 23. & Cayrtia pedata & Meliola bakeri \\
\hline 24. & Cipadessa bacciferra & Meliola cipadessae \\
\hline 25. & Clausena sp. & Meliola clausenigena \\
\hline 26. & Clematis sp. & Meliola knowltoniae \\
\hline 27. & Colubrina travancorica & Meliola colubrinicola \\
\hline 28. & Croton caudatus & Asteridiella crotonis-caudati \\
\hline 29. & Cynanchum sp. & Meliola cynanchi \\
\hline 30. & Cyperus sp. & Meliola cyperacearum \\
\hline 31. & Derris sp. & Meliola abrupta \\
\hline 32. & Desmodium laxiflorum & $\begin{array}{l}\text { Meliola desmodii-laxiflori } \\
\text { Deight. var. indica }\end{array}$ \\
\hline 33. & Dioscorea sp. & Meliola dioscoreacearum \\
\hline 34. & Dioscorea sp. & Meliola dioscoregena \\
\hline 35. & Diospyros buxifolia & Meliola diospyri-buxifoliae \\
\hline 36. & Diospyrus ebenum & Meliola ebeni \\
\hline 37. & Drypetes elata & Meliola erumeliensis \\
\hline 38. & Erythrina variegata & Meliola erythrinae var. indica \\
\hline 39. & Dysoxylum sp. & Meliola dysoxyligena \\
\hline 40. & Elaeocarpus munronii & Amazonia elaeocarpi \\
\hline 41. & Elaeocarpus tuberculatus & Appendiculella elaeocarpi \\
\hline 42. & Eunymous sp. & Meliola euonymi \\
\hline 43. & $\begin{array}{l}\text { Euphorbia pulcherrima } \\
\text { (Poinsettia pulcherima) }\end{array}$ & Asteridiella chowrirae \\
\hline 44. & Exacum sp. & Meliola exacigena \\
\hline
\end{tabular}

\begin{tabular}{|c|c|c|}
\hline 45. & Ficus gibbosa & Meliola kannurensis \\
\hline 46. & Ficus microcarpa & Asteridiella ficicola \\
\hline 47. & Filicium decipiens & Meliola filicii var. indica \\
\hline 48. & Flacourtia sp. & Meliola arippaensis sp. nov. \\
\hline 49. & Garuga pinnata & Meliola garugae \\
\hline 50. & Gluta travancorica & Meliola gluticola \\
\hline 51. & Gouania sp. & Meliola gouaniae var. keralica \\
\hline 52. & Gouania sp. & Meliola gouaniicola \\
\hline 53. & Harpullia arborea & Meliola harpullicola sp. nov. \\
\hline 54. & Hibiscus mutabilis & Meliola mutabilidis sp. nov. \\
\hline 55. & Hiptage sp. & $\begin{array}{l}\text { Irenopsis hiptages var. indica } \\
\text { var. nov. }\end{array}$ \\
\hline 56. & Homalium zeylanicum & Asteridiella homaligena \\
\hline 57. & Homonoia riparia & Meliola homonoiae \\
\hline 58. & Hovenia acerba & Meliola hoveniae \\
\hline 59. & Hovenia acerba & Meliola hoveniae \\
\hline 60. & Hugonia belli & Meliola hugoniae \\
\hline 61. & Ixora sp. & Asteridiella ixorae \\
\hline 62. & Jasminum brevilobum & Meliola daviesii \\
\hline 63. & Kamettia caryophyllata & Meliola kamettiae \\
\hline 64. & Kleinhovia hospita & Irenopsis kleinhoviae \\
\hline 65. & Knema attenuata & Meliola knemae \\
\hline 66. & Knoxia sp. & $\begin{array}{l}\text { Meliola kanniyakumariana var. } \\
\text { brahmagiriense }\end{array}$ \\
\hline 67. & Litsea sp. & $\begin{array}{l}\text { Meliola kakachiana var. } \\
\text { poochiparensis }\end{array}$ \\
\hline 68. & Litsea sp. & Meliola palakkadensis \\
\hline 69. & Lophopetalum wightiana & Meliola lophopetaligena \\
\hline 70. & Loranthus sp. & Irenopsis loranthicola \\
\hline 71. & Lucculia grandifolia & Meliola luculiae \\
\hline 72. & Luvunga sp. & Meliola luvungicola \\
\hline 73. & Meliaceae member & Meliola arkevermae \\
\hline 74. & Quirivelia frutescens & Meliola ichnocarpi-volubili \\
\hline 75. & Mesua ferrea & Meliola mesuae \\
\hline 76. & Michelia champaka & $\begin{array}{l}\text { Asteridiella micheliifolia nom. } \\
\text { nov. }\end{array}$ \\
\hline 77. & Michelia champaka & Meliola cariappae sp. nov. \\
\hline 78. & Myristica sp. & Meliola manoharacharyi \\
\hline 79. & Osyris arborea & Meliola mahamulkarii \\
\hline 80. & Otonephelium stipulaceum & Ectendomeliola otonephelii \\
\hline 81. & Ougeinia oojeinensis & Meliola ougeiniae \\
\hline 82. & Palaquium sp. & Amazonia palaquii \\
\hline 83. & Pavonia sp. & Irenopsis pavoniae \\
\hline 84. & Pittosporum neelgherrense & Asterediella pittosporacearum \\
\hline 85. & Pleurostylia sp & Meliola pleurostylicola \\
\hline 86. & Pogostemon travancoricus & Amazonia dikesinghii \\
\hline 87. & Premna glaberrima & Meliola premnigena \\
\hline
\end{tabular}




\begin{tabular}{|l|l|l|}
\hline 88. & Premna sp. & Asteridiella madikeriensis \\
\hline 89. & Pseudarthria viscida & $\begin{array}{l}\text { Meliola pseudarthriae var. } \\
\text { indica }\end{array}$ \\
\hline 90. & Psophocarpus tetragonolobus & Meliola psophocarpi \\
\hline 91. & Pterigota alata & Irenopsis pterigotae \\
\hline 92. & Pterygota alata & Meliola pterigotae \\
\hline 93. & Pycnospora lutescens & Meliola pycnosporae \\
\hline 94. & Rapanea sp. & Meliola rapaneae \\
\hline 95. & Salacia sp. & Meliola salaciicola \\
\hline 96. & Scolopia sp. & $\begin{array}{l}\text { Asteridiella scolopiae var. } \\
\text { indica }\end{array}$ \\
\hline 97. & Scutia myrtiana & Asteridiella emciciana \\
\hline 98. & Sebastiania chamaelea & Asteridiella sebastianiae \\
\hline 99. & Semecarpus travancorica & Meliola sanjappae \\
\hline 100. & Solanum verbasifolium & $\begin{array}{l}\text { Asteridiella winteri var. } \\
\text { macrospora }\end{array}$ \\
\hline 101. & Solanum viburnum & $\begin{array}{l}\text { Asteridiella solani var. } \\
\text { kodaikanalensis }\end{array}$ \\
\hline 102. & Symplocos macrophylla & $\begin{array}{l}\text { Asteridiella symploci- } \\
\text { microphyllae }\end{array}$ \\
\hline 103. & Sterculia sp. & Meliola sterculicola \\
\hline 104. & Streblu asper & Meliola strebli \\
\hline 105. & Streblus taxoides & Meliola strebli \\
\hline
\end{tabular}

\begin{tabular}{|c|c|c|}
\hline 106. & Strombosia ceylanica & $\begin{array}{l}\text { Meliola strombosiicola nom. } \\
\text { nov. }\end{array}$ \\
\hline 107. & Strombosia sp. & Meliola strombosiigena \\
\hline 108. & Strophathus wightianus & $\begin{array}{l}\text { Meliola strophanthicola var. } \\
\text { indica }\end{array}$ \\
\hline 109. & Symplocos anamallayana & Asteridiella kodaikanalensis \\
\hline 110. & Symplocos anamallayana & Asteridiella shenbaganurensis \\
\hline 111. & $\begin{array}{l}\text { Symplocos macrocarpa ssp. } \\
\text { kanarana }\end{array}$ & Meliola rachammae \\
\hline 112. & Syzygium sp. & Asteridiella brahmagiriensis \\
\hline 113. & Syzygium sp. & Meliola kukkeensis \\
\hline 114. & Toddalia asiatica & Asteridiella toddaliae \\
\hline 115. & Trichilia sp. & Irenopsis trichiliae \\
\hline 116. & Vaccinium griffithianum & Meliola shillongensis \\
\hline 117. & Vallaris solanacea & Meliola vallaridis \\
\hline 118. & Vitex leucoxylon & Meliola cookeana \\
\hline 119. & Vitex negundo & Asteridiella depokensis \\
\hline 120. & Vitex negundo & Asteridiella viticis-negundoi \\
\hline 121. & Wrightia tinctoria & $\begin{array}{l}\text { Meliola tabernaemontanae } \\
\text { var. wrightiae }\end{array}$ \\
\hline 122. & Xeromphis uliginosa & Irenopsis xeromphidis \\
\hline 123. & Zanthoxylum rhetsa & Meliola vatsavayae \\
\hline
\end{tabular}

